\title{
Coking Coal of the United States-Modern and Historical Coking Coal Mining Locations and Chemical, Rheological, Petrographic, and Other Data from Modern Samples
}

Open-File Report 2020-1113 



\section{Coking Coal of the United States- Modern and Historical Coking Coal Mining Locations and Chemical, Rheological, Petrographic, and Other Data from Modern Samples}

By Michael H. Trippi, Leslie F. Ruppert, Cortland F. Eble, and James C. Hower

Open-File Report 2020-1113 


\title{
U.S. Department of the Interior \\ DAVID BERNHARDT, Secretary
}

\author{
U.S. Geological Survey \\ James F. Reilly II, Director
}

U.S. Geological Survey, Reston, Virginia: 2021

For more information on the USGS - the Federal source for science about the Earth, its natural and living resources, natural hazards, and the environment—visit https://www.usgs.gov or call 1-888-ASK-USGS.

For an overview of USGS information products, including maps, imagery, and publications, visit https://store.usgs.gov/.

Any use of trade, firm, or product names is for descriptive purposes only and does not imply endorsement by the U.S. Government.

Although this information product, for the most part, is in the public domain, it also may contain copyrighted materials as noted in the text. Permission to reproduce copyrighted items must be secured from the copyright owner.

Suggested citation:

Trippi, M.H., Ruppert, L.F., Eble, C.F., and Hower, J.C., 2021, Coking coal of the United States-Modern and historical coking coal mining locations and chemical, rheological, petrographic, and other data from modern samples: U.S.

Geological Survey Open-File Report 2020-1113, 112 p., https://doi.org/10.3133/ofr20201113.

Associated data for this publication:

Trippi, M.H., Ruppert, L.F., Eble, C.F., and Hower, J.C., 2020, Coking coal of the United States-Modern and historical locations of coking coal mining locations and chemical, rheological, petrographic, and other data from modern samples: U.S. Geological Survey data release, at https://doi.org/10.5066/P9KF00KM.

ISSN 2331-1258 (online) 


\section{Acknowledgments}

The authors would like to thank Brian Cardott of the Oklahoma Geological Survey and Bill Prior of the Arkansas State Geological Survey for providing coal samples for analysis and inclusion in this report. We would also like to thank an anonymous mining company in Pennsylvania, Richard Kruse of ArcelorMittal USA in East Chicago, Indiana, and David Cork of Corky's Carbon Consultancy of Mayfield, New South Wales, Australia, for sharing data from analyses of coal samples in Pennsylvania, West Virginia, Virginia, and Kentucky. We are grateful to the following State geological survey and university personnel who provided much information about coking coal deposits and mining in their respective States: Paul Betka, David LePain, and James Clough from Alaska; John Bromley from Washington; Jay Gunderson from Montana; Chris Carroll from Wyoming; Brigitte Hucka and Jeff Quick from Utah; Peter Barkman and Chris Carroll from Colorado; Gretchen Hoffman from New Mexico; Brian Cardott from Oklahoma; Bill Prior and Ed Ratchford of Arkansas; Susan Rimmer from Illinois; Maria Mastalerz of Indiana; Ernie Slucher of the U.S. Geological Survey (USGS) and James McDonald of Ohio; Antonette Markowski of Pennsylvania; David Brezinski of Maryland; Mitch Blake of West Virginia; William Lassetter of Virginia; and Barry Miller of Tennessee. The authors thank Kevin DeVanney and Joseph Marquez of CoalTech Petrographic Associates, Inc., of Murrysville, Pennsylvnia, for their information and guidance with respect to the analyses of the coking coal samples. We acknowledge the following USGS scientists for their advice and information regarding chemical analyses and quality assurance of these analyses: John Sanfilipo (retired), Harvey Belkin (retired), Allan Kolker, and Nicholas Geboy (currently at the U.S. Department of State). Finally, we also would like to express our thanks for the instructive reviews by Brian Shaffer of the U.S. Geological Survey in Denver, Colorado, and John Popp, Geologist in Wilmore, Kentucky.

Ultimate and proximate analyses were provided by Geochemical Testing, Inc., of Somerset, Pennsylvania; major-, minor-, and trace-element data were provided by the Activation Laboratories of Ancaster, Ontario, Canada. Rheological analyses were provided by CoalTech Petrographic Associates, Inc., of Murrysville, Pennsylvania, and petrographic analyses were provided by the University of Kentucky petrography laboratory. Coal samples from Alabama and Kentucky were collected by Cortland Eble and James Hower of the Kentucky Geological Survey and the University of Kentucky Center for Applied Energy Research, respectively. 



\section{Contents}

Acknowledgments ….......................................................................................................................

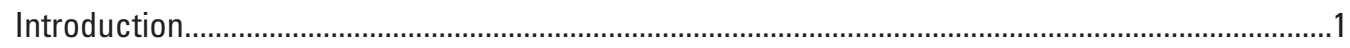

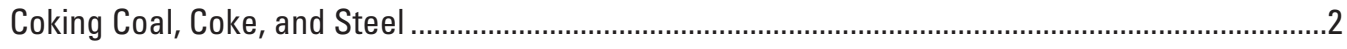

Chemical, Rheological, Petrographic, and Other Criteria for Evaluating Coking Potential

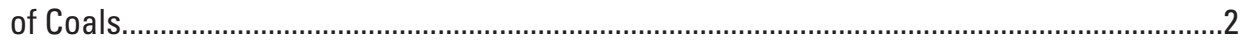

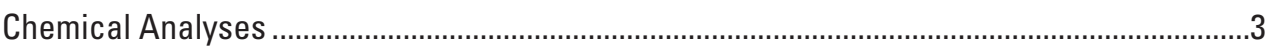

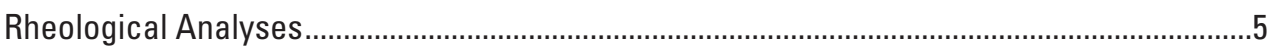

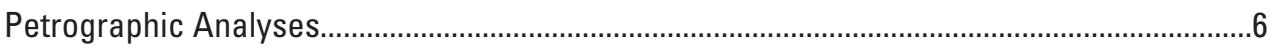

Miscellaneous Analyses.....................................................................................................

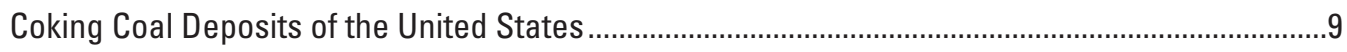

Coking Coal Deposits of the Western United States...............................................................

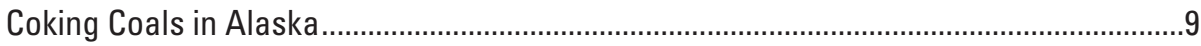

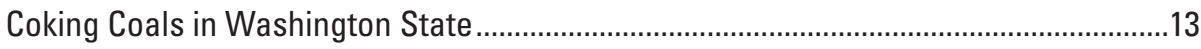

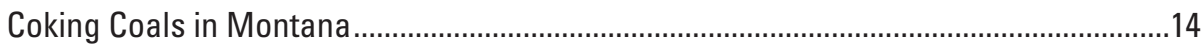

Coking Coals in Wyoming .....................................................................................16

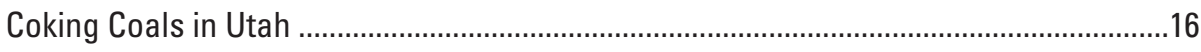

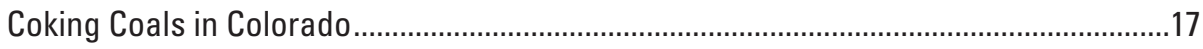

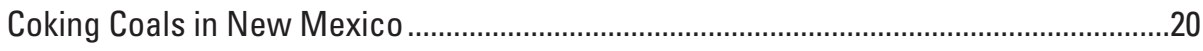

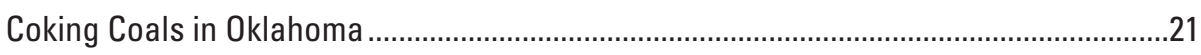

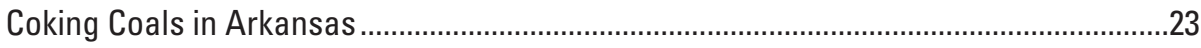

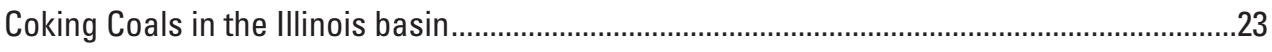

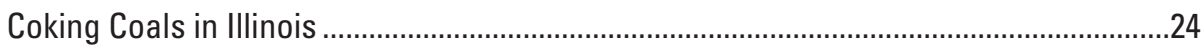

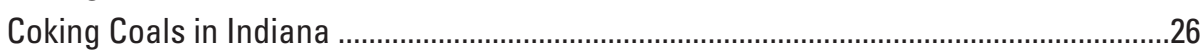

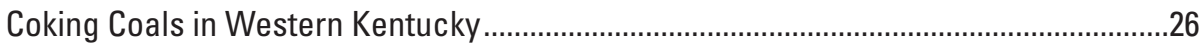

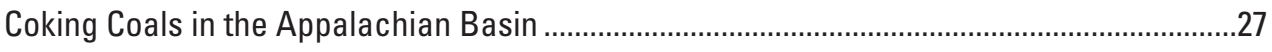

Coking Coals in the Northern Appalachian Basin Coal Region ......................................27

Washington (No. 12 in Ohio) coal bed ................................................................29

Waynesburg (No. 11 in Ohio) coal bed................................................................30

Sewickley (Meigs Creek or No. 9 in Ohio, Tyson in Maryland) coal bed..................30

Redstone (Pomeroy or No. 8A in Ohio) coal bed ..................................................31

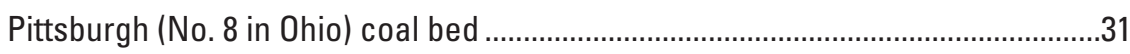

Barton (Elk Lick in Pennsylvania and West Virginia), Upper Bakerstown, Lower Bakerstown (Anderson in Ohio), and Mahoning (No. 7A in

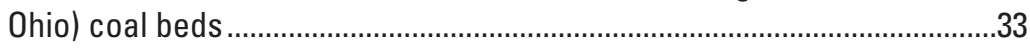

Upper Freeport (E in Pennsylvania; No. 7 in Ohio) coal bed .......................................

Lower Freeport ( $\mathrm{D}$ in Pennsylvania, No. 6A in Ohio) coal bed .................................35

Upper Kittanning ( $C^{\prime}$ in Pennsylvania) coal bed....................................................36

Middle Kittanning ( $C$ in Pennsylvania, No. 6 in Ohio) coal bed ...............................37

Lower Kittanning ( $\mathrm{B}$ in Pennsylvania, No. 5 in Ohio) coal bed ...............................37

Clarion ( $A^{\prime}$ in Pennsylvania, No. $4 A$ in Ohio) and Brookville ( $A$ in

Pennsylvania, Newland or No. 4 in Ohio) coal beds/zones.........................38

Pottsville Coking Coals.......................................................................................39

Coking Coals in the Central Appalachian Basin Coal Region........................................40

Coking Coals in Southern West Virginia ..............................................................40 


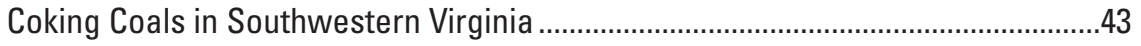

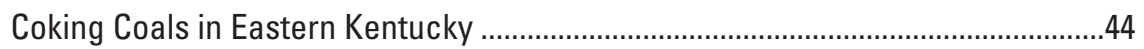

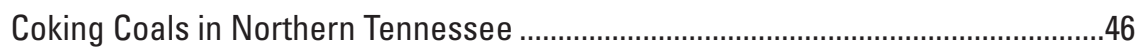

Coking Coals in the Southern Appalachian Basin Coal Region and Warrior

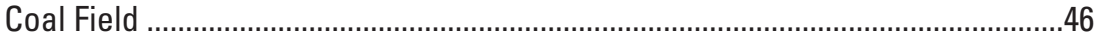

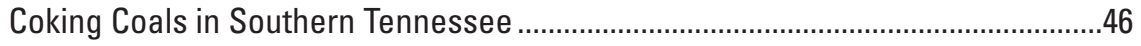

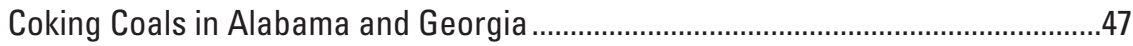

Coking Coals in the Warrior Coal Field in Alabama.............................................48

Coking Coals in the Plateau Coal Field in Alabama........................................49

Coking Coals in the Plateau Coal Field in Georgia ..........................................49

Coking Coals in the Cahaba Coal Field in Alabama........................................50

Coking Coals in the Coosa Coal Field in Alabama ..........................................50

Samples Collected and Analyzed for This Report ……….........................................................5

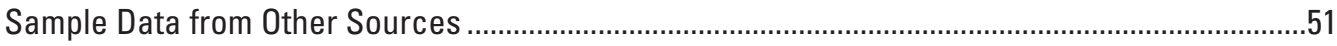

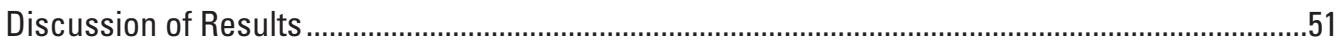

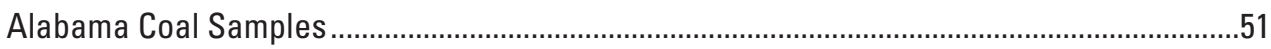

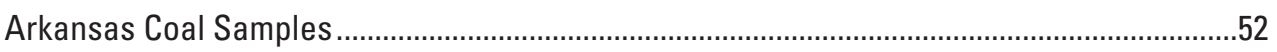

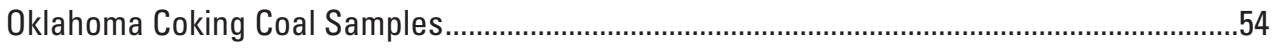

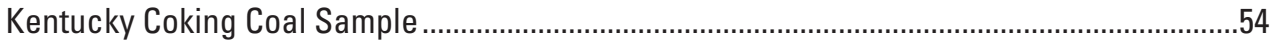

Pennsylvania data from an anonymous company ............................................................55

West Virginia data from ArcelorMittal .............................................................................55

West Virginia, Virginia, and Kentucky data from Corky's Carbon Consultancy.......................56

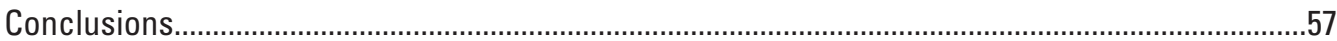

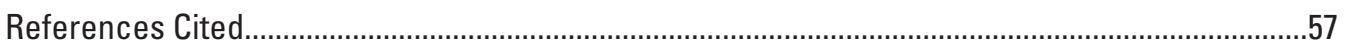

Appendix 1. Information About Coking Coal Deposits in the United States ................................75

Appendix 2. Location Data for Coal Samples Analyzed for this Report and Coal Sample

Data Shared by Mining Companies...................................................................................76

Appendix 3. Proximate and Ultimate Analysis Data for Coal Samples Analyzed for This

Report and Coal Sample Data Shared by Coal Mining Companies ......................................77

Appendix 4. Major Element Data for Ash Samples Analyzed for This Report and Ash

Sample Data Shared by Mining Companies .....................................................................78

Appendix 5. Minor and Trace Element Data for Coal Samples Analyzed for This Report and Coal Sample Data Shared by Mining Companies ......................................................79

Appendix 6. Rheological Data for Coal Samples Analyzed for This Report and Coal Sample Data Shared by Mining Companies

Appendix 7. Petrography Data for Coal Samples Analyzed for This Report and Coal

Sample Data Shared by Mining Companies ...................................................................81

Appendix 8. Miscellaneous Test Data for Coal Samples Shared by Mining Companies .............82

Appendix 9A. Thermal and (or) Coking Coal Production and the Number of Coal Mines by State, County, and Mine Type in 2017 .............................................................................83

Appendix 9B. Disposition of Thermal and (or) Coking Coal Beds by State in 2017 .......................84

Appendix 9C. Production and Bed Thickness of Several Major Thermal and (or) Coking Coal Beds by Mine Type in 2017

Appendix 10A. Production of Thermal and (or) Coking Coal in Western Kentucky by County in 2018

Appendix 10B. Production of Thermal and (or) Coking Coal in Western Kentucky by Mine Type in 2018 
Appendix 11A. Production of Bituminous Thermal and (or) Coking Coal in Pennsylvania

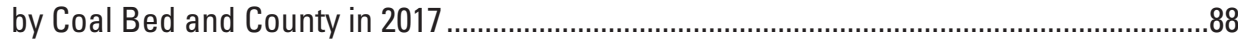

Appendix 11B. Number of Bituminous Thermal and (or) Coking Coal Mines in Pennsylvania by Coal Bed and County in 2017.

Appendix 11C. Underground Production of Bituminous Thermal and (or) Coking Coal in Pennsylvania by Coal Bed and County in 2017.

Appendix 11D. Number of Underground Bituminous Thermal and (or) Coking Coal Mines in Pennsylvania by Coal Bed and County in 2017.

Appendix 11E. Surface Production of Bituminous Thermal and (or) Coking Coal in Pennsylvania by Coal Bed and County in 2017.

Appendix 11F. Number of Surface Bituminous Thermal and (or) Coking Coal Mines in Pennsylvania by Coal Bed and County in 2017

Appendix 12. Production of Thermal and (or) Coking Coal in Ohio by County and Coal Bed in 2017

Appendix 13A. Production of Thermal and (or) Coking Coal in Maryland by Coal Bed and County in 2016.

Appendix 13B. Number of Thermal and (or) Coking Coal Mines in Maryland by Coal Bed and County in 2016.

Appendix 13C. Production from Underground and Surface Coal Mines in Maryland by County, Coal Bed, Operator, and Mine Permit Number in 2016

Appendix 14A. Production of Thermal and (or) Coking Coal in West Virginia by Coal Bed and County in 2017.

Appendix 14B. Number of Thermal and (or) Coking Coal Mines in West Virginia by Coal Bed and County in 2017.

Appendix 15A. Original Coal Resources in Eastern Kentucky, by Bed 100

Appendix 15B. Remaining Coal Resources in Eastern Kentucky in 2012, by Bed 101

Appendix 15C. Percentage of Original Coal Resources Remaining in Eastern Kentucky in 2012

Appendix 16A. Production of Thermal and (or) Coking Coal in Eastern Kentucky by County in 2018

Appendix 16B. Production of Thermal and (or) Coking Coal in Eastern Kentucky by Mine Type in 2018

Appendix 17A. Production of Thermal and (or) Coking Coal in Alabama by County and Mine Type During Fiscal Year 2017 (October 2016 to September 2017)

Appendix 17B. Number of Thermal and (or) Coking Coal Mines in Alabama by County and Mine Type During Fiscal Year 2017 (October 2016 to September 2017).....

Appendix 18. Historical Details of Pittsburgh Coal Bed Mining in the Connellsville and Klondike Coke Districts of Fayette County, Pennsylvania

Appendix 19. Historical Details of Lower Freeport Coal-Bed Mining in Indiana, Jefferson, and Fayette Counties, Pennsylvania

Appendix 20. Coal Purchased for Manufacturing of Coke in Pennsylvania by Coal Districts of Origin, From 1942 to 1965

Appendix 21. Origin of Coal Received by Oven-Coke Plants in Pennsylvania by Producing County, From 1966 to 1976 


\section{Figures}

1. Chart plotting the Strength Index against Compositional Balance Index, with isostability contours for the Stability Factor

2. Map of the United States showing the locations of coking coal mines and deposits west of the Mississippi River, and bituminous coal deposits in the Illinois and Appalachian basins

3. Map of a part of northwest Alaska showing the locations of coking coal deposits and the Corwin Formation bituminous coals near Cape Beaufort and the Kokolik and Kukpowruk Rivers

4. Map of a part of southern Alaska showing the locations of coking coal mines and deposits in the Lower Matanuska Valley and the Bering River coal field.

5. Map showing the locations of coking coal mines and deposits in the State of Washington

6. Map showing the locations of coking coal deposits in the States of Montana and Wyoming.

7. Map showing the locations of coking coal deposits in the States of Utah, Colorado, and New Mexico

8. Map showing the locations of bituminous coking coal deposits in the States of Oklahoma and Arkansas.

9. Map showing the locations of high-volatile, bituminous coal deposits in the States of Illinois, Indiana, and western Kentucky in the Illinois basin coal region

10. Map showing the locations of bituminous coal deposits in the States of Ohio, Pennsylvania, Maryland, and West Virginia in the Northern Appalachian basin coal region

11. Map showing the locations of bituminous coal deposits in the States of West Virginia, Virginia, eastern Kentucky, and Tennessee in the central Appalachian basin coal region

12. Map showing the locations of bituminous coal deposits in the States of Tennessee, Georgia, and Alabama in the Southern Appalachian basin coal region and the Warrior coal field

13. Photomicrographs of siderite infilling areas between coal macerals in samples from the Lower Hartshorne bed in Arkansas.

\section{Tables}

1. General quality ratings for washed, high-volatile, bituminous U.S. coking coal using 16 different properties

2. General quality ratings for washed, medium-volatile, bituminous U.S. coking coal using 16 different properties

3. General quality ratings for washed, low-volatile, bituminous U.S. coking coal using 16 different properties

4. List of the typical range of percentages for major element oxides in bituminous coals of the United States. 


\section{Conversion Factors}

International System of Units to U.S. customary units

\begin{tabular}{lcl}
\hline \multicolumn{1}{c}{ Multiply } & By & \multicolumn{1}{c}{ To obtain } \\
\hline meter $(\mathrm{m})$ & Length & \\
kilometer $(\mathrm{km})$ & 3.281 & foot $(\mathrm{ft})$ \\
meter $(\mathrm{m})$ & 0.6214 & mile $(\mathrm{mi})$ \\
\hline & 1.094 & yard (yd) \\
\hline tonne (t) (Metric ton) (2205 pounds) & Mass & \\
tonne (t) (Metric ton) (2205 pounds) & 1 & Megagram (Mg) \\
tonne ( $\mathrm{t})$ (Metric ton) (2205 pounds) & 0.9070 & ton, short (2,000 pounds) \\
\hline
\end{tabular}




\section{Abbreviations and Symbols}

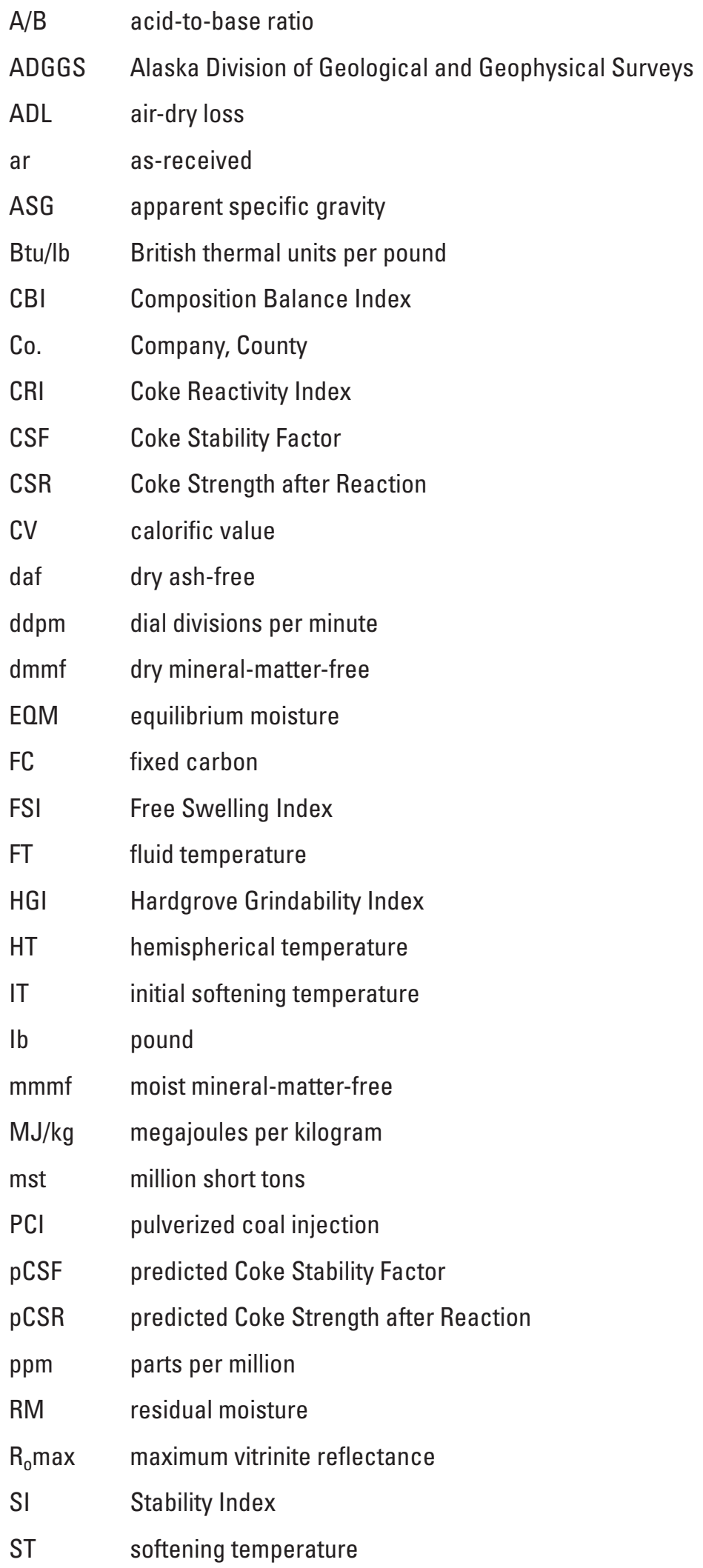




$\begin{array}{ll}\text { TSG } & \text { true specific gravity } \\ \text { tst } & \text { thousand short tons } \\ \text { USBM } & \text { U.S. Bureau of Mines } \\ \text { USGS } & \text { U.S. Geological Survey } \\ \text { VM } & \text { volatile matter } \\ \text { wt. } & \text { weight } \\ \% & \text { percent } \\ < & \text { less than } \\ \leq & \text { less than or equal to } \\ > & \text { greater than } \\ \geq & \text { greater than or equal to }\end{array}$





\title{
Coking Coal of the United States-Modern and Historical Coking Coal Mining Locations and Chemical, Rheological, Petrographic, and Other Data from Modern Samples
}

\author{
By Michael H. Trippi, ${ }^{1}$ Leslie F. Ruppert, ${ }^{1}$ Cortland F. Eble, ${ }^{2}$ and James C. Hower ${ }^{3}$
}

\section{Introduction}

Coking coal, or metallurgical coal, has been produced in the United States for nearly 200 years. Coking coal is primarily used in the production of coke for use in the steel industry, and for other uses (for example, foundries, blacksmithing, heating buildings, brewing). The United States exported a total of over 55 million short tons of coking coal to more than 37 countries around the world in 2017 (U.S. Energy Information Administration, 2018a). The United States ranked sixth in the world (after Australia, Indonesia, Russia, Colombia, and South Africa) in coking coal exports in 2016, and third in coking coal production (behind China and India) (International Energy Agency, 2017).

Currently, the majority of U.S. coking coal is produced in the Appalachian basin in the States of Alabama, Pennsylvania, West Virginia, and Virginia. Historically, Kentucky, Georgia, Maryland, Ohio, and Tennessee are other States in the Appalachian basin that have produced coking coal, but currently do not. All Appalachian and Illinois basin coking coals are Pennsylvanian in age. Illinois coals are generally not used alone as metallurgical coal but have been used in blends with Appalachian basin coals to make coke (Reed and others, 1952; Jackman and others, 1956; Jackman and others, 1959). Indiana coals of the Illinois basin may be used for pulverized coal injection (PCI) in steel mills but are not currently used alone as coking coals (Valia and Mastalerz, 2004). Western Kentucky coals of the Illinois basin were historically mined for coking, but currently are not. Coals from the western U.S. States of Arkansas, Oklahoma, New Mexico, Colorado, Utah, Wyoming, Montana, Washington, and Alaska were historically mined for coking, but in 2018 only Arkansas coals are mined for coking. Arkansas and Oklahoma coals are Pennsylvanian in age, while coals in New Mexico, Colorado, Utah, Wyoming, Montana, Washington, and Alaska range from Early Cretaceous through Eocene in age.

\footnotetext{
1U.S. Geological Survey

2Kentucky Geological Survey

${ }^{3}$ University of Kentucky Center for Applied Research.
}

Geographic Information System (GIS) data compiled for this project are available for download for public and private utilization and may be used to create maps for a variety of energy resource studies. The files were made by digitizing previously published maps created by State and Federal agencies, industry, and independent researchers. These GIS data are in shapefile format, and metadata files are included describing all GIS processing. These GIS data of the coking coal resources in the United States and the associated chemical and production data included in this product can provide researchers with a useful source of spatially-defined information for energy, economic, and other analyses.

Appendix 1 lists the names of coal basins, fields, regions, districts, and areas; coal beds or zones; geographic locations including States, counties, towns, rivers, mountains, etc.; stratigraphic hierarchy and age of the coal-bearing interval; coking characteristics including sulfur content, ash yield, volatile matter, moisture, calorific value, and Free-Swelling Index; coal rank; names of coal mines and coal-mining companies; current and past mining activity; and references for reports about the coal.

As a supplement to the GIS data, new coking coal samples from Alabama, Kentucky, Oklahoma (in cooperation with the Oklahoma Geological Survey) and Arkansas (in cooperation with the Arkansas Geological Survey) were collected and analyzed for proximate and ultimate analyses; calorific value; sulfur forms; major-, minor-, and trace-element abundances; free swelling indices; Gieseler Plastometer analyses; American Society for Testing and Materials (ASTM) dilatation; and coal petrography. These new analyses are included in appendixes 2 to 8 . These data can also be downloaded from https://doi.org/ 10.5066/P9KFQOKM. Coal Stability Factor and Coal Strength after Reaction with $\mathrm{CO}_{2}(\mathrm{CSF})$ were predicted using chemical, rheological, and petrographic data. In addition, data from previously analyzed samples in Pennsylvania, West Virginia, Virginia, and Kentucky were shared with us by an anonymous mining company, ArcelorMittal, and Corky's Carbon Consultancy (appendixes 2 to 8). These data include results from all the tests listed above, plus oxidation, Hardgrove Grindability Index (HGI), and ash fusion (in a reducing environment) temperatures (appendix 8). These data can also be downloaded from https://doi.org/10.5066/P9KFQOKM. 


\section{Coking Coal, Coke, and Steel}

Coke, a hard porous solid that is high in carbon and low in impurities, is used in blast furnaces in the steel making industry. Coke performs several functions in the blast furnace including: (1) providing heat to make molten iron; (2) providing carbon to make carbon monoxide for the reduction of the iron ore to metallic iron, and; (3) providing structural support for the "charge" (iron ore, limestone, and coal) in the blast furnace (Holway, 1975). The coke must also be porous to allow hot air and carbon monoxide to pass through the blast furnace evenly (Holway, 1975). Limestone is used in the blast furnace as a fluxing agent to remove sulfur from the coke (Holway, 1975).

Coke is produced by heating metallurgical coal to temperatures of 1000 to $1100{ }^{\circ} \mathrm{C}$ in a reducing environment for 12 to 36 hours (Holway, 1975; World Coal Association, 2018). Today most coke is made in large by-product coke ovens and coke batteries (a series of adjacent by-product ovens). By-products of the coking process like tar, ammonia liquor, ammonium sulfate, light oils, and coke oven gas are recovered and processed in an adjacent chemical plant (Sundholm and others, 1999). Benzene, toluene, xylene, and solvent naphthas can be recovered from light oils, and acetylene, ammonia, carbon dioxide, carbon monoxide, ethane, ethylene, hydrogen, hydrogen sulfide, methane, nitrogen, and oxygen can be recovered from coke oven gas (Sundholm and others, 1999). In the 21st century, the use of heat-recovery and non-recovery ovens is becoming more common (Sundholm and others, 1999; Kramer and others, 2011; Valia, 2019). In non-recovery ovens, air is introduced in the oven above the coke bed and volatile gases are combusted, thus eliminating potential atmospheric pollutants (Kramer and others, 2011; Valia, 2019). In heat-recovery ovens, hot oven gases are used to produce steam to drive turbines and generate electricity (Sundholm and others, 1999; Kramer and others, 2011; Valia, 2019). In 2016 , there were heat-recovery ovens at five of the 16 operating coke plants in the United States (American Coke and Coal Chemicals Institute, 2018). In the late 19th and early 20th centuries, coke was more commonly made in smaller domeshaped "beehive" ovens. During carbonization the coal liquefies and loses most of its volatile matter, then solidifies into a hard porous high-carbon solid. After cooling, the oven doors are opened, and the coke is pushed into quench cars, which are then moved to a quench station where the coke is quenched in water or nitrogen (Towsey and others, 2011).

\section{Chemical, Rheological, Petrographic, and Other Criteria for Evaluating Coking Potential of Coals}

Coals that are satisfactory for making coke, known as coking coals (or metallurgical coals), exhibit certain characteristics that may not be present in steam (or thermal) coal, including the following: (1) high carbon content, (2) low sulfur content, (3) low ash yield, (4) low phosphorus content, (5) the ability to form a porous hard solid (or to "cake") during carbonization, and (6) the tendency to shrink (or, at least, to not expand) in size during carbonization (Jackman and Helfinstine, 1967; Sweet, 1969; Holway, 1975; World Coal Association, 2018). The evaluation of a coal to determine its suitability for the production of metallurgical coke involves a number of chemical, rheological, petrographic, and other analyses. Quite often a coal may be considered acceptable for coking based on a particular analysis or test, while another test indicates unsuitability for coking. For this reason, two or more different coals are blended to create a final product that is suitable for coking using coals with offsetting properties to achieve an end-product that meets the blend targets. Although it is possible for a single coal to be used to create a good metallurgical coke, it is rare to find a coal that meets all criteria for a satisfactory coking coal. Currently coal blends typically contain more high-volatile bituminous coal with lesser amounts of medium- and low-volatile coal (Kevin DeVanney, CoalTech Petrographic Associates, Inc., oral commun., 2018). This report does not attempt to describe methodologies that may be used to properly blend coals for a desired final product. The following publications summarize methodologies used for blending coals: Dutcher and Crelling (2000); Spackman (2000); Thompson (2000); and Diez and others (2002).

Details of the results of analytical data run on samples collected for this report and data shared by three mining companies can be found in the sections entitled "Samples Collected and Analyzed for This Report," "Sample Data From Other Sources," and "Discussion of Results." These data are included in appendixes 2 to 8 . These data can also be downloaded from https://doi.org/10.5066/P9KFQOKM.

Tables 1, 2, and 3 summarize poor to marginal, good to fair, and very good to excellent value ranges for 16 properties for washed high-, medium-, and low-volatile bituminous U.S. coking coals, respectively (DeVanney and Mitchell, 2015). These tables were provided to us by Kevin DeVanney of Coal Tech Petrographic Associates, Inc., of Murrysville, Pennsylvania, and are shared here for use as general guidelines. The value ranges shown in tables 1 to 3 are approximate and have not been verified or approved by the U.S. Geological Survey (USGS), ASTM, or any other organization, and should only be used for qualitative discussions of the coal properties presented in these tables. Furthermore, neither the United States Government, nor the USGS, nor any of their employees, makes any warranty, expressed or implied, or assumes any legal liability or responsibility for the accuracy, completeness, or usefulness of any information included in tables 1 to 3 . The act of distribution shall not constitute any such warranty, and no responsibility is assumed by the USGS in the use of the information in tables 1 to 3. Kevin DeVanney of CoalTech Petrographic Associates, Inc. (written commun., 2016) stated "the met coal rating tables are based on my personal experience and correspondence with U.S.A. coke makers and coal producers. They are subject to change from time to time 
depending on market conditions and are only applicable to U.S.A. coals and coke plants. They are less applicable to heat recovery batteries and are generally not applicable to most export shipment quality or international usage. Since these are based on "opinion" they should be used as guidelines only.

Exceptions always exist."

It should also be noted that tables 1 to 3 were intended for use only with washed U.S. coals. It is also important to remember that nearly all coals used in cokemaking today are blended with other coals to produce an end-product that meets the needs of the coke plant with respect to multiple coal properties. Any sample of a single coal bed (as the samples collected for this study are) will almost certainly not be used by itself to make coke.

\section{Chemical Analyses}

Several coal chemistry analyses are useful for evaluating the coking potential of coals including the percentages of volatile matter (VM), ash yield, sulfur content, and phosphorus pentoxide $\left(\mathrm{P}_{2} \mathrm{O}_{5}\right)$ content in the ash, and the acid-to-base ratio in ash. Proximate analysis (following the American Society for Testing and Materials [ASTM] standard D3172) determines the percentages of moisture, ash, VM, and fixed carbon (FC) in the coal (FC is determined by subtracting the sum of moisture, ash, and VM from 100). VM and calorific value (CV) (or heating value, in Btu/lb) of the coal (as determined by ASTM standard D5865) are used to determine the coal's rank (using ASTM standard D388).

On a dry, ash-free basis (daf) the percentages of VM and $\mathrm{FC}$ in coal sum to 100 percent, and therefore they are inversely proportional to each other. VM and FC are related to coal rank. According to ASTM standard D388, low-volatile bituminous coal has a VM value of 14 to 22 percent, mediumvolatile bituminous coal has a VM value of 22 to 31 percent, and high-volatile bituminous coal has a VM value greater than 31 percent on a dry, mineral-matter-free basis (dmmf). High carbon in a coking coal increases the coke yield (the ratio of coking coal to coke produced, expressed as a percentage) (Holway, 1975), so low percentages of VM also indicate higher coke yield. But "low" has a different meaning for the different ranks of bituminous coal. The following VM ranges are considered very good to excellent for washed bituminous U.S. coals: 31 to 34 percent, 23 to 28 percent, and $>18$ to $<21$ percent, for high-, medium-, and low-volatile ranks, respectively (tables 1 to 3 ). Poor to good VM percent ranges for washed bituminous U.S. coals are also shown in tables 1 to 3 .

Ash yield is another important parameter used to evaluate the coking potential of coals. Ash yield is a measure of the impurities in the coal, and it is therefore desirable for the ash yield to be low. Ash yields that are less than six percent are

Table 1. General quality ratings for washed, high-volatile, bituminous U.S. coking coal using 16 different properties (DeVanney and Mitchell, 2015).

[Abbreviations and symbols: A/B, acid-to-base ratio; ${ }^{\circ} \mathrm{C}$, degrees Celsius; CSR, Coke Strength after Reaction; daf, dry ash-free basis; ddpm, dial divisions per minute; ${ }^{\circ}$ F, degrees Fahrenheit; FSI, Free Swelling Index; HGI, Hardgrove Grindability Index; max., maximum; red., reducing environment; $\mathrm{R}_{0}$ max, maximum vitrinite reflectance in oil; ST, softening temperature; VM, volatile matter; $\%$, percent; >, greater than; $\geq$, greater than or equal to; $<$, less than; $\leq$, less than or equal to. Note that these data are not applicable to unwashed coal or coal for use outside of the United States.]

\begin{tabular}{|c|c|c|c|}
\hline Property & Poor to marginal & Fair to good & Very good to excellent \\
\hline VM (\%, daf $)$ & $\geq 40$ & $>34$ and $<40$ & $31-34$ \\
\hline Ash (\%, dry) & $>8$ & $>6$ and $<8$ & $<6$ \\
\hline Oxidation (\%) & $<87$ & $>87$ and $<94$ & $\geq 94$ \\
\hline FSI & $<6$ & $>6$ and $<8$ & $>8$ \\
\hline Dilatation (\%) & $<100$ & $>100$ and $<180$ & $\geq 180$ \\
\hline Sole-heated oven $(\%)$ & $>-12$ & $-12--20$ & $<-20$ \\
\hline HGI & $<42$ or $>80$ & $\geq 42$ and $<55$ & $>55$ and $<80$ \\
\hline Ash fusion ST ( ${ }^{\circ} \mathrm{F}$, red.) & $\leq 2,250$ & $>2,250$ and $\leq 2,575$ & $>2,575$ \\
\hline Inert content $(\%)$ & $<15$ or $>35$ & $15-20$ or $30-35$ & $>20$ and $<30$ \\
\hline $\operatorname{CSR}(\%)$ & $<45$ & $\geq 45$ and $\leq 56$ & $>56$ \\
\hline
\end{tabular}


Table 2. General quality ratings for washed, medium-volatile, bituminous U.S. coking coal using 16 different properties (DeVanney and Mitchell, 2015).

[Abbreviations and symbols: \%, percent; >, greater than; $\geq$, greater than or equal to; <, less than; $\leq$, less than or equal to; A/B, acid-to-base ratio; ${ }^{\circ} \mathrm{C}$, degrees Celsius; CSR, Coke Strength after Reaction; daf, dry ash-free basis; ddpm, dial divisions per minute; ${ }^{\circ}$ F, degrees Fahrenheit; FSI, Free Swelling Index; HGI, Hardgrove Grindability Index; max., maximum; red., reducing environment; $\mathrm{R}_{\mathrm{o}} \mathrm{max}$, maximum vitrinite reflectance in oil; n/a, not applicable; ST, softening temperature; VM, volatile matter. Note that these data are not applicable to unwashed coal or coal for use outside of the United States.]

\begin{tabular}{lccc}
\hline \multicolumn{1}{c}{ Property } & Poor to marginal & Fair to good & Very good to excellent \\
\hline $\mathrm{VM}(\%$, daf) & $\mathrm{n} / \mathrm{a}$ & $<23$ or $>28$ & $23-28$ \\
Ash $(\%$, dry) & $\geq 8$ & $>6$ and $<8$ & $<6$ \\
Sulfur $(\%$, dry) & $\geq 1.3$ & $>0.8$ and $<1.3$ & $<0.8$ \\
Oxidation (\%) & $<90$ & $90-97$ & $>97$ \\
FSI & $<7$ & $>7$ and $<8$ & $>8$ \\
Max. fluidity $(\mathrm{ddpm})$ & $\leq 150$ & $200-1,000$ & $>1,000$ \\
Plastic range $\left({ }^{\circ} \mathrm{C}\right)$ & $\leq 50$ & $>50$ and $<80$ & $>80$ \\
Dilatation $(\%)$ & $<100$ & +30 and $<200$ & $\geq 200$ \\
Sole-heated oven $(\%)$ & $>+4$ & $50-60$ or $90-100$ & $<-3$ \\
HGI & $<50$ or $>100$ & $>2,250$ and $<2,575$ & $>60$ and $<90$ \\
Ash fusion ST $\left({ }^{\circ} \mathrm{F}\right.$, red.) & $\leq 2,250$ & $>3.5$ and $<6.0$ & $>2,575$ \\
Ash A/B ratio & $<3.5$ & $>0.5$ and $<1.2$ & $>6.0$ \\
$\mathrm{P}_{2} \mathrm{O}_{5}$ in the ash $(\%)$ & $<1.20$ or $>1.40$ & $<0.5$ \\
Mean $\mathrm{R}_{\mathrm{0}}$ max $(\%)$ & $\mathrm{n} / \mathrm{a}$ & $15-20$ or $30-35$ & $1.20-1.40$ \\
Inert content $(\%)$ & $<15$ or $>35$ & $>50$ and $<60$ & $>20$ and $<30$ \\
CSR $(\%)$ & $\leq 50$ & & $>60$ \\
\hline
\end{tabular}

Table 3. General quality ratings for washed, low-volatile, bituminous U.S. coking coal using 16 different properties (DeVanney and Mitchell, 2015).

[Abbreviations: \%, percent; >, greater than; $\geq$, greater than or equal to; $<$, less than; $\leq$, less than or equal to; $\mathrm{A} / \mathrm{B}$, acid-to-base ratio; ${ }^{\circ} \mathrm{C}$, degrees Celsius; CSR, Coke Strength after Reaction; daf, dry ash-free basis; ddpm, dial divisions per minute; ${ }^{\circ}$, degrees Fahrenheit; FSI, Free Swelling Index; HGI, Hardgrove Grindability Index; max., maximum; red., reducing environment; $\mathrm{R}_{0} \max$, maximum vitrinite reflectance in oil; ST, softening temperature; VM, volatile matter. Note that these data are not applicable to unwashed coal or coal for use outside of the United States.]

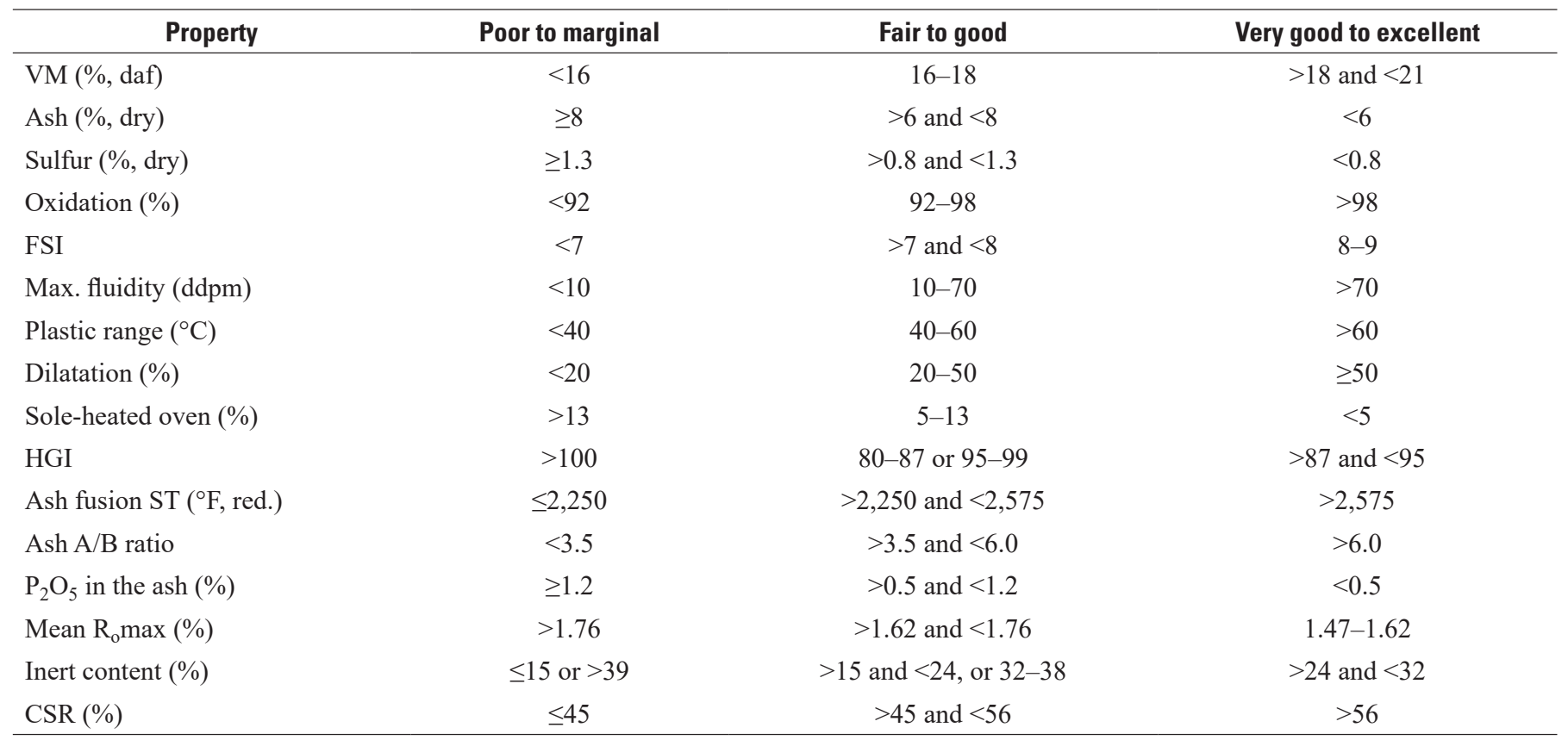


considered very good to excellent for washed U.S. bituminous coals (tables 1 to 3). Poor to good ash yields for washed bituminous U.S. coals are also shown in tables 1 to 3.

Ultimate analysis (following ASTM standard D3176) determines the percentages of hydrogen $(\mathrm{H})$, carbon $(\mathrm{C})$, nitrogen $(\mathrm{N})$, sulfur $(\mathrm{S})$, and oxygen $(\mathrm{O})$ in the coal (the percentage of $\mathrm{O}$ is calculated by subtracting the sum of the percentages of $\mathrm{H}, \mathrm{C}, \mathrm{N}, \mathrm{S}$, and ash from 100). Of these elements, sulfur is very important in the evaluation of coals for coking potential. High sulfur content in steel leads to brittleness, so more limestone is needed when higher sulfur coals are used in the blast furnace (Holway, 1975). For washed U.S. bituminous coals, sulfur contents less than 0.8 percent are considered very good to excellent (tables 1 to 3). Poor to good sulfur contents for washed bituminous U.S. coals are also shown in tables 1 to 3. It is also important to determine the amounts of sulfate, organic, and pyritic sulfur in the coal (following ASTM standard D2492). The washing process may only remove approximately 50 percent of pyritic sulfur, so for coals in which non-pyritic forms of sulfur make up the majority of sulfur in the coal, washing may be ineffective to bring the coal within acceptable limits (Brian Shaffer, U.S. Geological Survey, written commun., 2019).

Phosphorus is also undesirable in the making of metallurgical coke and should be kept to a minimum in coking coals (Diez and others, 2002). The determination of phosphorus pentoxide $\left(\mathrm{P}_{2} \mathrm{O}_{5}\right)$ content in the ash is therefore important in evaluating coking coal. For washed U.S. bituminous coals, $\mathrm{P}_{2} \mathrm{O}_{5}$ contents in the ash of less than or equal to 0.5 percent are considered very good to excellent (tables 1 to 3 ). Poor to good $\mathrm{P}_{2} \mathrm{O}_{5}$ contents in ash from washed bituminous U.S. coals are also shown in tables 1 to 3 .

Major element contents of coal ash $\left(\mathrm{SiO}_{2}, \mathrm{Al}_{2} \mathrm{O}_{3}, \mathrm{Fe}_{2} \mathrm{O}_{3}\right.$, $\mathrm{TiO}_{2}, \mathrm{CaO}, \mathrm{MgO}, \mathrm{Na}_{2} \mathrm{O}$, and $\mathrm{K}_{2} \mathrm{O}$, expressed as percentages on a dry basis) can be used to calculate the acid-to-base ratio $(\mathrm{A} / \mathrm{B})$ in ash using the following equation:

$$
\begin{gathered}
\mathrm{A} / \mathrm{B}=\left(\mathrm{SiO}_{2}+\mathrm{Al}_{2} \mathrm{O}_{3}+\mathrm{TiO}_{2}\right) /\left(\mathrm{Fe}_{2} \mathrm{O}_{3}+\mathrm{CaO}+\mathrm{MgO}+\right. \\
\left.\mathrm{K}_{2} \mathrm{O}+\mathrm{Na}_{2} \mathrm{O}\right)
\end{gathered}
$$

High percentages of acidic components and low percentages of basic components reduce oven wall reactions with ash and coke (DeVanney and Mitchell, 2015). For washed U.S. bituminous coals, A/Bs greater than or equal to 6.0 are considered very good to excellent (tables 1 to 3 ). Poor to good ash $\mathrm{A} / \mathrm{Bs}$ for washed bituminous U.S. coals are also shown in tables 1 to 3 .

\section{Rheological Analyses}

Several rheological tests are used to evaluate the coking potential of coals including the Free-Swelling Index (FSI), the Gieseler Plastometer test, and the ASTM dilatation test, among others. If thermoplastic properties are not present, coals are considered non-coking.
The Free-Swelling Index (as determined by ASTM standard D720) is used to determine if a coal will soften, swell, and resolidify into a porous mass (or "cake") during heating, a very important transformation that takes place in coking coals. A one-gram (g) sample of coal that has passed a 250 -micrometer $(\mu \mathrm{m})$ (No. 60) sieve (-250- $\mu \mathrm{m}$ [-No. 60] coal) is placed in a crucible and heated to a temperature of 800 to $820^{\circ} \mathrm{C}$ until a "coke button" forms. The shape of the button is compared to standard profiles of coke buttons (see fig. 4 in ASTM standard D720) and assigned a numeric value between 0 and 9. Coals with a high FSI value (greater than 7) have good coking potential, while coals with an FSI value below 3.5 are considered to have no coking potential (Zimmerman, 1979). FSI values of 8 to 9 are considered an indication of very good to excellent coking ability for washed U.S. bituminous coals (tables 1 to 3). Poor to good FSI ranges for washed bituminous U.S. coals are also shown in tables 1 to 3 .

The Gieseler Plastometer test (following ASTM standard D2639) is a semi-quantitative test of the plastic property of a coal when it is heated in the absence of air. The resistance of the coal in a crucible to the rotational movement of a "stirrer" is measured as the crucible is heated at a prescribed rate. As the coal softens the stirrer encounters less resistance and begins to move faster. However, after a certain temperature the liquified coal begins to solidify and the stirrer slows down and eventually stops. Two important values are determined during the Gieseler Plastometer test: (1) the maximum speed attained by the stirrer (or the maximum fluidity), and (2) the difference between the initial softening temperature and the solidification temperature (or the plastic range). In general, coals with "high" values for both properties have good coking potential, but the meaning of "high" varies greatly for each coal rank. Maximum fluidity values greater than or equal to 20,000 dial divisions per minute (ddpm), greater than $1,000 \mathrm{ddpm}$, and greater than $70 \mathrm{ddpm}$ are considered very good to excellent for washed high-, medium-, and low-volatile bituminous U.S. coals, respectively (tables 1 to 3). Plastic ranges greater than or equal to 95 , greater than 80 , and greater than $60^{\circ} \mathrm{C}$ for washed high-, medium-, and low-volatile bituminous U.S. coals, respectively, are considered very good to excellent (tables 1 to 3). Poor to good maximum fluidity and plastic ranges for washed bituminous U.S. coals are also shown in tables 1 to 3 .

The ASTM dilatation test (similar to Audibert-Arnu dilatation, but following ASTM standard D5515) is another test that measures the swelling ability of coals. A "pencil" made of $-250-\mu \mathrm{m}$ (-No. 60) coal is placed in a tube in the dilatometer apparatus and is heated at a prescribed rate while a steel rod resting on top of the coal moves up and down indicating changes in volume as the coal liquifies and shrinks, then expands and solidifies. The maximum percentage of expansion expressed as a percentage of the initial 60 millimeter $(\mathrm{mm})$ length of the coal pencil is called the "dilatation." Depending on rank, "high" dilatation percentages are considered desirable for good coking potential. Dilatation percentages greater than 
or equal to 180 percent, greater than or equal to 200 percent, and greater than or equal to 50 percent are considered very good to excellent for washed high-, medium-, and low-volatile bituminous U.S. coals, respectively (tables 1 to 3). Poor to good dilatation ranges for washed bituminous U.S. coals are also shown in tables 1 to 3 .

The sole-heated oven test (ASTM standard D-2014) measures the expansion or contraction of coals during carbonization in an oven to a temperature of $554^{\circ} \mathrm{F}$ (Zimmerman, 1979; ASTM standard D-2014). This test is important for the evaluation of coals that are to be coked in by-product ovens, which can be damaged by highly expansive coals. The percentage of expansion is calculated by the following equation:

$$
\text { Percentage of expansion }=100\left(\mathrm{~h}_{\mathrm{i}}-\mathrm{h}_{\mathrm{f}}\right) / \mathrm{h}_{\mathrm{f}}
$$

where $h_{i}$ is the initial thickness of the coal, and $h_{f}$ is the final thickness of the coke made during the test (ASTM standard D-2014). Positive values indicate that expansion has occurred during carbonization, while negative values indicate contraction. In general, "low" percentages are considered desirable, but the meaning of "low" varies greatly for each coal rank. For washed high-volatile bituminous U.S. coals, percentages less than -20 percent are considered very good to excellent, while percentages less than -3 percent and less than 5 percent are considered very good to excellent for washed medium and low-volatile bituminous U.S. coals, respectively (tables 1 to 3). Poor to good percentages of expansion for washed bituminous U.S. coals are also shown in tables 1 to 3. Most coal blends contain a mixture of expanding and contracting coals that aim for 8 to 12 percent contraction (Kevin DeVanney, CoalTech Petrographic Associates, Inc., oral commun., 2018). Note that damage caused by expansion is only an issue in by-product slot ovens, so this test is of no importance for coals that will be coked in heat-recovery (or non-recovery) and beehive ovens.

\section{Petrographic Analyses}

Coal petrography is one of the most important methods used to evaluate the coking potential of coals. Industrial application of coal petrographic analysis has been used for decades to select coals for coking and for making coal blends. Several petrographic properties including vitrinite reflectance, percentage of inert coal components (see definition) in the coal, and predicted Coke Stability Factor (pCSF) are essential for evaluating coals for coking potential.

Vitrinite reflectance (determined by ASTM standard D2798), an important method in estimating the maximum temperature history of sediments, can be used for evaluating the coking potential of bituminous coals. Davis (1978) provided the following mean maximum vitrinite reflectance in oil $\left(\mathrm{R}_{\mathrm{o}} \mathrm{max}\right)$ ranges for bituminous coal ranks: 0.47 to 1.10 percent for high-volatile bituminous, 1.10 to 1.50 percent for medium-volatile bituminous, and 1.50 to 2.05 percent for low-volatile bituminous. Mean $\mathrm{R}_{0} \max$ values greater than 0.98 percent, 1.20 to 1.40 percent, and 1.47 to 1.62 percent are considered an indication of very good to excellent coking potential for washed high-, medium-, and low-volatile bituminous U.S. coals, respectively (tables 1 to 3). Poor to good mean $\mathrm{R}_{\mathrm{o}}$ max percentages for washed bituminous U.S. coals are also shown in tables 1 to 3 .

The percentage of inert coal components (or "inerts") is another important parameter used to evaluate coking potential of coals. Total inerts is the sum of the percentage of inertinite macerals, two-thirds of the percentage of semifusinite, and the percentage of mineral matter in the coal (Schapiro and others, 1961). Coal maceral analysis is conducted using method ASTM standard D2799. For washed, high- and mediumvolatile bituminous U.S. coals, inert percentages of $>20$ and $<30$ percent are considered very good to excellent. For washed low-volatile bituminous U.S. coals, inert percentages of $>24$ and $<32$ percent are considered very good to excellent. Poor to good inert percentages by rank for washed bituminous U.S. coals are also shown in tables 1 to 3.

Various mathematical calculations using data from petrographic analyses of coals have been developed to predict properties of coke made from those coals (Mackowsky, 1977). One of these properties is the Coke Stability Factor (CSF), which is determined using the ASTM tumbler test for coke (ASTM standard D3402). The CSF is a measure of the resistance of a coke to degradation caused by impact and abrasion during removal from coke ovens, transportation, and during its descent inside a blast furnace. The test procedure, as it is performed on coke samples in a lab, is described in the following section entitled "Miscellaneous Analyses." However, the value of CSF is often predicted using calculations based on petrographic data as developed by U.S. Steel (Schapiro and others, 1961; Schapiro and Gray, 1964). This method assumes that (1) an optimal mix of reactive and inert components in a given coal or coal blend will produce a coke with the most desirable characteristics, and (2) the optimum ratio of reactive and inert components varies with the rank of the coal or coal blend. This concept has been compared to the preparation of concrete whereby the reactive components in the coal act as the binder or cement, and the inert components represent sand and (or) gravel. Two properties, the Stability Index (SI) and Composition Balance Index (CBI), are calculated from percentages of reactive and inert components, then plotted on a chart with CSF isostability lines (fig. 1). In this study, we applied the U.S. Steel method to the predicted Coke Stability Factor (pCSF) for samples that we collected for this project and coal data shared with us from two coal mining companies (Corky's Carbon Consultancy and an anonymous coal company). Values of CBI, SI, and pCSF are shown in appendix 7 and discussed in the "Discussion of Results" section. These data can also be downloaded from https://doi.org/10.5066/ P9KFQOKM. 


\section{Miscellaneous Analyses}

Several other tests can be used for evaluation of coals for coking potential including the oxidation test, the Hardgrove Grindability Index (HGI), ash-fusion temperatures, the Coke Stability Factor (CSF), Coke Hardness Factor (CHF), Coke Reactivity Index (CRI), Coke Strength after Reaction with $\mathrm{CO}_{2}$ (CSR), and predicted Coke Strength after Reaction with $\mathrm{CO}_{2}$ (pCSR).
The alkali-extraction (or oxidation) test is used to estimate the amount of oxidation that has occurred in the coal (Lowenhaupt and Gray, 1980). A coal sample is boiled in a caustic solution that dissolves the oxidized coal, which darkens the solution (ASTM standard D5263). The percentage of light transmittance through the solution is then measured. "Low" transmittance values indicate significant oxidation of the coal, which should not be used for making metallurgical coke (the definition of "low" depends on rank). Percentages

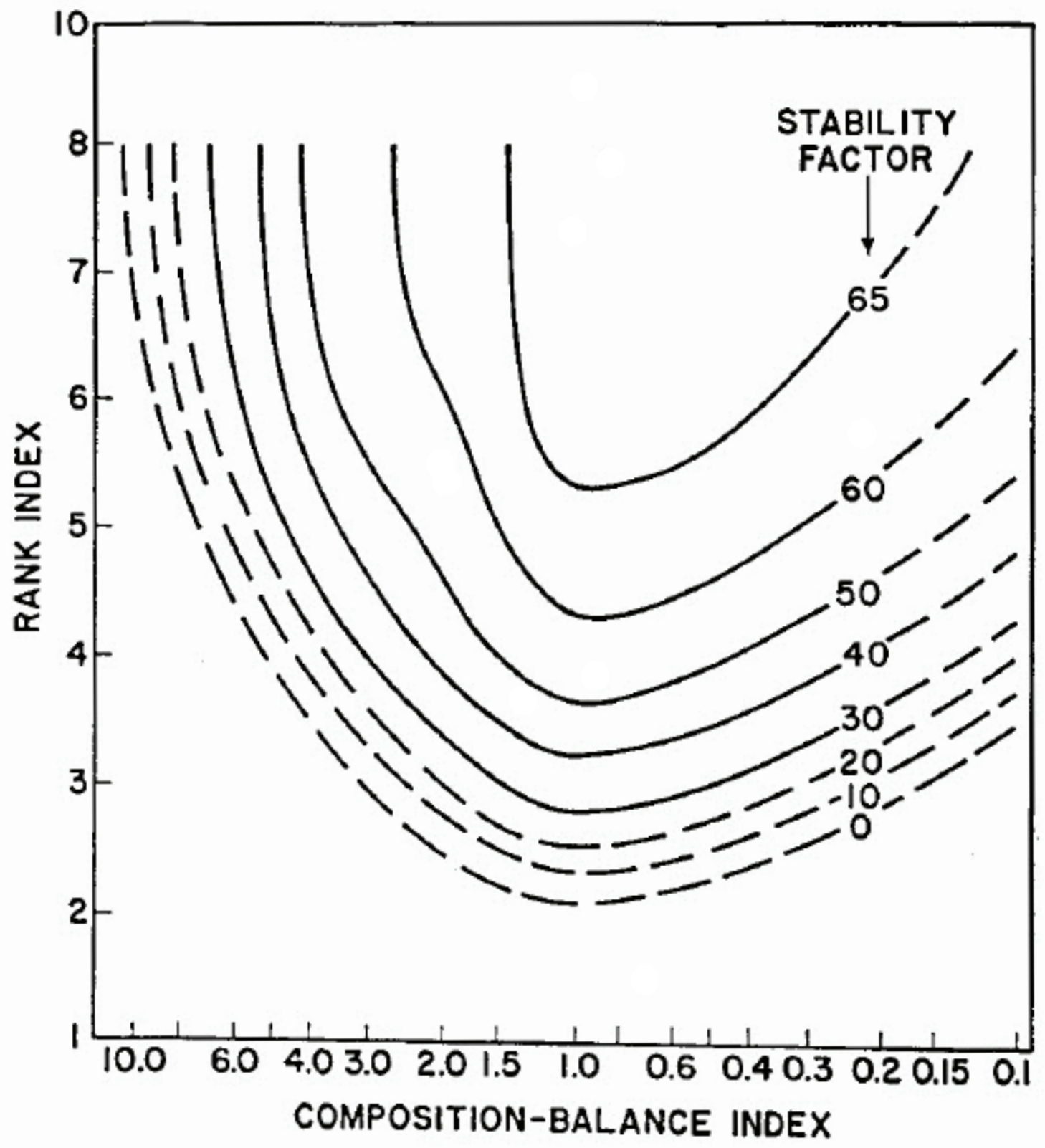

Figure 1. Chart plotting the Strength Index (SI; also called Rank Index) against Compositional Balance Index (CBI), with isostability contours for the Stability Factor (SF) (from Schapiro and Gray, 1964). Used with permission from the Energy Institute, http://www.energyinst.org. 
greater than or equal to 94 , greater than 97 , and greater than 98 are considered very good to excellent for washed high-, medium-, and low-volatile bituminous U.S. coals, respectively (tables 1 to 3). Poor to good oxidation percentages for washed bituminous U.S. coals are also shown in tables 1 to 3.

HGI is a measure of the difficulty of grinding a coal compared to several standard coal samples with known HGI values (Riley, 2007). ASTM standard D409 involves (1) grinding a 50-g coal sample in a Hardgrove machine, (2) determining how much coal will not pass through a $75-\mu \mathrm{m}$ (No. 200) sieve (+75- $\mu$ m [+No. 200] coal), (3) subtracting that amount from the original $50 \mathrm{-g}$, and (4) comparing this value to four standard calibration values. HGI values greater than 55 and less than 80 are considered very good to excellent in washed highvolatile bituminous U.S. coal, while values greater than 60 and less than 90 are best for washed medium-volatile bituminous U.S. coal, and values greater than 87 and less than 95 are best for washed low-volatile bituminous U.S. coal (tables 1 to 3). Tables 1 to 3 also show the poor to good HGI ranges for washed bituminous U.S. coals.

Ash fusion testing (ASTM standard D1857) involves creating a cone made of ash and binder, heating the cone at a specified rate in a furnace in either a reducing or oxidizing environment, and recording the temperatures at which the cone begins rounding, softens to a spherical lump, softens to a hemispherical lump, and softens to a flat layer (Riley, 2007). These four temperatures are called the initial softening temperature (IT), the softening temperature (ST), the hemispherical temperature (HT), and the fluid temperature (FT), respectively. Ash fusion temperatures are useful in determining which coals may or may not form clinkers that are easy to remove from a furnace (Riley, 2007). For washed bituminous U.S. coals, ST temperatures (in a reducing environment) greater than $2,575^{\circ} \mathrm{F}$ are considered very good to excellent to prevent damage to coke oven walls (tables 1 to 3 ). Tables 1 to 3 also show the poor to good ash fusion (in a reducing environment) ST ranges for washed bituminous U.S. coals.

The Coke Stability Factor (CSF) and Coke Hardness Factor (CHF) (both determined using ASTM standard 3402) are measures of the resistance of a coke to degradation caused by impact and abrasion during removal from coke ovens, transportation, and during its descent inside a blast furnace. In this test, 10 kilograms $(\mathrm{kg})$ of coke that passes a 75 -millimeter $(\mathrm{mm})(3-\mathrm{in}$.) sieve and is retained on a 50-mm (2-in.) sieve ( $-75 \mathrm{~mm}$ [-3 in.] $+50 \mathrm{~mm}$ [ $+2 \mathrm{in}$.] coke) is dried to less than 1 percent moisture. If it is impossible to obtain $10 \mathrm{~kg}$ of coke that meets these specifications, then one can use five $\mathrm{kg}$ of 63by $50-\mathrm{mm}$ (2.5- by 2-in.) coke plus five $\mathrm{kg}$ of 50 - by $37.5-\mathrm{mm}$ (2- by 1.5-in.) coke instead. The sample is then placed in a tumbler machine where it is rotated at 24 revolutions per minute (rpm) for 1,400 revolutions. After tumbling, the coke sample is removed from the tumbler drum and passed through a 25-mm (1-in.) sieve followed by a 6.3-mm (1/4-in) sieve. The coke remaining on each of the two sieves $(+25 \mathrm{~mm}[+1 \mathrm{in}$.] coke and $+6.3 \mathrm{~mm}[+1 / 4 \mathrm{in}$.] coke) is weighed and the CSF and $\mathrm{CHF}$ are calculated using the following two equations:

\author{
$\mathrm{CSF}=100 \mathrm{x}$ (weight of $+25-\mathrm{mm}[+1$ in. $]$ coke / pre-rotation \\ weight of coke) \\ $\mathrm{CHF}=100 \mathrm{x}$ (weight of $+6.3-\mathrm{mm}[+1 / 4$ in. $]$ coke / \\ pre-rotation weight of coke)
}

As described already in the "Petrographic Analyses" section, CSF is often predicted (pCSF) using data from petrographic analyses following the method used by U.S. Steel (Schapiro and others, 1961; Schapiro and Gray, 1964) instead of performing the test described above on an actual coke sample.

The Coke Reactivity Index (CRI) and Coke Strength after Reaction (CSR) tests (both described in ASTM standard D5341) are used to estimate the amount of degradation of coke in the blast furnace caused by reaction with carbon dioxide $\left(\mathrm{CO}_{2}\right)$ gas and abrasion between coke and other solids. In the CRI test, a sample of coke is prepared by crushing and sieving to remove any material less than $22.4 \mathrm{~mm}$ ( $7 / 8 \mathrm{in}$.) or greater than $19.0 \mathrm{~mm}$ (3/4 in.), then dried to less than one percent moisture. A 200-g portion of the sample is then heated in a furnace at $1,100{ }^{\circ} \mathrm{C}$ in a $\mathrm{CO}_{2}$ atmosphere. After two hours, the coke is removed from the furnace and weighed. The CRI value is calculated using the following equation:

$$
\begin{gathered}
\mathrm{CRI}=100 \mathrm{x} \text { (post-reaction weight of coke / pre-reaction } \\
\text { weight of coke })
\end{gathered}
$$

The coke is then placed in a tumbler and revolved 600 times in 30 minutes. After completion of tumbling, the coke is removed from the tumbler and any $-9.5-\mathrm{mm}(3 / 8 \mathrm{in}$.) material is removed by sieving. The remaining $+9.5-\mathrm{mm}(+3 / 8 \mathrm{in}$.) coke is weighed. The CSR value is calculated using the following equation:

$$
\begin{gathered}
\mathrm{CSR}=100 \times \text { (post-tumbling weight of }+9.5-\mathrm{mm}[+3 / 8 \text { in. }] \\
\text { coke } / \text { post-reaction weight of coke })
\end{gathered}
$$

For coke made from washed, high- and low-volatile bituminous U.S. coals, CSR values greater than 56 percent are considered to be very good to excellent; for coke made from washed medium-volatile bituminous U.S. coals, CSR values greater than or equal to 60 percent are considered to be very good to excellent (tables 1 to 3 ). Tables 1 to 3 also show the poor to good CSR ranges for coke made from washed bituminous U.S. coals.

As with pCSF calculations described in the Petrographic Analyses section above, several mathematical calculations using chemical, rheological, and petrographic data on coal samples have been developed to predict CSR (Valia, 1987, 1989, 1990; Grandsen and others, 1991; Diez and others, 2002; Jordan, 2006; Nag and others, 2009). Inland Steel used the following equations to predict CSR (pCSR) using chemical and rheological data (Valia, 1987, 1989, 1990; Diez and others, 2002): 
$\mathrm{pCSR}=28.91+(0.63 \times \mathrm{PR})-(9.69 \times \mathrm{AI})-(14.04 \times \mathrm{S})$

where PR is Gieseler plastic range, $\mathrm{S}$ is total percentage of sulfur (dry), and AI is the Alkali Index, which is determined by the following equation:

$$
\begin{gathered}
\mathrm{AI}=\operatorname{ash}(\text { dry }) \times\left(\mathrm{Fe}_{2} \mathrm{O}_{3} \%+\mathrm{CaO} \%+\mathrm{MgO} \%+\mathrm{K}_{2} \mathrm{O} \%+\right. \\
\left.\mathrm{Na}_{2} \mathrm{O} \%\right) /\left(\mathrm{SiO}_{2} \%+\mathrm{Al}_{2} \mathrm{O}_{3} \%\right)
\end{gathered}
$$

We used these equations to calculate pCSR for coal samples collected for this study and coal data shared with us by three coal companies, ArcelorMittal, Corky's Carbon Consultancy, and an anonymous mining company. Alkali index and pCSR values are listed in appendix 4 and discussed in the "Discussion of Results" section. These data can also be downloaded from https://doi.org/10.5066/P9KFQOKM.

\section{Coking Coal Deposits of the United States}

\section{Coking Coal Deposits of the Western United States}

Coal deposits in nine western States including Alaska, Arkansas, Colorado, Montana, New Mexico, Oklahoma, Utah, Washington, and Wyoming, were mined in the late 19th century and throughout the 20th century. Currently, Arkansas is the only western State with active coking coal mines. A map of all coal fields in the conterminous United States by East (2012) can be downloaded at https://pubs.er.usgs.gov/ publication/ofr20121205.

\section{Coking Coals in Alaska}

There are three known locations of coking coal in Alaska: (1) northwest Alaska near Cape Beaufort and the Kokolik and Kukpowruk Rivers (Warfield and others, 1966; Warfield and Boley, 1969; Alaska Division of Geological and Geophysical Surveys [ADGGS], 1990); (2) the Matanuska River valley located about 50 miles northeast of Anchorage, Alaska (Toenges and Jolley, 1949; Barnes and Ford, 1952; Hankinson, 1965; Merritt and Hawley, 1986; ADGGS, 1990); and (3) the Bering River coal field located about 200 miles east of Anchorage and 12 miles northeast of Katalla, Alaska (Brooks, 1905; Barnes, 1951; Merritt and Hawley, 1986; ADGGS, 1990) (locations 1 to 6 on figs. 2 to 4 ).

Middle to late Lower Cretaceous to Upper Cretaceous Nunashuk Formation (known as the Corwin Formation in the 1950s through 1970s) coal beds in northwestern Alaska (near Cape Beaufort and the Kokolik and Kukpowruk Rivers) have been shown to have coking qualities that may make them useable for the creation of metallurgical coke (locations 1 to 3 on figs. 2 and 3). Coking coals in the Kukpowruk River valley were first explored by the Morgan Coal Company in 1954 (ADGGS, 1990); Union Carbide and Kaiser Engineers continued investigating them from 1960 to 1963 and 1970 to 1977 , respectively (ADGGS, 1990). Warfield and others (1966) conducted laboratory tests on eight samples from two coal beds near the Kukpowruk River in 1962 and 1963 to determine their coking quality (location 1). They found that the lower and thicker (about 20-ft) of the two beds yielded a satisfactory coke when blended with coking coal from West Virginia. In 1964, Warfield and Boley (1969) collected and tested outcrop samples of three additional Nunashuk (Corwin) Formation coal beds near the Kokolik River (location 2) and six coal beds from six outcrops near Cape Beaufort (location 3). The lowermost bed near the Kokolik River, exhibited significant coking properties when blended with low-volatile bituminous coals from West Virginia, but none of the Cape Beaufort outcrop samples exhibited significant coking properties. In addition, in 1966 four cores were drilled in the 20-ft coal bed near the Kukpowruk River (location 1), and another core was drilled near Cape Beaufort (location 3). The Kukpowruk River cores confirmed the coking properties of the lowermost and thickest (20 ft) coalbed. The Cape Beaufort cored samples (from $200 \mathrm{ft}$ below the surface) also showed coking properties. In contrast to results reported by Warfield and Boley (1969), the U.S. Bureau of Mines (USBM) found that the Cape Beaufort field coals they sampled and analyzed exhibited coking qualities (Rao, 1974). Coals from the Cape Beaufort coal field, which have never been commercially mined, were also explored by the North Slope Borough from 1981 to 1986 (ADGGS, 1990). ADGGS (1990) published minimum, maximum, and average coal quality values, and average coal petrographic data for coals from Cape Beaufort and the Kukpowruk River valley. They listed these coals as high-volatile A to $\mathrm{C}$ bituminous coals with low-sulfur content (S) (less than or equal to 0.5 percent) and low to high ash yield (2.5 to 27 percent), low to medium Free-Swelling Index (0 to 6), and heating contents between 9,100 to 14,100 British thermal units per pound (Btu/lb). ADGGS (1990) estimated the coking potential of these coals to be fair to good, with the Kukpowruk River valley coals having the greatest potential.

The Paleocene to Eocene Chickaloon Formation of the Matanuska River valley includes 30 or more coal beds, some of which have good coking qualities (Toenges and Jolley, 1949; Barnes and Ford, 1952; Hankinson, 1965; Merritt and Hawley, 1986). These coals are found in two districts, from west to east they are (1) the Wishbone Hill district near Sutton, Alaska (location 4 on figs. 2 and 4); and (2) the Chickaloon district near Chickaloon, Alaska (location 5 on figs. 2 and 4) (Merritt and Hawley, 1986). The Wishbone Hill district coals have the highest potential for coking and they are high-volatile bituminous in rank with low-sulfur content ( 0.2 to 1.0 percent), low to high ash yield ( 4 to 24 percent), low Free-Swelling Index (0 to 2), and low to medium calorific value $(\mathrm{CV})(8,600$ to 13,200 British thermal units per pound [Btu/lb]) (Merritt and Hawley, 1986; ADGGS, 1990). The Chickaloon district has medium- to low-volatile bituminous 


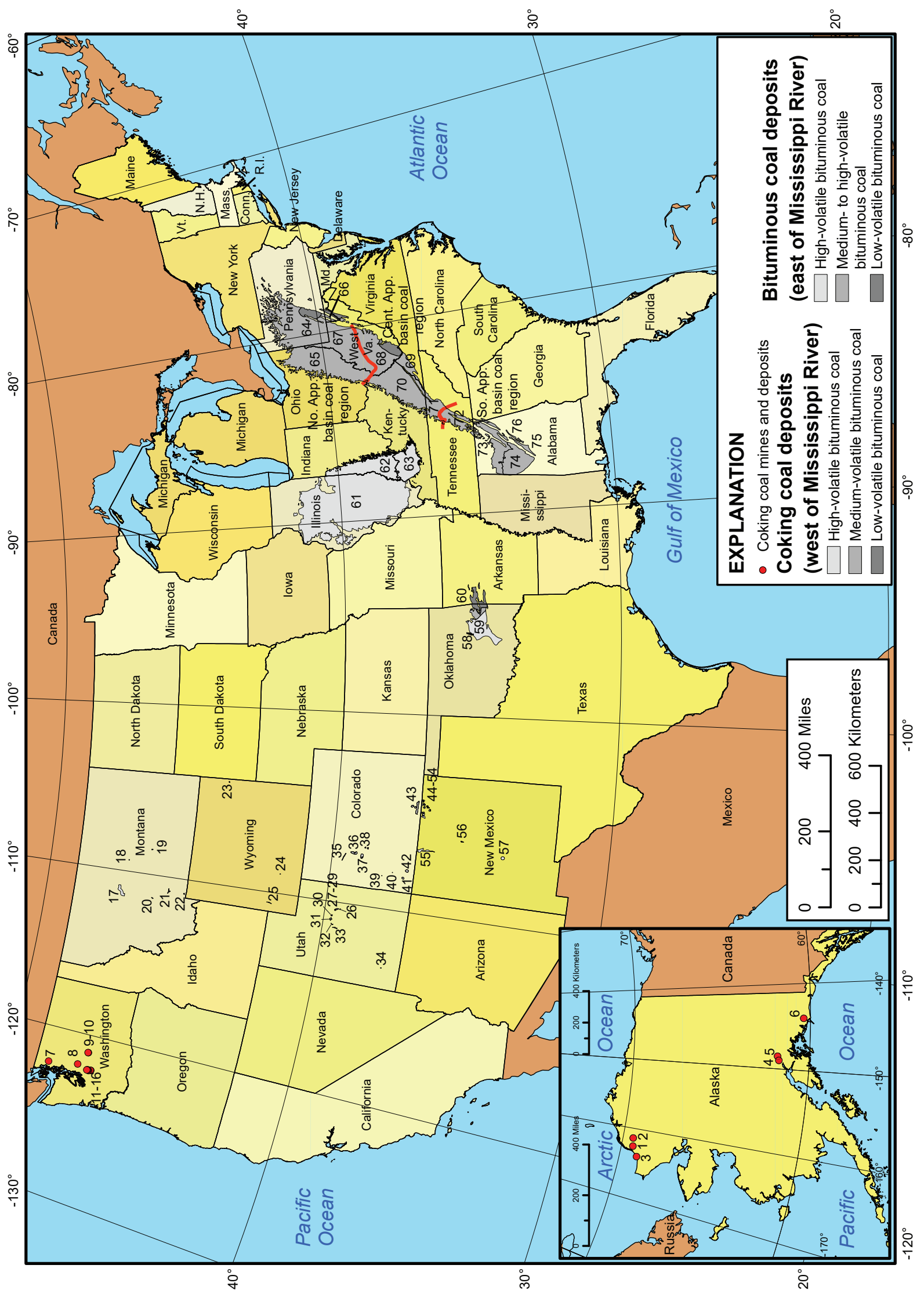

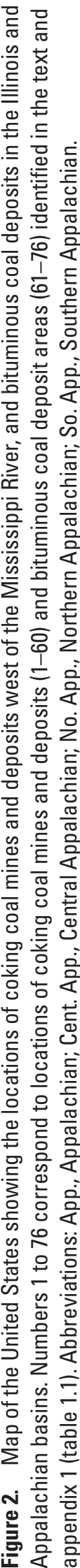




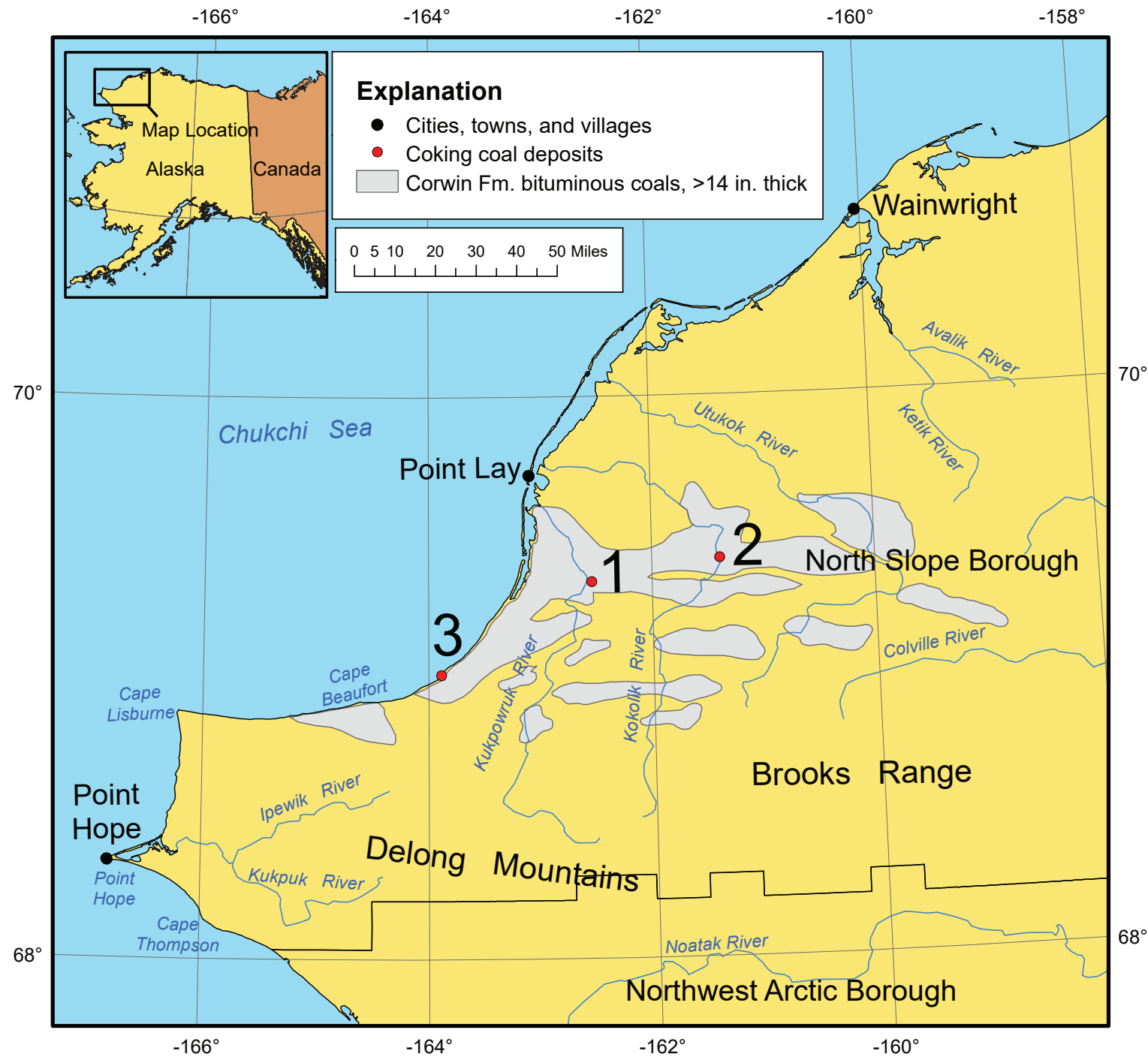

Figure 3. Map of a part of northwest Alaska showing the locations of coking coal deposits and the Corwin Formation bituminous coals near Cape Beaufort and the Kokolik and Kukpowruk Rivers. Numbers 1 to 3 correspond to coking coal deposit locations identified in the text and in appendix 1 (table 1.1). Abbreviations: Fm., Formation; in., inches.

coal with 0.2 to 0.7 percent sulfur content, 5 to 20 percent ash yield, low to high Free-Swelling Index (0 to 8), and a CV of 11,960 to 14,400 Btu/lb (Merritt and Hawley, 1986; ADGGS, 1990). Coal in the Wishbone Hill district was mined from 1914 to 1968 (ADGGS, 1990) in at least 10 mines including the Evan Jones Mine, which produced six million tons of coal between 1920 and 1968 (Ranger Alaska LLC and Alaska Earth Science, Inc., 2013). The Wishbone Hill coals are mostly found in four coal groups, which are (in descending order) (1) the Jonesville coal group in which six to seven coal beds occur, (2) the Premier coal group (eight to 12 beds), (3) the Eska coal group (three to four coal beds), and (4) the Burning Bed (or Little Eska) coal group (up to six beds) (Toenges and Jolley, 1949; Merritt and Hawley, 1986). Merritt and Hawley (1986) also recognized seven additional coal beds (five unnamed beds and the upper and lower Midway beds) not included in these four coal groups. Hankinson (1965) tested the coking characteristics of coal samples from several coal beds in the Matanuska River valley, which includes the Lower Castle Mountain beds 5, 8, 7U, and 7L from the Evan Jones Coal Mine, and the Lower Castle Mountain and Upper Castle Mountain beds from Chickaloon. Most of the beds were not suitable for direct use in coke making but could produce coke if blended with high-volatile bituminous coals; the Lower Castle Mountain bed was especially good for coke making in blends. The Matanuska River valley was the most active mining area of Alaska in the early- and middle-20th century (Toenges and Jolley, 1949), but the last active mine in this area, the Evan Jones Mine of Sutton, Alaska, closed in 1968 (ADGGS, 1990) and no commercial mining has occurred there since then. Union Pacific Resources conducted mine feasibility studies in the early 1980s (ADGGS, 1990), and recently Black 


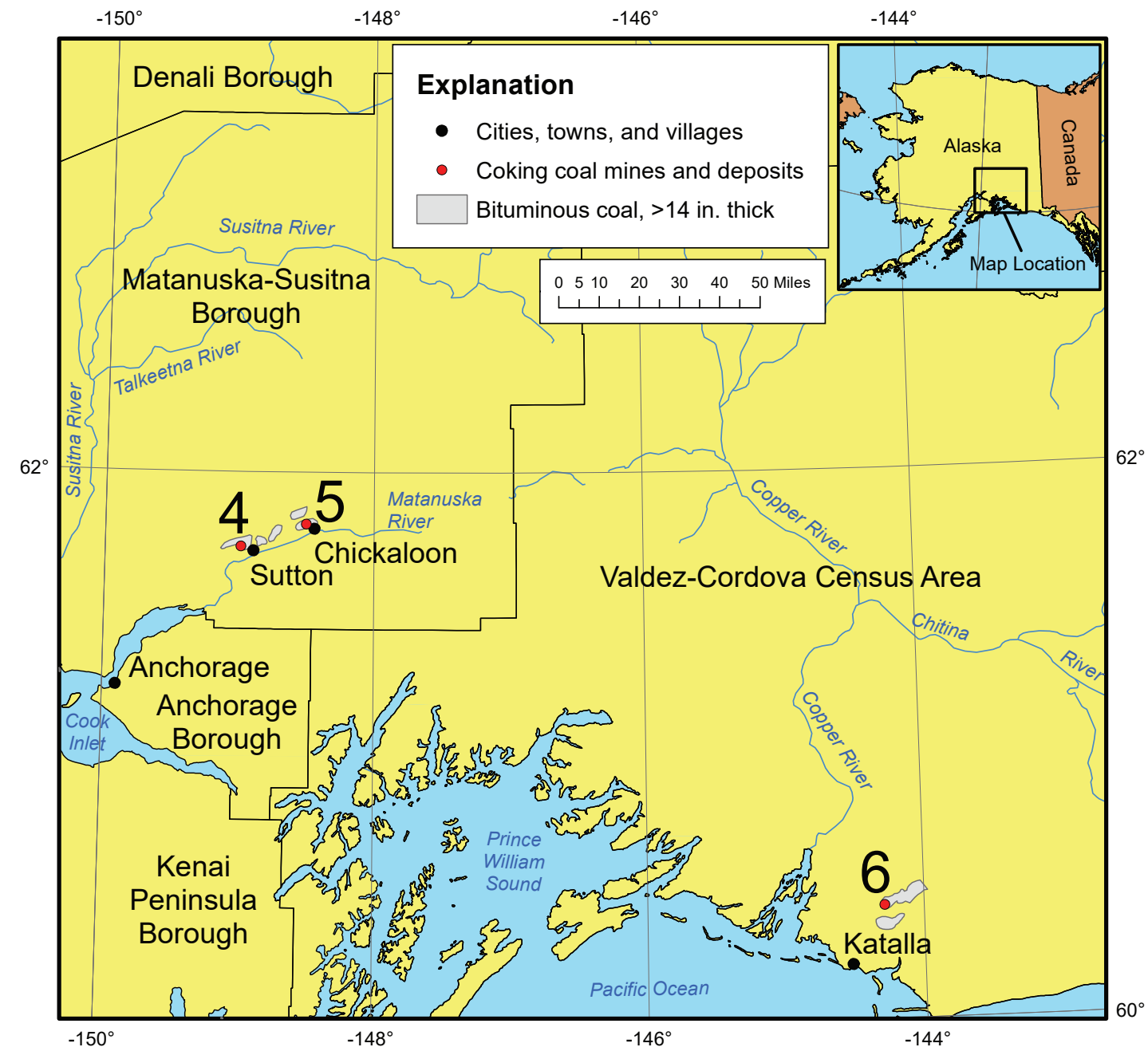

Figure 4. Map of a part of southern Alaska showing the locations of coking coal mines and deposits in the Lower Matanuska Valley and the Bering River coal field. Numbers 4 to 6 correspond to coking coal mine and deposit locations identified in the text and appendix 1 (table 1.1). Abbreviation: in., inches.

Range Minerals has shown some interest in exploring the area near the Evan Jones Coal Mine for new production of thermal coal (Black Range Minerals, 2015). ADGGS (1990) estimated the coking potential of coals from both districts to range from poor to good with the possibility that they could be used to make metallurgical coke.

The Bering River coal field, located between 10 and 30 miles northeast of Katalla, Alaska (location 6 on figs. 2 and 4), includes up to 20 coal beds ranging from 5- to 10 -ft thick, in the Oligocene (?) Kulthieth Formation (Kushtaka Formation in the 1950s) that may be of good coking quality (Barnes, 1951; ADGGS, 1990). The coal beds are composed of medium- to low-volatile bituminous coal with low-sulfur contents ( 0.1 to 1.0 percent), low to high ash yields ( 2 to 30 percent), and low to high CV $(11,000$ to $15,000 \mathrm{Btu} / \mathrm{lb})$ (Merritt and Hawley, 1986). Earlier investigators pointed out that the presence of large amounts of water and methane and the highly friable nature of the coals in this area might make them difficult to mine and ship (Martin, 1908; Storrs, 1910; Williams, 1914; Fisher and Calvert, 1914; G.W. Evans in 1920 [as referenced by Barnes, 1951]). The Bering Development Corporation (the Chugach Alaska Corporation in association with the Korea-Alaska Development Corporation) conducted exploratory drilling in the Bering River coal field in the mid-1980s (Merritt and Hawley, 1986; ADGGS, 1990); however, these coals have not been commercially mined. ADGGS (1990) published average, minimum, and maximum coal quality values (including rank, heating content, proximate analysis, ultimate analysis, major-oxide and trace-element content of ash, and FSI) for coals from the Bering River coalfield. They estimated the coking potential of the Bering River coals to be questionable if used alone, but they suggested that the coals might make good metallurgical coke, if blended with other high-volatile bituminous coals. 


\section{Coking Coals in Washington State}

There are four coal fields in Washington State that contain coal suitable for coking, including the (1) Cokedale coal field, (2) Snoqualmie coal field, (3) Roslyn-Cle Elum coal field, and (4) Wilkeson-Carbonado coal field (Berryhill and Averitt, 1951; Valentine and Huntting, 1960; Averitt, 1966; locations 7 to 16 on figs. 2 and 5). Coking coal was produced in Washington State from 1884 to 1937. Production restarted in 1944 but was short-lived. No coking coal has been produced since 1944 (Valentine and Huntting, 1960).

The Cokedale coal field in Skagit County, located about 20 miles southeast of Bellingham, Washington, contains low-volatile bituminous Tertiary coal in the Klondyke beds (Valentine and Huntting, 1960) (location 7 on figs. 2 and 5). Between 1892 and 1905 coal from the Cokedale Mine was used by the Sedro Coal Company to make coke but the mine was closed in 1921 (Valentine and Huntting, 1960). Two published analyses show the coal had low sulfur content ( 0.39 to 0.65 percent) and medium ash yield (11.91 percent) (Jenkins, 1924).

In 1908, Western Coke and Collieries Company briefly produced coking coal from the Niblock Mine in the Snoqualmie coal field, located about 30 miles east of Seattle, Washington (Valentine and Huntting, 1960; Walsh, 1983; location 8 on figs. 2 and 5). Seven beds (Nos. 1, 2, 3, 4, 5, 7, and 8) were mined in the Niblock Mine (Walsh, 1983).

High-volatile A bituminous coal of the Eocene Rosyln formation in the Rosyln-Cle Elum coal field in Kittitas County, located about 70 miles east of Tacoma, Washington, was coked experimentally, but has never been produced commercially (Berryhill and Averitt, 1951; Valentine and Huntting, 1960; Averitt, 1966) (locations 9 and 10 on figs. 2 and 5). A small quantity of fair quality coke was made from coal in the Old No. 3 mine (Valentine and Huntting, 1960; location 9). The rank, $\mathrm{CV}$, and agglutinating values of coal from the

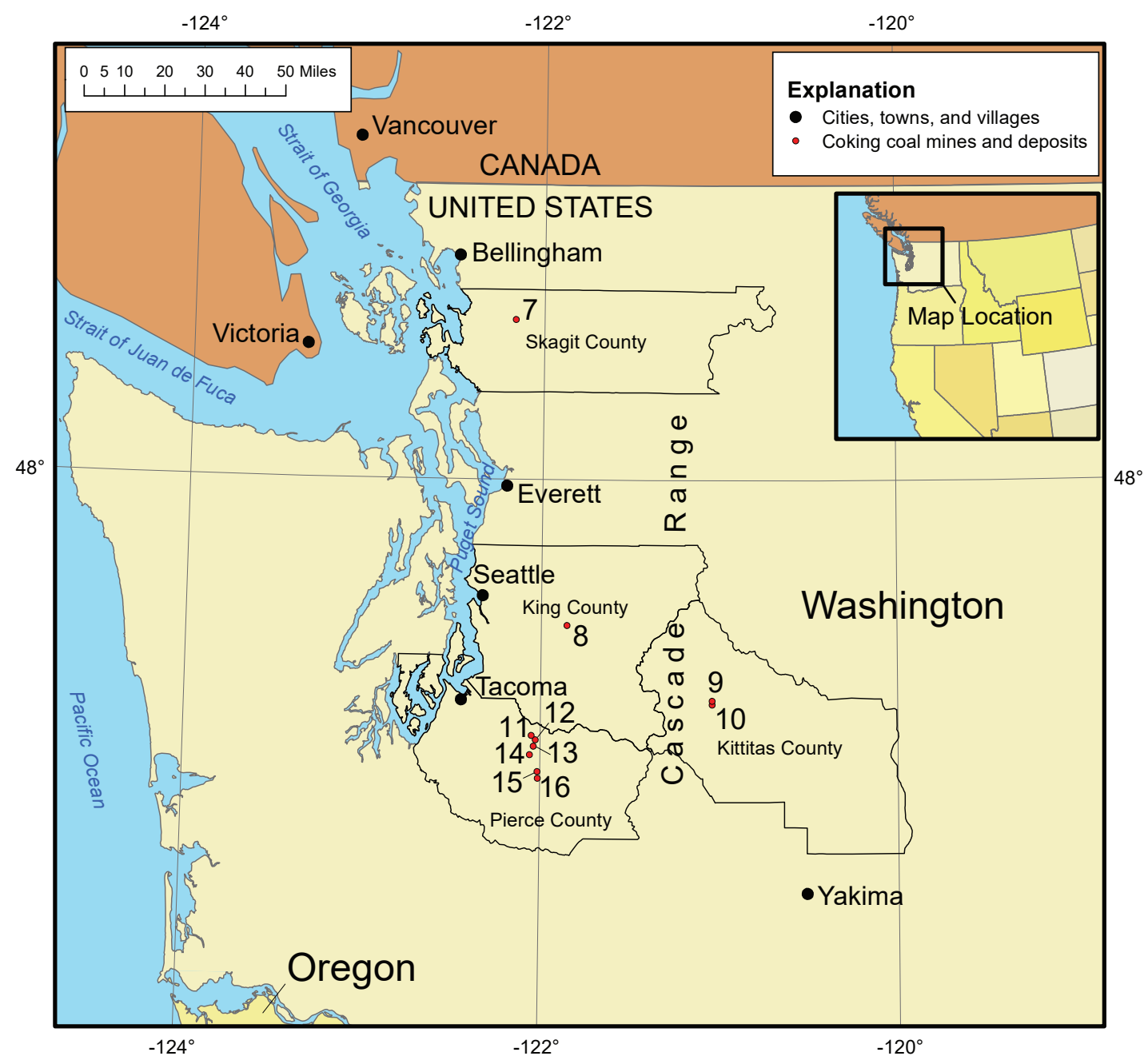

Figure 5. Map showing the locations of coking coal mines and deposits in the State of Washington. Numbers 7 to 16 correspond to coking coal mines and deposits identified in the text and appendix 1 (table 1.1). 
Roslyn bed increase with a concurrent decrease in ash yield from southeast to northwest, perhaps due to changes caused by a nearby intrusive body (Averitt, 1966). Coke made from the Rosyln bed is high in phosphorus (average of 0.66 percent), fingery (forming elongate "fingers" of coke instead of equidimensional "blocky" chunks) and tends to be weak in shatter and tumbler tests. It is considered satisfactory for use in blends or for domestic use (cooking and heating homes using stoves), but it is unsatisfactory for making metallurgical coke on its own. The Roslyn coal bed is the only bed in this coal field known to have coking properties (Averitt, 1966).

The most important coking coals in Washington State were mined from the Wilkeson-Carbonado-Fairfax coal field in Pierce County, located about 20 to 30 miles southeast of Tacoma, Washington (locations 11 to 16 on figs. 2 and 5). Numerous coal beds in the Eocene Carbonado Formation and Burnett formation of the Puget Group were mined and coked between 1880 and 1937 in the towns of (North to South) Burnett (location 11), Morristown (also known as Pittsburg and Spiketon) (location 12), Wilkeson (location 13), Carbonado (location 14), Fairfax (location 15), and Montezuma (also known as Marcy) (location 16), among others (Berryhill and Averitt, 1951; Valentine and Huntting, 1960; Beikman and others, 1961; Averitt, 1966; Daniels, 1979; Kombol, 2007). The coals in the Wilkeson-Carbonado-Fairfax coal field are low-, medium-, and high-volatile bituminous (VM ranges from 20 to 33 percent) with moderate ash yields (12 to 15 percent), low sulfur contents ( 0.6 to 0.8 percent), and relatively high phosphorus contents ( 0.05 to 1 percent) (Berryhill and Averitt, 1951; Averitt, 1966). Because these coals are high in phosphorus they are better for blends than for solitary use in coke making. No coal has been produced in Pierce County since 1975 (Schasse and others, 1984).

\section{Coking Coals in Montana}

There are three coal fields in Montana that contain coking coals: (1) Great Falls, (2) Livingston-Trail Creek, and (3) Electric coal fields (Fisher, 1909; Calvert, 1912a, 1912b; Lord and others, 1913; Dobbin and others, 1932; Silverman and Harris, 1967; Combo and others, 1949; Berryhill and Averitt, 1951; Averitt, 1966; Jay Gunderson, Montana Bureau of Mines and Geology, written commun., 2014) (locations 17, 21 , and 22 , respectively, on figs. 2 and 6). In addition, three other coal fields are reported to contain coal that has coking properties, but the coal has not been used for coke manufacturing. These coal fields include the Lewistown coal field (Calvert, 1909; Lord and others, 1913), the Bull Mountain coal field (Lord and others, 1913), and the Lombard Field (Combo and others, 1949) (locations 18, 19, and 20, respectively, on figs. 2 and 6).

The Great Falls coal field in Cascade County (location 17 on figs. 2 and 6) contains high-volatile $\mathrm{B}$ and $\mathrm{C}$ bituminous coal near the top of the Late Jurassic Morrison Formation (Fisher, 1909; Dobbin and others, 1932; Berryhill and Averitt,
1951; Averitt, 1966; Silverman and Harris, 1967). The bed is 2.5 - to 14 -ft thick, separated by partings into two to three benches that are 1 to $7 \mathrm{ft}$ each (Dobbin and others, 1932; Averitt, 1966; Silverman and Harris, 1967). This coal was used in the Anaconda coke ovens in Belt, Montana, from the 1880 s through the early 1900 s, but the ovens were abandoned because of the difficulty and expense of separating the coking coals from non-coking coals (Fisher, 1909; Dobbin and others, 1932; Averitt, 1966).

High-volatile A, B, and C bituminous coking coals in the Livingston-Trail Creek coal field in Gallatin and Park Counties (location 21 on figs. 2 and 6) are found in the structurally complex Cokedale coal bed in the Late Cretaceous Eagle Sandstone of the Montana Group (Calvert, 1912b; Dobbin and others, 1932; Combo and others, 1949; Berryhill and Averitt, 1951; Averitt, 1966). The coal bed ranges in thickness from a few inches to over $10 \mathrm{ft}$, with an average thickness of 3 to $4 \mathrm{ft}$. The coal and associated strata were highly deformed by folding and faulting, with the best coking coals found on the flanks of anticlines and the poorest coking coals found in the troughs of synclines and the tops of plunging ends of anticlines. Mining operations took place in this field from the 1880s through 1896, and then again in the early 1900 s, but no coking coal has been produced since then (Averitt, 1966).

The Electric coal field of Park County (location 22 on figs. 2 and 6) includes high-volatile $\mathrm{C}$ bituminous, mediumvolatile bituminous, and semi-anthracite coal in three coal beds, the No. 1, No. 2, and No. 3 coal beds, in the Late Cretaceous Eagle Sandstone of the Montana Group (Calvert, 1912a; Dobbin and others, 1932; Combo and others, 1949; Berryhill and Averitt, 1951; Averitt, 1966). The No. 1 bed, $300 \mathrm{ft}$ above the basal Virgelle Sandstone Member of the Eagle Sandstone, was mined extensively between 1894 and 1912. No mining has occurred in the No. 1 coal bed since 1912. Its thickness ( 1.5 to $5 \mathrm{ft}$, average of $3 \mathrm{ft}$ ) and purity are highly variable, containing clay and sandstone partings, and sometimes occurring as local lenses within a thicker carbonaceous sequence. The No. 2 and No. 3 coal beds, 100 and $50 \mathrm{ft}$ above the Virgelle Sandstone Member, respectively, are also coking coals over parts of the field, but were not mined because they were too thin, deep, discontinuous, impure, and (or) did not coke well. High-quality coke from the Electric coal field was shipped to copper smelters in Anaconda and Butte, Montana, from 1894 to 1912, but it was difficult to meet the smelting requirements for less than 18 percent ash in metallurgical coke, and mining was halted.

Bituminous coal from the Mace Mine in Maiden, Montana (location 18 on figs. 2 and 6), in the Lewistown coal field of Fergus County, is reported to coke well after removal of sulfur, but this coal has never been used for making coke (Calvert, 1909; Lord and others, 1913). Coals that will produce coke were also found in three mines in the Tertiary Fort Union Formation in the Bull Mountain Field near Roundup, Montana, in Musselshell County (location 19 on figs. 2 and 6), but they were never used for coke making (Lord and 


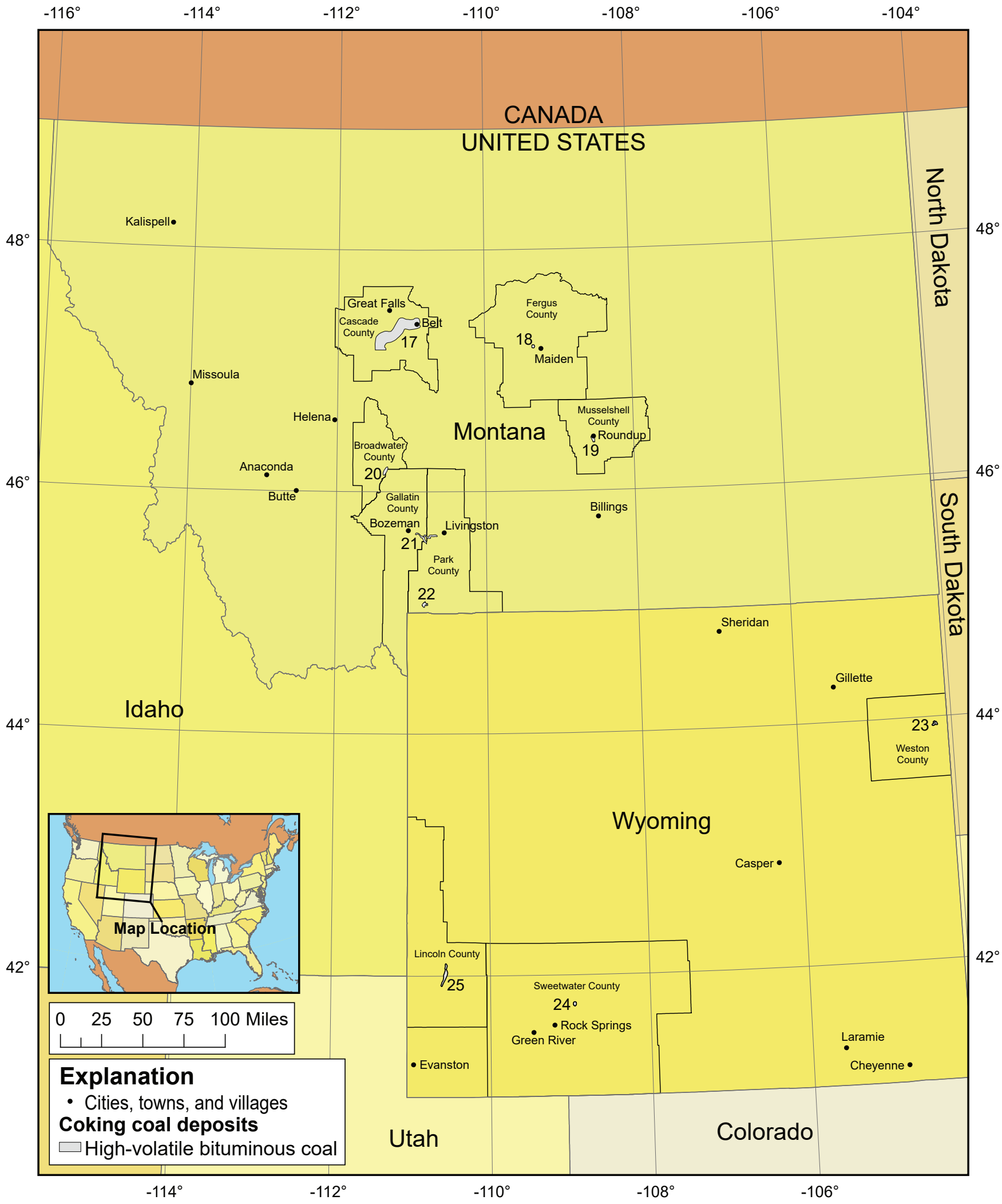

Figure 6. Map showing the locations of coking coal deposits in the States of Montana and Wyoming. Numbers 17 to 25 correspond to coking coal deposit areas identified in the text and appendix 1 (table 1.1). 
others, 1913). The Lombard Field (location 20 on figs. 2 and 6) of Broadwater and Gallatin Counties also contains coal that exhibits coking properties, but it has never been used for coking (Combo and others, 1949).

\section{Coking Coals in Wyoming}

There are three known locations of coking coal in Wyoming: (1) the Cambria coal field in Weston County, (2) the Rock Springs coal field in Sweetwater County, and (3) the Kemmerer-Willow Creek coal field of Lincoln County (Darton, 1905; Toenges and others, 1945; Berryhill and others, 1950; Berryhill and Averitt, 1951; Averitt, 1966; Rich and others, 1988) (locations 23 to 25 on figs. 2 and 6).

A single discontinuous 4- to 10-ft-thick bed of highvolatile $\mathrm{C}$ bituminous coking coal is present in the Cambria coal field of the Black Hills region about 6 miles north of Newcastle, Wyoming (location 23 on figs. 2 and 6) in the Early Cretaceous Lakota Formation (Darton, 1905; Berryhill and others, 1950; Berryhill and Averitt, 1951; Averitt, 1966; Rich and others, 1988; Johnston and others, 2014). Mining operations occurred in this field from 1889 through 1928 and the $\mathrm{C}$ coal bed was used for coke between 1891 and 1906, but no coking coal has been produced since then (Berryhill and others, 1950; Berryhill and Averitt, 1951; Averitt, 1966; Rich and others, 1988). There were 74 beehive ovens producing up to 74 tons of coke per day in the early 20th century until mining operations ceased in 1928 (Johnston and others, 2014).

In the Rock Springs coal field of the Green River region (location 24 on figs. 2 and 6), coal from the Superior A Mine that is less than a mile southeast of Superior, Wyoming, was used to make a poor-quality coke that was deemed unsuitable for metallurgical purposes (Berryhill and others, 1950; Berryhill and Averitt, 1951; Averitt, 1966). It was a highvolatile $\mathrm{C}$ bituminous coal that came from the lowermost part of the Rock Springs No. 7 coal bed in the Late Cretaceous Mesaverde Group. A plant was built in this area for manufacturing coke to be used in the creation of elemental phosphorus in 1963 (Averitt, 1966).

In the 1940s, The U.S. Bureau of Mines and the U.S. Geological Survey cooperated in a study of the coking properties of several Late Cretaceous Frontier Formation coal beds (including the Willow Creek No. 5, or Middle Main bed) in the Kemmerer-Willow Creek coal field of the Hams Fork region (location 25 on figs. 2 and 6 ) in a narrow synclinal belt about 12 miles north of Kemmerer, Wyoming (Toenges and others, 1945; Berryhill and others, 1950; Berryhill and Averitt, 1951; Averitt, 1966; Jones and others, 2011). These coals were high-volatile A bituminous coal and were considered unsuitable for use in blast furnaces unless cleaned and blended with coals of superior coking ability like the Sunnyside coal from Utah (Berryhill and others, 1950; Berryhill and Averitt, 1951; Averitt, 1966).

\section{Coking Coals in Utah}

Coking coal occurs in four coal fields in Utah: (1) the Sunnyside-Castlegate (Book Cliffs) coal field of eastern Carbon County, (2) the Wasatch Plateau coal field of western Carbon County and northwest Emery County, (3) the Mount Pleasant coal field of Sanpete County, and (4) the Kolob (Kanab) coal field of Iron County (locations 26 to 34 on figs. 2 and 7) (Averitt, 1966; Jahanbani, 1996).

For many years the Sunnyside-Castle Gate field (also called the Book Cliffs field) was the most important supplier of coking coal in the western United States (locations 26 to 31 on figs. 2 and 7) (Averitt, 1966). Coals from this field were coked locally and used in steel plants in Utah and southern California (Averitt, 1966; Jahanbani, 1996). Up to eleven coal beds are found in the Late Cretaceous Blackhawk Formation (Mesaverde Group), the most important being the Lower Sunnyside bed (Gloyn and others, 2003; Averitt, 1966). Multiple mines in the Sunnyside-Castle Gate field, including (from southeast to northwest) the Geneva (Horse Canyon) (location 26), Columbia (location 27), Sunnyside (location 28), West Ridge (location 29), Kenilworth (Aberdeen) (location 30), and Castle Gate (location 31) mines produced coking coal from 1888 onwards (Jahanbani, 1996; UtahRails.net, 2015), but there has been no coal mined for coke-making in Utah since 2001 (Utah Geological Survey, Utah Energy Office, 2003). The Sunnyside mine produced the best quality coking coal in the field which was highvolatile $\mathrm{A}$ and $\mathrm{B}$ bituminous coal with 0.9 to 1.3 percent sulfur, 38.5 percent VM, and 12,799 Btu/lb (Averitt, 1966). Sunnyside's major client, Kaiser Steel, closed its southern California Fontana plant in 1982. Despite this setback, the mine continued operating until 1994 when its contract with Geneva Steel of Orem, Utah, was not renewed (Jahanbani, 1994, 1995). After the closing of Sunnyside, Geneva Steel purchased coke from Japan and China and coking coal from several companies in Colorado, Pennsylvania, West Virginia, and Virginia (Jahanbani, 1995, 1996, 1997, 1998, 1999, 2000). In 2000, the West Ridge mine (location 29 on figs. 2 and 7) and the White Oak mines (location 32) in the Wasatch Plateau coal field in western Carbon County also supplied coking coal to Geneva Steel, but in 2001 Geneva Steel closed its doors, which effectively ended the production of coking coal in Utah except for a very small amount used by Pacific States Steel (in Utah County), some universities, specialty metal shops, foundries, ceramic, and metalwork facilities (Utah Geological Survey, Utah Energy Office, 2003; Utah Energy Office, 2003, 2004).

Coking coal was discovered in the Wasatch coal field near Scofield (Pleasant Valley), Utah (on fig. 7) between 1874 to 1875 and was locally coked and transported by wagon to Springville, Utah, but the mine was not profitable and closed after only a few years (Jahanbani, 1996). As already 
mentioned above, the White Oak mines (location 32) in the Wasatch Plateau coal field in western Carbon County supplied coking coal to Geneva Steel in 2000 before its closure in 2001.

The Mount Pleasant coal field (location 33 on figs. 2 and 7) near the town of Mount Pleasant in Sanpete County, Utah, has six unnamed coal beds in the Upper Cretaceous Blackhawk Formation (Berryhill and Averitt, 1951). These high-volatile A and B bituminous coals were cored in 1943 and a sample from the thickest bed contained 3.2 percent moisture, 42.9 percent VM, 8.6 percent ash, 0.6 percent sulfur, and $12,890 \mathrm{Btu} / \mathrm{lb}$ (on an as-received basis [ar]) (Berryhill and Averitt, 1951). Coke made from samples of these coals is softer and weaker than coke made from Sunnyside coal, and is therefore considered unsuitable for metallurgical use (Berryhill and Averitt, 1951).

Late Cretaceous subbituminous A and high-volatile C bituminous coking coal from the Upper Culver coal zone of the Tropic shale (Averitt, 1966, and Berryhill and Averitt, 1951, call it the Benton Shale) in the Kolob coal field (called the Kanab coal field by Berryhill and Averitt, 1951) (location 34 on figs. 2 and 7) of Iron County, Utah, is high in sulfur, friable, and unsuitable for steel making, and was once used for lead smelting with unsatisfactory results (Averitt, 1966; Jahanbani, 1996). A sample from the Jones Mine near Cedar City had 36.3 percent VM, 9.6 percent ash, 5.8 percent sulfur, and 10,870 Btu/lb (Berryhill and Averitt, 1951).

\section{Coking Coals in Colorado}

Coking coal occurs in three coal regions of Colorado: (1) the Uinta coal region in Delta, Garfield, Gunnison, and Pitkin Counties; (2) the San Juan River coal region in Dolores, La Plata, Montezuma, Montrose, and San Miguel Counties; and (3) the Raton (Mesa) coal region in Las Animas County (locations 32 to 43 on figs. 2 and 7) (Averitt, 1966; Goolsby and others, 1979; Tremain and others, 1996; Schultz and others, 2000; Carroll, 2006, 2011).

Within the Uinta coal region there are four coal fields with coking coal: (1) the Grand Hogback coal field of Garfield County (location 35 on figs. 2 and 7), (2) the Carbondale coal field of Gunnison and Pitkin Counties (location 36), (3) the Somerset coal field of Delta and Gunnison Counties (location 37), and (4) the Crested Butte coal field of Gunnison County (location 38) (Averitt, 1966; Goolsby and others, 1979; Tremain and others, 1996).

The Grand Hogback coal field (location 35 on figs. 2 and 7) has marginal- to premium-grade coking coal of highvolatile A and B bituminous rank in township 5 North in Garfield County (Goolsby and others, 1979). Only 375 tons of coal were produced in the Grand Hogback coal field in 1995 (Tremain and others, 1996), and no production has been reported since (Carroll, 2006, 2011; Chris Carroll, Colorado Geological Survey, written commun., 2014).
The Carbondale coal field (location 36 on figs. 2 and 7) includes up to eight coal beds in the lower Bowie Shale Member and the upper Paonia Shale Member of the Upper Cretaceous Mesaverde Formation (Averitt, 1966). Goolsby and others (1979), Tremain and others (1996), and Carroll (2006) call these rocks the Williams Fork Formation of the Mesaverde Group. These coals range from high-volatile B bituminous to anthracite (Averitt, 1966; Goolsby and others, 1979) with moderate ash yield and low sulfur content (Averitt, 1966). The coals of Pitkin County have the strongest coking properties (Averitt, 1966). The Carbondale coal field was an important source of coking coal in the early 20th century with active mines near the towns of Placita and Coal Basin (Averitt, 1966). Production declined after World War I to less than 50,000 tons annually, but in the 1950s the Carbondale coal field began supplying coking coal to the Geneva Steel plant of Orem, Utah, and production increased to greater than 600,000 tons (Averitt, 1966). Mid-Continent Resources, Inc. of Carbondale, Colorado, began selling hard coking coal to the Geneva Steel plant in the early 1990s (Jahanbani, 1991). At that time, Mid-Continent Resources, Inc. had the only medium-volatile bituminous, hard coking coal available in the western United States. After a brief mine shutdown in August 1990 due to a fire, mining and shipment of coal to Utah was resumed (Jahanbani, 1991). By 1995, all coal mining ceased in the Carbondale coal field (Tremain and others, 1996; Carroll, 2006, 2011; Chris Carroll, Colorado Geological Survey, written commun., 2014).

The Somerset coal field (location 37 on figs. 2 and 7) includes two important coal beds, the lower Snowshoe and upper Bear coal beds, both in the Bowie Shale Member of the Mesaverde Formation (Averitt, 1966). Coals from the lower bench of the Snowshoe bed and the Bear bed (the A and C coal beds of the Mesaverde Group of Goolsby and others [1979] and Schultz and others [2000]) coke better than the coal from Sunnyside coal field of Utah, while coal from the upper bench of the Snowshoe bed (B bed) is slightly inferior to Sunnyside field coals (Averitt, 1966). All three Somerset field coals contain less than one percent sulfur and less than 11 percent ash, making them suitable for metallurgical quality coke (Averitt, 1966). Coal rank ranges from high-volatile C bituminous to anthracite (Averitt, 1966; Goolsby and others, 1979; Tremain and others, 1996; Carroll, 2006). Goolsby and others (1979) describe these coals as ranging from premium (medium-volatile bituminous) to marginal (high-volatile bituminous) in coking grade. In the 1990s, Geneva Steel of Orem, Utah, purchased coking coal from the Bear Coal Company of Somerset, Colorado, and Oxbow Carbon and Mineral of Littleton, Colorado; both companies mined from the same bed in the Somerset coal field (Jahanbani, 1991, 1996). In 2000, only three mines were producing coal in the Somerset coal field: (1) the Sanborn Creek mine (in the B bed), (2) the West Elk Mine (in the B bed), and (3) the Bowie No. 2 Mine (in the 
$-114^{\circ}$

$-112^{\circ}$

$-110^{\circ}$

$-108^{\circ}$

$-106^{\circ}$

$-104^{\circ}$

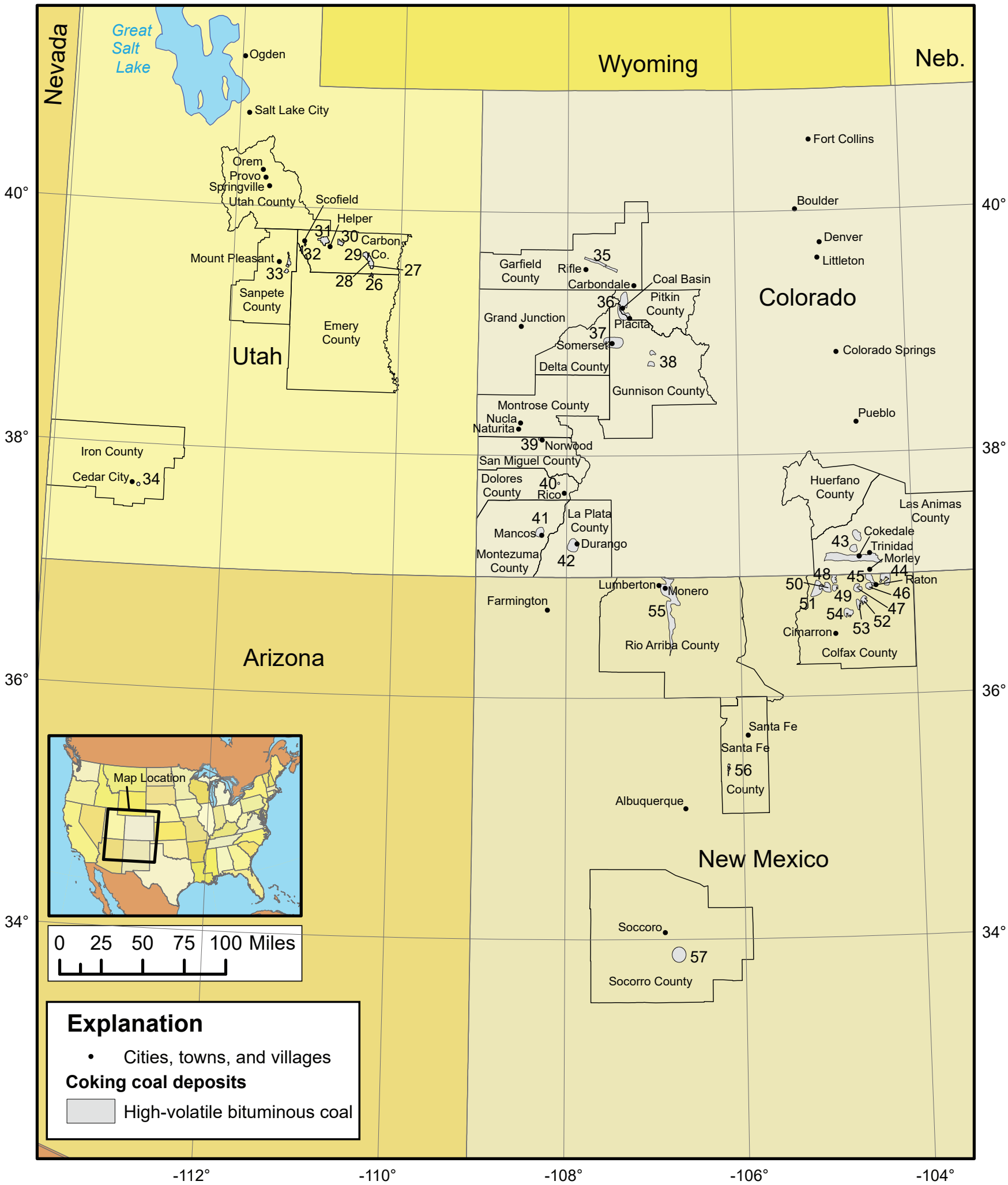

Figure 7. Map showing the locations of coking coal deposits in the States of Utah, Colorado, and New Mexico. Numbers 26 to 57 correspond to coking coal deposits identified in the text and appendix 1 (table 1.1). 
D bed) (Schultz and others, 2000). B coal bed samples had the following characteristics: 4.4 to 8.2 percent moisture, 33.4 to 36.4 percent VM, 8 to 12 percent ash, 0.4 to 0.6 percent sulfur, 11,500 to $13,000 \mathrm{Btu} / \mathrm{lb}$, and 0 to $0.5 \mathrm{FSI}$ (Schultz and others, 2000). D bed samples had 5.1 to 8.5 percent moisture, 34.4 to 38.2 percent $\mathrm{VM}, 6$ to 12 percent ash, 0.5 to 0.7 percent sulfur, 11,500 to $13,000 \mathrm{Btu} / \mathrm{lb}$, and 0 to $4.0 \mathrm{FSI}$. In 2006, the Bowie No. 2/No. 3 Mines and the West Elk Mine were still in operation producing 4.09 million tons and 5.58 million tons, respectively. A third, the Elk Creek Mine, was also in operation (producing 6.5 million tons) (Carroll, 2006). In 2011, the Bowie No. 3, West Elk, and Elk Creek Mines were still producing (Carroll, 2011), but by 2014 no mines were operating in the Somerset coal field (Chris Carroll, Colorado Geological Survey, written commun., 2014). However, the Arch Coal website indicated in April of 2019 that the Elk Creek Mine was once again active, and that 4.9 million tons were produced in 2017 (Arch Coal, 2019).

The Crested Butte coal field (location 38 on figs. 2 and 7) has up to five coal beds in the Paonia Shale Member of the Mesaverde Formation ranging from subbituminous A to anthracite (Averitt, 1966; Tremain and others, 1996; Carroll, 2006). About 85 percent of the coal is bituminous and exhibits coking properties (Averitt, 1966). No mines were operating in the Crested Butte coal field in 1995 and none have been reported since (Tremain and others, 1996; Carroll, 2006, 2011; Chris Carroll, Colorado Geological Survey, written commun., 2014).

The San Juan River coal region in Dolores, La Plata, Montezuma, Montrose, and San Miguel Counties has coking coal in four areas: (1) near the town of Norwood in Montrose and San Miguel Counties (location 39 on figs. 2 and 7), (2) near the town of Rico in Dolores County (location 40), (3) west of the town of Mancos in Montezuma County (location 41), and (4) in the Durango coal field in La Plata County (location 42) (Averitt, 1966; Goolsby and others, 1979; Tremain and others, 1996; Carroll, 2006).

The Norwood and Rico area coals (locations 39 and 40, respectively, on figs. 2 and 7) in the Lower Cretaceous Dakota Group were used for low-grade coke manufacture in the 1890s but were abandoned when the superior Durango coal field coal became available (Averitt, 1966). Goolsby and others (1979) report high-volatile A and B coals from the NuclaNaturita coal field (30 miles west of Norwood) have 13,690 to $14,310 \mathrm{Btu} / \mathrm{lb}, 0.7$ to 0.8 percent sulfur, 8.8 to 23 percent ash, and 1.0 FSI (Goolsby and others, 1979).

Carroll $(2006,2011)$ shows an area just west of the town of Mancos (location 41 on figs. 2 and 7) in Montezuma County with coking coal, but no further information is given about this area, and it is not mentioned in any other publications (Carroll, 2006, 2011). We assume that it has coal with characteristics similar to the Durango coals located 20 miles to the east.

Durango coal field coals (location 42 on figs. 2 and 7) are present in the Upper Cretaceous Menefee and Fruitland Formations, and the Lower Cretaceous Dakota Formation.
There are up to four coal beds present in the Menefee Formation with coking properties, two of which have been mined (Averitt, 1966). These coals were used to make coke for smelting ovens in the past and, with cleaning and processing, may be used for metallurgical coke manufacture (Averitt, 1966). These coals have high ash yield, but locally are of good coking quality (Tremain and others, 1996). Sample analyses from coals in the Durango area had average values of 12.7 percent ash yield, 0.8 percent sulfur content, and $12,758 \mathrm{Btu} / \mathrm{lb}$ (Carroll, 2006). These coals ranged in rank from high-volatile A bituminous to high-volatile $\mathrm{C}$ bituminous. No mines in the San Juan River coal region were in operation in 2006 (Carroll, 2006), but the King II Mine opened in 2007 and produced approximately 550,000 tons in 2017, mainly for the cement industry (Brian Shaffer, U.S. Geological Survey, written commun., 2019).

The Raton (Mesa) coal region (location 43 on figs. 2 and 7) of Huerfano and Las Animas Counties was an important supplier of coking coal to the steel industry for decades in the 20th century (Averitt, 1966). Multiple coking coal beds are present in the Upper Cretaceous Vermejo Formation and the overlying Upper Cretaceous Raton Formation (Tremain and others, 1996). The Trinidad coal field (location 43) in Las Animas County contains coking coal, while the Walsenberg coal field in Huerfano County (not shown on map) generally contains thermal non-coking coal (Tremain and others, 1996).

The Morley Mine, located near the town of Morley, was opened in 1906 by Colorado Fuel and Iron (CF\&I) (Pillmore and others, 1999). It supplied coking coal to steel mills in Pueblo, Colorado, during the first half of the 20th century, until closing in 1956. At its peak in the late 1920s, the Morley mine produced 500,000 tons per year. Over the life of the mine, 11 million short tons of coking coal were produced from the Morley mine.

In the town of Cokedale, Colorado, the Asarco Mine supplied coking coal to nearby coke ovens for Asarco smelters for 40 years until the mine closed in 1946 (Pillmore and others, 1999).

Coking coal from CF\&I's Allen (New Eagle) and Maxwell (Aztec) Mines several miles west of the town of Trinidad was used in coke ovens in Pueblo, Colorado, from the early 1950s until the late 1970s. However, the rise of electric steelmaking furnaces that do not require coke, and the closure of CF\&I's blast furnaces in Pueblo in the early 1980s, ended coking coal production in the Trinidad coal field (Pillmore and others, 1999; Gilbride and Ross, 2012). The New Eagle Mine continued to produce thermal coal for electrical plants until finally closing in the mid-1990s (Pillmore and others, 1999). Cline Mining Corp. of Toronto, Canada, purchased the New Eagle Mine (under the new name of New Elk) in the late 2000s and began an exploration drilling and laboratory analysis program in 2010, with plans for future production to supply coal to domestic and international clients for metallurgical and pulverized coal injection (PCI) use (Gilbride and Ross, 2012). There are multiple coal beds present in the New Elk Mine. Coal samples from the Green, Loco, Blue, 
Bing Canyon Upper, Red, Maxwell, Apache, and Allen coal beds in the New Elk Mine were low-sulfur, high-volatile B bituminous metallurgical-grade coal with average (ar) moisture content ranging from 2.5 to 4.1 percent, thermal content ranging from 9,100 to $12,140 \mathrm{Btu} / \mathrm{lb}$, ash yield ranging from 16.5 to 38.6 percent, and average total sulfur content ranging from 0.41 to 0.67 percent by weight, which was predominantly organic sulfur (Gilbride and Ross, 2012). After a brief period of production, operations at the New Elk Mine were idled. As of 2014, there were no mines operating in the Raton coal region in Colorado (Chris Carroll, Colorado Geological Survey, written commun., 2014).

\section{Coking Coals in New Mexico}

Coking coal is located in four coal fields in New Mexico: (1) the Raton coal field in Colfax County (locations 44 to 54 on figs. 2 and 7), (2) the Monero coal field of Rio Arriba County (location 55), (3) the Cerrillos coal field of Santa Fe County (location 56), and (4) the Carthage coal field of Socorro County (location 57) (Jones, 1915; Wells, 1930; Averitt, 1966; Elston, 1967; Mardirosian, 1979; Eveleth and Bieberman, 1983; Pillmore, 1991; Hoffman, 1991, 1993; Hoffman and Brister, 2003; Hoffman and Jones, 2005; Hoffman and Hereford, 2009).

The Raton coal field has been mined in at least ten coal mining districts: (1) the Yankee-Sugarite district (location 44 on figs. 2 and 7), (2) the Brilliant district (location 45), (3) the Gardiner-Blossburg district (location 46), (4) the Potato Canyon district (location 47), (5) the Upper York district (location 48), (6) the York Canyon (Ancho) district (location 49), (7) the Rosado district (location 50), (8) the Castle Rock district (location 51), (9) the Van Houten district (location 52), (10) the Koehler district (location 53), and (11) the Dawson district (location 54) (Hoffman and Jones, 2005). The earliest mining occurred in the Gardiner-Blossburg District just east of the town of Raton in the 1880s. Mines in this district extracted coals from the Upper Cretaceous Vermejo Formation. In the early 1900s, mining expanded into the Dawson, Van Houten, Brilliant, Koehler, and Yankee-Sugarite districts. Mines in all these districts, with the exception of the Yankee-Sugarite district, extracted coal from beds in the Vermejo Formation. Yankee-Sugarite district mines extracted coal beds in the Upper Cretaceous to Paleocene Raton Formation (overlying the Vermejo Formation). Coal from the Dawson district was used for coke in copper smelting plants in Arizona, steel mills in Colorado and Pennsylvania, and as locomotive fuel by the railroads (Hoffman, 1993). Many of these mines operated until the 1950s. Starting in 1955, coal from the Koehler district was used to make coke for the Kaiser Steel plant in Fontana, California (Hoffman and Jones, 2005). Kaiser also opened mines in the 1950s through 1970s in the York Canyon (Ancho), Upper York, Rosado, and Castle Rock districts. These mines extracted coal from beds in the upper coal zone of the Raton Formation. The 1983 closure of the Fontana steel mill resulted in the temporary cessation of mining in the
Raton coal field. In 1989, Pittsburg and Midway (Chevron) purchased and reopened the Kaiser mines to supply thermal coal to a Wisconsin power plant. By 1995 they had closed all but the Ancho mine, which remained in operation until 2002. As of 2005 there was no active coal mining in the Raton coal field (Hoffman and Jones, 2005).

Coals in the Vermejo Formation tend to be discontinuous and relatively thin. The lower Vermejo Formation includes numerous coal beds, including the Upper and Lower Vermejo coal beds. Most coals in the lower Vermejo Formation are less than $50 \mathrm{ft}$ from the contact with the underlying Trinidad Sandstone. Coals in the upper Vermejo coal zone occur 0 to $100 \mathrm{ft}$ below the basal sandstone of the Raton Formation.

Coals in the Raton Formation are also discontinuous and relatively thin. The lower coal zone of the Raton Formation lies in the Cretaceous part of the formation. The 6-ft Sugarite coal bed lies at the top of this zone. The upper coal zone of the Raton Formation includes several important coal beds with thicknesses greater than $10 \mathrm{ft}$. Pillmore (1991) described seven coal beds within the upper coal zone in the central and eastern parts of the Raton coal field, including the York Canyon, Upper Left Fork, Lower Left Fork, and the Lower Raton coal beds.

Coals in both the Vermejo and Raton Formations have low sulfur contents, moderate ash yields, and are high-volatile A to B bituminous in rank. Most are coking coals that have been used to make coke for metallurgical use. Sample analyses show that York Canyon coals have higher CV $(13,499$ Btu/lb) than Left Fork coals $(11,406 \mathrm{Btu} / \mathrm{lb})$, while Left Fork coals have lower total sulfur contents $(0.42$ percent $)$ than York Canyon coals ( 0.50 percent). Consequently, because the York Canyon coals are higher in $\mathrm{CV}$, the pounds of sulfur per million Btu is the same for both (0.37) (Hoffman and Jones, 2005).

The Monero coal field (location 55 on figs. 2 and 7) of Rio Arriba County, New Mexico, is on the northeastern side of the San Juan basin (Averitt, 1966; Hoffman, 1991). The Monero field includes three minable coal beds in the Gibson Coal Member of the Late Cretaceous Crevasse Canyon Formation (Averitt, 1966). Monero field coals were mined from a total of 40 mines near the towns of Monero and Lumberton from the 1880s until 1971 (Hoffman, 1991). The Monero coals are relatively thin but have high CVs and good coking properties. The average coal analysis for the Monero field indicates these coals have low moisture (3.07 percent), moderate ash yields (11.8 percent), and a rank of high-volatile A bituminous (Hoffman, 1991).

The Cerrillos coal field (location 56 on figs. 2 and 7) in Santa Fe County has three coal zones in the Late Cretaceous Mesaverde Group, probably within the Menefee Formation: (1) the Miller Gulch coal zone (bottom), (2) the Cook and White coal zone (middle), and (3) the White Ash coal zone (top) (Averitt, 1966; Beaumont, 1979). The upper two zones have been mined extensively. The lower zone contains coals that can be coked for metallurgical use, but most have been highly metamorphosed by nearby dikes and sills, rendering 
them unsatisfactory for coking (Averitt, 1966). Commercial mining began in the 1880s in the Miller and Waldo Gulches west of Cerrillos, and then moved east to Madrid Gulch, where the Colorado Fuel and Iron Company of Pueblo, Colorado, mined high-volatile bituminous coal that was blended with coking coal from Trinidad, Colorado (Beaumont, 1979). The mine at Madrid Gulch was acquired by the Albuquerque and Cerrillos Coal Company in 1906, which mined the area until 1947. The properties were then purchased by Oscar Huber, who continued operations until the last mine closed in 1958 (Beaumont, 1979). Cerrillos coals are mostly high-volatile bituminous, except where intrusions have raised the coal rank as high as anthracite (Hower and others, 2013).

The Carthage coal field (location 57 on figs. 2 and 7) of Socorro County, New Mexico, includes only one minable coal bed, the Carthage coal bed of the Late Cretaceous Dilco Coal Member of the Crevasse Canyon Formation (Hoffman, 2017). The coal is high-volatile A bituminous in rank with 3.7 percent moisture, 39.7 percent VM, 46.7 percent fixed carbon (FC), 9.9 percent ash, 1.0 percent sulfur, 2.2 percent air-dry loss (ADL), and a heating value of 12,860 Btu/lb (Averitt, 1966; Hoffman and Hereford, 2009). Carthage field coals were coked in nearby beehive ovens in the 19th century. Coal was mined in more than a dozen mines operated by numerous companies between the 1880s and the 1960s. Mining ceased in the Carthage field in 1968 (Hoffman and Hereford, 2009).

\section{Coking Coals in Oklahoma}

Coking coal can be found in two locations in Oklahoma, the small Henryetta district in Okmulgee County (location 58 on figs. 2 and 8) (Dunham and Trumbull, 1955), and the southern part of the Oklahoma coal field in the Arkoma basin in Atoka, Coal, Haskell, Latimer, Le Flore, McIntosh, Muskogee, Okfuskee, Okmulgee, Pittsburg, and Sequoyah Counties (location 59 on figs. 2 and 8) (Hendricks and others, 1937; Knechtel, 1949; Trumbull, 1957; Averitt, 1966). In the Henryetta district and the southwestern part of the Oklahoma coal field, the rocks are only moderately deformed, and the coal rank is high-volatile bituminous. Further east in the Oklahoma coal field, deformation was greater and the coal is medium- to low-volatile bituminous in rank. Some high- to medium-volatile bituminous coal from Oklahoma can be used to make coke, but the low-volatile bituminous coal can only be used for blends with coals of lower rank (Averitt, 1966).

The Henryetta district in Okmulgee County (location 58 on figs. 2 and 8 ) is only 10 square miles in area, but it has been very extensively mined (Davis and Reynolds, 1941; Dunham and Trumbull, 1955). Most of the production came from the Croweburg (Henryetta) coal bed of the Pennsylvanian Senora Formation of the Cabaniss Group. The Croweburg bed ranges from 25 - to 41.5 -in. thick and is generally 36 -in. thick over most of its area. The Mineral (Morris) coal bed, occurring about $125 \mathrm{ft}$ below the Croweburg bed, has been mined locally, but it is thin (averaging about 16-in. thick). Both beds are high-volatile B bituminous coal. In 1952, coal from the Croweburg bed was used in blends for making coke at the Sheffield steel plant of Houston, Texas (Dunham and Trumbull, 1955), and although the coke was not as strong as coke from eastern coals, it is probably suitable for making blast furnace coke. A blend of 80 percent Croweburg coal and 20 percent low-volatile bituminous Lower Hartshorne coal from the southern part of the Oklahoma coal field yields a coke with greatly improved strength (Averitt, 1966).

Coking coal occurs in the southern part of the Oklahoma coal field (location 59 on figs. 2 and 8) in the Arkoma basin in Atoka, Coal, Haskell, Latimer, Le Flore, McIntosh, Muskogee, Okfuskee, Okmulgee, Pittsburg, and Sequoyah Counties, Oklahoma (Hendricks and others, 1937; Knechtel, 1949; Trumbull, 1957; Averitt, 1966). At least seven mineable Pennsylvanian coal beds are present. The most important ones are the Lower and Upper Hartshorne and the McAlester (Stigler) coal beds. Coals from these beds are low in sulfur, ash, and inherent moisture and have heating values between 13,000 to $15,000 \mathrm{Btu} / \mathrm{lb}$ on an air-dried basis (Knechtel, 1949). Other coal beds, including the Secor, Lower Witteville, and Cavanal beds, are generally too thin (less than 12 in.) and too high in sulfur and ash to be of interest as a metallurgical coal product (Knechtel, 1949; Averitt, 1966). The Lower Hartshorne bed in the Pennsylvanian Hartshorne Formation of the Krebs Group ranges from 0.8- to $7 \mathrm{ft}$-thick and averages about 4-ft thick (Oklahoma Mining Commission Department of Mines, 2016). The Upper Hartshorne coal, also in the Pennsylvanian Hartshorne Formation, ranges from 2- to 4-ft thick (Oklahoma Mining Commission Department of Mines, 2016). In the northern part of the coal field, the Upper and Lower Hartshorne coal beds become a single bed 1- to 7-ft thick called the Hartshorne coal bed (Trumbull, 1957; Andrews and others, 1998; Oklahoma Mining Commission Department of Mines, 2016). In Haskell and Le Flore Counties, the Hartshorne bed is 3- to 7-ft thick and is an excellent coking coal (Oklahoma Mining Commission Department of Mines, 2016). The McAlester coal in the middle of the McAlester Formation, ranges in thickness from 1.75 to $4 \mathrm{ft}$ with an average thickness of about $3.5 \mathrm{ft}$ where it is mined, although it is less than 2.5 - $\mathrm{ft}$ thick over much of its area (Averitt, 1966). Trumbull (1957) uses the name Stigler coal in Sequoyah County, Oklahoma, for a bed that is correlative with the McAlester coal. Coals of the southern Oklahoma coal field increase in rank from west to east from high-volatile C bituminous to low-volatile bituminous (Cardott, 2013; Oklahoma Mining Commission Department of Mines, 2016). Coke has been made from washed slack coal (very fine coal or coal dust) from the McAlester and Hartshorne beds in the McAlester district in the western part of the Oklahoma field. Washed, this very fine coal product contains 2.59 percent VM, 85.33 percent carbon, 11.12 percent ash, 0.04 percent phosphorus, and 1.75 percent sulfur (Hendricks and others, 1937). Forty ovens were in operation between 1900 and 1905 to make coke from Lower Hartshorne coal in the town of Howe in Le Flore County. Lower Hartshorne coal is not used alone to make coke because it expands and damages the walls 


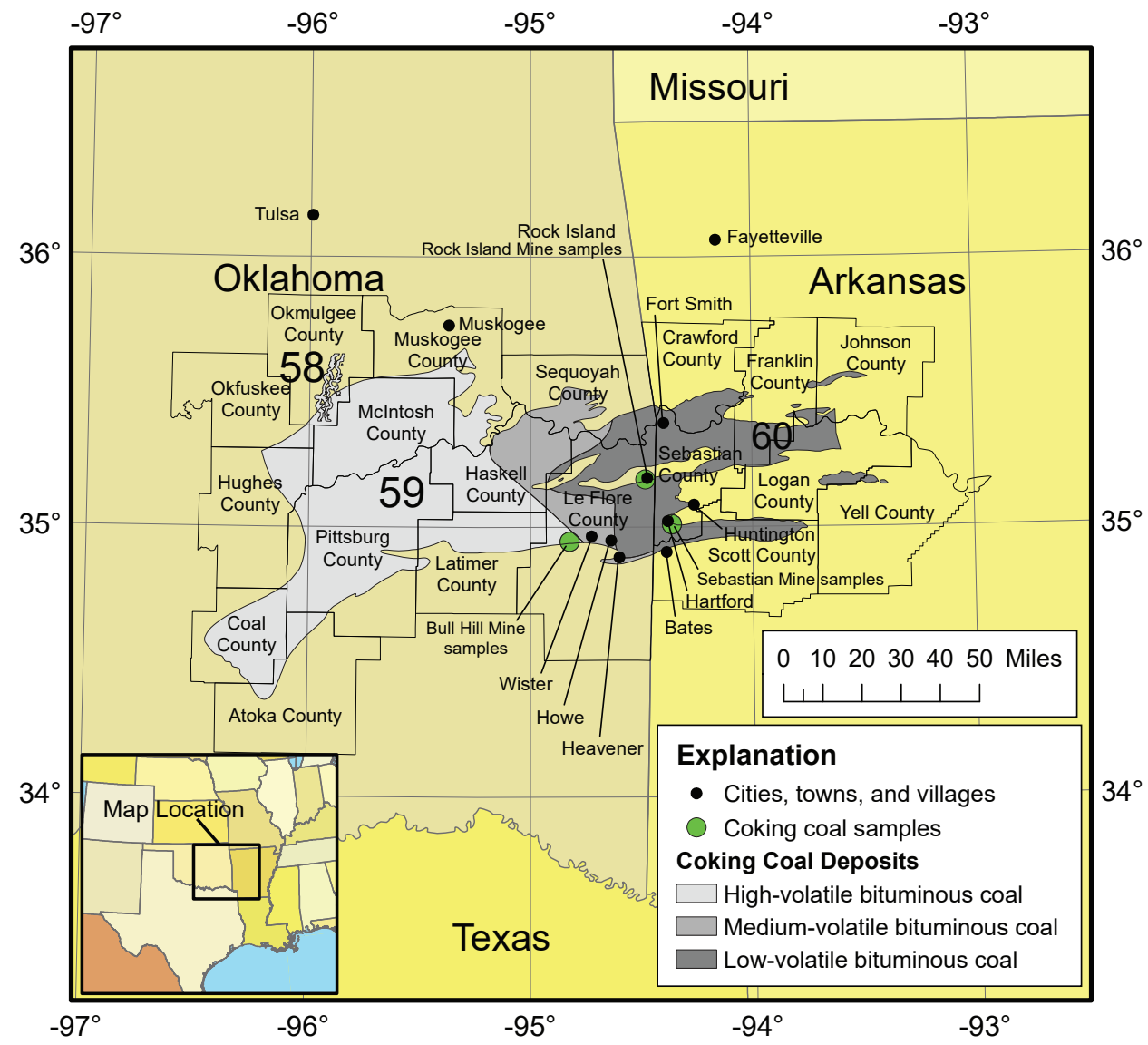

Figure 8. Map showing the locations of bituminous coking coal deposits in the States of Oklahoma and Arkansas. Numbers 58 to 60 correspond to coking coal deposit locations identified in the text and appendix 1 (table 1.1). The green-filled circles are the locations of the three coking coal samples from Bull Hill and Rock Island Mines in Le Flore County, Oklahoma, discussed in the text; sample analyses results are provided in appendixes 2 to 7 (tables 2.1 to 7.1). These data can also be downloaded from https://doi.org/10.5066/P9KFQOKM.

of by-product ovens. Analyses of samples of McAlester coal from Pittsburg County as well as Lower Hartshorne coal from Le Flore County showed that McAlester coal alone yielded a very weak coke. A blend of 30 percent Lower Hartshorne and 70 percent McAlester coal created a relatively high-sulfur coke with increased specific gravity, size, and stability (Davis and Reynolds, 1942) that stayed within the parameters set for blast furnaces because of its low ash-softening temperature. High-volatile bituminous coal from the western part of the field contracts during coking, resulting in coke of low crushing strength, which is unusable in blast furnaces (Knechtel, 1949).

Low-volatile bituminous coal from eastern Oklahoma has been blended with high-volatile bituminous coals and used in coke ovens in Provo, Utah; Fontana, California; and Houston and Daingerfield, Texas (Knechtel, 1949; Averitt, 1966). Trumbull (1957) classified these coal resources by township, bed, bed thickness, rank, and other categories.
Prior to 1960 , coals exhibiting steep dips (18 degrees to 65 degrees) were commonly mined in the southern part of the Oklahoma coal field. Between 1960 and 1974, it was not profitable to mine these steeply-dipping coal beds and the mines were idled. After the Arab oil embargo of 1973, mining resumed at seven surface mines in 1974 and continued until 1984, producing coking and metallurgical coal with low sulfur content (1 percent). After 1984, the mines were again idled as a decrease in coal prices made mining unprofitable (Oklahoma Mining Commission Department of Mines, 2016).

In 2012, Ouro Mining and the Texas and Oklahoma Coal Company began planning a metallurgical coal mine in Le Flore County near Heavener, Oklahoma (Bradbury, 2014; Coppock, 2015; Ouro Mining, Inc., 2016; Texas and Oklahoma Coal Company, 2016). However, falling coking coal prices in late 2014 put this project on hold at least temporarily (Fort Smith Times Record, 2014; Layden, 2014). The 
project planned to ship coal by truck, railroad, and (or) river barge to New Orleans, Louisiana; Port Arthur, Texas; and other ports, where it would be transloaded to ships headed to Asian steel mills. As of March 1, 2018, the project appears to be on hold as the company website has not been updated since 2015.

In 2016, there were only three active coal mines in the southern part of the Oklahoma coal field, two in Le Flore County producing a combined total of 525,120 tons of coal from the Hartshorne coal bed, and one in Haskell County producing only 829 tons from the Stigler coal bed. A fourth coal mine in the Henryetta coal field in Okmulgee County produced 1,375 tons of coal from the Croweburg (Metropolis) coal bed (Oklahoma Department of Mines, 2018).

The U.S. Energy Information Administration (2018b) reported a total of 0.394 million short tons (mst) of thermal bituminous coal produced from three mines in Le Flore (2) and Okmulgee (1) Counties, Oklahoma, in 2017 (appendix 9A). From this total, $0.319 \mathrm{mst}$ came from one underground mine, and $0.075 \mathrm{mst}$ came from two surface mines. They indicated that none of this coal was used for metallurgical purposes (appendix 9B).

Three samples of coking coal from two mines in Le Flore County were collected in 2014 by Brian Cardott of the Oklahoma Geological Survey and were analyzed for this project. One sample came from the Lower Hartshorne bed in the Rock Island Mine, and the remaining two samples came from the Upper and Lower Hartshorne beds in the Bull Hill Mine. The results of the analyses of these three samples are listed in the appendixes and discussed in the "Samples Collected and Analyzed for This Report" and "Discussion of Results" sections of this report. Point locations for the three samples are shown on fig. 8. These data can also be downloaded from https://doi.org/10.5066/P9KFQOKM.

\section{Coking Coals in Arkansas}

West-central Arkansas coal is low-volatile bituminous in rank, but at the east end of the Arkansas Valley field (location 60 on figs. 2 and 8 ) the coal has attained semi-anthracite rank. The low-volatile bituminous coal can be used to make coke in blends with coals of lower rank, but the semi-anthracite cannot be used for coking (Averitt, 1966). Coal produced from Franklin, Johnson, Logan, Scott, and Sebastian Counties, Arkansas, comes from the Lower and Upper Hartshorne coal beds of the Pennsylvanian McAlester Formation and from the Charleston and Paris coal beds of the Pennsylvanian Savanna Formation (Haley, 1954).

The Lower Hartshorne coal bed at the base of the McAlester Formation has been the largest producer of coal in Arkansas (Haley, 1954). Lower Hartshorne Coal in the Arkansas Valley coal field was used for manufacturing metallurgical coke for blast furnaces in Colorado, Ohio, Pennsylvania, Texas, and Japan for 115 years, but since 1985 has only been used for electrical power generation (Oklahoma
Mining Commission Department of Mines, 2016). The coal bed is more than 8-ft thick in an area west of Huntington in Sebastian County (Haley, 1954).

The Upper Hartshorne bed has a maximum thickness of about $34 \mathrm{in}$. and is of low-volatile bituminous rank (Haley, 1954).

The Charleston coal bed is more than 14-in. thick over a large area and attains a maximum thickness of about 23 in. In the western part of the Arkansas Valley coal field, the Charleston bed is of low-volatile bituminous rank, but it grades into semi-anthracite in the eastern part of the field. In Franklin and Johnson Counties, the Charleston coal bed is locally called the Philpott coal bed (Haley, 1954).

The Paris coal bed is only present in three small areas of Franklin and Logan Counties (Haley, 1954). It ranges in thickness from 14 to $32 \mathrm{in}$. and is of low-volatile bituminous rank (Haley, 1954).

A blend of low and high-volatile bituminous coal produces a coke of good quality and high yield per ton of coal. Because of the rapid expansion of the western steel industry after World War II, increasing quantities of low-volatile bituminous coal from Arkansas were shipped to Colorado, Utah, California, and Texas for use in coking coal blends (Haley, 1954).

In 2013, there were only two active coal mines in Arkansas, including the Ouro mine, near the town of Bates in Scott County, Arkansas, which supplies coking coal for steel making from the Lower Hartshorne coal bed (Chandler, 2013).

The U.S. Energy Information Administration (2018b) reported a total of $0.043 \mathrm{mst}$ of thermal and (or) coking bituminous coal produced from three mines in Sebastian County, Arkansas, in 2017 (appendix 9A). From this total, 0.024 mst came from one underground mine, and 0.019 mst came from two surface mines. They did not indicate in their report how much of the coal was used for metallurgical and nonmetallurgical purposes.

Three samples of coking coal from Arkansas were collected by Bill Prior of the Arkansas State Geological Survey and were analyzed for this project. All three samples came from the Lower Hartshorne bed in the Sebastian Mine representing the lower $24 \mathrm{in}$., middle $20 \mathrm{in}$., and upper $24 \mathrm{in}$. of the bed. The results of the analyses of these three samples are listed in appendix 2 to 7 and discussed in the "Samples Collected and Analyzed for This Report" and "Discussion of Results" sections of this report. A point location for the three samples is shown on fig. 8. These data can also be downloaded from https://doi.org/10.5066/P9KFQOKM.

\section{Coking Coals in the Illinois basin}

Coal deposits in the Illinois basin are in central and southern Illinois, southwestern Indiana (locations 61 to 63, respectively, on figs. 2 and 9), and western Kentucky. Although coking coals in these States were mined in the early and middle 20th Century, currently no Indiana or Kentucky 
coking coals are being mined, and Illinois coking coals have only been used in blends with other coals from the Appalachian basin for metallurgical purposes.

\section{Coking Coals in Illinois}

Illinois coals are generally not considered suitable for use alone as metallurgical coal although several coals from Illinois (location 61 on figs. 2 and 9) have been used in blends with other coals to make good coking coals (Reed and others, 1952; Jackman and others, 1956; Jackman and others, 1959). During and after World War II, southern Illinois coal was sent to byproduct ovens in Chicago and Granite City, Illinois, (fig. 9) to make domestic and metallurgical coke (U.S. Bureau of Mines, 1942). In the late 1930s, coke for domestic use was created using Curran-Knowles ovens in West Frankfort and Millstadt, Illinois, (fig. 9), but the vast majority of coke produced from by-product and beehive ovens in Illinois (95.7 percent in 1937) came from Appalachian coals in West Virginia, Kentucky, Pennsylvania, and Virginia, with only a small amount (4.3 percent in 1937) from Illinois coals (U.S. Bureau of Mines, 1942).

Most coking coal from the Illinois basin comes from the southern region where coal rank is mostly high-volatile $\mathrm{B}$ bituminous, except for a small area of high-volatile A bituminous in southern Gallatin, Saline, Williamson, and Jackson Counties (Jackman and Helfinstine, 1967; Treworgy and others, 1997) (fig. 9). Central Illinois coals are either high-volatile B and $\mathrm{C}$ bituminous, and coals from northern Illinois are mostly high-volatile C bituminous (Jackman and Helfinstine, 1967; Treworgy and others, 1997).

High-volatile A bituminous coal from the No. 6 (Herrin) bed of the Pennsylvanian Carbondale Formation (Treworgy and others, 1997) was blended with low-volatile bituminous coal from the Pocahontas No. 3 bed of the Pennsylvanian Pocahontas Formation in Virginia and West Virginia in the

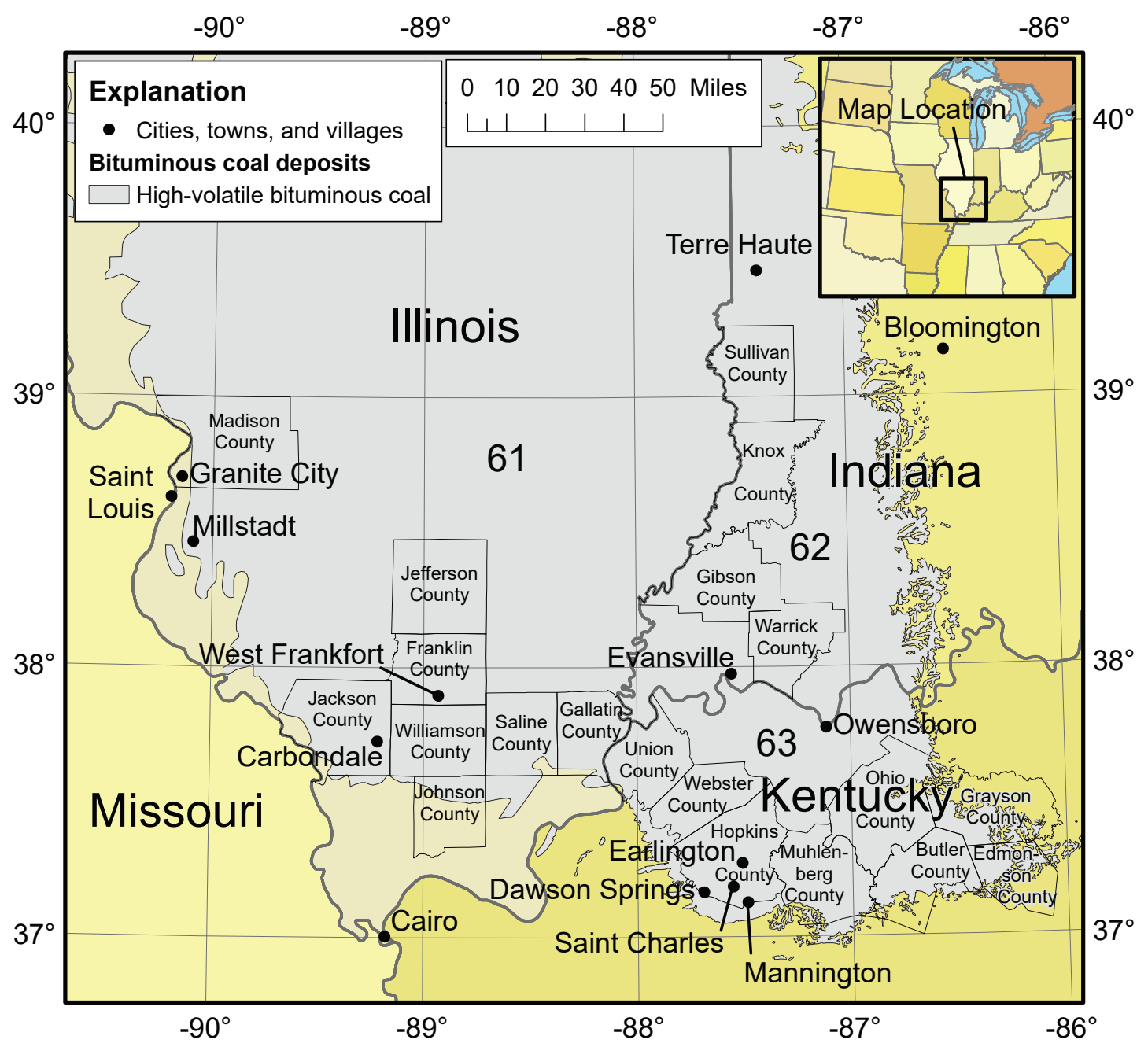

Figure 9. Map showing the locations of high-volatile, bituminous coal deposits in the States of Illinois, Indiana, and western Kentucky in the Illinois basin coal region. Numbers 61 to 63 correspond to coking coal deposit locations identified in the text and appendix 1 (table 1.1). 
1940s and 1950s to produce blast furnace coke by the Koppers Company plant at Granite City, Illinois (Jackman and others, 1956) (fig. 9). The No. 5 (Springfield) bed, also from the Carbondale Formation (Treworgy and others, 1997), was also used in blends with the No. 6 and Pocahontas coals at the Koppers Company plant and a Chicago area coke plant in the late 1940s and 1950s (Jackman and others, 1956). The resulting coke had improved surface structure, stability, and relatively small coke size (Jackman and others, 1956). Blends of No. 6, No. 5, and Pocahontas coals with medium-volatile bituminous coals from four Appalachian basin beds (the Sewell bed in West Virginia and Virginia, the Tiller and Jewell (Raven) beds in Virginia, and the Bradshaw bed in West Virginia, all from the Pennsylvanian New River Formation) also yielded satisfactory coke (Jackman and others, 1959). High-volatile bituminous Appalachian basin coals from the Eagle and No. 2 Gas beds (both from the Pennsylvanian Kanawha Formation in West Virginia), and the "B" (Kellioka or Van Lear) and "C" (Upper Elkhorn No. 3 or Nosben) beds (of the Pennsylvanian Pikeville Formation of the Breathitt Group in Kentucky) were also successfully used as a third constituent in some blends (Jackman and others, 1959).

High-volatile $\mathrm{C}$ bituminous Illinois coals from the No. 2 (Colchester bed of the Carbondale Formation [Treworgy and others, 1997]), No. 6 (Herrin) bed, and No. 7 (Danville) bed of the Pennsylvanian Shelburn Formation of the McLeansboro Group (Treworgy and others, 1997) in northern and central Illinois are high in moisture, VM, and sulfur, and have low FSI values (Jackman and Helfinstine, 1967). They yield cokes with low stability and high sulfur content when coked alone, but when they are blended with medium-volatile bituminous coal from the Jewell bed or low-volatile bituminous coal from the Beckley bed (from the New River Formation of West Virginia) and Pocahontas No. 3, stability increases and sulfur content decreases. However, because sulfur contents remain above one percent (sometimes greater than three percent), these coals are still not considered good for metallurgical use and were not being used to make metallurgical coke in 1967.

Lower sulfur coal from the No. 6 bed has been mined in south-central Madison County in southwest Illinois (Jackman and Helfinstine, 1967) (fig. 9). It made poor coke when used alone and in blends with low-volatile bituminous Pocahontas coals and other Illinois coals (the No. 5, and No. 6 from other southern Illinois locations), but when Pocahontas coals were replaced with medium-volatile bituminous coals from the Jewell bed, strong cokes were obtained. Similar results were obtained with other high-sulfur content No. 6 bed coals from southwest Illinois.

Based on total thermal and metallurgical coal production, in 2017, 52,120 mst of Herrin coal was produced in the Illinois basin (in Illinois, Indiana, and Kentucky), with 50,451 mst from underground mines and $1.669 \mathrm{mst}$ from surface mines (U.S. Energy Information Administration, 2018b, appendix 9C). They also reported that mined thicknesses ranged from 43 to 86 in., with an average of 74 in.
High-volatile B bituminous coals from the No. 5 and No. 6 beds from Jefferson, Franklin, Williamson, and Saline Counties were the only Illinois coals used commercially for metallurgical and chemical coke prior to 1967 (Jackman and Helfinstine, 1967) (fig. 9). Coal from the No. 5 bed makes stronger coke than coal from the No. 6 bed, but overall it has higher sulfur content than the No. 6 coals. Blends of both beds with (1) low-volatile bituminous coals from the Beckley and Pocahontas (No. 3 and 4) beds, (2) mediumvolatile bituminous coals from the Jewell, Sewell (of the New River Formation in West Virginia), Pocahontas No. 3, and Splashdam (of the Norton Formation in Virginia) beds, and (3) high-volatile bituminous coal from the Powellton (of the Kanawha Formation in West Virginia) bed yielded strong cokes for blast furnace and chemical use. Inland Steel also mined the No. 5 bed for metallurgical purposes at their Inland No. 2 Mine in Hamilton County for a short period, but the mine was taken over by CONSOL and later closed (John Popp, geologist, written commun., 2019).

Four more high-volatile A bituminous beds in southern Illinois have been tested for their coking potential and were found to yield strong cokes both alone and in blends with Illinois No. 6 and Pocahontas coals, but most also had high sulfur content (Jackman and Helfinstine, 1967). These beds include (in descending order) (1) the Davis and Dekoven beds (of the Carbondale Formation) in Williamson and Saline Counties, (2) the Willis bed (of the Pennsylvanian Tradewater Formation) in Gallatin County, and (3) the Reynoldsburg bed (also of the Tradewater Formation) in Johnson County (formation names from Treworgy and others, 1997) (fig. 9). Some Reynoldsburg coal samples exhibited sulfur content as low as 0.52 percent, but other samples had greater than two percent.

Inland Steel Company began using metallurgical-grade high-volatile coal from the No. 6 bed from its Inland No. 1 coal mine in Jefferson County, Illinois, in 1968 (Kaegi and Osterman, 1980; bed identity confirmed from Myers and Chenoweth, 2008). In the 1970s, Illinois basin coal was commonly used in blends to make metallurgical coke for Midwestern steel companies (Kramer and others, 2011). In 1980, the Inland No. 1 mine produced $2.5 \mathrm{mst}$, with about 70 percent used for metallurgical coke (Kaegi and Osterman, 1980). Blends of 60 percent or more of Illinois coal with 40 percent or less of medium-volatile coal from Virginia, West Virginia, and (or) Pennsylvania were used in Inland furnaces with smaller diameter hearths (20 to $27 \mathrm{ft}$ ) in 1980 (Kaegi and Osterman, 1980). However, new larger furnaces that became more common in the late 1970 s required coke with higher CSR values than Illinois coals can provide, so the use of these coals to make metallurgical coke was discontinued (Kramer and others, 2008, 2011). Kramer and others (2008, 2011) proposed that Illinois basin coal be blended with Appalachian basin coal to make coke and pyrolysis gases for the generation of electricity, and the production of liquid transportation fuels (using Fischer-Tropsch processes), fertilizer, and (or) hydrogen. 
The U.S. Energy Information Administration (2018b) reported a total of 48.204 mst of thermal bituminous coal produced from 18 mines in eleven counties in central and southern Illinois in 2017 (appendix 9A). From this total, $44.906 \mathrm{mst}$ came from ten underground mines, and $3.298 \mathrm{mst}$ came from eight surface mines (appendix 9A). The largest producers were Franklin, Williamson, Washington, Hamilton, and Saline Counties with $12.812 \mathrm{mst}, 6.336 \mathrm{mst}, 6.202 \mathrm{mst}$, $6.129 \mathrm{mst}$, and $4.552 \mathrm{mst}$, respectively (appendix 9A). Their report indicated that none of the coal produced in Illinois in 2017 was used for metallurgical purposes (U.S. Energy Information Administration, 2018b) (appendix 9B).

In 2017, the Herrin (Illinois No. 6, Western Kentucky No. 11) coal bed was the most productive coal bed in the Illinois basin (in Illinois, Indiana, and Kentucky), and the third most productive bed in the United States after the Wyodak bed in Wyoming and the Pittsburgh bed in the Northern Appalachian basin, with 52.120 mst produced (U.S. Energy Information Administration, 2018b) (appendix 9C). From this total, $50.451 \mathrm{mst}$ came from underground mines and $1.669 \mathrm{mst}$ came from surface mines (appendix 9C). Mined thicknesses ranged from 43 to 86 in., with an average of 74 in. (appendix 9C).

In 2017, the Springfield (Illinois No. 5, Western Kentucky No. 9) coal bed was the second most productive coal bed in the Illinois basin (from all three States), and the fourth most productive bed in the United States after the Wyodak, Pittsburgh, and Herrin beds, with 37.059 mst produced (U.S. Energy Information Administration, 2018b) (appendix 9C). From this total, $29.152 \mathrm{mst}$ came from underground mines and $7.907 \mathrm{mst}$ came from surface mines (appendix 9C). Mined thicknesses ranged from 24 to $80 \mathrm{in}$., with an average of 66 in. (appendix 9C).

\section{Coking Coals in Indiana}

Coal beds in the Pennsylvanian Brazil Formation of western Indiana (location 62 on figs. 2 and 9) were used to make coke as early as the 1870s (Valia and Mastalerz, 2004). Blending the Upper and Lower Block coals with coal from the Connellsville district of Pennsylvania (Fayette County) was found to make a good coke that put less pressure on oven walls. Miller (1967) reported that all Indiana coals were relatively high in sulfur, making them unsatisfactory for coking. In the 1990s, Inland Ispat in Gary, Indiana, began using the Block coals in blends to take advantage of their high strengths and contraction properties (Valia and Mastalerz, 2004). The Upper and Lower Block coals and other Indiana coals, for example, (1) the Danville and Hymera coals of the Dugger Formation of the Carbondale Group, (2) the Springfield coal of the Petersburg Formation of the Carbondale Group, (3) the Colchester coal of the Linton Formation of the Carbondale Group, and (4) an unnamed coal of the Mansfield Formation (1-4 all Pennsylvanian in age) have suitable properties for pulverized coal injection (PCI) in blast furnaces (Valia and Mastalerz, 2004). In 2004, no Indiana coals were being used for coke blends or PCI (Valia and Mastalerz, 2004).
The U.S. Energy Information Administration (2018b) reported a total of $31.472 \mathrm{mst}$ of thermal bituminous coal produced from 18 mines in eight counties in southwestern Indiana in 2017 (appendix 9A). From this total, $14.396 \mathrm{mst}$ came from four underground mines, and $17.076 \mathrm{mst}$ came from 14 surface mines. The largest producers were Gibson, Sullivan, Knox, and Warrick Counties with $10.116 \mathrm{mst}, 7.435 \mathrm{mst}, 6.231 \mathrm{mst}$, and $4.237 \mathrm{mst}$, respectively (appendix 9A). Their report indicated that none of the coal produced in Indiana in 2017 was used for metallurgical purposes (U.S. Energy Information Administration, 2018b) (appendix 9B).

As already described in the Illinois coking coal section above, the U.S. Energy Information Administration (2018b) reported production amounts and bed thicknesses of the Herrin and Springfield coals in the Illinois basin (in Illinois, Indiana, and Kentucky) in 2017 (appendix 9C). See the Illinois coking coal section above and appendix $9 \mathrm{C}$ for more information.

\section{Coking Coals in Western Kentucky}

Coking of Western Kentucky (location 63 on figs. 2 and 9) coal began in the 1880s (Allen, 1888; Kentucky Coal Association and Kentucky Geological Survey, 2011). The St. Bernard Coal Company coked the No. 9 (Springfield) and the No. 11 (Herrin) coals of the Middle Pennsylvanian Carbondale Formation in Hopkins County, Kentucky, in 1882 , but were unsatisfied with the resulting coke which was high in sulfur. Hutchinson (1912) reported that the No. 11 (Herrin) coal bed of the Middle Pennsylvanian Carbondale Formation yielded excellent coke in large quantities for years from the St. Bernard Mines near Earlington, Kentucky. Glenn (1912) believed the No. 1b (Bell) coal bed of the Lower Pennsylvanian Caseyville Formation held promise for future use in metallurgical coke-making because of its low ash, sulfur, and phosphorus, and high calorific value, compared to other Western Kentucky coals. Allen (1888) described the "L" (probably the Bell) coal bed mined at Mannington, Kentucky, as yielding a coke with excellent structure with slightly elevated sulfur. The "L" bed was also being extensively developed in Edmonson, Grayson, and Butler Counties (Allen, 1888). Palmer (1969) and Donan (1969) reported that coal from the No. 4 (Mannington) coal bed of the Middle Pennsylvanian Tradewater Formation in the Rialto Mine near St. Charles, Kentucky, and the Williams Mine near Mannington, Kentucky, was used to produce high-grade chemical coke at the Chemical Coke Company plant near Dawson Springs, Kentucky. Currently there is no western Kentucky coal being used for coking (Kentucky Coal Association and Kentucky Geological Survey, 2011).

The U.S. Energy Information Administration (2018b) reported a total of 23.606 mst of thermal bituminous coal produced from 13 mines in seven counties in western Kentucky in 2017 (appendix 9A). From this total, $21.553 \mathrm{mst}$ came from seven underground mines, and $2.053 \mathrm{mst}$ came from six surface mines (appendix 9A). The largest producers were Union, Ohio, Hopkins, and Muhlenberg Counties with 
$8.962 \mathrm{mst}, 4.126 \mathrm{mst}, 3.576 \mathrm{mst}$, and $2.777 \mathrm{mst}$, respectively (appendix 9A). Their report indicated that none of the coal produced in western Kentucky in 2017 was used for metallurgical purposes (U.S. Energy Information Administration, 2018b) (appendix 9B).

As already described in the Illinois coking coal section above, the U.S. Energy Information Administration (2018b) reported production amounts and bed thicknesses of the Herrin and Springfield coals in the Illinois basin (in Illinois, Indiana, and Kentucky) in 2017 (U.S. Energy Information Administration, 2018b) (appendix 9C). See the Illinois coking coal section above and appendix 9C for more information.

The Kentucky Energy and Environment Cabinet (2019) reported a total of $22.664 \mathrm{mst}$ of coal produced from seven counties in western Kentucky in 2018 (appendix 10A). The five highest producers were Union, Hopkins, Ohio, Muhlenberg, and Webster Counties with totals of $9.753 \mathrm{mst}$, $3.540 \mathrm{mst}, 2.738 \mathrm{mst}, 2.630 \mathrm{mst}$, and $2.476 \mathrm{mst}$, respectively (Kentucky Energy and Environment Cabinet, 2019) (appendix 10A). Of the total $22.664 \mathrm{mst}, 21.988 \mathrm{mst}$ came from underground mines and $0.677 \mathrm{mst}$ came from surface mines (appendix 10B).

\section{Coking Coals in the Appalachian Basin}

There are over one hundred coal beds in the Appalachian basin that exhibit metallurgical coal properties (figs. 2, 10, 11, and 12). In general, most of the coal beds are medium-volatile bituminous in rank, but their rank tends to increase eastward in the basin (figs. 2 and 10) (Ruppert and others, 2014). Unfortunately, there are very few maps available showing the full extents of these coal beds. For this reason, the extent of bituminous coal in the Appalachian basin is shown rather than the extents of numerous individual coal beds in specific States in the basin. In the 1940s and 1950s, the USBM published reports with maps of coking coal extents in 43 counties in the Appalachian basin including Kentucky (6 counties), Maryland (1), Pennsylvania (12), Tennessee (13), and West Virginia (11); however, other counties where coking coal was produced were not included in this series (Dowd and others, 1950a, b, 1951a-e, 1952a-c, 1955a, b, 1956; Wallace and others, 1952, 1953a-e, 1954a-d, 1955a, b; Williams and others, 1954, 1955a-d, 1956a-c; Blaylock and others, 1955, 1956; Hershey and others, 1955, 1956a-c; Lowe and others, 1956; Provost and others, 1956; Tavenner and others, 1956; Travis and others, 1956; Williams and Hershey, 1956). Details of these reports are summarized in this study, but the maps within the reports were not digitized because they show only the extents of the coal beds within the county on which they report.

Coal bed extents of the Pittsburgh, Upper Freeport, Pocahontas No. 3, Fire Clay, and Pond Creek coal beds were created by the USGS for the resource assessments of these beds. The maps from these assessments are available at https://pubs.usgs.gov/pp/1708/ii/pdf/pp1708_I1 pdf.pdf (Trippi and others, 2014b).
The West Virginia Geologic and Economic Survey (WVGES) has posted coal bed extent maps for about 60 coal beds in West Virginia on their website at http://www.wvgs.wvnet.edu/ www/coal/cbmp/coalimsframe.html.

The Kentucky Geological Survey (KGS) published a report about metallurgical coal resources of Kentucky including maps showing the original and remaining resources from the Fire Clay, Upper Elkhorn No. 3, Upper Elkhorn No. 2, Lower Elkhorn, Clintwood, Glamorgan, Hagy, and Splash Dam coal beds, and maps of structure contours, overburden thickness, and outcrop extent of the Lower Elkhorn coal bed in Kentucky (Eble and Weisenfluh, 2013). The report can be downloaded from the KGS website at https://kgs.uky.edu/ kgsweb/olops/pub/kgs/CNR57_12.pdf.

A report showing the extents of six coal beds in the Warrior coal field of Alabama was published by Winston (1990) (Winston actually uses the term "Warrior coal basin" for this area; see the discussion in the Warrior coal field section below for more details). The report can be purchased from the Alabama Geological Survey. Details are available at https://www.gsa.state.al.us/ogb/publications/C152/.

A correlation chart showing the stratigraphic relationship of coal beds and (or) zones, rock formations, and key stratigraphic units of the Appalachian basin for the States of Alabama, Tennessee, Kentucky, Virginia, West Virginia, Ohio, Maryland, and Pennsylvania was published by Ruppert and others (2014), and can be accessed at https://pubs.usgs.gov/pp/ 1708/d2/pdf/pp1708_d2.pdf. This chart is useful in understanding the regional stratigraphic relationships between coal beds in the Appalachian basin that are discussed herein. Also included in this report is a brief summary of the geology of the Appalachian basin, including the coal fields, coal production, and Pennsylvanian stratigraphy of the basin.

Maps showing the distribution of coal fields, coal beds, and coalbed methane fields in the Appalachian and Black Warrior basins were completed by Trippi and others (2014a) and can be accessed at https://pubs.usgs.gov/pp/1708/d1/pdf/ pp1708_d1.pdf.

\section{Coking Coals in the Northern Appalachian Basin Coal Region}

The Northern Appalachian basin coal region (Trippi and others, 2014a) includes parts of the States of Pennsylvania, Ohio, Maryland, and West Virginia (locations 64 to 67, respectively, on figs. 2 and 10). A series of county coking coal reports by the USBM in the 1940s and 1950s identified 17 coal beds in the Northern Appalachian basin coal region that have coking properties including, in descending stratigraphic order: the Washington and Waynesburg coal beds of the lower Permian to upper Pennsylvanian Dunkard Group; the Sewickley, Redstone, and Pittsburgh coal beds of the Upper Pennsylvanian Monongahela Group; the Barton, Harlem, Upper Bakerstown, Lower Bakerstown, and Mahoning coal beds of the Upper to Middle Pennsylvanian Conemaugh 


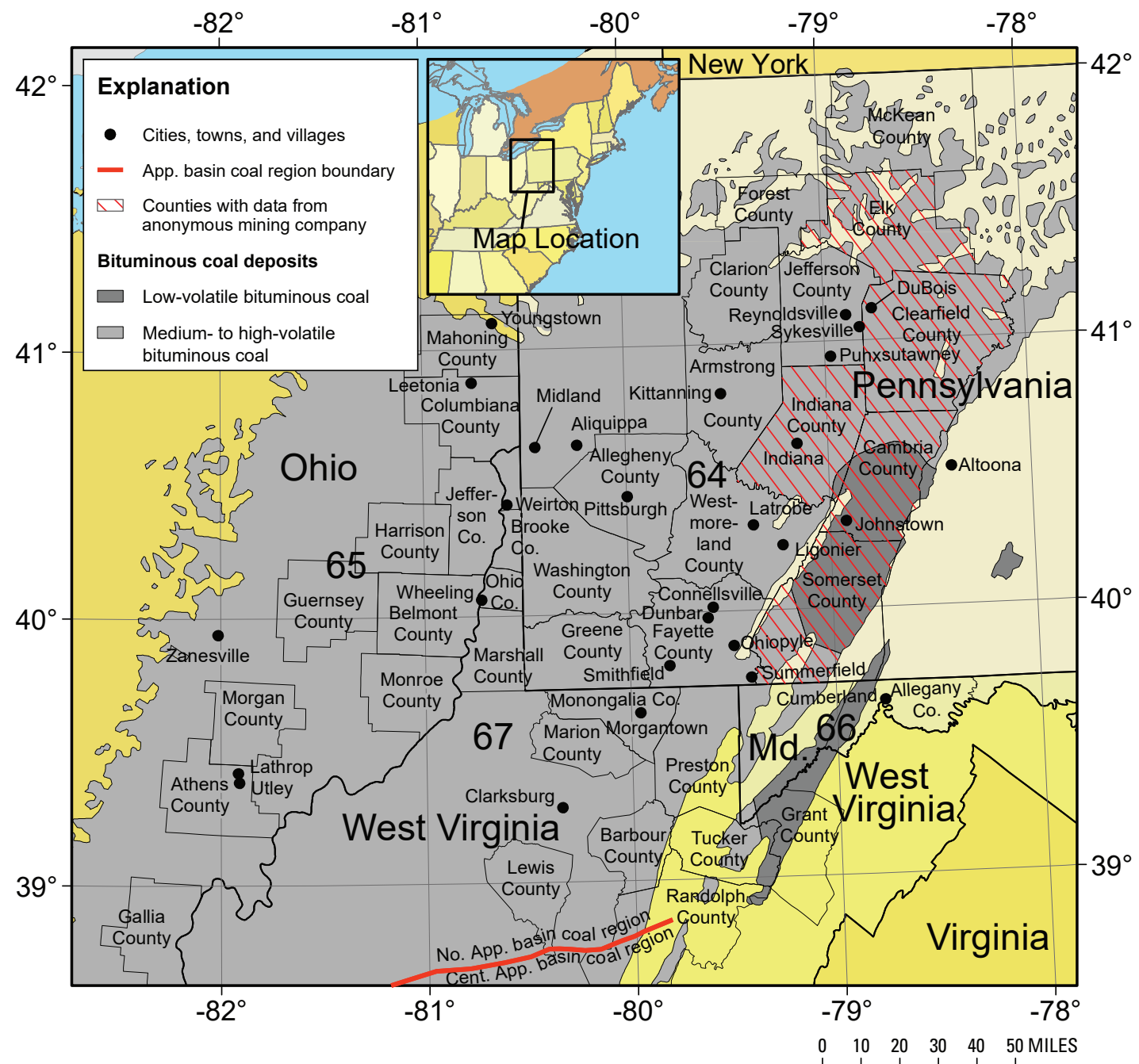

Figure 10. Map showing the locations of bituminous coal deposits in the States of Ohio, Pennsylvania, Maryland, and West Virginia in the Northern Appalachian basin coal region. Numbers 64 to 67 correspond to coking coal areas identified in the text and appendix 1 (table 1.1). Abbreviations: App., Appalachian; Cent. App., Central Appalachian; Co., County; Med., Medium; No. App., Northern Appalachian.

Group; and the Upper Freeport, Lower Freeport, Upper Kittanning, Middle Kittanning, Lower Kittanning, Clarion, and Brookville coal beds of the Middle Pennsylvanian Allegheny Group or Allegheny Formation (Dowd and others, 1950a, b; 1951a, b, e; 1952a; 1955a, b; 1956; Wallace and others, 1953a, b, e; 1955a, b; Blaylock and others, 1955, 1956; Provost and others, 1956; Travis and others, 1956). The most important of these coal beds is the Pittsburgh, followed by the Upper Freeport, Lower Kittanning, Upper Kittanning, and Sewickley. Some of the remaining beds discussed in these reports have been used for making coke, while others exhibit coking properties but have never been used to make coke.

The U.S. Energy Information Administration (2018b) reported a total of 47.219 mst of thermal and (or) coking bituminous coal produced from 96 mines in 16 counties in Pennsylvania in 2017 (appendix 9A). From this total,
43.510 mst were produced from 29 underground mines, and 3.709 mst came from 67 surface mines. The largest producers were Greene, Washington, Somerset, and Indiana Counties with $29.287 \mathrm{mst}, 9.182 \mathrm{mst}, 2.172 \mathrm{mst}$, and $2.112 \mathrm{mst}$, respectively (appendix 9A). They reported $6.129 \mathrm{mst}$ as metallurgical coal and $32.021 \mathrm{mst}$ as non-metallurgical coal in 2017 (appendix 9B). The Pennsylvania Department of Environmental Protection (2018) reported a similar total of 49.347 mst of thermal and coking bituminous coal from 142 mines in 2017 (appendixes 11A and 11B). (Note that totals from the U.S. Energy Information Administration usually do not exactly match totals from State agencies.) From their total, 43.785 mst came from 30 underground mines (appendixes $11 \mathrm{C}$ and 11D), and $5.562 \mathrm{mst}$ came from 112 surface mines (appendixes $11 \mathrm{E}$ and $11 \mathrm{~F}$ ). They report the largest producers as Greene, Indiana, Somerset, and Armstrong Counties with 
38.717, 2.556, 2.369, and $1.614 \mathrm{mst}$, respectively (appendix $11 \mathrm{~A}$ and 11B). It is puzzling that the Pennsylvania Department of Environmental Protection (2018) reported no underground mine production in Washington County in 2017, while the U.S. Energy Information Administration (2018b) reported $9.182 \mathrm{mst}$ of coal production for the same year. We suspect that data for Washington County underground mines may have been turned in after completion of the Pennsylvanian Department of Environmental Protection report, but before the U.S. Energy Information Administration report.

In northern West Virginia, the U.S. Energy Information Administration (2018b) reported 46.754 mst of thermal and coking coal produced from 15 mines in nine counties in 2017, including 11 underground mines producing $46.608 \mathrm{mst}$, and four surface mines producing $0.147 \mathrm{mst}$ (appendix 9A). The largest producers were Marshall, Marion, Ohio, Taylor, and Tucker Counties with 17.700 mst, 13.368 mst, 6.988 mst, $3.381 \mathrm{mst}$, and $2.114 \mathrm{mst}$, respectively (appendix 9A). They reported $4.090 \mathrm{mst}$ as metallurgical coal and $41.188 \mathrm{mst}$ as non-metallurgical coal in 2017 (appendix 9B). The West Virginia Office of Miners' Health, Safety and Training (2018) did not categorize their data based on northern and southern regions, so it is unclear in several counties that straddle the boundary between the two regions which data belong to which region. We were therefore unable to report the total production in northern West Virginia using their report.

In Ohio, the U.S. Energy Information Administration (2018b) reported 9.489 mst of thermal coal produced from 18 mines in nine counties in 2017, with 6.801 mst coming from seven underground mines, and $2.688 \mathrm{mst}$ from 11 surface mines (appendix 9A). The largest producers were Monroe and Harrison Counties with $5.677 \mathrm{mst}$ and $1.674 \mathrm{mst}$, respectively (appendix 9A). Their report indicated that none of the coal produced in Ohio in 2017 was used for metallurgical purposes (U.S. Energy Information Administration, 2018b) (appendix 9B). Wright and Stucker (2018) reported a similar total of $10.271 \mathrm{mst}$ of thermal and coking bituminous coal from 13 counties in Ohio in 2017 (appendix 12). They reported the largest producers as Belmont, Harrison, and Perry Counties with $6.107 \mathrm{mst}, 2.068 \mathrm{mst}$, and $1.179 \mathrm{mst}$, respectively (appendix 12). It is puzzling that Wright and Stucker (2018) reported no underground mine production in Monroe County in 2017, while the U.S. Energy Information Administration reported $10.271 \mathrm{mst}$ of coal production for the same year. We suspect that data for Monroe County may have been turned in after completion of the Wright and Stucker report, but before the U.S. Energy Information Administration report was begun.

Finally, in Maryland the U.S. Energy Information Administration (2018b) reported $1.808 \mathrm{mst}$ of thermal and coking coal produced from 14 mines in Allegany and Garrett Counties, Maryland, in 2017, with 0.744 mst coming from two underground mines, and $1.064 \mathrm{mst}$ coming from 12 surface mines (appendix 9A). Garrett County was the largest producer with $1.136 \mathrm{mst}$, followed by Allegany County with $0.673 \mathrm{mst}$ (appendix 9A). They reported $0.897 \mathrm{mst}$ as metallurgical coal and 0.733 mst as non-metallurgical coal in 2017 (appendix 9B). The Maryland Bureau of Mines (2017) reported a total of $2.023 \mathrm{mst}$ of thermal and coking bituminous coal from Allegany and Garrett Counties, Maryland, in 2016 (appendix 13A). From their total, $1.098 \mathrm{mst}$ came from 2 underground mines, and $0.925 \mathrm{mst}$ came from 53 surface mines (appendixes 13A and 13B). The largest producer was Garrett County with $1.098 \mathrm{mst}$ from two underground mines, and $0.293 \mathrm{mst}$ from 17 surface mines (appendixes 13A and 13B).

Analytical data from thirteen samples of coking coal from Pennsylvania were shared with the USGS by an anonymous mining company in Pennsylvania. Five samples came from mines in Indiana County, three each came from mines in Somerset and Cambria Counties, and one each came from Elk and Clearfield Counties (the company requested that we show the location of samples only by county name). The results of the analyses of these thirteen samples are listed in appendixes 2 to 8 and discussed in the "Sample Data From Other Sources" and "Discussion of Results" sections of this report. These data can also be downloaded from https://doi.org/10.5066/P9KFQOKM. Locations of these counties are shown on fig. 10.

\section{Washington (No. 12 in Ohio) coal bed}

The Washington coal bed is the stratigraphically youngest commercially mined coking coal bed in the Northern Appalachian basin coal region. It is located at the base of the Washington Formation of the Upper Pennsylvanian and lower Permian Dunkard Group. In Washington County, Pennsylvania (fig. 10) the Washington coal bed ranges from 52- to 100-in. thick with two to four benches separated by one to three partings that make up 6 to 18 in. of the total thickness (Wallace and others, 1955b). In West Virginia, the Washington coal bed is no longer considered part of the resource base (Mitch Blake, West Virginia Geological and Economic Survey, written commun., 2018).

The Washington coal bed is high-volatile A bituminous in rank (Dowd and others, 1955a, b, 1956; Wallace and others, 1955b; Provost and others, 1956; Travis and others, 1956). Dowd and others (1955a, b, 1956) note the coal was utilized for metallurgical coke if blended with higher rank coals, but in Brooke, Marshall, and Ohio Counties, West Virginia, the Washington coal is high in ash yield and sulfur content and makes poor coke. In Marion and Monongalia Counties, West Virginia, Provost and others (1956) and Travis and others (1956) report the Washington coal bed was generally not used for coke making.

Six USBM county coking coal reports described the Washington coal as a bed of lesser to minor importance in Washington County, Pennsylvania, and Brooke, Marion, Marshall, Monongalia, and Ohio Counties, West Virginia (fig. 10) (Dowd and others, 1955a, b, 1956; Wallace and others, 1955b; Provost and others, 1956; Travis and others, 1956). 
No Washington coal was produced in Pennsylvania, Ohio, or West Virginia in 2017, or in Maryland in 2016 (Pennsylvania Department of Environmental Protection, 2018; Wright and Stucker, 2018; West Virginia Office of Miners' Health, Safety and Training, 2018; Maryland Bureau of Mines, 2017).

\section{Waynesburg (No. 11 in Ohio) coal bed}

The Waynesburg coal bed is the second youngest commercially mined coking coal bed in the Northern Appalachian basin coal region. It is located below the Washington coal bed at the base of the Upper Pennsylvanian and lower Permian Dunkard Group. In central Fayette County, Pennsylvania (fig. 10), the Waynesburg coal bed's thickness ranges from 24 to 54 in., and locally contains a parting that is 2- to 18 -in. thick in the middle part of the bed (Hickok and Moyer, 1940). In the western part of Fayette County, the Waynesburg coal bed is commonly separated into three benches, with the top bench often consisting of bone coal, the middle bench clean coal (without parting), and the bottom bench hard "dirty" coal (Hickok and Moyer, 1940). In Greene County, Pennsylvania, the Waynesburg coal bed's thickness ranges from 30 to 94 in. and contains up to five partings ranging in thickness from 1 to $30 \mathrm{in}$. (Wallace and others, 1955a). In central and western Greene County, the Waynesburg coal bed typically has two benches (Brian Shaffer, U.S. Geological Survey, written commun., 2019). The bottom bench is usually 3 - to 5 - $\mathrm{ft}$ thick, while the top bench is usually 1 - to 2 -ft thick. A bed of argillaceous clay shale, 10 - to 15 -in. thick, typically separates the benches. The upper bench rarely contains carbonaceous clay shale partings that split the bench into multiple thin coal beds (Brian Shaffer, U.S. Geological Survey, written commun., 2019).

The Waynesburg coal is mainly high-volatile A bituminous in rank, but in Allegany County, Maryland, it is lowvolatile bituminous (Dowd and others, 1951b, e, 1955a, b, 1956; Wallace and others, 1953e, 1955a, b; Provost and others, 1956; Travis and others, 1956). Dowd and others (1955a, b, 1956) and Wallace and others (1955a) note that the coal was used to make metallurgical coke if blended with higher rank coals (or in Allegany County, Maryland, if blended with lower rank coals). In Greene County, Pennsylvania, and Brooke, Marshall, and Ohio Counties, West Virginia, they note the Waynesburg coal bed is high in ash yield and sulfur content, making it a poor choice for coke making. In Marion and Monongalia Counties, West Virginia, the Waynesburg coal bed was generally not used for coke making (Provost and others, 1956; Travis and others, 1956).

Ten USBM county coking coal reports described the Waynesburg coal bed as a bed of lesser to minor importance in Allegany County, Maryland; Fayette, Greene, Washington, and Westmoreland Counties, Pennsylvania; and Brooke, Marion, Marshall, Monongalia, and Ohio Counties, West Virginia (fig. 10; Dowd and others, 1951b, e, 1955a, b, 1956; Wallace and others, 1953e, 1955a, b; Provost and others, 1956; Travis and others, 1956).

Two surface mines in Greene and Washington Counties, Pennsylvania, produced $0.013 \mathrm{mst}$ of Waynesburg coal in 2017 (appendixes 11E and 11F) (Pennsylvania Department of Environmental Protection, 2018).

In 2017, in Belmont County, Ohio, 0.012 mst of Waynesburg coal was produced (Wright and Stucker, 2018) (appendix 12).

No Waynesburg coal was produced in Maryland in 2016 or West Virginia in 2017 (Maryland Bureau of Mines, 2017; West Virginia Office of Miners' Health, Safety and Training, 2018).

\section{Sewickley (Meigs Creek or No. 9 in Ohio, Tyson in Maryland) coal bed}

The Sewickley coal bed is located below the Waynesburg coal bed in the Upper Pennsylvanian Monongahela Group. In Fayette County, Pennsylvania (fig. 10), the Sewickley coal bed ranges from 30- to 78-in. thick with an average of about 60 in. (Hickok and Moyer, 1940). It commonly has two to three benches separated by partings that range from a few inches up to $35 \mathrm{ft}$ (Hickok and Moyer, 1940). The top 2- to 6-in. is generally composed of bone coal, and thin shale and pyrite partings that are present throughout the bed tend to raise the sulfur content and ash yield (Hickok and Moyer, 1940). In southern Somerset County, Pennsylvania, the lower bench of the Sewickley coal is 12- to 18-in. thick (Flint, 1965). In central Greene County, Pennsylvania, and Monongalia County, West Virginia, the Sewickley coal bed is a single bench ranging from 5- to 7-ft thick (Brian Shaffer, written commun., 2019). In some locations, it can be thicker and brighter than the underlying Pittsburgh coal. North, west, and east of central Greene County, the Sewickley has two benches separated by sandstones and sandy silt shales. The upper bench is 2- to 4-ft thick, while the lower bench is usually $<1$ - $\mathrm{ft}$ thick. In some locations, the lower bench is only an impure coal or carbonaceous clay shale. The parting ranges from carbonaceous clay shale (1- to 2 -in. thick) to massively bedded sandstone (30-ft thick or more). In older publications, coal beds identified as the Sewickley in Fayette and Washington Counties, Pennsylvania, may actually be only the upper bench of the Sewickley (Brian Shaffer, written commun., 2019). In the same publications, beds identified as the Fishpot coal bed may actually be the lower bench of the Sewickley. Generally, the two Sewickley benches are separated by clastics, while the lower split of the Sewickley and the Fishpot are separated by 12 to $15 \mathrm{ft}$ of freshwater limestone (Brian Shaffer, written commun., 2019).

The Sewickley coal is high-volatile A bituminous in rank in most locations, except in Allegany County, Maryland, where it is low-volatile bituminous (Dowd and others, 1951b, 1955b, 1956; Wallace and others, 1953e, 1955a, b; Provost and others, 1956; Travis and others, 1956). It can be used to 
make metallurgical coke if blended with higher rank coals (except in Allegany County where it should be blended with lower rank coals), but in Marshall and Ohio Counties, West Virginia, the Sewickley coal has high ash yield and sulfur content making it a poor choice for coke making (Dowd and others, 1955b, 1956). In Marion County, West Virginia, the Sewickley coal bed is not used for coke making (Provost and others, 1956).

Eight USBM county coking coal reports described the Sewickley coal bed as an important coal bed in Fayette County, Pennsylvania; and Monongalia County, West Virginia; and a bed of lesser to minor importance in Allegany County, Maryland; Greene and Washington Counties, Pennsylvania; and Marion, Marshall, and Ohio Counties, West Virginia (fig. 10) (Dowd and others, 1951b, 1955b, 1956; Wallace and others, 1953e, 1955a, b; Provost and others, 1956; Travis and others, 1956).

In 2017, 1.939 mst of coal from the Sewickley bed was produced from two underground mines in Greene County, Pennsylvania (Pennsylvania Department of Environmental Protection, 2018) (appendixes 11C and 11D). One surface mine in Indiana County, Pennsylvania, produced $0.073 \mathrm{mst}$ of Sewickley coal in 2017 (appendixes 11E and 11F); five other surface mines in Fayette (3) and Somerset Counties (2), Pennsylvania, reported Sewickley coal as part of aggregate production of multiple beds, so we were unable to determine the exact amount of Sewickley coal produced in those mines (Pennsylvania Department of Environmental Protection, 2018).

In 2017, $0.793 \mathrm{mst}$ of Sewickley (Meigs Creek or No. 9) coal was produced in Belmont, Harrison, Noble, and Washington Counties, Ohio (Wright and Stucker, 2018) (appendix 12).

In 2016, 0.089 mst of Sewickley and (or) Tyson coal was produced from six surface mines in Allegany (5) and Garrett (1) Counties, Maryland (Maryland Bureau of Mines, 2017) (appendix 13).

In 2017, 0.275 mst of Sewickley coal was produced from one underground mine in Monongalia County, West Virginia (West Virginia Office of Miners' Health, Safety and Training, 2018) (appendix 14).

\section{Redstone (Pomeroy or No. 8A in Ohio) coal bed}

The Redstone coal bed is located below the Sewickley coal bed in the Upper Pennsylvanian Monongahela Group. In northeast Fayette County, Pennsylvania (fig. 10), the Redstone coal bed ranges from 20- to 48-in. thick, and it tends to be clean (without parting) and sometimes is separated into two benches by a parting near the middle of the bed (Hickok and Moyer, 1940). In southern Somerset County, Pennsylvania, the minable part of the Redstone is about 44-in. thick (Flint, 1965), but thins southwestward to about 1- to 2-ft. In Greene County, Pennsylvania, the Redstone coal bed is approximately $40 \mathrm{ft}$ above the Pittsburgh coal bed and approximately $40 \mathrm{ft}$ below the Sewickley coal bed or the bottom split of the
Sewickley coal bed. It is 8- to 12 -in. thick in central Greene County, and thickens to $>3 \mathrm{ft}$ to the south near Morgantown, West Virginia. North and east of central Greene County, the Redstone thins and often becomes a 1- to 2-in. thick carbonaceous clay shale. It is almost always overlain by 2 to $3 \mathrm{ft}$ of gray-green claystone with slickensides.

The Redstone coal is high-volatile A bituminous in rank in most locations (Dowd and others, 1951b, 1951e; Wallace and others, 1953a, b, 1955b; Provost and others, 1956). They note the coal can be used to make metallurgical coke if blended with higher rank coals. In Marion County, West Virginia, the Sewickley coal bed was not used for coke making (Provost and others, 1956).

Six USBM county coking coal reports described the Redstone coal as a bed of lesser to minor importance in Allegheny, Fayette, Somerset, Washington, and Westmoreland Counties, Pennsylvania, and Marion County, West Virginia (fig. 10) (Dowd and others, 1951b, e; Wallace and others, 1953a, b, 1955b; Provost and others, 1956).

Three surface mines in Westmoreland County, Pennsylvania, produced $0.804 \mathrm{mst}$ of Redstone coal in 2017 (appendixes 11E and 11F); seven other surface mines in Fayette (3) and Somerset (4) Counties, Pennsylvania, produced Redstone coal in 2017 as part of aggregate production of multiple beds, so we were unable to determine the exact amount of Redstone coal produced in these mines (Pennsylvania Department of Environmental Protection, 2018).

In 2017, 0.312 mst of Redstone (Pomeroy or No. 8a) coal was produced in Harrison County, Ohio (Wright and Stucker, 2018) (appendix 12).

In 2016, 0.246 mst of Redstone coal was produced from twelve surface mines in Allegany (11) and Garrett (1) Counties, Maryland (Maryland Bureau of Mines, 2017) (appendix 13).

No Redstone coal was produced in West Virginia in 2017 (West Virginia Office of Miners' Health, Safety and Training, 2018).

\section{Pittsburgh (No. 8 in Ohio) coal bed}

The Pittsburgh coal bed is at the base of the Upper Pennsylvanian Monongahela Group. The Pittsburgh coal bed ranges from a few inches up to $23 \mathrm{ft}$ in thickness and is divided into two parts: the upper "roof," and the lower "main bench" (White, 1891; Tewalt and others, 2001). The "roof" contains multiple partings that render it unsuitable for mining, whereas the minable "main bench" is low in ash yield and contains only one to three minor partings (Repine and others, 1993; Tewalt and others, 2001). In southern Somerset County, Pennsylvania, Flint (1965) describes the Pittsburgh as commonly 9- to 10-ft thick (Flint, 1965), with two distinct facies, a southwestern "Big Vein" facies ranging from 6- to $10.5-\mathrm{ft}$ thick, and a northeastern "Pine Hill \#2" facies that is about 4-ft thick. In Greene County, Pennsylvania, the Pittsburgh coal bed consists of a main bed with an overlying rider sequence. 
The main bed is 4.5 - to 8.5 -ft thick, and typically exhibits two 1-in. thick carbonaceous clay or dark-gray clay shale partings near the middle of the bed ("middle partings" or "finger partings," in local vernacular) (Brian Shaffer, written commun., 2019). The lower parting is typically about $40 \mathrm{in}$. above the base of the bed, and the upper parting is usually 2 to 3 in. above the lower parting. The rider (or "roof") coal sequence is usually 4 - to 6 - $\mathrm{ft}$ thick and consists of 3 to 5 coal beds, ranging from 4 - to 18 -in. thick, interbedded with gray to dark-gray argillaceous or carbonaceous clay shale partings. Typically, the main bed is separated from the rider sequence by 10 to $14 \mathrm{in}$. of brownish-gray to dark-gray argillaceous clay shale known to miners as "draw rock" or "drawslate" (Brian Shaffer, U.S. Geological Survey, written commun., 2019). The "drawslate" is friable, contains slickensides, and swells when exposed to moisture or air, making it spall-out around roof bolts. For this reason, the "drawslate" is generally removed during the mining process. In northern Greene County and central to eastern Washington County, the main bed is overlain by sandstones, shales, and sandy shales, and the rider coal bed sequence becomes irregular in continuity, possibly from displacement or erosion by fluvial paleochannels (Brian Shaffer, U.S. Geological Survey, written commun., 2019). In some locations, the main bed is abnormally thick (up to $18-\mathrm{ft}$ thick in one location) or totally removed as a result of faulting or plastic deformation of the unlithified plant material under the weight of the overlying clastic sediments (Brian Shaffer, U.S. Geological Survey, written commun., 2019).

The Pittsburgh coal is high-volatile A bituminous in rank in most locations, but low-volatile bituminous in Allegany County, Maryland, and low- to medium-volatile bituminous in Somerset County, Pennsylvania (Dowd and others, 1951b, e, 1955a, b, 1956; Wallace and others, 1953a, b, 1955a, b; Provost and others, 1956; Travis and others, 1956). Dowd and others (1955a, b, 1956) report the Pittsburgh coal makes good metallurgical coke if blended with higher rank coals (or blended with lower rank coals in Allegany County, Maryland, and Somerset County, Pennsylvania) (It should be noted that the Pittsburgh bed has since been mined-out in these two counties [John Popp, geologist, written commun., 2019]). In Brooke, Marshall, and Ohio Counties, West Virginia, they note the Pittsburgh coal is high in ash yield and sulfur content, making it a poor choice for metallurgical coke making. Repine and others (1993) report a median total-sulfur content of 2.2 percent, median ash yield of 6.5 percent, and a median heating value of 13,900 Btu/lb for the Pittsburgh coal bed in West Virginia. In some locations, the best coal (low in ash and sulfur) was mostly mined-out and Dowd and others (1950a, 1951b, 1951e) and Wallace and others (1955a) note that the remaining coal may require cleaning to remove ash and (or) sulfur before coking, primarily in Fayette, Greene, Indiana, and Westmoreland Counties, Pennsylvania. In the early 1950s, the Pittsburgh coal exhibited excellent quality and thickness in Washington County, Pennsylvania, with most mining in areas near the surface in the eastern and northern parts of the county (Wallace and others, 1955b). But since the 1990s, the areas in eastern Washington County have been mined-out, and the focus of mining has shifted to the central and western parts of Washington County where the Pittsburgh coal is mined in the subsurface using deep longwall mining methods (Brian Shaffer, U.S. Geological Survey, written commun., 2019). Currently, Pittsburgh coal is mined in the Bailey/Enlow Fork/Harvey mining complex in southwestern Washington County, the largest deep mine complex in the United States (Brian Shaffer, U.S. Geological Survey, written commun., 2019). Contura Coal's Cumberland Mine complex in central Greene County ranks just behind the Bailey/Enlow Fork/ Harvey complex in production (Brian Shaffer, U.S. Geological Survey, written commun., 2019). Likewise, surface mining of the Pittsburgh coal in the 1950s in Marion and Monongalia Counties, West Virginia, near the Monongahela River, ended in the 1990s, and the focus of mining has shifted to the west in subsurface mines like Federal 2, Robinson Run, and Blacksville 2 Mines (Brian Shaffer, U.S. Geological Survey, written commun., 2019). Pittsburgh coal from Marion and Monongalia Counties, West Virginia, was generally too high in volatiles to make a good coke by itself, but when blended with medium- and low-volatile bituminous coals like the Pocahontas No. 3 and Pocahontas No. 4 coals (from southern West Virginia and southwestern Virginia) a much better coke is reported (Provost and others, 1956; Travis and others, 1956). The Pittsburgh is a strongly coking, low-volatile, bituminous coal with low sulfur content in Allegany County, Maryland (Wallace and others, 1953e).

Historically, the Pittsburgh coal bed was one of the earliest coals used for coking purposes in the United States (Hickok and Moyer, 1940). Details of the historical Pittsburgh coal mining in the Connellsville and Klondike coke districts of Pennsylvania can be found in appendix 18. The Pittsburgh coal bed, which is mined for both thermal and metallurgical purposes, is one of the best coking coals in the Northern Appalachian basin coal region and the United States. In 2017, the Pittsburgh coal bed was the most productive coal bed in the Northern Appalachian basin coal region, and the second most productive bed in the United States after the Wyodak in Wyoming, with 111.233 mst produced (U.S. Energy Information Administration, 2018b) (appendix 9C). For production in 2017, $108.133 \mathrm{mst}$ came from underground mines and $3.090 \mathrm{mst}$ came from surface mines (appendix 9C). The minimum and maximum thicknesses produced in 2017 were 18 and 108 in., respectively (U.S. Energy Information Administration, 2018b) (appendix 9C).

The Pennsylvania Department of Environmental Protection (2018) reported production of $36.769 \mathrm{mst}$ of coal from the Pittsburgh bed from five underground mines in Greene County, Pennsylvania, in 2017, with Consol's Bailey Deep Mine, Enlow Fork, and Harvey Mines responsible for 71 percent of the total, and Consol's Cumberland Mine responsible for another 26 percent (appendixes 11C and 11D). Four surface mines in Fayette (1), Indiana (2), and Westmoreland (1) Counties, Pennsylvania, produced 0.081 mst of Pittsburgh coal in 2017 (appendixes 11E and 
11F); six other surface mines in Fayette (2) and Somerset (4) Counties reported production of Pittsburgh coal as part of aggregate production of multiple beds, so we were unable to determine the exact amount of Pittsburgh coal produced in those mines (Pennsylvania Department of Environmental Protection, 2018).

The Ohio Department of Natural Resources reported production of 6.987 mst of Pittsburgh (No. 8) coal in Belmont and Harrison Counties, Ohio in 2017 (Wright and Stucker, 2018) (appendix 12).

The Maryland Bureau of Mines (2017) reported production of 0.306 mst of Pittsburgh coal from twelve surface mines in Allegany (9) and Garrett (3) Counties, Maryland, in 2016 (appendix 13).

The West Virginia Office of Miners' Health, Safety and Training (2018) reported production of $50.401 \mathrm{mst}$ of Pittsburgh coal from seven underground mines in Marion (2), Marshall (2), Monongalia (2), and Ohio (1) Counties, West Virginia, in 2017 (appendix 14). One surface mine in Monongalia County, West Virginia, produced $0.011 \mathrm{mst}$ of Pittsburgh coal in 2017.

In eastern Ohio (location 65 on figs. 2 and 10) the Pittsburgh coal bed was coked in at least three locations, Utley and Lathrop in Athens County, and Bridgeport in Belmont County (Bownocker and others, 1908; Bownocker and Dean, 1929). Utley coke was shipped to Cleveland, Cincinnati, Toledo, Chicago, and other cities, but in the early 20th century coke production in Athens County was abandoned because the remaining coal had sulfur contents that were too high (greater than four percent) to make good coke. The Pittsburgh coal bed is high in sulfur in most eastern Ohio locations including Gallia, Athens, Morgan, and southwestern Belmont Counties. However, in northeast Belmont County, southeast Harrison County, and southwest Jefferson County, Bownocker and others (1908) noted the sulfur content is lower (2 to 3 percent), and after washing the coal, a high-quality coke with less than one percent sulfur can be made. Brian Shaffer of the U.S. Geological Survey (written commun., 2019) has noted that in areas where the Redstone limestone is present, the underlying Pittsburgh coal bed is generally higher in sulfur content, possibly due to the leaching of pyrite from the freshwater limestone. However, in areas where the Pittsburgh is overlain by clastic sequences from fluvial paleochannels, its sulfur content is generally lower. The fluvial sediments may provide a buffer to the leaching of pyrite from the overlying freshwater limestones. Also, in paleochannel areas, which were subaerially exposed during deposition of the limestones, the limestone is thin or weathered to a gray or gray-green claystone, so the amount of pyrite available for leaching may be lower (Brian Shaffer, U.S. Geological Survey, written commun., 2019).

Eleven USBM county coking coal reports described the Pittsburgh coal bed as an important coking coal in Allegheny, Fayette, Greene, Somerset, Washington, and Westmoreland Counties of Pennsylvania and in Brooke, Marion, Marshall, Monongalia, and Ohio Counties of West Virginia (fig. 10)
(Dowd and others, 1951b, e, 1955a, b, 1956; Wallace and others, 1953a, b, 1955a, b; Provost and others, 1956; Travis and others, 1956). The Pittsburgh was of lesser importance in Allegany County, Maryland, and Armstrong County, Pennsylvania (mostly mined-out), and Indiana County, Pennsylvania, (very little present) (Dowd and others, 1950a, 1951a; Wallace and others, 1953e). Most of the mining of the Pittsburgh coal bed in the 19th century occurred in Fayette and Westmoreland Counties, Pennsylvania, but these USBM reports note that in the late 1940 s and early 1950 s the coal in these counties had been mostly mined-out, leaving Greene and Washington Counties, Pennsylvania, with the largest remaining Pittsburgh coal bed resources. In Cambria, Clarion, Clearfield, and Jefferson Counties, the Pittsburgh was either absent, or of such minor importance that it was not mentioned in USBM county reports. In 1951, the Pittsburgh coal bed was the highest producing bed in Allegany County, Maryland, with 146,428 net tons; however, by 1953 it was mostly mined-out (Wallace and others, 1953e).

\section{Barton (Elk Lick in Pennsylvania and West Virginia), Upper Bakerstown, Lower Bakerstown (Anderson in Ohio), and Mahoning (No. 7A in Ohio) coal beds}

The Barton, Upper Bakerstown, Lower Bakerstown, and Mahoning coal beds, in descending stratigraphic order are part of the mostly Upper Pennsylvanian Conemaugh Group. The Barton coal bed is in the Casselman Formation of the Conemaugh Group, while the Upper and Lower Bakerstown coal beds and the Mahoning coal bed are in the Glenshaw Formation. The Mahoning coal is the only Middle Pennsylvanian coal in the Conemaugh Group. These coal beds are not major sources of coking coal in the Appalachian basin. Wallace, and others (1953e) listed the Barton, Upper Bakerstown, and Lower Bakerstown coal beds as of lesser to minor importance in Allegany County, Maryland (fig. 10). The Mahoning coal bed was listed as a bed of minor importance for coking in Jefferson County, Pennsylvania.

In 2016, 0.190 mst of Barton coal was produced from one underground mine in Garrett County, Maryland, and two surface mines in Garrett County produced 0.063 mst of Barton coal (Maryland Bureau of Mines, 2017) (appendix 13). No Barton coal was produced in Pennsylvania, Ohio, or West Virginia in 2017 (Pennsylvania Department of Environmental Protection, 2018; West Virginia Office of Miners' Health, Safety and Training, 2018; Wright and Stucker, 2018).

Three surface mines in Somerset County, Pennsylvania, produced an unknown amount of Upper Bakerstown coal in 2017; these mines reported aggregate production for multiple beds, so we were unable to determine the exact amount of Upper Bakerstown coal produced (Pennsylvania Department of Environmental Protection, 2018). In 2016, 0.007 mst of "Bakerstown" coal was produced from two surface mines in Garrett County, Maryland (Maryland Bureau of Mines, 2017) (appendix 13). It is unclear from the Maryland Bureau of Mines report if the "Bakerstown" bed is equivalent to the 
Upper Bakerstown, the Lower Bakerstown, or both. No Upper Bakerstown was produced in Ohio or West Virginia in 2017 (West Virginia Office of Miners' Health, Safety and Training, 2018; Wright and Stucker, 2018).

Three surface mines in Fayette (2) and Somerset (1) Counties, Pennsylvania, produced 0.002 mst of Lower Bakerstown coal in 2017 (appendixes 11E and 11F); two other surface mines in Somerset County reported Lower Bakerstown coal as part of aggregate production of multiple beds, so we were unable to determine the exact amount of Lower Bakerstown coal produced in these mines (Pennsylvania Department of Environmental Protection, 2018). In 2016, 0.25 mst of Lower Bakerstown coal was produced from one surface mine in Garrett County, Maryland (Maryland Bureau of Mines, 2017) (appendix 13). No Lower Bakerstown coal was produced in Ohio or West Virginia in 2017 (West Virginia Office of Miners' Health, Safety and Training, 2018; Wright and Stucker, 2018).

One surface mine in Jefferson County, Pennsylvania, produced $0.015 \mathrm{mst}$ of Mahoning coal in 2017 (appendixes $11 \mathrm{E}$ and 11F); six other surface mines in Blair (1), Butler (1), Clearfield (3), and Indiana (1) Counties, Pennsylvania, reported Mahoning coal as part of aggregate production of multiple beds, so we were unable to determine the exact amount of Mahoning coal produced (Pennsylvania Department of Environmental Protection, 2018). No Mahoning coal was produced in Ohio or West Virginia in 2017, or Maryland in 2016 (Maryland Bureau of Mines, 2017; West Virginia Office of Miners' Health, Safety and Training, 2018; Wright and Stucker, 2018).

\section{Upper Freeport (E in Pennsylvania; No. 7 in Ohio) coal bed}

The Upper Freeport coal bed marks the top of the Middle Pennsylvanian Allegheny Group or Allegheny Formation. Ruppert and others (2001) describe Upper Freeport minable coal deposits occurring in irregularly shaped pods up to 15 miles long, separated by broad areas where the coal is thin to absent. They also note that within the pods there are locations where coal is thin to absent due to contemporaneous channels preventing peat accumulation or subsequent fluvial channel scouring or completely removing the peat. These pods appear to be "peat islands" or raised peat deposits separated by paleochannel complexes and interdistributary channels. Sulfur content is very low in the thick central part of at least one pod in northeastern Greene County, Pennsylvania, with increasing sulfur content in the thin edges adjacent to paleochannels (Shaffer, 1992; Brian Shaffer, U.S. Geological Survey, written commun., 2019). Consol Energy and Contura Coal hold large tracts of Upper Freeport coal where these pods exist in Greene, Washington, and Westmoreland Counties, Pennsylvania (Brian Shaffer, U.S. Geological Survey, written commun., 2019). The Upper Freeport is present over a large area of southwestern Pennsylvania, eastern Ohio, western Maryland, and northern to south-central West Virginia (Ruppert and others, 2001). The coal bed generally ranges from 1- to 12-ft thick, but most locations are less than 7-ft thick ("with high reject in West Virginia;" Mitch Blake, West Virginia Geological and Economic Survey, written commun., 2018). The coal bed is usually 3.5- to 7 -ft thick in Allegheny, Fayette, Washington, and Westmoreland Counties, Pennsylvania, and Belmont, Harrison, Guernsey, Jefferson, and Monroe Counties, Ohio (Ruppert and others, 2001) (fig. 10). In Allegheny County, Pennsylvania, and Tucker and Grant Counties, West Virginia (fig. 10), the Upper Freeport coal was often greater than 7-ft thick, but those occurrences have been mined-out (Ruppert and others, 2001). The Upper Freeport often exhibits multiple benches separated by thin shale partings. Luster gets duller near the top of the bed, and the upper part of the bed may consist of several inches of bone coal. Sulfur content and ash yield are highest near the base and top of the bed, and near the lateral margins of the pods (Ruppert and others, 2001). Coal quality also decreases adjacent to channels (Kertis, 1985; Ruppert and others, 2001). In southern Somerset County, Pennsylvania, the Upper Freeport ranges in thickness from 12 to 54 in., and commonly has two benches separated by a parting of 1 to 15 in. (Flint, 1965); the lower bench is usually less than 12-in. thick and composed of inferior-quality high-ash coal, while the upper bench is composed of fairly high-quality clean coal (low ash yield). Brian Shaffer of the U.S. Geological Survey (written commun., 2019) has noted that the parting in some locations in southern Somerset County was up to $10-\mathrm{ft}$ thick. The parting is usually a dark-gray argillaceous clay shale or friable claystone.

The Upper Freeport coal is low-volatile bituminous in rank in Allegany County, Maryland; low- to high-volatile bituminous in Cambria County, Pennsylvania; medium- to high-volatile bituminous in Clearfield, Fayette, Indiana, Somerset, and Westmoreland Counties, Pennsylvania, and Monongalia County, West Virginia; and high-volatile A bituminous in Allegheny, Armstrong, Clarion, Greene, Jefferson, and Washington Counties, Pennsylvania, and Brooke, Marion, Marshall, and Ohio Counties, West Virginia (Dowd and others, 1950a, b, 1951a, b, e, 1952a, 1955a, b, 1956; Wallace and others, 1953a, b, e, 1955a, b; Blaylock and others, 1955, 1956; Provost and others, 1956; Travis and others, 1956). It has medium to high ash yield (0 to 33.32 weight (wt.) percent; mean of $12.31 \pm 3.98)$ and sulfur content ( 0.38 to 5.85 wt. percent; mean of 2.24 \pm 1.02 ) on an as-received basis [ar] (Ruppert and others, 2001). In Cambria County, Pennsylvania, Dowd and others (1950b) note that sulfur in the Upper Freeport is difficult to wash out because the bed contains large amounts of bony coal and "miscellaneous near-gravity materials." White (1891) noted in Preston County, West Virginia (fig. 10), near the Cheat River, the Upper Freeport coal bed is low in sulfur content, has few partings, and makes good coking coals. Excellent exposures of the Upper Freeport can be seen in roadcuts along Interstate 68 east of the Cheat River to the Maryland State boundary with West Virginia (Brian Shaffer, U.S. Geological Survey, written commun., 2019). In the early 2000s, AMFIRE Mining Company (now owned by Rosebud Mining) supplied low-sulfur, low-volatile, bituminous coal 
from the Upper Freeport coal bed from a mine about 10 miles west of Ebensburg, Pennsylvania, in Cambria County, to a coke manufacturer in Pittsburgh, Pennsylvania, in the 1990s (Brian Shaffer, U.S. Geological Survey, written commun., 2019). Rosebud Mining is also planning to reopen a mine formerly owned by AMFIRE about 9 miles east of Ebensburg (Brian Shaffer, U.S. Geological Survey, written commun., 2019).

In the late 19th century, coke made from Upper Freeport coal at Bennington Station on Allegheny Mountain near Altoona, Pennsylvania, was reported to be of comparable quality to Connellsville coke (Historic American Engineering Record, 1994; see appendix 18). It was coked at several large coke plants along the Pennsylvania Railroad line on the summit of Allegheny Mountain in Cambria and Clearfield Counties (White, 1891). However, in the Ligonier coal basin of Westmoreland and Fayette Counties, the Upper Freeport was high in sulfur content and contained multiple partings, making it a poor coking coal (White, 1891). East of the town of Dunbar, Pennsylvania, in the Connellsville district, the Upper Freeport was mined extensively - and after cleaning was coked in a nearby by-product coke battery until the 1920s (Hickok and Moyer, 1940). Orton and others (1884) reported that slack (fine coal particles and dust) from the Upper Freeport was coked in Athens County, Ohio, making a "fairly firm coke," but its sulfur content was too high for foundry work. Stout and Lamborn (1924) report that the Upper Freeport coal can be coked, but due to high sulfur and ash, they recommended it for energy generation only.

In 2017, the Upper Freeport was the eighth most productive bed in the Appalachian basin coal region, and the 20th most productive bed in the United States (U.S. Energy Information Administration, 2018b) (appendix 9C). The Upper Freeport coal bed is mined for both thermal and metallurgical coal with total production of 4.994 mst of coal in 2017, $4.450 \mathrm{mst}$ coming from underground mines and $0.544 \mathrm{mst}$ coming from surface mines (appendix 9C). The minimum, maximum, and average thicknesses of produced coal in 2017 were 12, 91, and 62 in., respectively (appendix 9C).

Ten USBM county coking coal reports listed the Upper Freeport coal bed as an important coking coal in Allegany County, Maryland; Allegheny, Armstrong, Cambria, Fayette, Indiana, Somerset, Washington, and Westmoreland Counties, Pennsylvania; and Monongalia County, West Virginia (fig. 10) (Dowd and others, 1950a, b, 1951a, b, e; Wallace and others, 1953a, b, e, 1955b; Travis and others, 1956). The Upper Freeport was described as being of lesser importance in Clearfield and Jefferson Counties, Pennsylvania, and Marion County, West Virginia (Dowd and others, 1952a; Blaylock and others, 1955; Provost and others, 1956).

In 2017, 1.141 mst of coal from the Upper Freeport bed was produced from five underground mines in Armstrong (2), Cambria (2), and Indiana (1) Counties, Pennsylvania (appendixes 11C and 11D); one other underground mine in Indiana County reported the Upper Freeport as part of aggregate production of multiple beds, so we were unable to determine the exact amount of Upper Freeport coal produced in that mine (Pennsylvania Department of Environmental Protection, 2018). Five surface mines in Armstrong (2), Somerset (2), and Westmoreland (1) Counties, Pennsylvania, produced 0.184 mst of Upper Freeport coal in 2017 (appendixes 11E and 11F); 28 other surface mines in Cambria (1), Indiana (2), Clearfield (10), Elk (1), Fayette (1), Indiana (4), Jefferson (5), and Somerset (4) reported Upper Freeport as part of aggregate production of multiple beds, so we were unable to determine the exact amount of Upper Freeport coal produced in those mines (Pennsylvania Department of Environmental Protection, 2018).

In 2017, 0.252 mst of Upper Freeport (No. 7) coal was produced in Columbia, Harrison, Jefferson, Tuscarawas, and Vinton Counties, Ohio (Wright and Stucker, 2018) (appendix 12).

In 2016, 0.908 mst of Upper Freeport coal was produced from one underground mine in Garrett County, Maryland (Maryland Bureau of Mines, 2017) (appendix 13A). The Maryland Bureau of Mines report lists no mining of beds below the Upper Freeport in 2016.

In 2017, 2.099 mst of coal from the Upper Freeport bed was produced from one underground mine in Tucker County, West Virginia (West Virginia Office of Miners' Health, Safety and Training, 2018) (appendix 14). One surface mine in Logan County, West Virginia, produced 0.059 mst of Upper Freeport coal in 2017 (West Virginia Office of Miners' Health, Safety and Training, 2018) (appendix 14).

\section{Lower Freeport (D in Pennsylvania, No. 6A in Ohio) coal bed}

The Lower Freeport coal bed is located below the Upper Freeport coal bed in the middle Pennsylvanian Allegheny Group. In western Fayette County, Pennsylvania (fig. 10) the Lower Freeport coal bed ranges from 12- to 28-in. thick but can reach up to 96-in. thick in the southeast part of the county (Hickok and Moyer, 1940). In Fayette County, Pennsylvania, it is commonly a clean coal (without parting) but may have 2 to $3 \mathrm{in}$. of bone coal at the top and two to five partings in its lower half that range from 0.25- to 2-in. thick (Hickok and Moyer, 1940). In southern Somerset County, Pennsylvania, the Lower Freeport has a persistent thickness of about 3-ft, ranging from 2.5- to 4-ft thick (Flint, 1965).

The Lower Freeport coal is low- to medium-volatile bituminous in rank in Cambria and Somerset Counties, Pennsylvania, medium- to high-volatile A bituminous in Clearfield and Indiana Counties, Pennsylvania, and highvolatile A bituminous in Armstrong, Clarion, Jefferson, and Westmoreland Counties, Pennsylvania, and Ohio County, West Virginia (Dowd and others, 1950a, b, 1951a, e, 1952a, 1955b; Wallace and others, 1953a; Blaylock and others, 1955, 1956). In southern Clearfield County, Pennsylvania, medium-volatile bituminous Upper Freeport coal expands upon coking and can be improved by blending it with low-volatile bituminous coals (Blaylock and others, 1955). In Ohio County, West 
Virginia, the Lower Freeport coal has high ash yield and high sulfur content making it a poor choice for coke (Dowd and others, 1955b).

Details of the historical Lower Freeport coal mining in the central Pennsylvania can be found in appendix 19. Orton and others (1884) reported that in Steubenville, Ohio, the Lower Freeport makes a coke of fair strength and character despite having fairly high sulfur content. They considered it to be one of the best coking coals in Ohio, but it had difficulty competing in the market with coke from the Connellsville coke region of Pennsylvania. Orton and others (1884) reported the Lower Freeport as having strong coking properties in Coshocton County, Ohio, but high sulfur was also common there.

Nine USBM county coking coal reports described the Lower Freeport coal as an important coal bed in Cambria, Clearfield, Indiana, Jefferson, and Somerset Counties, Pennsylvania, and a bed of lesser to minor importance in Armstrong, Clarion, and Westmoreland Counties, Pennsylvania, and Ohio County, West Virginia (fig. 10) (Dowd and others, 1950a, b, 1951a, e, 1952a, and 1955b; Wallace and others, 1953a; Blaylock and others, 1955, 1956).

In 2017, $0.238 \mathrm{mst}$ of coal from the Lower Freeport bed was produced from one underground mine in Somerset County, Pennsylvania (Pennsylvania Department of Environmental Protection, 2018) (appendixes 11C and 11D). Six surface mines in Clearfield (1), Indiana (1), and Jefferson (4) Counties, Pennsylvania, produced 0.065 mst of Lower Freeport coal in 2017 (appendixes 11E and 11F); 32 other surface mines in Armstrong (1), Blair (1), Butler (1), Cambria (1), Centre (2), Clearfield (11), Indiana (4), Jefferson (5), Lycoming (1), and Somerset (5) Counties, Pennsylvania, reported Lower Freeport as part of aggregate production of multiple beds, so we were unable to determine the exact amount of Lower Freeport coal produced in those mines (Pennsylvania Department of Environmental Protection, 2018).

In 2016, 0.384 mst of Lower Freeport (No. 6a) coal was produced in Harrison, Stark, and Vinton Counties, Ohio (Wright and Stucker, 2018) (appendix 12).

No Lower Freeport coal was produced in West Virginia in 2017 (West Virginia Office of Miners' Health, Safety and Training, 2018).

\section{Upper Kittanning ( $C^{\prime}$ in Pennsylvania) coal bed}

The Upper Kittanning coal bed is located below the Lower Freeport coal bed in the middle Pennsylvanian Allegheny Group. In Ohio, the Upper Kittanning coal bed is not recognized as a mappable unit in the stratigraphic section. In Fayette County, Pennsylvania (fig. 10), the Upper Kittanning coal bed ranges from 12- to 108-in. thick and may have two or three benches separated by partings up to 6-in. thick (Hickok and Moyer, 1940). It is commonly a high-ash coal with 2 to 3 in. of bone coal at the top, and bone coal, shale, or pyrite near the base (Hickok and Moyer, 1940). The Upper Kittanning ranges from 0- to 177-in. thick in Cambria County (Iannacchione and Puglio, 1979), and 24- to 90-in. thick in Somerset County (Flint, 1965). In Beaver County, the Upper Kittanning is generally less than 6-in. thick except in an area in northwest Beaver County where there was 6 to 12 feet of cannel coal underlain by 6 to 12 in. of bituminous coal (Patterson, 1963); this thick coal deposit is now completely mined-out. In southern Somerset County, Pennsylvania, the Upper Kittanning ranges in thickness from 24 to 90 in., and commonly has two benches (Flint, 1965); the total thickness commonly ranges from 36 to 42 in., with $1 / 3$ to $1 / 2$ being high-quality low-ash coal. In northern Somerset County, where it has been extensively deep mined for thermal coal, the Upper Kittanning is laterally persistent ranging from 3to 5 -ft thick (Brian Shaffer, U.S. Geological Survey, written commun., 2019).

The Upper Kittanning coal is (1) low-volatile bituminous in rank in Somerset County, Pennsylvania, and Allegany County, Maryland; (2) low- to medium-volatile bituminous in Cambria County, Pennsylvania; (3) medium- to high-volatile bituminous in Clearfield and Indiana Counties, Pennsylvania; and (4) high-volatile A bituminous in Armstrong and Jefferson Counties, Pennsylvania, and Marion and Monongalia Counties, West Virginia (Dowd and others, 1950a, b, 1951a, 1952a; Wallace and others, 1953a, e; Blaylock and others, 1955; Provost and others, 1956; Travis and others, 1956). In Somerset County, Pennsylvania, the Upper Kittanning coal has high ash yield and high sulfur content, making cleaning necessary (Wallace and others, 1953a).

Nine USBM county coking coal reports described the Upper Kittanning coal as an important metallurgical coal bed in Allegany County, Maryland; Cambria, and Somerset Counties, Pennsylvania; and as a bed of lesser to minor importance in Armstrong, Clearfield, Indiana, and Jefferson Counties, Pennsylvania; and Marion and Monongalia Counties, West Virginia (fig. 10) (Dowd and others, 1950a, b, 1951a, 1952a; Wallace and others, 1953a, e; Blaylock and others, 1955; Provost and others, 1956; Travis and others, 1956).

In 2017, 1.164 mst of coal from the Upper Kittanning bed was produced from four underground mines in Clearfield (1), Indiana (1), and Somerset (2) Counties, Pennsylvania (appendixes 11C and 11D); one underground mine in Indiana County reported Upper Kittanning as part of aggregate production of multiple beds, so we were unable to determine the exact amount of Upper Kittanning coal produced in that mine (Pennsylvania Department of Environmental Protection, 2018). Two surface mines in Indiana (1) and Somerset (1) Counties, Pennsylvania, produced $0.067 \mathrm{mst}$ of Upper Kittanning coal in 2017 (appendixes 11E and 11F); 34 surface mines in Blair (1), Cambria (3), Centre (2), Clearfield (9), Fayette (1), Indiana (2), Jefferson (4), Lycoming (1), and Somerset (11) Counties, Pennsylvania, reported Upper Kittanning as part of aggregate production of multiple beds, so 
it is impossible to know the exact amount of Upper Kittanning coal produced in those mines (Pennsylvania Department of Environmental Protection, 2018).

No Upper Kittanning coal was produced in Ohio or West Virginia in 2017 (West Virginia Office of Miners' Health, Safety and Training, 2018; Wright and Stucker, 2018).

\section{Middle Kittanning ( $C$ in Pennsylvania, No. 6 in Ohio) coal bed}

The Middle Kittanning coal bed is located below the Upper Kittanning coal bed (in Ohio it is below the Lower Freeport because the Upper Kittanning is not recognized) in the middle Pennsylvanian Allegheny Group or Allegheny Formation. In Fayette County, Pennsylvania (fig. 10) the Middle Kittanning coal bed ranges from 0 - to 30 -in. thick and is composed of bony and dirty coal (Hickok and Moyer, 1940); it is considered unsuitable as a resource in Fayette County. In central Somerset County, Pennsylvania, Brian Shaffer of the U.S. Geological Survey (written commun., 2019) noted one location where the Middle Kittanning was $10-\mathrm{ft}$ thick containing numerous carbonaceous clay shale and impure coal partings. In Ohio, the Middle Kittanning coal bed usually has three benches separated by shale or clay partings (Bownocker and Dean, 1929), and is usually between 3- to 5- $\mathrm{ft}$ thick (Stout and Lamborn, 1924).

The Middle Kittanning coal is (1) low- and mediumvolatile bituminous in rank in Cambria and Somerset Counties, Pennsylvania; (2) low-, medium-, and high-volatile bituminous in Westmoreland County, Pennsylvania; (3) medium- to high-volatile bituminous in Clearfield and Indiana Counties, Pennsylvania; and (4) high-volatile A bituminous in Allegheny, Armstrong, Clarion, and Jefferson Counties, Pennsylvania (Dowd and others, 1950a, b, 1951a, e, 1952a; Wallace and others, 1953a, e; Blaylock and others, 1955, 1956). In Clearfield County, Pennsylvania, the high sulfur content of the Middle Kittanning makes it unsuitable for coking (Blaylock and others, 1955). Dowd and others (1951e) note in Westmoreland County, Pennsylvania, low-volatile bituminous Middle Kittanning coal expands during coking and should be blended with coals of lower rank to counteract the expansion. Orton and others (1884) reported the Middle Kittanning coal bed as making hard firm coke at Hammondsville, Jefferson County, Ohio, despite having high sulfur and ash. Stout and Lamborn (1924) reported that the Middle Kittanning had been coked extensively in Hammondsville, but it was barely being mined by the early 1920s. In Leetonia, Columbiana County, Ohio, the Middle Kittanning was coked extensively, making a hard, firm metallurgical grade coke used in local furnaces (Stout and Lamborn, 1924). Stout and Lamborn (1924) indicated that the Middle Kittanning was high in sulfur in most locations in eastern Ohio, but near Leetonia, its sulfur content is between 1 to 3 percent. They suggested that high-sulfur Middle Kittanning coal (not those near Leetonia) could be blended with low-volatile, bituminous, low-sulfur coal beds like the Pocahontas to make a satisfactory coke. A few early publications misidentified the major producing coal bed near Leetonia as the No. 4 (Newberry, 1878) or the No. 5 coal beds (Orton and others, 1884; Bownocker and others, 1908), but Stout and Lamborn (1924) correctly identified the major producing bed as the No. 6, which was confirmed by drilling and outcrop correlations performed by the Ohio Geological Survey in the 1980s (E. Slucher, U.S. Geological Survey, written commun., 2018).

Nine USBM county coking coal reports described the Middle Kittanning coal as a bed of lesser to minor importance in Allegheny, Armstrong, Cambria, Clarion, Clearfield, Indiana, Jefferson, Somerset, and Westmoreland Counties, Pennsylvania (fig. 10) (Dowd and others, 1950 a, b, 1951a, e, 1952a; Wallace and others, 1953a, b; Blaylock and others, 1955, 1956).

In 2017, 0.386 mst of coal from the Middle Kittanning bed was produced from two underground mines in Somerset County, Pennsylvania (Pennsylvania Department of Environmental Protection, 2018) (appendixes 11C and 11D). Two surface mines in Jefferson County, Pennsylvania, produced 0.030 mst of Middle Kittanning coal in 2017 (appendixes 11E and 11F); 30 other surface mines in Armstrong (1), Blair (1), Cambria (3), Centre (2), Clarion (1), Clearfield (11), Fayette (1), Jefferson (1), Lycoming (1), and Somerset (8) Counties, Pennsylvania, reported Middle Kittanning as part of aggregate production of multiple beds, so we were unable to determine the exact amount of Middle Kittanning coal produced in those mines (Pennsylvania Department of Environmental Protection, 2018). In 2017, 1.402 mst of Middle Kittanning coal was produced in Mahoning, Perry, Stark, Tuscarawas, and Vinton Counties, Ohio (Wright and Stucker, 2018) (appendix 12).

No Middle Kittanning coal was produced in West Virginia in 2017 (West Virginia Office of Miners' Health, Safety and Training, 2018).

\section{Lower Kittanning (B in Pennsylvania, No. 5 in Ohio) coal bed}

The Lower Kittanning coal bed is located below the Middle Kittanning coal bed in the middle Pennsylvanian Allegheny Group or Allegheny Formation. It is a single bed ranging from 1 - to 5 -ft thick in Pennsylvania that commonly consists of multiple benches separated by partings (Milici and others, 2001b), but in central Pennsylvania, the partings can increase in thickness to the point the bed splits into a zone containing up to five separate coal beds. In Barbour, Lewis, Preston, and Randolph Counties, West Virginia, the maximum total thickness can range between 7- to 12-ft thick (Milici and others, 2001b). In southern Somerset County, Pennsylvania, the Lower Kittanning ranges in thickness from 30 to 60 in., and commonly has two benches (Flint, 1965), an upper bench that is 30- to 32-in. thick, and a lower bench that is about 12-in. thick. 
The rank of the Lower Kittanning coal bed varies from low- and medium-volatile bituminous in Somerset, Cambria, Clearfield, Fayette, Armstrong, and Westmoreland Counties, Pennsylvania, to high-volatile $\mathrm{C}$ bituminous in southeast Ohio (Milici and others, 2001b). In Indiana County, Pennsylvania, the Lower Kittanning has VM ranging from 27 to 31 percent (Brian Shaffer, written commun., 2019). Milici and others (2001b) reported an overall mean sulfur content of $2.90 \mathrm{wt}$. percent (ar) (whole-coal basis) for 2,137 samples of the Lower Kittanning coal in Pennsylvania, Ohio, West Virginia, and Maryland. Sulfur contents ranged from 0.23 to 9.54 percent with an average of 2.90 percent and a standard deviation of 1.55 percent. They noted a general decrease in sulfur content from west to east. Ash yield for the same samples ranged from 2.20 to 32.55 percent with an average of 11.98 percent and a standard deviation of 4.69 percent.

White (1891) reported that Lower Kittanning coal was successfully coked in Tucker County, West Virginia (fig. 10), and was "nearly always a good coking coal everywhere" it was mined. Lower Kittanning coal was used for coking in local iron works near Leetonia in Columbiana County (fig. 10), Ohio (Orton and others, 1884; Bownocker and others, 1908; Stout and Lamborn, 1924).

In 2017, the Lower Kittanning was the fourth most productive coal bed in the Appalachian basin after the Pittsburgh, Blue Creek, and Pocahontas No. 3 coal beds (appendix 9C), and the 13th most productive coal bed in the United States (U.S. Energy Information Administration, 2018b). Production totaled 7.349 mst of thermal and coking coal, with 5.604 mst from underground mines and 1.744 mst from surface mines (appendix 9C). The minimum, maximum, and average bed thicknesses produced in 2017 were 10, 89, and 64 in., respectively (appendix 9C).

Six USBM county coking coal reports described the Lower Kittanning coal bed as an important coal bed in Armstrong, Cambria, Clarion, Clearfield, Indiana, and Somerset Counties, Pennsylvania, and as a bed of lesser to minor importance in Allegheny, Fayette, Jefferson, and Westmoreland Counties, Pennsylvania, and Marion and Monongalia Counties, Maryland (fig. 10) (Dowd and others, 1950a, b, 1951a, b, e, 1952a; Wallace and others, 1953a, b, c; Blaylock and others, 1955, 1956; Provost and others, 1956; Travis and others, 1956).

In 2017, 1.617 mst of coal from the Lower Kittanning bed was produced from ten underground mines in Armstrong (2), Clearfield (1), Indiana (5), Jefferson (1), and Somerset (1) Counties, Pennsylvania (Pennsylvania Department of Environmental Protection, 2018) (appendixes 11C and 11D). Seven surface mines in Clarion (2), Clearfield (1), Indiana (2), Jefferson (1), and Somerset (1) Counties, Pennsylvania, produced 0.179 mst of Lower Kittanning coal in 2017 (appendixes 11E and 11F); 26 other surface mines in Armstrong (1), Butler (1), Cambria (3), Centre (3), Clarion (1), Clearfield (8), Fayette (1), Lycoming (2), and Somerset (6) Counties, Pennsylvania, reported Lower Kittanning as part of aggregate production of multiple beds, so we were unable to determine the exact amount of Lower Kittanning coal produced in those mines (Pennsylvania Department of Environmental Protection, 2018).

In 2017, 0.73 mst of Lower Kittanning (No. 5) coal was produced in Jackson, Stark, Tuscarawas, and Vinton Counties, Ohio (Wright and Stucker, 2018) (appendix 12).

In 2017, 3.381 mst of Lower Kittanning coal was produced from one underground mine in Taylor County, West Virginia (West Virginia Office of Miners' Health, Safety and Training, 2018) (appendix 14). Nine surface mines in Boone (1), Fayette (3), Kanawha (2), Logan (1), Taylor (1), and Wayne (1) Counties, West Virginia, produced $1.466 \mathrm{mst}$ of Lower Kittanning coal in 2017 (West Virginia Office of Miners' Health, Safety and Training, 2018) (appendix 14).

Clarion ( $A^{\prime}$ in Pennsylvania, No. $4 A$ in Ohio) and Brookville ( $A$ in Pennsylvania, Newland or No. 4 in Ohio) coal beds/ zones

The Clarion coal bed is located below the Lower Kittanning coal bed in the Middle Pennsylvanian Allegheny Group. In Fayette County, Pennsylvania (fig. 10), the Clarion coal bed is separated from the underlying Brookville coal bed by a parting that ranges from a few inches up to $6 \mathrm{ft}$. For this reason, these two beds are sometimes considered as a single bed known as the Clarion-Brookville or the Brookville-Clarion coal bed (Hickok and Moyer, 1940). In Fayette County, the Brookville-Clarion coal zone ranges from 3-in. to 9-ft thick (Hickok and Moyer, 1940), with the top half being fairly clean coal (without parting), while the bottom half may be bony and high in ash. In southern Somerset County, Pennsylvania, the Brookville ranges in thickness from 60 to 132 in. (Flint, 1965; in the very thick locations about half of the bed is composed of non-coal material).

The Clarion coal bed (separated into Upper Clarion and Lower Clarion beds and not including the Brookville coal) was described as an important coal bed in Clarion County, Pennsylvania (Blaylock and others, 1956). In Armstrong, Cambria, Indiana, and Somerset Counties, Pennsylvania (fig. 10), the Clarion coal bed was described as a bed of lesser to minor importance (Dowd and others, 1950a, b, 1951a; Wallace and others, 1953a). In Fayette County, Pennsylvania, the USBM report notes the Brookville-Clarion coal zone is of lesser to minor importance (Dowd and others, 1951b). The Brookville coal bed is described as a bed of lesser to minor importance in Cambria, Clarion, Clearfield, Indiana, and Jefferson Counties, Pennsylvania (Dowd and others, 1950a, b, 1952a; Blaylock and others, 1955, 1956).

Two surface mines in Clarion County, Pennsylvania, produced 0.44 mst of Clarion coal in 2017 (appendixes 11E and $11 \mathrm{~F}$ ); seven other surface mines in Armstrong (1), Butler (1), Centre (2), and Clearfield (3) Counties, Pennsylvania, reported Clarion as part of aggregate production of multiple beds, so we were unable to determine the exact amount of Clarion coal produced in those mines (Pennsylvania Department of Environmental Protection, 2018). 
In 2017, 0.15 mst of Clarion (No. 4a) coal was produced in Vinton County, Ohio, (Wright and Stucker, 2018) (appendix 12).

In 2017, 2.863 mst of Clarion coal was produced from one underground mine in Barbour County, West Virginia (West Virginia Office of Miners' Health, Safety and Training, 2018) (appendix 14). Three surface mines in Kanawha (1) and Logan (2) Counties, West Virginia, produced $1.728 \mathrm{mst}$ of Clarion coal in 2017 (West Virginia Office of Miners' Health, Safety and Training, 2018) (appendix 14).

\section{Pottsville Coking Coals}

White (1891) described the coals of the Pennsylvanian Pottsville Group of West Virginia south to Alabama (where it is called the Pottsville Formation) as "always cementing (agglutinating), and making good coke," and Pottsville coals of Ohio and western Pennsylvania as "open-burning," "hard," and "non-cementing" (non-agglutinating) coals that "can be used in furnaces in the raw state." He also reported that Pottsville coals are low in ash yield and sulfur content throughout the Appalachian basin.

Hickok and Moyer (1940) named only one Pottsville bed of mineable thickness in Fayette County, Pennsylvania, the Mercer coal bed. It reaches a maximum thickness of $55 \mathrm{in}$., but in many places, it was much thinner and (or) contained numerous partings which made it unusable for coking due to high ash yield and sulfur content.

One surface mine in Jefferson County, Pennsylvania, produced 0.002 mst of Mercer coal in 2017 (appendixes 11E and 11F); another surface mine in Centre County reported Mercer as part of aggregate production of multiple beds, so it is not possible to determine the amount of Mercer coal produced in that mine (Pennsylvania Department of Environmental Protection, 2018).

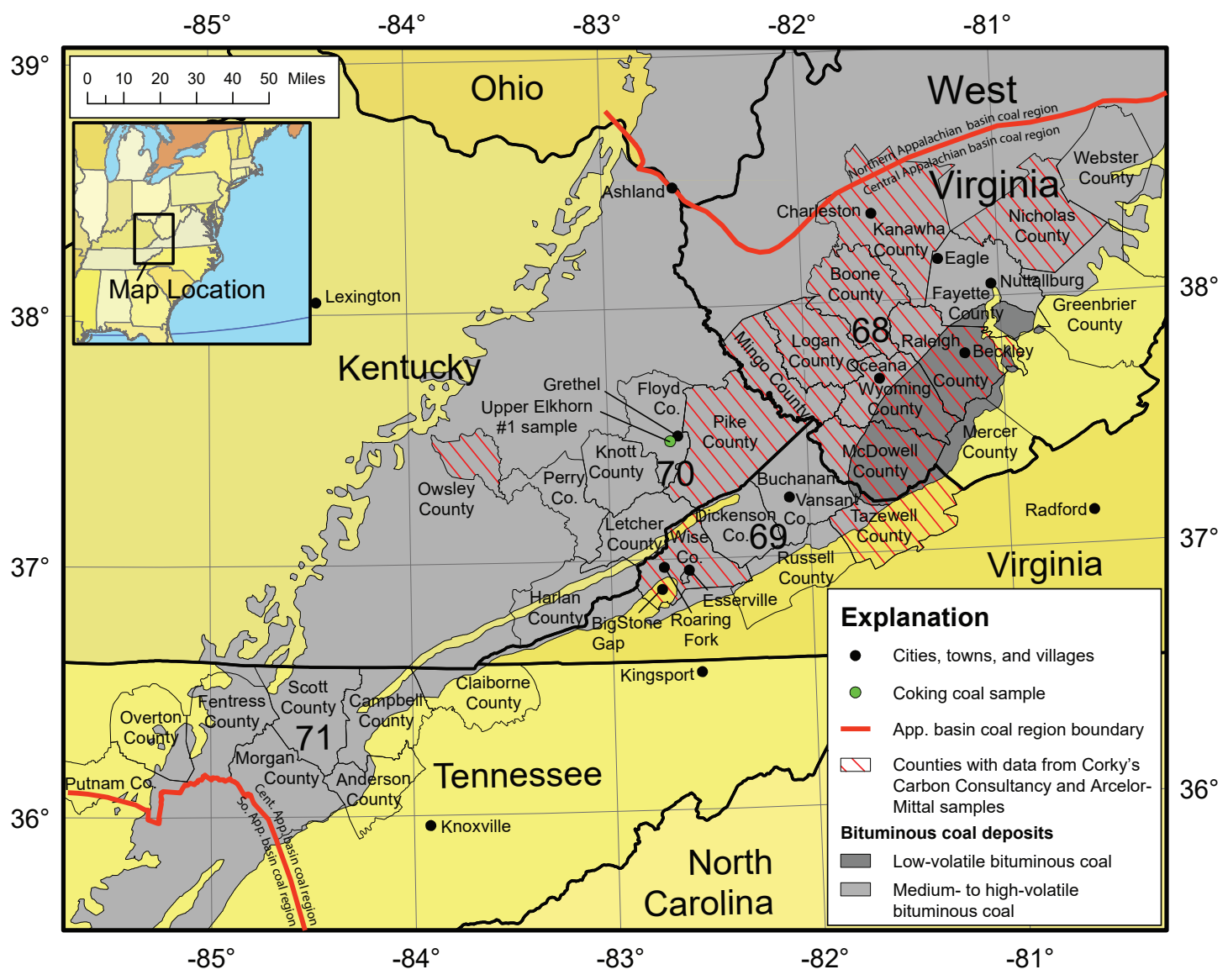

Figure 11. Map showing the locations of bituminous coal deposits in the States of West Virginia, Virginia, eastern Kentucky, and Tennessee in the central Appalachian basin coal region. Numbers 68 to 71 correspond to coking coal deposit locations identified in the text and appendix 1. The green-filled circle is the location of the coking coal sample from Floyd County, Kentucky, discussed in the text; sample analysis results are provided in appendixes 2 to 8 (tables 2.1 to 8.1). These data can also be downloaded from https://doi.org/10.5066/P9KF0OKM. The red diagonal lines (striped pattern) indicate counties with coking coal data in appendixes 2 to 8 (tables 2.1 to 8.1). Abbreviations: App., Appalachian; Cent., Central; Co., County; Med., medium; So., Southern. 
No Mercer coal was produced in Ohio or West Virginia in 2017 (West Virginia Office of Miners' Health, Safety and Training, 2018; Wright and Stucker, 2018).

\section{Coking Coals in the Central Appalachian Basin Coal Region}

The Central Appalachian basin coal region (per Trippi and others, 2014a) includes parts of the States of West Virginia, Kentucky, Virginia, and Tennessee (locations 68 through 71 on fig. 11). Formation and coal bed names vary from State to State, adding a bit of confusion to the discussion about equivalent beds on opposite sides of State lines. Therefore, the stratigraphy and nomenclature used for each State will be discussed separately in the next section. Correlations between named coal beds and coal zones within one State and another State within the Central Appalachian basin coal region can be found in Ruppert and others (2014).

The U.S. Energy Information Administration (2018b) reported a total of 9.469 mst of Pocahontas No. 3 coal produced from underground mines in the Central Appalachian basin (in Virginia, West Virginia, and Kentucky) in 2017 (appendix 9C). The Pocahontas No. 3 was the tenth most productive coal bed in the U.S., and the third most productive coal bed in the Appalachian basin (after the Pittsburgh and Blue Creek beds) in 2017 (appendix 9C). Mined thicknesses ranged from 35 to 71 in., with an average of $60 \mathrm{in}$. (appendix 9C).

The U.S. Energy Information Administration (2018b) reported production of $6.477 \mathrm{mst}$ of Eagle coal $(5.547 \mathrm{mst}$ underground, $0.930 \mathrm{mst}$ surface) in the Central Appalachian basin (in Virginia, West Virginia, and Kentucky) in 2017, making it the 14th most productive bed in the United States and the fifth most productive bed in the Appalachian basin (appendix 9C). The mined thickness of the Eagle ranged from 4 to 114 in., with an average of 43 in. (appendix 9C).

The U.S. Energy Information Administration (2018b) reported production of $5.780 \mathrm{mst}$ of Lower Elkhorn coal (4.378 mst underground, $1.402 \mathrm{mst}$ surface) in the Central Appalachian basin (in Virginia, West Virginia, and Kentucky) in 2017, making it the 17th most productive bed in the United States and the sixth most productive bed in the Appalachian basin (appendix 9C). The mined thickness of the Lower Elkhorn ranged from 10 to 60 in., with an average of 43 in. (appendix 9C).

The U.S. Energy Information Administration (2018b) reported production of $5.467 \mathrm{mst}$ of Coalburg coal ( $0.439 \mathrm{mst}$ underground, $5.028 \mathrm{mst}$ surface) in the Central Appalachian basin (in Virginia, West Virginia, and Kentucky) in 2017, making it the 19th most productive bed in the United States and the seventh most productive bed in the Appalachian basin (appendix 9C). The mined thickness of the Coalburg ranged from 12 to $126 \mathrm{in}$., with an average of $81 \mathrm{in}$. (appendix 9C).
The U.S. Energy Information Administration (2018b) reported production of $4.735 \mathrm{mst}$ of Stockton-Lewiston coal (2.341 mst underground, $2.394 \mathrm{mst}$ surface) in the Central Appalachian basin (in Virginia, West Virginia, and Kentucky) in 2017, making it the 22nd most productive bed in the United States and the ninth most productive bed in the Appalachian basin (appendix 9C). The mined thickness of the StocktonLewiston ranged from 10 to 105 in., with an average of 69 in. (appendix 9C).

The U.S. Energy Information Administration (2018b) reported production of 4.544 mst of Upper Elkhorn No. 3 coal (3.088 mst underground, $1.456 \mathrm{mst}$ surface) in the Central Appalachian basin (in Virginia, West Virginia, and Kentucky) in 2017, making it the 23rd most productive bed in the United States and the tenth most productive bed in the Appalachian basin (appendix 9C). The mined thickness of the Upper Elkhorn No. 3 ranged from 12 to 115 in., with an average of 45 in. (appendix 9C).

\section{Coking Coals in Southern West Virginia}

In southern West Virginia (location 68 on figs. 2 and 11), there are several dozen coal beds in the Lower to Middle Pennsylvanian strata in four different formations (listed in ascending order): (1) the Lower Pennsylvanian Pocahontas Formation, (2) the Lower Pennsylvanian New River Formation, (3) the Lower to Middle Pennsylvanian Kanawha Formation, and (4) the Middle Pennsylvanian Allegheny Formation.

The Pocahontas Formation includes six Pocahontas coal beds that are known to have coking properties. They are named Pocahontas No. 2 through Pocahontas No. 7 (in ascending order). The Pocahontas No. 3 coal is the most productive of the group (Milici and others, 2001a). In 2018, the West Virginia Geological and Economic Survey listed 12 coal beds in the Pocahontas Formation on their website at http://www.wvgs.wvnet.edu/www/coal/cbmp/poc_col.html.

The New River Formation includes 11 coal beds that are known to have coking properties. They are named Pocahontas No. 8, Pocahontas No. 9, Little Fire Creek, Fire Creek, Beckley, Little Raleigh, Welch, Sewell, Sewell B, Castle, Iaeger, and Bradshaw (in ascending order). In 2018, the West Virginia Geological and Economic Survey listed 19 coal beds in the New River Formation on their website at http://www.wvgs.wvnet.edu/www/coal/cbmp/nrv_col.html (maps of New River Formation coal beds).

Hennen and Reger (1914) published a stratigraphic framework of the Kanawha Formation (including more than a dozen coal beds) in Logan and Mingo Counties, West Virginia. That same year Krebs and Teets (1914) published a stratigraphic framework of the Kanawha Formation 70 miles to the northeast in Kanawha County, West Virginia. Unfortunately, the two stratigraphic frameworks did not agree at several horizons, creating difficulties in correlation of coal beds and 
other units between these two areas. Blake $(1992,1998)$ and Blake and others (1994) published a revised stratigraphic framework of the Kanawha Formation to clear up the confusion, but there is still uncertainty when dealing with publications prior to this revised stratigraphic framework. This uncertainty includes 26 of the 31 coal beds in the Kanawha Formation listed in USBM county coking coal reports from the 1950s for Logan, McDowell, Mercer, Mingo, Raleigh, and Wyoming Counties, West Virginia (Dowd and others, 1952c; Wallace and others, 1952, 1953c, and 1954a, b; Tavenner and others, 1956). This issue is discussed further below. In 2018, the West Virginia Geological and Economic Survey (WVGES) listed 43 coal beds in the Kanawha Formation on their website (http://www.wvgs.wvnet.edu/www/coal/cbmp/kan_col.html) including (in descending order) the Upper Mercer, Stockton Rider, Stockton, Stockton Lower Split, Coalburg, Coalburg Lower Split, Little Coalburg, Upper Winifrede, Winifrede, Lower Winifrede, Chilton A, Chilton Rider, Chilton, Little Chilton, Fire Clay Rider, Fire Clay, Fire Clay Lower Split, Little Fire Clay, Cedar Grove, Williamson Rider, Williamson, Peerless, No. 2 Gas, No. 2 Gas Lower Split, Powellton A, Powellton, Lower Powellton, Eagle A, Eagle, Eagle Lower Split, Little Eagle, Cedar, Middle War Eagle, Ben's Creek, Little Middle War Eagle, Lower War Eagle, Glenalum Tunnel, Gilbert A, Gilbert, Douglas A, Douglas, Aily, and the Lower Douglas coal beds.

Only three coal beds are commonly found in the Middle Pennsylvanian Allegheny Formation in southern West Virginia: the No. 5 Block, the Upper No. 5 Block, and the No. 6 Block coal beds (in ascending order). The Upper No. 5 Block and the No. 6 Block may be equivalent to the Upper Mercer and Clarion coal beds, respectively, of the Northern Appalachian basin coal region (Cortland Eble, Kentucky Geological Survey, written commun., 2018).

A series of six county coking coal reports by the USBM in the 1950s (Dowd and others, 1952c; Wallace and others, 1952, 1953c, 1954a, b; Tavenner and others, 1956) identified 48 coal beds that have coking properties in the southwestern West Virginia part of the Central Appalachian basin coal region, including (in descending stratigraphic order): the Upper No. 5 Block and No. 5 Block coal beds of the Middle Pennsylvanian Allegheny Formation; the Stockton-Lewiston, Coalburg, Little Coalburg, Buffalo Creek (Upper Winifrede), Winifrede, Lower Winifrede, Chilton A, Chilton, Little Chilton, Upper Hernshaw, Hernshaw (or Middle Hernshaw), Lower Hernshaw, Williamson, Upper Cedar Grove, Upper split of the Cedar Grove, Cedar Grove, Lower Cedar Grove, Alma A, Alma, Peerless (or upper Campbell Creek), No. 2 Gas (or lower Campbell Creek), Upper Powellton, Powellton, Upper Eagle, Eagle, Ben's Creek, Little Eagle, Lower War Eagle, Gilbert, Douglas, and Lower Douglas coal beds of the Lower to Middle Pennsylvanian Kanawha Formation; the Iaeger, Sewell B, Sewell, Welch, Little Raleigh, Beckley, Fire Creek, Little Fire Creek, and Pocahontas No. 9 coal beds of the Lower Pennsylvanian New River Formation; and the Pocahontas No. 7, Pocahontas No. 6, Pocahontas No. 5, Pocahontas No. 4, Pocahontas No. 3, and Pocahontas No. 2 coal beds of the Lower Pennsylvanian Pocahontas Formation. Mitch Blake of the West Virginia Geological and Economic Survey (written commun., 2018) pointed out several possible errors with the coal beds named in these USBM reports, including: (1) early reports locally named the Winifrede coal bed as the Coalburg; (2) the Chilton A bed in the USBM reports is probably a split of the Lower Winifrede; (3) the Chilton bed in USBM reports may have been named correctly in some locations, but may actually be the Fire Clay in other locations; (4) the Hernshaw coal in the USBM reports is actually the Cedar Grove, and the Upper Hernshaw and Lower Hernshaw are actually the Upper and Lower Cedar Grove beds, respectively; (5) the Alma and Alma A of the USBM reports are actually the Upper Powellton and Powelltown coals, respectively; (6) the Upper Eagle in the USBM reports is actually the Middle War Eagle; (7) the Ben's Creek bed in the USBM reports (shown between the Eagle and Little Eagle) is misidentified because the actual location for the Ben's Creek bed is between the Middle and Lower War Eagle); and (8) the Lower Douglas bed in the USBM reports is probably the Bradshaw bed of the New River Formation (the Lower Douglas is not mined in West Virginia).

Lotz (1970) published probable original minable extent maps of 64 coal beds in the Dunkard Group, Monongahela Group, Conemaugh Group, Allegheny Formation, Kanawha Formation, New River Formation, and Pocahontas Formation in West Virginia. Unfortunately, the same uncertainty issues for beds below the Winifrede and above the Lower Douglas probably exist for these maps.

Barlow (1974) published a series of maps of original minable extent, coal rank and fixed carbon, sulfur content, and ash content for all West Virginia coals. A similar series of maps of ash yield, Btu heating value, coal rank, and sulfur content was published by the West Virginia Geological and Economic Survey in 1980 (West Virginia Geological and Economic Survey, 1980a, b, c, d), and a third map series showing total sulfur content in the Beckley, Coalburg, Lower Kittanning (No. 5 Block), Pittsburgh, Pocahontas No. 3, and Sewell beds was published in 1983 (Smith and King, 1982).

Repine and others (1993) reported that the Pocahontas No. 3 bed was responsible for about four percent of West Virginia's total coal production in 1993. They described the Pocahontas No. 3 as a low-volatile, high-quality metallurgicalgrade coal, with a median total-sulfur content of less than 0.6 percent, median ash yield of less than five percent, and median heating value greater than $14,600 \mathrm{Btu} / \mathrm{lb}$. They estimated that from its original resources (greater than three billion tons) in West Virginia, only about 900 mst of it remained in 1993, with about one-quarter of that amount under greater 
than $1000 \mathrm{ft}$ of overburden. Pocahontas No. 4 and No. 6 have total sulfur content, ash yield, and heating values similar to the Pocahontas No. 3.

The Fire Creek, Beckley, and Sewell coal beds of the New River Formation are low- to medium-volatile bituminous coals with median total-sulfur contents of 0.7 percent, median ash yields of 5.5 percent, and median heating values of $14,500 \mathrm{Btu} / \mathrm{lb}$ (Repine and others, 1993). The Sewell bed is a low- to medium-volatile metallurgical-grade coal that averages about 4- to 5-ft thick, ranging up to $22 \mathrm{ft}$ in some locations.

The Kanawha Formation includes high-quality highvolatile A bituminous coals that are acceptable for both steam and metallurgical use (Repine and others, 1993). In 1988 , these coal beds made up 43 percent of the coal produced in West Virginia. Repine and others (1993) reported that Kanawha coals had a median total-sulfur content of 0.8 percent, median ash yield of 5.5 percent, and median heating value of $14,000 \mathrm{Btu} / \mathrm{lb}$. The No. 2 Gas and Peerless beds together accounted for nine percent of the total production of West Virginia coal in 1988. The Winifrede coal bed is a clean, pure, high-quality coal, with few partings and excellent metallurgical properties, but extensive mining had brought it close to depletion in 1993. Repine and others (1993) did not consider the Coalburg bed to be suitable for metallurgical purposes.

The Allegheny Formation contains high-volatile A to medium-volatile bituminous coals with a median total-sulfur content of 1.1 percent, median ash yield of 8.0 percent, and median heating value of 13,500 Btu/lb. The No. 5 Block bed was the second highest producer in West Virginia after the Pittsburgh coal bed in 1993.

In late 2016, Alpha Natural Resources estimated they had approximately $247 \mathrm{mst}$ of metallurgical coal reserves in Fayette, Logan, Kanawha, Raleigh, and Wyoming Counties, West Virginia, where they mine Alma, Coalburg, Cedar Grove, Douglas, Eagle, Glen Alum, Hernshaw, Pocahontas No. 3, Powellton, Sewell, and Stockton coals (Alpha Natural Resources, 2016).

After reaching a peak of $158 \mathrm{mst}$ in 2008 (for both steam and coking coal), West Virginia coal production declined in the past decade to a low value of only $80 \mathrm{mst}$ in 2016 (Lego and Deskins, 2017). An upturn in metallurgical coal prices during the first half of 2015 resulted in a rebound in coal production, but the total remained below early 2015 levels. Production in southern West Virginia dropped from about two-thirds of the total for the State in 2011 to only 46 percent in 2016. Nationally, the long-term decline of the steel industry has resulted in the decline of domestic coking coal used between 1990 and 2016 from nearly 39 mst to less than 17 mst (Lego and Deskins, 2017). In West Virginia, domestic metallurgical coal use declined 39 percent since 2011 to only 8.3 mst in 2016 (Lego and Deskins, 2017).

A spike in West Virginia coking coal exports occurred in 2011 and 2012 when flooding in Australia temporarily shut down mines in Queensland, causing a disruption in coking coal supplies to Asia-Pacific nations like India, China, Japan, and South Korea. The subsequent rise in metallurgical coal prices made southern West Virginia metallurgical coal competitive, resulting in a temporary increase of exports to those nations. However, a return to normal production levels in the Queensland mines in 2013 and 2014 caused prices to drop again, and southern West Virginia coal was no longer competitive with Australian coal (Lego and Deskins, 2017).

In the fourth quarter of 2016, after a drastic cut back of China steel production, the global demand for steel rose, also driving up the price of coking coal to about $\$ 118$ per short ton, and southern West Virginia coal exports rose. Then in March of 2017, cyclone damage to railroads in Queensland once again halted much of Australia's coal production, further boosting the price of coking coal and exports of coking coal from southern West Virginia in late 2017 (Lego and Deskins, 2017).

Lego and Deskins (2017) expect that southern West Virginia coking coal will become more expensive to produce as reserves become increasingly depleted in coming decades, thus making these coals less competitive on the global market than Australian and Indonesian coals. Adoption of steel recycling and electrolysis in the future may also reduce the demand for coking coal (Lego and Deskins, 2017). As a result of these and other changes, total coal production in West Virginia may drop to 70 mst by 2040 (Lego and Deskins, 2017).

The U.S. Energy Information Administration (2018b) reported a total of 125 mines in 12 counties in southern West Virginia that produced $46.037 \mathrm{mst}$ of thermal and metallurgical coal in 2017 (25.944 mst from 55 underground mines, $20.092 \mathrm{mst}$ from 70 surface mines) (appendix 9A). The largest producers were Logan, Kanawha, Raleigh, Mingo, Wyoming, and Boone Counties with $9.884 \mathrm{mst}, 6.258 \mathrm{mst}$, $6.146 \mathrm{mst}, 5.353 \mathrm{mst}, 4.987 \mathrm{mst}$, and $4.984 \mathrm{mst}$, respectively (appendix 9A). They also reported that $21.474 \mathrm{mst}$ was metallurgical coal and 18.577 was non-metallurgical coal (appendix 9B). The West Virginia Office of Miners' Health, Safety and Training (2018) did not categorize their data based on northern and southern regions, so it is unclear in several counties that straddle the boundary between the two regions which data belong to which region. We were therefore unable to report the total production in southern West Virginia using their report.

As already described in the introduction to the Central Appalachian basin section above, the U.S. Energy Information Administration (2018a) reported production amounts and bed thicknesses of the Pocahontas, Eagle, Lower Elkhorn, Coalburg, Stockton-Lewiston, and Upper Elkhorn No. 3 coals in the Central Appalachian basin (in West Virginia, Virginia, and Kentucky) in 2017 (U.S. Energy Information Administration, 2018a) (appendix 9C). Go to the introductory section for the Central Appalachian basin above and appendix $9 \mathrm{C}$ for more information.

The West Virginia Office of Miners' Health, Safety and Training (2018) reported a total of $41.918 \mathrm{mst}$ of coal produced from 70 surface mines $(16.256 \mathrm{mst})$ and 58 underground mines ( $25.662 \mathrm{mst}$ ) from 33 coal beds in the Kanawha, New 
River, and Pocahontas Formations in southern West Virginia in 2017 (appendix 14). Note that State agency production totals usually do not exactly match U.S. Energy Information Administration totals. Five coal beds, the Stockton-Lewiston, Eagle, Coalburg, Pocahontas No. 3, and the Alma, produced a total of 24,200 mst, about 58 percent of the total produced by all 33 beds in West Virginia. The remaining 28 beds produced a total of 17.718 mst. Five counties, Logan, Raleigh, Kanawha, Wyoming, and Mingo produced 9.914, 7.003, $4.757,4.453$, and $4.074 \mathrm{mst}$ of coal, respectively, from beds in the Kanawha, New River, and Pocahontas Formations in West Virginia (West Virginia Office of Miners' Health, Safety and Training, 2018) (appendix 14).

In 2017, 3.844 mst of Stockton-Lewiston coal was produced from five surface mines in Fayette (2), Lincoln (1), Logan (1), and Raleigh (1) Counties, West Virginia; 2.341 mst was produced from three underground mines in Kanawha County (West Virginia Office of Miners' Health, Safety and Training, 2018) (appendix 14).

A total of $0.086 \mathrm{mst}$ of Eagle coal was produced from one surface mine in Wyoming County, West Virginia, in 2017; 5.830 mst was produced from ten underground mines in Boone (2), Fayette (1), Kanawha (1), Logan (1), Nicholas (1), Raleigh (3), and Wyoming (1) Counties in 2017 (West Virginia Office of Miners' Health, Safety and Training, 2018) (appendix 14).

There were 4.884 mst of Coalburg coal produced from fourteen surface mines in Boone (4), Fayette (2), Logan (4), Mingo (3), and Raleigh (1) Counties, West Virginia, in 2017; $0.332 \mathrm{mst}$ was produced from one underground mine in Mingo County in 2017 (West Virginia Office of Miners' Health, Safety and Training, 2018) (appendix 14).

A total of $0.138 \mathrm{mst}$ of Pocahontas No. 3 coal was produced from one surface mine in Mercer County, West Virginia, in 2017; $4.113 \mathrm{mst}$ was produced from six underground mines in McDowell (2), Raleigh (2), and Wyoming (2) Counties in 2017 (West Virginia Office of Miners' Health, Safety and Training, 2018) (appendix 14).

In 2017, 0.040 mst of Alma coal was produced from one surface mine in Logan County, West Virginia; 2.591 mst was produced from four underground mines in Logan County (West Virginia Office of Miners' Health, Safety and Training, 2018) (appendix 14).

Analytical data from forty samples of coking coal from a mine in McDowell County, West Virginia, were shared with the USGS by Richard Kruse of ArcelorMittal USA. The results of the analyses of these forty samples are listed in appendixes 2 to 8 and discussed in the "Sample Data From Other Sources" and "Discussion of Results" sections of this report. The location of McDowell County is shown on figure 11. These data can also be downloaded from https://doi.org/10.5066/P9KFQOKM.

Analytical data from fifteen samples of coking coal from southern West Virginia were shared with the USGS by David Cork of the Corky's Carbon Consultancy. Four samples came from mines in Boone County, three each came from mines in Logan and Raleigh Counties, two came from Nicholas County, and one each came from Kanawha, Mingo, and Wyoming Counties. The results of the analyses of these fifteen samples are listed in appendixes 2 to 8 and discussed in the "Sample Data From Other Sources" and "Discussion of Results" sections of this report. Locations of these counties are shown on fig. 11. These data can also be downloaded from https://doi.org/10.5066/P9KFQOKM.

\section{Coking Coals in Southwestern Virginia}

Southwestern Virginia (location 69 on figs. 2 and 11) has several dozen coal beds in the Lower to Middle Pennsylvanian in three different formations (listed in ascending order): (1) the Lower Pennsylvanian Lee Formation, (2) the Lower Pennsylvanian Norton Formation, and (3) the Lower to Middle Pennsylvanian Wise Formation.

A series of five USBM county coking coal reports in the 1950s and 1960s identified 42 coal beds with coking properties in southwestern Virginia, including (in descending stratigraphic order): the High Splint, Morris, Pardee, Phillips, Low Splint, Cedar Grove, Taggart (or Lower Cedar Grove), Taggart Marker, Upper Standiford (or Wilson), Kelly, Imboden (or Campbell Creek), Addington, Clintwood, Eagle, Blair, Lyons, and Dorchester coal beds of the Lower to Middle Pennsylvanian Wise Formation; the Norton, Hagy, Splash Dam, Upper Banner, Lower Banner, Big Fork (or Caldwell), Kennedy, Aily, Raven, Jawbone, and Tiller coal beds of the Lower Pennsylvanian Norton Formation; and the Upper Seaboard, Greasy Creek, Middle Seaboard, Lower Seaboard, Upper Horsepen, Middle Horsepen, C, War Creek, Lower Horsepen, Pocahontas No. 7, Pocahontas No. 6, Pocahontas No. 5, Pocahontas No. 4, and Pocahontas No. 3 (or Burton's Ford) coal beds of the Lower Pennsylvanian Lee Formation (Gray and Boley, 1958a, b; Deurbrouck, 1963a, b, 1966).

Sweet (1969) reported that only Buchanan and Wise Counties, Virginia, had active coke operations in 1969. Coal from the Taggart and Lyons beds was being coked in beehive ovens near Esserville in Wise County by the Christie Coal and Coke Company, Inc. The Jewell Smokeless Coal Corporation coked coal from the Kennedy, Raven, Splash Dam, and Jawbone coal beds near Vansant in Buchanan County in 1969; as of 2019, it is still operating (John Popp, written commun., 2019). The Westmoreland Coal Company operated a coke plant 15 miles northeast of Big Stone Gap, near Roaring Fork in Wise County, which used Taggart bed coal. There were 309,246 short tons of coal coked in 772 ovens in Virginia in 1966 (Sweet, 1969).

Virginia produced $17 \mathrm{mst}$ of thermal and coking coal in 2013, down from a peak of $46.6 \mathrm{mst}$ in 1990 (Virginia Department of Mines, Minerals, and Energy, 2014). Locations of active and abandoned mines in southwest Virginia are displayed, and GIS files of these locations can be downloaded, from the interactive mapping webpage of the Virginia Department of Mines, Minerals, and Energy at https://www.dmme.virginia.gov/webmaps/DM/. As of 
Coking Coal of the United States-Modern and Historical Coking Coal Mining Locations and Other Data from Samples

October 26, 2017, they showed active mines for the following coal beds in southwest Virginia: Pardee (one mine in Lee County), Phillips (one mine in Lee County), Low Splint (two mines in Wise County, one mine in Lee County), 34-Inch (or Cedar Grove) (one mine in Wise County), Wilson (one mine in Lee County, one mine in Wise County), Imboden (three mines in Wise County, one mine in Buchanan), Blair (one mine in Buchanan County), Norton (one mine in Dickenson and Wise Counties), Hagy (five mines in Buchanan County), Splash Dam (six mines in Buchanan County), Upper Banner (two mines in Dickenson County), Lower Banner (four mines in Dickenson County), Kennedy (one mine in Buchanan County), Raven (three mines in Buchanan, one mine in Russell County), Jawbone (three mines in Buchanan County, one mine in Dickenson County), Tiller (one mine in Buchanan, one mine in Russell and Tazewell Counties), War Creek (one mine in Tazewell County), and Pocahontas No. 3 (four mines in Buchanan County).

The U.S. Energy Information Administration (2018a) reported $13.202 \mathrm{mst}$ of thermal and (or) coking coal produced from 52 mines in five counties in southwestern Virginia in 2017 (9.820 mst from 25 underground mines, and $3.382 \mathrm{mst}$ from 27 surface mines) (appendix 9A). The largest producers were Buchanan, Dickenson, and Wise Counties with $7.931 \mathrm{mst}, 3.358 \mathrm{mst}$, and $1.507 \mathrm{mst}$, respectively (appendix 9A). They also reported $11.532 \mathrm{mst}$ was metallurgical coal and 1.404 mst was non-metallurgical (appendix 9B).

As already described in the introduction to the Central Appalachian basin section above, the U.S. Energy Information Administration (2018a) reported production amounts and bed thicknesses of the Pocahontas No. 3, Eagle, Lower Elkhorn, Coalburg, Stockton-Lewiston, and Upper Elkhorn No. 3 coals in the Central Appalachian basin (in West Virginia, Virginia, and Kentucky) in 2017 (U.S. Energy Information Administration, 2018a) (appendix 9C). Go to the introductory section for the Central Appalachian basin above and appendix 9C for more information.

The Virginia Department of Mines, Minerals, and Energy Division of Geology and Mineral Resources reports that coal production in Virginia peaked at $46.6 \mathrm{mst}$ in 1990, with a subsequent drop to a low of only $12.2 \mathrm{mst}$ in 2016 , followed by a slight increase to $12.8 \mathrm{mst}$ in 2017 . The estimated market value of coal produced in Virginia peaked at $\$ 3.02$ billion in 2011 , followed by a precipitous drop in the next four years to $\$ 746$ million in 2016. In 2017, the estimated market value rose slightly to $\$ 781$ million (Virginia Department of Mines, Minerals, and Energy, Division of Geology and Mineral Resources, 2018; William Lassetter, written commun., 2018).

More information about coal production in Virginia can also be found at the Virginia Department of Mines, Minerals, and Energy Division of Geology and Mineral Resources coal website at https://www.dmme.virginia.gov/ dgmr/coal.shtml and the Virginia Tech coal website at https://vept.energy.vt.edu/coal/Coal_Production.html (Virginia Department of Mines, Minerals, and Energy, Division of Geology and Mineral Resources, 2018).

\section{Coking Coals in Eastern Kentucky}

A series of six USBM county coking coal reports in the 1950s identified 24 coal beds that have coking properties in the eastern Kentucky part of the Central Appalachian basin (location 70 on figs. 2 and 11), including (in descending stratigraphic order): the Hindman, Coalburg, Flag, Winifrede, Hazard No. 6, and Haddix coal beds of the Middle Pennsylvanian Four Corners Formation of the Breathitt Group; the Wax, Fire Clay, and Whitesburg coal beds of the Hyden Formation of the Breathitt Group; the AmburgyWilliamson, D, Upper Elkhorn No. 3, Elkhorn Leader, Upper Elkhorn No. 2, Upper Elkhorn No. 1-Harlan, Lower Split of the Harlan, Lower Elkhorn, and Eagle coal beds of the Pikeville Formation of the Breathitt Group; and the Bingham, Millard, Hagy, Auxier, Upper Banner, and Elswick coal beds of the Grundy Formation of the Breathitt Group (Dowd and others, 1951c, d, 1952b; Wallace and others, 1953d, 1954c, d). Stratigraphic correlations between named coal beds and coal zones in Kentucky with those in Virginia and West Virginia are shown in Ruppert and others (2014).

Eble and Weisenfluh (2013) assessed the metallurgical coal resources of the following eight coal beds in eastern Kentucky (listed in descending stratigraphic order): the Fire Clay coal bed of the Middle Pennsylvanian Hyden Formation; the Upper Elkhorn No. 3, Upper Elkhorn No. 2, and Lower Elkhorn coal beds of the Lower to Middle Pennsylvanian Pikeville Formation; and the Clintwood, Glamorgan, Hagy, and Splash Dam coal beds of the Lower Pennsylvanian Grundy Formation (the Grundy Formation coals were only assessed in Pike County). They provided maps of the thickness of original and remaining resources for each of these beds, along with maps of structure contours, coal bed extent, and overburden thickness of the Lower Elkhorn coal bed. They also listed the amount of original and remaining resources for each bed for multiple thickness ranges on a county basis. Appendixes 15A and 15B show the total original and remaining resources, respectively, for the different thickness ranges for each bed as reported by Eble and Weisenfluh (2013). The Upper Elkhorn No. 3 had the largest amount of total original and remaining resources (8,001 and 6,219 mst, respectively), followed by the Lower Elkhorn (4,633 and 2,868 mst, respectively), the Fire Clay (4,164 and 2,459 mst, respectively), the Upper Elkhorn No. 2 (2,918 and 2,220 mst, respectively), and the Glamorgan (1,513 and 1,445 mst respectively). The Clintwood, Hagy, and Splash Dam all had less than $600 \mathrm{mst}$ total original and remaining resources. Eble and Weisenfluh (2013) estimated that with 5,465 mst remaining resources for all eight beds, and only 17 percent with greater than $42 \mathrm{in}$. of thickness, it would take approximately 35 years to deplete these resources, assuming a 50 percent recovery rate with $70 \mathrm{mst}$ of production per year. However, they believe it is unlikely that these resources will be totally extracted at this rate because of numerous access, bed continuity, roof quality, and coal quality challenges. 
Hower and others (1994) analyzed 13 coking coal samples from eight beds in six counties of eastern Kentucky, and 10 blends of coals made from two or more beds. The samples with the best coking properties came from the Pond Creek (Lower Elkhorn, Imboden) and the Upper Elkhorn No. 2 (Alma) beds in Pike County. They found that coal rank generally decreases from high-volatile A bituminous in the southeast near the Virginia border, to high-volatile $\mathrm{B}$ and $\mathrm{C}$ bituminous to the north and west of the study area (Floyd, Harlan, Knott, Letcher, Perry, and Pike Counties). They also found that coals higher in the section (for example, Hazard No. 8) have more ash, making them difficult to clean and less useful for coke making. Coals that are higher in the section were also more frequently extracted by surface mining, making them unsuitable for coking. One sample of the Alma bed in Perry County had high sulfur content ( 1.78 percent) with only 0.57 percent from pyrite, so removing the pyrite would still leave greater than 1 percent sulfur content. Two samples had greater than 8 percent ash, one from the Kellioka bed in Harlan County, and another from the Pond Creek bed in Pike County. These two samples also had greater than 0.06 percent $\mathrm{P}_{2} \mathrm{O}_{5}$ in the ash. All of the Pond Creek samples and one of the Upper Elkhorn No. 2 samples had medium to good sulfur content (less than 1 percent to less than 0.7 percent, respectively); two of the Pond Creek samples, and all three of the Upper Elkhorn No. 2 samples had low ash yield (6 percent); and all but one of the Pond Creek samples, and one of the Upper Elkhorn No. 2 samples had medium to good FSI values (greater than 6 and greater than 9, respectively).

In the Pond Creek bed in Pike and Martin Counties, Hower and Pollock $(1988,1989)$ and Hower and others $(1991$, 2005) reported sulfur contents ranging from 0.27 to 5.55 percent (most were less than 2 percent), and ash yields ranging from 1.47 to 58.30 percent (most were less than 20 percent). The highest sulfur contents were found at the top of the bed near the contact with roof rock. High ash yield was sometimes found near the upper contact as well, but also in bony layers within the bed. The Pond Creek bed ranges from high-volatile B bituminous in central Floyd County, to medium-volatile bituminous in eastern Pike County. (Hower and others, 1991). They listed CVs ranging from 34.3 to 35.5 megajoules per kilogram $(\mathrm{MJ} / \mathrm{kg})(14,700$ to $15,300 \mathrm{Btu} / \mathrm{lb})$, FSI values ranging from 2.1 to 7.12, and HGI values from 43.3 to 52.8.

The Fire Clay (Hazard No. 4) bed has several benches with varying amounts of sulfur content and ash yield (Greb and others, 1999). The middle and upper parts of the upper bench have low ash yield ( 4.5 to 5.7 percent) and sulfur content ( 0.9 percent), while the basal upper bench and lower bench have medium to high ash yield (7.7 to 22 percent) and sulfur content (1.4 to 1.6 percent).

The Harlan, Kellioka, and Darby coals of the Pikeville Formation in Harlan County (equivalent to the Upper Elkhorn No. 1, 3, and $31 / 2$ coals northwest of the Pine Mountain Thrust Fault, respectively) are high-volatile A bituminous coals (Johnston and others, 2015). Samples from the Harlan bed had 0.49 to 2 percent sulfur content (most were less than 1 percent) and 3.41 to 53.04 percent ash yield (most less than 20 percent). Ash yield of the Kellioka samples was generally less than 5 percent, and sulfur content was generally less than 0.9 percent. Their Darby samples had low ash yield and low sulfur content, except for one with 7.44 percent ash yield (Johnston and others, 2015).

The Blue Gem (Lower Elkhorn) and Jellico (Upper Elkhorn No. 1) coals of the Pikeville Formation are highvolatile A bituminous coal with low sulfur content (less than 1 percent) and ash yield (1 to 2 percent), VM ranging from 35.8 to 38.7 percent, and CV ranging from 33.59 to $34.24 \mathrm{MJ} / \mathrm{kg}$ (14,440 to $14,729 \mathrm{Btu} / \mathrm{lb}$ ) (Andrews and others, 2010; Craddock and others, 2017). These coals might be useful for production of anode coke used in aluminum production using a process in which the coals are dissolved, and the digested coal solution is calcined at high temperatures (Andrews and others, 2010; Craddock and others, 2017).

Prior to the 1980s, many Kentucky coal mines were owned by major steel producers or their subsidiaries, but in the 1990s demand for coking coal declined (Hower and others, 1994). The Pond Creek bed has been mined for both steam and metallurgical coal, with 84 mines producing almost 10.5 mst of coal in 1984, over 38 percent of the county's total (27.3 mst). In 2000, Pike County was the third most productive county for coal in the United States (Hower and others, 2005).

The U.S. Energy Information Administration (2018a) reported that $18.179 \mathrm{mst}$ of thermal and (or) coking coal was produced from 138 mines in 18 counties in eastern Kentucky in 2017 (9.959 mst from 51 underground mines, and $8.220 \mathrm{mst}$ from 87 surface mines) (appendix 9A). The largest producers were Pike, Perry, and Harlan Counties with 4.449 mst, $4.098 \mathrm{mst}$, and $3.479 \mathrm{mst}$, respectively (appendix 9A). They also reported that $5.292 \mathrm{mst}$ was metallurgical coal and 12.019 mst was non-metallurgical coal (appendix 9B).

As already described in the introduction to the Central Appalachian basin section above, the U.S. Energy Information Administration (2018a) reported production amounts and bed thicknesses of the Pocahontas No. 3, Eagle, Lower Elkhorn, Coalburg, Stockton-Lewiston, and Upper Elkhorn No. 3 coals in the Central Appalachian basin (in West Virginia, Virginia, and Kentucky) in 2017 (U.S. Energy Information Administration, 2018a) (appendix 9C). Go to the introductory section for the Central Appalachian basin above and appendix 9C for more information.

The Kentucky Energy and Environment Cabinet (2019) reported a total of 16.923 mst of coal produced from 18 counties in eastern Kentucky in 2018 (appendix 16A). The five highest producers were Pike, Perry, Harlan, Leslie, and Floyd Counties with totals of $4.171 \mathrm{mst}, 3.939 \mathrm{mst}, 3.120 \mathrm{mst}$, $1.281 \mathrm{mst}$, and $0.976 \mathrm{mst}$, respectively (Kentucky Energy and Environment Cabinet, 2019) (appendix 16A). Of the total $16.923 \mathrm{mst}, 8.968 \mathrm{mst}$ came from underground mines and $7.955 \mathrm{mst}$ came from surface mines (appendix 16B). 
One sample of coking coal from a mine in Floyd County, Kentucky, was collected in 2014 by Cortland Eble (Kentucky Geological Survey) and James Hower (University of Kentucky Center for Applied Energy Research) and was analyzed for this project. The sample came from the Upper Elkhorn No. 1 bed in the Frasier Branch Mine. The results of the analyses of this sample are listed in appendixes 2 to 7 and discussed in the "Samples Collected and Analyzed for This Report" and "Discussion of Results" sections of this report. A point location for this sample is shown on fig. 11. These data can also be downloaded from https://doi.org/10.5066/P9KFQOKM.

Analytical data from two samples of coking coal from mines in Pike and Owsley Counties, Kentucky, were shared with the USGS by David Cork of Corky's Coal Consultancy. The results of the analyses of these samples are listed in appendixes 2 to 8 and discussed in the "Sample Data From Other Sources" and "Discussion of Results" sections of this report. The locations of these two counties are shown on fig. 11. These data can also be downloaded from https://doi.org/10.5066/P9KFQOKM.

\section{Coking Coals in Northern Tennessee}

The State of Tennessee straddles the boundary between the Central and Southern Appalachian basin coal regions (Trippi and others, 2014a) (locations 71 and 72, respectively, on figs. 2, 11, and 12), with Anderson, Campbell, Claiborne, Fentress, Morgan, Overton, Putnam, and Scott Counties falling into the Central Appalachian basin coal region (location 71 on figs. 2 and 11), and Bledsoe, Cumberland, Franklin, Grundy, Hamilton, Marion, Rhea, Roane, Sequatchie, Van Buren, and White Counties falling into the Southern Appalachian basin coal region (location 72 on figs. 2 and 12). Counties in the Central Appalachian basin coal region are discussed in this section and counties in the Southern Appalachian basin coal region are discussed in the next section.

A series of nine USBM county coking coal reports in the 1950s identified 22 coal beds that have coking properties in the Central Appalachian basin coal region in northern Tennessee (location 71 on figs. 2 and 11), including (in descending stratigraphic order): the Rock Spring, and Petree coal beds of the Middle Pennsylvanian Vowell Mountain Formation; the Pewee, Walnut Mountain, Red Ash, and Big Mary coal beds of the Middle Pennsylvanian Redoak Mountain Formation; the Windrock, Upper Pioneer, Lower Pioneer, and Jordan coal beds of the Middle Pennsylvanian Graves Gap Formation; the Joyner coal bed of the Middle Pennsylvanian Indian Bluff Formation; the Jellico, Blue Gem, Coal Creek, and Poplar Creek coal beds of the Lower to Middle Pennsylvanian Slatestone Formation; the Hooper coal bed of the Lower Pennsylvanian Burnt Mill Shale of the Crooked Fork Group; the Christmas and Rex coal beds of the Lower Pennsylvanian Dorton Shale of the Crooked Fork Group; the Nemo coal bed of the Lower Pennsylvanian Rockcastle Conglomerate of the Crab Orchard Mountains
Group; the Sewanee coal bed of the Lower Pennsylvanian Whitwell Shale of the Crab Orchard Mountains Group; the Wilder coal bed of the Lower Pennsylvanian Signal Point Shale of the Gizzard Group; and the White Oak coal bed of the Lower Pennsylvanian Raccoon Mountain Formation of the Gizzard Group (Williams and others, 1954, 1955a, d, 1956a, b, c; Hershey and others, 1956c; Lowe and others, 1956).

The coal beds of northern Tennessee are almost all high-volatile A or B bituminous coals (Williams and others, 1954, 1955a, d, 1956a, b, c; Hershey and others, 1956c; Lowe and others, 1956), except for some Jellico bed samples in Claiborne County (Luther, 1959) and one White Oak bed sample in Fentress County (Lowe and others, 1956) with VM percentages that fall into the medium-volatile bituminous range (less than 31 percent). Average sulfur content in northern Tennessee coal beds is usually high (greater than 1 percent), but there are some instances of medium sulfur content (0.7 to 1.0 percent) in the Pewee, Red Ash, Big Mary, Windrock, Jordan, and Rex beds, and a few instances of low sulfur content (less than 0.7 percent) in the Petree, Pewee, Windrock, Poplar Creek, and White Oak beds (Williams and others, 1955d, 1956a, b, c; Hershey and others, 1956c; Luther, 1959). Ash yield ranges from high (greater than 10 percent) to low (less than 6 percent) in northern Tennessee coal beds, with a more equal split between low, medium, and high ash yield (Luther, 1959).

The U.S. Energy Information Administration (2018a) reported that only $0.431 \mathrm{mst}$ of thermal and coking coal was produced from six mines in Campbell (1) and Claiborne (5) Counties in northern Tennessee in 2017 (appendix 9A). Of this total, $0.329 \mathrm{mst}$ came from three underground mines, while the remaining $0.102 \mathrm{mst}$ came from three surface mines (appendix 9A). Claiborne County produced the most with $0.421 \mathrm{mst}$, while Campbell County produced only $0.010 \mathrm{mst}$ (appendix 9A). They also reported that $0.114 \mathrm{mst}$ was metallurgical coal and $0.290 \mathrm{mst}$ was non-metallurgical coal (appendix 9B).

\section{Coking Coals in the Southern Appalachian Basin Coal Region and Warrior Coal Field}

\section{Coking Coals in Southern Tennessee}

As mentioned above, Bledsoe, Cumberland, Franklin, Grundy, Hamilton, Marion, Rhea, Roane, Sequatchie, Van Buren, and White Counties of southern Tennessee fall in the Southern Appalachian basin coal region (location 72 on figs. 2 and 12). A series of seven USBM county coking coal reports in the 1950s named five coal beds that have coking properties in the southern Tennessee part of the Southern Appalachian basin coal region (location 72 in figs. 2 and 12), including (in descending stratigraphic order): the Morgan Springs and Lantana coal beds of the Lower Pennsylvanian Vandever Formation of the Crab Orchard Mountains Group, the Sewanee and Richland coal beds of the Lower Pennsylvanian 


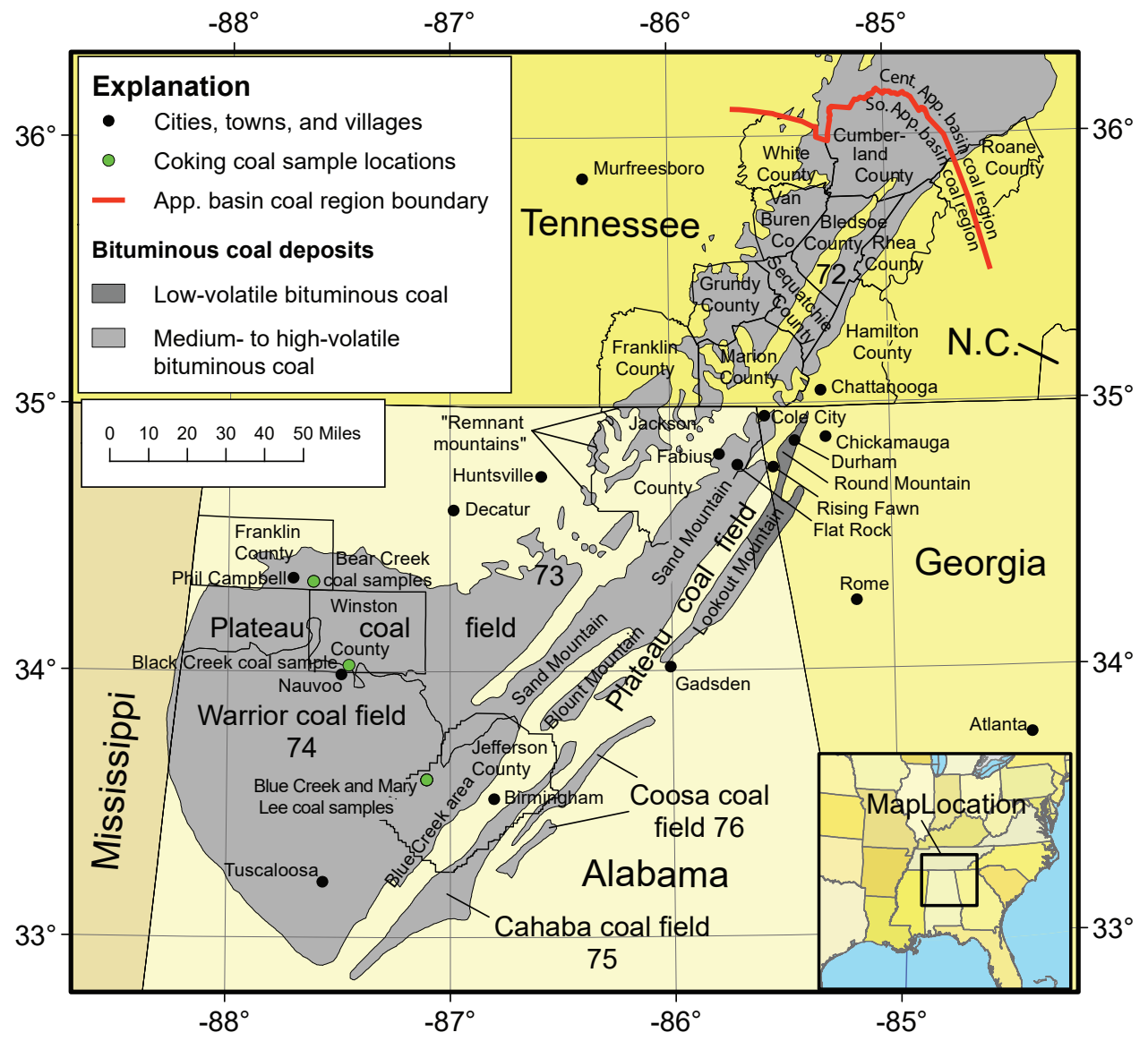

Figure 12. Map showing the locations of bituminous coal deposits in the States of Tennessee, Georgia, and Alabama in the Southern Appalachian basin coal region and the Warrior coal field. Numbers 72 to 76 correspond to coking coal deposit locations identified in the text and appendix 1 (table 1.1). Location 73 is located in both Alabama and Georgia. The green-filled circles are the locations of the seven coking coal samples from Franklin, Jefferson, and Winston Counties, Alabama, discussed in the text; sample analyses results are provided in appendixes 2 to 7 (table 2.1 to 7.1 ). These data can also be downloaded from https://doi.org/10.5066/P9KF0OKM. Abbreviations: App., Appalachian; Cent. App., Central Appalachian; Co., County; Med., medium; So. App., Southern Appalachian.

Whitwell Shale, and the Battle Creek coal bed of the Lower Pennsylvanian Raccoon Mountain Formation (Hershey and others, 1955, 1956a, b; Williams and others, 1955b, c; Williams and Hershey, 1956). Stratigraphic correlations between named coal beds and coal zones in Tennessee and those in Kentucky, Virginia, and West Virginia are shown in Ruppert and others (2014).

The coal beds of southern Tennessee are medium- or high-volatile A bituminous coals, with ash yield and sulfur contents that are medium to high (greater than 0.6 percent sulfur content; greater than 7 percent ash yield) (Hershey and others, 1955, 1956a, b; Williams and others, 1955b, c; Williams and Hershey, 1956; Luther, 1959).

The U.S. Energy Information Administration (2018a) reported no coal production from any counties in southern Tennessee in 2017.

\section{Coking Coals in Alabama and Georgia}

Northeastern Alabama has several dozen coal beds in the Lower Pennsylvanian Pottsville Formation in four different coal fields: (1) the Warrior coal field (the "Warrior coal basin" of Winston, 1990) of the Black Warrior basin (location 74 on figs. 2 and 12); (2) the Plateau coal field (the "Plateau coal region" of Winston, 1990) of the Appalachian basin (including the Sand Mountain, Lookout Mountain, Blount Mountain, and "Remnant Mountains" areas) (location 73 on figs. 2 and 12); (3) the Cahaba coal field of the Appalachian basin (location 75 on figs. 2 and 12); and (4) the Coosa coal field of the Appalachian basin (location 76 on figs. 2 and 12) (Culbertson, 1964) (fig. 12). Note that Winston (1990) included both the Warrior and Plateau coal fields of previous authors (Culbertson, 1964; Southern Railway System, 1972; Ward, 1984) in his redefined "Warrior coal field." He also 
coined a new term, "Warrior coal basin" (which is not the same as the "Black Warrior basin") for the area that previous authors had called the "Warrior coal field." We chose to follow the traditional definition of "Warrior coal field" used by Culbertson (1964), Southern Railway System (1972), and Ward (1984), and did not use the name "Warrior coal basin." The Sand Mountain and Lookout Mountain areas of the Plateau coal field extend into northwestern Georgia as well (Coleman and others, 1985).

The U.S. Energy Information Administration (2018a) reported that $12.861 \mathrm{mst}$ of thermal and (or) coking coal was produced from 30 mines in seven counties in Alabama in 2017 (appendix 9A). From this total, 10.491 mst came from seven underground mines, and $2.370 \mathrm{mst}$ came from 23 surface mines. Jefferson, Walker, and Tuscaloosa Counties were the largest producers with $7.433 \mathrm{mst}, 3.097 \mathrm{mst}$, and $2.081 \mathrm{mst}$, respectively (appendix 9A). They also reported that $10.996 \mathrm{mst}$ was metallurgical coal and $1.838 \mathrm{mst}$ was nonmetallurgical coal (appendix 9B).

The Alabama Department of Labor Office of Mine Safety and Inspection (2017) reported a total of $12.445 \mathrm{mst}$ of coal produced from 23 surface mines $(2.400 \mathrm{mst})$ and six underground mines (10.045 mst) in Franklin, Jefferson, Shelby, Tuscaloosa, Walker, and Winston Counties, Alabama, in their fiscal year 2017 (October 2016 to September 2017) (appendix 17). The biggest producers were Tuscaloosa, Jefferson, and Walker Counties with 6.434, 4.698, and 1.030 mst of coal, respectively (Alabama Department of Labor Office of Mine Safety and Inspection, 2017) (appendix 17).

No coal was produced in Georgia in 2017 (U.S. Energy Information Administration, 2018a).

Seven samples of coking coal from Alabama were collected by Cortland Eble and James Hower, of the Kentucky Geological Survey and the University of Kentucky Center for Applied Energy Research, respectively, and were analyzed for this project. Two samples came from the Bear Creek bed in the Knight Mine of Franklin County, Alabama, and one sample came from the Black Creek bed in the Old Union Mine of Winston County. The remaining four samples came from the Powhatan Mine in Jefferson County, three samples from the Mary Lee bed, and one sample from the Blue Creek Bed. The results of the analyses of these seven samples are listed in appendixes 2 to 7 and discussed in the "Samples Collected and Analyzed for This Report" and "Discussion of Results" sections of this report. These data can also be downloaded from https://doi.org/10.5066/P9KFQOKM. Point locations for these samples are shown on fig. 12.

\section{Coking Coals in the Warrior Coal Field in Alabama}

Culbertson (1964) identified 18 coal beds in the main part of the Warrior coal field (location 74 in figs. 2 and 12), and described four (listed in ascending order), the Black Creek, Mary Lee, Pratt, and Brookwood coal beds, as having good coking properties (low ash yield and low sulfur content), and determined that the Black Creek coals had the lowest ash yield and lowest sulfur content of any Warrior field coal beds. In Jefferson County, the Pratt coal bed, due to its persistence, thickness, excellent coking ability, and low ash yield and sulfur content, was the most important coking coal in Alabama. The total estimated remaining reserves (measured, indicated, and inferred) of the Black Creek, Mary Lee, Pratt, and Brookwood coal beds in 1958 were 1,679.4 mst, 5,750.6 mst, 2,298.5 mst, and $151.4 \mathrm{mst}$, respectively (Culbertson, 1964).

In the Blue Creek area (also called the Pratt coal basin) on the east side of the Warrior coal field (see fig. 12), Culbertson (1964) named six coal beds, and described five (in descending order), the Blue Creek, J, K, L, and M coal beds, as having good coking properties (low ash yield and sulfur content). The Blue Creek coal bed has been used extensively as a coking coal, but by 1964 it was mostly mined-out. In 1958, the total known recoverable resources of the Blue Creek coal bed were $56.2 \mathrm{mst}$ (Culbertson, 1964).

In 2017, the Blue Creek coal bed was the second most productive coal bed in the Appalachian basin and the ninth most productive bed in the United States with $9.962 \mathrm{mst}$ produced (U.S. Energy Information Administration, 2018a) (appendix 9C). Of this production, $9.801 \mathrm{mst}$ came from underground mines and $0.161 \mathrm{mst}$ came from surface mines (appendix 9C). Mined thicknesses ranged from 16 to 64 in., with an average of 52 in. (appendix 9C).

Southern Railway System (1972) listed 23 coal beds in seven coal groups in the Warrior coal field. Eleven beds (in ascending order) - the Black Creek and Jefferson beds of the Black Creek group; the Blue Creek, Mary Lee, and New Castle beds of the Mary Lee group; the America, Fire Clay, and Pratt beds of the Pratt group; and the Johnson (or Carter), Milldale, Clements, and Brookwood beds of the Brookwood group - were described as important. Most of them were high-volatile A bituminous coal with moderate to low ash yield and low sulfur content.

Ward (1984) listed 35 coal beds in seven coal groups in the Warrior coal field, and described seven (in ascending order), the Black Creek bed of the Black Creek group, the Blue Creek and Mary Lee beds of the Mary Lee group, the Pratt bed of the Pratt group, and the Carter, Milldale, and Brookwood beds of the Brookwood group, as consistent producers of coking quality coal.

Winston (1990) presented maps of extent, VM, CV, ash yield, and sulfur content for the following coal beds listed in ascending stratigraphic order: Black Creek, Mary Lee, Pratt, Cobb, Gwin, Utley, and Brookwood coal groups in the Warrior coal field (his "Warrior coal basin"). The extents of these coal groups become smaller with increasing elevation in the stratigraphic section, with the Black Creek having the largest extent, and the Brookwood, the smallest. The Mary Lee, Pratt, Cobb, and Utley groups had low ash yields (less than 12 percent) in the southeastern part of the Warrior coal field (roughly equivalent to the Blue Creek area of Culbertson [1964]). Sulfur contents for the four coal groups in the southeast area were also lower (relative to values in the rest of the coal field), with the Mary Lee having less than 1 percent sulfur 
content, the Pratt and Cobb groups less than 2 percent sulfur content, and the Utley less than 3 percent sulfur content. In the remaining part of the Warrior coal basin, the ash yield and sulfur content of these coal groups were moderate to high with much variability. The Black Creek coal group generally had ash yields of 6 percent or less throughout its extent, and sulfur contents of 2 percent or less around the edges of the Warrior coal field, but higher contents in the center. The Gwin coal group was generally high in sulfur content (greater than 2 percent) and ash yield (greater than 18 percent) throughout its extent, and the Brookwood group generally had less than 12 percent ash yield and less than 2 percent sulfur content throughout its extent. Stratigraphic correlations between named coal beds and coal zones in the Southern Appalachian coal basin in Alabama with those in Tennessee, Kentucky, Virginia, and West Virginia are shown in Ruppert and others (2014).

\section{Coking Coals in the Plateau Coal Field in Alabama}

Coulter (1947) named six coal beds in the Lookout Mountain section of the Plateau coal field in Alabama (location 73 on figs. 2 and 12) (in ascending order): the Castle Rock, Underwood, Upper Cliff No. 2, Upper Cliff No. 1 (or Hill), Sewanee, and Tatum coal beds. Coulter (1947) discussed the lateral extent and the coal quality of the six coal beds and his results are discussed below. The Tatum and Sewanee beds are limited in their extents to the highest hills on Lookout Mountain, and were therefore only mined to a small extent, and never prospected. Analyses of coal samples from these beds showed the Sewanee to be a low-volatile bituminous coal with the highest coking grade of all six beds. The Upper Cliff No. 1 was a low- to medium-volatile bituminous highgrade coking coal with a wide extent on Lookout Mountain and was the most extensively mined and prospected of the six beds. Analyses showed the Upper Cliff No. 1 coal bed to be highly agglutinating, high in FC and CV, and low in VM, ash, and sulfur contents. The Upper Cliff No. 2 was slightly lower in grade than the Upper Cliff No. 1, and the Castle Rock and Underwood beds had the lowest coking grade. The lower three beds were mined to only a small extent.

Culbertson (1964) listed the same six coal beds as Coulter (1947) in the Lookout and Sand Mountain areas of the Plateau coal field in Alabama (see fig. 12) and described the Upper Cliff No. 1 coal bed as having good coking properties (moderate ash yield and low sulfur content). The total known recoverable resources of the Upper Cliff No. 1 coal bed in 1958 were 7.3 mst (Culbertson, 1964).

Shotts and Riley (1966) estimated approximately $73 \mathrm{mst}$ of coking coal reserves from the Underwood coal bed near the towns of Fabius and Flat Rock in Jackson County, Alabama, on Sand Mountain in the Plateau coal field. The conclusions of Shotts and Riley (1966) are discussed below. Fifty-five percent (40 mst) of the Underwood coal bed was overlain by less than $60 \mathrm{ft}$ of overburden, making it amenable to strip mining. High ash yield and moderately high sulfur content were reducible by washing. Coals of the Sand Mountain area with greater than $15,000 \mathrm{Btu} / \mathrm{lb}$ on a dry mineral-matter-free (dmmf) basis (high-volatile A bituminous coal or higher in rank) were considered suitable for coking, and were suggested for potential use by steel and foundry industries in nearby Gadsden, Alabama, and Chattanooga, Tennessee. However, no coals of the Plateau coal field were being produced in 1966, and no significant amounts of coal had ever been produced in prior years, due to the thin and irregular thicknesses of coal beds in this area (Shotts and Riley, 1966).

Southern Railway System (1972) listed the same six coal beds as Coulter (1947) and Culbertson (1964) on Lookout and Sand Mountains in the Plateau coal field in Alabama, and considered the Underwood and Upper Cliff No. 2 beds important. They reported that the Underwood coal bed was mediumvolatile bituminous coal with high ash yield, and the Upper Cliff No. 2 bed was medium- to low-volatile bituminous with high ash yield and high- to low-sulfur content. Ward (1984) listed 11 coal beds on Sand Mountain, Lookout Mountain, and the "remnant mountains of Jackson County" in Alabama, and described two, the Sewanee and Upper Cliff No. 1 beds, as consistent producers of coking quality coal.

In the Blount Mountain section of the Plateau coal field in Alabama (fig. 12), Culbertson (1964) listed 10 coal beds, with one, the Altoona coal, having good coking properties (low ash yield and low sulfur content). The total estimated remaining reserves of the Altoona coal bed in 1958 were 14.4 mst. Southern Railway System (1972) considered two coal beds in the Blount Mountain area, the Swansea (or Inland or Jagger) and the Altoona (or Carnes) coal beds, to be important. They found that the Swansea coal bed is high-volatile A bituminous coal with high ash yield and low sulfur content and the Altoona was considered a good coking coal with low ash yield and low sulfur content. Ward (1984) listed 12 coal beds in the Blount Mountain section of the Plateau coal field, and described one, the Lowe-Harris (or Swansea, or Rosa) bed, as a consistent producer of coking quality coal.

\section{Coking Coals in the Plateau Coal Field in Georgia}

Gildersleeve (1948) listed three commercially-mined coal beds of the Lower Pennsylvanian Pottsville Formation on Sand Mountain in the Plateau coal field, Georgia (location 73 on figs. 2 and 12) (in ascending order): the Rattlesnake, Dade, and Etna coal beds. All three were medium-volatile bituminous coal. Gildersleeve (1948) reported on the quality and mining history of the Plateau coal field and they are presented below. The Etna coal was used for making high-grade coke. In the Round Mountain part of Lookout Mountain (near Durham, Georgia), Gildersleeve (1948) listed three commerciallymined coal beds (in ascending order): the No. 4, No. 5 (or Dade), and A coal beds. The No. 4 and No. 5 beds are lowvolatile bituminous coals, generally having low ash yield (less than 10 percent) and low sulfur content (less than 1 percent) and CV greater than or equal to $13,000 \mathrm{Btu} / \mathrm{lb}$. The A coal is higher in ash yield and sulfur content and lower in CV than the 
No. 4 and No. 5 beds. Coke ovens in Chickamauga, Cole City, and Rising Fawn, Georgia, used coal mainly from the Round Mountain mines. Peak production occurred in 1903 with 416,000 mst, dropping to only 21,250 mst in 1944.

Coleman and others (1985) named 14 coal beds of the Lower Pennsylvanian Gizzard and Crab Orchard Mountains Groups on Lookout and Sand Mountains in the Plateau coal field, Georgia, with eight having low ash yield (less than 10 percent) and (or) low sulfur content (less than 1 percent) (in ascending order): the No. 9A, No. 9, No. 8, No. 6, No. 5A, No. 5 , No. 4 , and No. 3 . The No. 3 bed had low sulfur content and low ash yield and was the thickest bed on Lookout Mountain; it had been the most consistent producer in northwest Georgia prior to 1985. Despite having low ash yield and low sulfur content, the No. 5 bed was considered too thin to be of economic interest (Coleman and others, 1985).

\section{Coking Coals in the Cahaba Coal Field in Alabama}

In the Cahaba coal field of the Appalachian basin (location 75 on figs. 2 and 12), Culbertson (1964) listed 36 coal beds, and described six of them, the Pump, Youngblood (or Coke), Clark (or Woodstock), Gholson, Thompson, and Helena beds, as having low sulfur content and low ash yield. Four others, the Nunally, Harkness, Montevallo, and Maylene coal beds had low sulfur content, but their ash yield values were moderate to high. Shotts (1971) described the Woodstock and Coke beds as "weakly coking" and stated that the Woodstock and Thompson coals were "easy to prepare for steam or coking purposes."

Southern Railway System (1972) reported 35 coal beds (or coal groups) in the Cahaba coal field. Ten beds (or groups), the Gould group, Nunally group, Harkness bed, Wadsworth (or Waterworks) bed, Big Bone (or Coke Oven) bed, lower and upper Pump (or Alice and Jones) beds, Clark (or Woodstock) bed, Gholson bed, Upper and Lower Thompson beds, and the Lower Maylene bed, were considered important. They report that most of them were high-volatile A bituminous coal with moderate to low ash yield and low sulfur content except the Big Bone which was high in ash. Ward (1984) listed 65 coal beds in the Cahaba coal field, and described four, the Woodstock (or Clarke), Coke, Atkins, and Thompson coal beds, as consistent producers of coking quality coal.

Coal production from the Cahaba field was variable in between 1978 and 1993 (Pashin and others, 1995), from a high of 776 thousand short tons (tst) in 1980 to a minimum of only 18 tst in 1987.

\section{Coking Coals in the Coosa Coal Field in Alabama}

The Coosa coal field (location 76 on figs. 2 and 12) is the least important coal field in Alabama and has had very limited production (Culbertson, 1964). Rothrock (1949) listed 14 mined coal beds in the Fairview and Coal City coal basins of the northeastern Coosa coal field of the southern Appalachian basin. Some had been used for making metallurgical coke, but most had high sulfur content and high ash yield, and were therefore considered unsuitable. Average ash values for samples from five coal beds (in descending order), the Coal City, Broken Arrow, Marion, Gann, and Upper Chapman, ranged between 4.9 to 9.2 percent, but average sulfur content for only the Coal City and Broken Arrow samples was less than 1 percent. For thicknesses greater than or equal to 20 in. in the Coal City, Broken Arrow, and Marion coal beds, approximately 1.3, 1.3 , and $1.1 \mathrm{mst}$ of reserves of coal, respectively, were present in the Fairview and Coal City parts of the Coosa coal field in 1949 (Rothrock, 1949).

In the northeastern part of the Coosa coal field of the Appalachian basin, Culbertson (1964) listed 14 coal beds, but only described the Coal City coal bed as having low sulfur content and low ash yield. In the southwestern part of the Coosa coal field he listed eight coal beds, none of which he described as having low sulfur content or low ash yield. The total estimated remaining reserves (measured, indicated, and inferred) of the Coal City coal bed in 1958 was $1.3 \mathrm{mst}$.

Southern Railway System (1972) reported 18 coal beds in the Coosa coal field. Twelve beds, the Upper and Lower Chapman, Fairview, Higginbotham, Gann, Brown, Marion, Broken Arrow, Inman, Coal City, Hammond, and Martin beds, were considered more important, but the Gann and Brown beds were discontinuous, and therefore uneconomic, and the Inman bed was probably mined-out. Ward (1984) listed 21 coal beds in the Coosa coal field, and described one, the Inman, as a consistent producer of coking quality coal.

\section{Samples Collected and Analyzed for This Report}

Fourteen coal samples were collected for analysis in this report, including seven from Alabama and one from Kentucky (in cooperation with the Kentucky Geological Survey and the University of Kentucky Center for Applied Energy Research), three from Oklahoma (in cooperation with the Oklahoma Geological Survey), and three from Arkansas (in cooperation with the Arkansas Geological Survey). Appendix 2 lists the sample locations and identification information for each sample, including State, field identification, county, sampling date, decimal longitude and latitude, formation, bed and (or) split, mine name and (or) company name, mine type, method of sample collection, thickness, coal field name, age, and additional descriptive comments. These data can also be downloaded from https://doi.org/10.5066/P9KFQOKM.

Proximate and ultimate analyses, $\mathrm{CV}$, forms of sulfur, equilibrium moisture (EQM), residual moisture (RM), air-dry loss (ADL), true specific gravity (TSG), and FSI for the samples were determined by Geochemical Testing Inc. of Somerset, Pennsylvania (appendixes 3 and 6). Major, minor, and trace element analyses were done by Activation Laboratories, Ltd., of Ancaster, Ontario (appendixes 4 and 5). Gieseler plastometer and ASTM dilatometer tests were run by CoalTech Petrographic Associates, Inc. of Murrysville, 
Pennsylvania (appendix 6). Petrographic attributes were determined by Cortland Eble and James Hower of the Kentucky Geological Survey and the University of Kentucky Center for Applied Energy Research, respectively, in Lexington, Kentucky (appendix 7). These data can also be downloaded from https://doi.org/10.5066/P9KFQOKM.

\section{Sample Data from Other Sources}

Data from previously analyzed samples were obtained from three other sources:

1. An anonymous mining company in Pennsylvania shared data for 13 coking coal samples from five coal beds in five counties in Pennsylvania;

2. Richard Kruse, Senior Research Engineer, of ArcelorMittal USA, East Chicago, Indiana, shared data for 40 coking coal samples from six coal beds in one mine in McDowell County, West Virginia, and;

3. David Cork, Technical Director and Principal Design Engineer of Corky's Carbon Consultancy in Mayfield, New South Wales, Australia, supplied data for 22 coking coal samples in 2010 (15 samples from seven counties in West Virginia, five samples from two counties in Virginia, and two samples from Kentucky).

At the request of these sources, we agreed to report only the State and county names for these locations, and not to report the mine name or latitude and longitude values.

Appendix 2 lists the sample locations and identification information for each sample, including State, field identification, county, sampling date, decimal longitude and latitude (if disclosed), formation, bed and (or) split, mine name and (or) company name, mine type, method of sample collection, thickness, coal field name, age, and additional descriptive comments. These data can also be downloaded from https://doi.org/10.5066/P9KFQOKM.

Data from proximate and ultimate analyses, $\mathrm{CV}$, forms of sulfur, equilibrium moisture (EQM), residual moisture (RM), air-dry loss (ADL), true specific gravity (TSG), and FSI for the samples are listed in appendix 3. Data from major, minor, and trace element analyses are listed in appendixes 4 and 5 . Gieseler plastometer and ASTM dilatometer test data are listed in appendix 6. Organic petrology data are listed in appendix 7. Data from miscellaneous other tests are listed in appendix 8. These data can also be downloaded from https://doi.org/ 10.5066/P9KFQOKM.

\section{Discussion of Results}

Although it is tempting to evaluate the coal samples that were collected for this study (presented in appendixes 2 to 8 ) using the data quality ranges presented in tables 1 to 3 , one must remember that the ranges in those tables were intended for use only with washed U.S. coals, not raw or otherwise pre-processed coal samples (Kevin DeVanney, CoalTech Petrographic Associates, Inc., oral commun., 2018). Since none of the samples that were collected for this study were washed, tables 1 to 3 are not used in this report to evaluate the analytical data of the samples collected for this report. Data from raw coal samples that fall outside acceptable quality ranges shown in tables 1 to 3 will probably be improved after washing and (or) blending with other coals. Nearly all coals used for cokemaking today are blended with other coals to produce an end-product that meets the needs of the coke plant with respect to multiple properties. Any sample of a single coal bed (like the samples collected for this report) will almost certainly not be used by itself to make coke. Therefore, we feel it is misleading to evaluate the chemical, rheological, petrographic, and other miscellaneous data determined in the analyses of samples collected for this report using the property ranges presented in tables 1 to 3 .

\section{Alabama Coal Samples}

Seven Alabama coking coal samples were collected for this report by Cortland Eble and James Hower (appendix 2). Two samples were collected from the Lower Pennsylvanian (Morrowan) Bear Creek coal bed in the Pottsville Formation at the Knight Mine about five miles east of the town of Phil Campbell, in Franklin County, Alabama (fig. 12, appendix 2). One sample was from the bottom bench of the coal bed, and one from the top bench. Another sample was collected from the Lower Pennsylvanian (Morrowan) Black Creek coal bed in the Pottsville Formation at the Old Union Mine about three miles northeast of the town of Nauvoo, in Winston County, Alabama (fig. 12, appendix 2). The remaining four samples came from the Lower Pennsylvanian (Morrowan) Blue Creek and Mary Lee coal beds in the Pottsville Formation at the Powhatan Mine about 20 miles west of Birmingham, in Jefferson County, Alabama (fig. 12, appendix 2). One sample was collected from the Blue Creek coal bed, one from the bottom split of the Mary Lee coal bed, and two from the top split of the Mary Lee coal bed (one from the lower bench and one from the upper bench). A single composite sample was created representing both the top and bottom benches of the Bear Creek coal bed for chemical and rheological analyses (appendixes 3 to 6), but petrographic analyses were performed on separate samples from the top and bottom benches (appendix 7). Similarly, a composite sample of the top and bottom benches of the top split of the Mary Lee coal bed was made for chemical and rheological analyses, but petrographic analyses were performed on separate samples of the two benches. Also, a duplicate split of the Blue Creek coal bed sample was run as a quality assurance check for the major, minor, and trace element analyses ("Blue Creek duplicate (Sample A)" in appendixes 4 and 5). The values for these two Blue Creek samples were very close to each other indicating consistency and reproducibility of results. 
The Bear Creek sample was high-volatile B bituminous in rank (based on VM [dmmf] and CV [mmmf] as described in ASTM standard D388). The Black Creek and Mary Lee bottom split samples were both high-volatile A bituminous, and the Blue Creek and Mary Lee top split samples were both medium-volatile bituminous (appendix 3). Ash yield in the Alabama samples was highly variable with the Blue Creek sample having only 4.56 percent ash (dry), while the Mary Lee bottom split sample had 17.39 percent ash (dry) (appendix 3). Sulfur content ranged from a low of 0.91 percent (daf) in the Black Creek sample to a high of 2.07 percent (daf) in the Mary Lee top split sample (appendix 3). These data can also be downloaded from https://doi.org/10.5066/P9KFQOKM.

Major element analyses for the Alabama samples were also quite variable (appendix 4). All six Alabama samples had $\mathrm{Al}_{2} \mathrm{O}_{3}, \mathrm{~K}_{2} \mathrm{O}+\mathrm{Na}_{2} \mathrm{O}, \mathrm{MgO}, \mathrm{SO}_{3}, \mathrm{SiO}_{2}$, and $\mathrm{TiO}_{2}$ percentages that fell in the ranges for typical bituminous ash yields in the United States (table 4) (Riley, 2007). However, the two Blue Creek samples were extremely high in $\mathrm{Fe}_{2} \mathrm{O}_{3}$ (38.17 and 39.32 percent), and the Mary Lee samples had very low $\mathrm{CaO}$ content (less than 1 percent) (appendix 4). The high $\mathrm{Fe}_{2} \mathrm{O}_{3}$ and elevated $\mathrm{SO}_{3}$ contents in the Blue Creek samples relative to the other four Alabama samples likely indicate the presence of pyrite. $\mathrm{SiO}_{2}$ and $\mathrm{Al}_{2} \mathrm{O}_{3}$ contents were low relative to the other four Alabama samples (appendix 4), likely indicating lower quartz and clay content. The acid-to-base ratios for the Blue Creek samples were also much lower than in the other four samples as a result of the high $\mathrm{Fe}_{2} \mathrm{O}_{3}$ values, despite relatively low values of $\mathrm{TiO}_{2}, \mathrm{CaO}, \mathrm{K}_{2} \mathrm{O}, \mathrm{MgO}$, and $\mathrm{Na}_{2} \mathrm{O}$. The Bear Creek and Mary Lee top split samples had much higher $\mathrm{P}_{2} \mathrm{O}_{5}$ contents in the ash $(0.94$ percent and 0.64 percent, respectively) than the other four Alabama samples (which ranged between 0.09 to 0.15 percent).

Most Alabama samples had pCSR values in the high 20 s to low 40s, but the Bear Creek sample had an extremely low value (-6.9) as a result of high ash and low plastic range values.

FSI values of 5 and 0.5 in the Black Creek and Bear Creek samples, respectively, indicate poor caking ability (Zimmerman, 1979), while FSI values of 8 and 9 for the Blue
Creek and Mary Lee samples indicate very good to excellent caking ability (appendix 6). The Bear Creek and Black Creek samples had very low Gieseler maximum fluidity values, ranging from 1 to $7 \mathrm{ddpm}$, while the Blue Creek and Mary Lee samples had high Gieseler maximum fluidity values, ranging from 4,225 to 13,876 ddpm (appendix 6). The plastic range values for the Bear Creek and Black Creek samples varied from 14 to $44{ }^{\circ} \mathrm{C}$, while the Blue Creek and Mary Lee samples had plastic range values ranging from 84 to $89^{\circ} \mathrm{C}$ (appendix 6). The Blue Creek and Mary Lee samples had values for dilatation ranging from 171 to 261 percent, while the Black Creek sample had a dilatation value of -10 percent; dilatation could not be calculated for the Bear Creek sample (appendix 6).

As mentioned above, the Bear Creek bottom and top benches were analyzed separately for petrography (appendix 7). Also, the lower and upper benches of the Mary Lee top split were analyzed separately for petrography. Mean $R_{0} \max$ values for the Bear Creek and Black Creek samples ranged from 0.76 to 0.82 percent, while the mean $R_{0} \max$ values for the Blue Creek and Mary Lee samples ranged between 1.00 and 1.14 percent (appendix 7). All seven Alabama samples were classified as high-volatile B bituminous using mean $\mathrm{R}_{0}$ max values as per Davis (1978) (appendix 7).

The Alabama samples had pCSF values ranging from 5 to 61 (appendix 7).

\section{Arkansas Coal Samples}

Three Arkansas coking coal samples were provided by Bill Prior of the Arkansas Geological Survey (appendix 2). All three came from the Middle Pennsylvanian (Desmoinesian) Lower Hartshorne coal bed in the McAlester Formation at the Sebastian Mine near the town of Hartford in Sebastian County, Arkansas (fig. 8). They represent three parts of the bed, the first from the lower 20 in., the second from 20 to $28 \mathrm{in}$. above the base, and the third from 28 to $42 \mathrm{in}$.

The sample representing the lower part of the Lower Hartshorne bed was medium-volatile bituminous in rank (based on VM [dmmf] and CV [mmmf]), while the samples for the middle and upper parts of the Lower Hartshorne bed

Table 4. List of the typical range of percentages for major element oxides in bituminous coals of the United States (data from Riley, 2007).

\begin{tabular}{cc}
\hline Major element oxide & Typical range of percentages \\
\hline $\mathrm{SiO}_{2}$ & $20-60$ \\
$\mathrm{Al}_{2} \mathrm{O}_{3}$ & $10-35$ \\
$\mathrm{Fe}_{2} \mathrm{O}_{3}$ & $5-35$ \\
$\mathrm{CaO}$ & $1-20$ \\
$\mathrm{MgO}$ & $0.3-4$ \\
$\mathrm{TiO}_{2}$ & $0.5-2.5$ \\
$\mathrm{Na}_{2} \mathrm{O}+\mathrm{K}_{2} \mathrm{O}$ & $1-4$ \\
$\mathrm{SO}_{3}$ & $0.1-12$ \\
\hline
\end{tabular}


were both low-volatile bituminous (appendix 3). Ash yield in the Arkansas samples ranged from 8.66 percent (dry) for the middle part of the Lower Hartshorne bed to 12.27 percent ash (dry) in the lower part (appendix 3). Sulfur content ranged from a low of 0.69 percent (daf) in middle part of the Lower Hartshorne sample to 0.92 percent (daf) in the upper part (appendix 3).

Major element analyses for the Arkansas samples were quite variable (appendix 4). The samples for the lower and middle parts of the Lower Hartshorne had very low $\mathrm{Al}_{2} \mathrm{O}_{3}$ (2.95 to 3.27 percent), $\mathrm{K}_{2} \mathrm{O}+\mathrm{Na}_{2} \mathrm{O}$ ( 0.42 to 0.59 percent), and $\mathrm{SiO}_{2}$ percentages (6.91 to 7.7 percent) relative to the normal ranges for typical bituminous ash samples in the
United States (appendix 4) (Riley, 2007). However, they were also very high in $\mathrm{Fe}_{2} \mathrm{O}_{3}$ (greater than 42.9 percent) and $\mathrm{MgO}$ (5.34 to 6.32 percent) (appendix 4). The high $\mathrm{Fe}_{2} \mathrm{O}_{3}$ content may be due to the presence of much siderite $\left(\mathrm{FeCO}_{3}\right)$ in the sample, which was visible in photomicrographs (fig. 13). These samples had high $\mathrm{SO}_{3}$ content (10.3 to 14.4 percent) as well, which may indicate the presence of pyrite (appendix 4). The acid-to-base ratio could only be calculated for the upper part of the Lower Hartshorne bed, which had a value of 1 (appendix 4). $\mathrm{P}_{2} \mathrm{O}_{5}$ contents in the ash of all three beds were 0.04 (lower part), 0.04 (middle part), and 0.03 (upper part) (appendix 4).

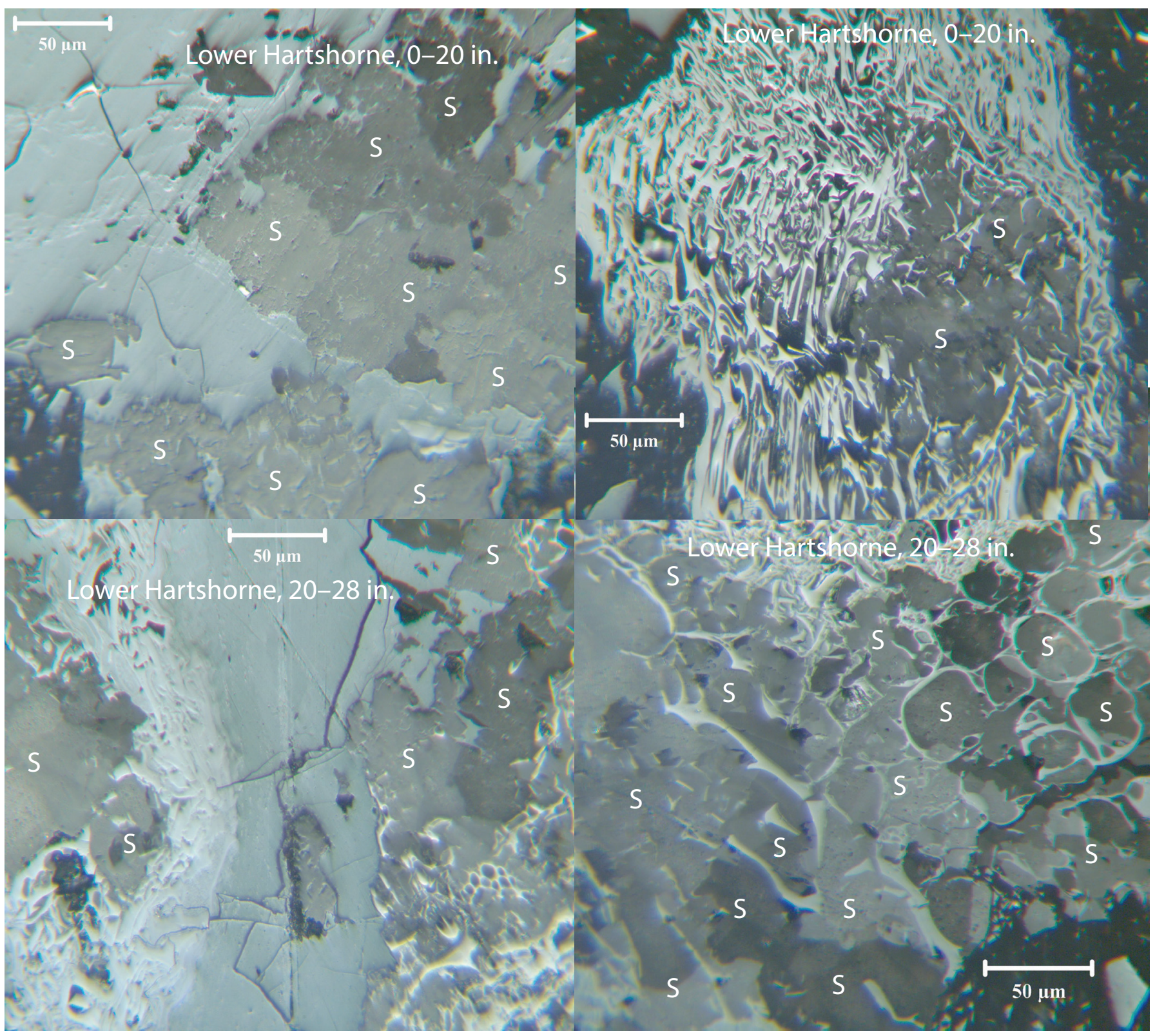

Figure 13. Photomicrographs of siderite $(S)$ infilling areas between coal macerals in samples from the Lower Hartshorne bed in Arkansas. Abbreviations: in., inches; $\mu \mathrm{m}$, microns. 
We were able to calculate Alkali Index and pCSR values for only one Arkansas sample (appendix 4). It had a pCSR value of -54.9 as a result of a high Alkali Index (11.9) caused by high ash, $\mathrm{CaO}, \mathrm{Fe}_{2} \mathrm{O}_{3}$, and $\mathrm{MgO}$.

FSI values for all three Arkansas samples were 9 (appendix 6), indicating excellent caking ability (Zimmerman, 1979). Gieseler maximum fluidity values ranged from 51 to $180 \mathrm{ddpm}$, and plastic range values ranged from 59 to $67^{\circ} \mathrm{C}$ (appendix 6). Dilatation values ranged from 40 to 96 (appendix 6).

Mean $\mathrm{R}_{\mathrm{o}}$ max values for the three Arkansas samples ranged from 1.69 to 1.71 , placing them all in the low-volatile rank (based on mean $R_{0} \max$ [Davis, 1978]) (appendix 7).

The Arkansas samples had pCSF values ranging from 41.5 to 62 (appendix 7).

\section{Oklahoma Coking Coal Samples}

Three samples of coking coal from Oklahoma were provided by Brian Cardott of the Oklahoma Geological Survey. All three of them came from Farrell-Cooper Mines in LeFlore County (fig. 8, appendix 2). One (Lower Hartshorne OPL 1344) was a grab sample from the Middle Pennsylvanian (Desmoinesian) Lower Hartshorne coal bed in the Hartshorne Formation of the Krebs Group at the Rock Island Mine near the town of Rock Island, Oklahoma. The other two (Upper Hartshorne OPL 1435 and OPL 1436) are channel samples from the Upper and Lower Hartshorne coal beds in the Hartshorne Formation at the Bull Hill Mine a few miles west of the town of Wister, Oklahoma. The Rock Island Mine sample was collected in May of 2009, and the Bull Hill Mine samples were collected in May 2013. Each sample was placed in storage after collection. Portions of the samples were sent to the USGS by Brian Cardott in September of 2014 for analyses. Duplicate sample splits of the Rock Island Mine sample (Sample B) and the Lower Hartshorne sample from the Bull Hill Mine (Sample C), were run as a quality assurance check for the major, minor, and trace element analyses (appendixes 4 and 5). The results for the duplicate samples were very close to their corresponding samples, indicating consistency and reproducibility of results. FSI was the only rheological test run on these samples (appendix 6) because the samples had been stored for one to five years.

The Rock Island Mine sample (Lower Hartshorne OPL 1344) was a low-volatile bituminous coal (based on VM [dmmf] and CV [mmmf]), while the Bull Hill Mine samples (Upper Hartshorne OPL 1435 and OPL 1436) were mediumvolatile bituminous coal (appendix 3). Ash yield in the Oklahoma samples ranged from 2.46 to 4.99 percent (dry) (appendix 3). Sulfur content ranged from a low of 0.71 percent (daf) in the Rock Island Mine sample, to 1.04 percent in the Upper Hartshorne Bull Hill Mine (appendix 3).

Major element analyses for the Oklahoma samples were quite variable (appendix 4). The sample from the Rock Island Mine (Lower Hartshorne OPL 1344 and OPL 1344 duplicate
[Sample B]) and the Upper Hartshorne sample from the Bull Hill Mine (Upper Hartshorne OPL 1435) had low $\mathrm{K}_{2} \mathrm{O}+$ $\mathrm{Na}_{2} \mathrm{O}$ (less than or equal to 1 percent), and $\mathrm{SiO}_{2}$ percentages ( 9.78 to 19.1 percent) relative to the normal ranges for typical bituminous ash yield in the United States (appendix 4) (Riley, 2007). The Rock Island Mine samples were high in $\mathrm{MgO}$ (12.3 to 12.4 percent) relative to typical bituminous ash samples (appendix 4) (Riley, 2007). All three samples had very high $\mathrm{SO}_{3}$ values (12.7 to 20.6 percent) relative to the normal ranges for typical bituminous ash samples in the United States (appendix 4) (Riley, 2007). Except for those described above, the percentages of major element oxides in all the Oklahoma samples fell in the ranges for typical bituminous ash samples in the United States (appendix 4) (Riley, 2007). $\mathrm{P}_{2} \mathrm{O}_{5}$ contents in the ash of the Oklahoma samples ranged from 0.126 to 0.653 percent (appendix 4).

We were unable to calculate pCSR values for any Oklahoma samples because they had no Gieseler plastic range values (appendix 4).

FSI values for all the Oklahoma samples were either 5 or 9 (appendix 6) indicating poor or excellent caking ability (Zimmerman, 1979). As indicated above, Oklahoma samples were not tested for Gieseler plasticity or dilatation because they were unsuitable for these tests.

Mean $\mathrm{R}_{0}$ max values for the Oklahoma samples ranged from 1.11 to 1.54 (appendix 7), which places them in lowto medium-volatile rank (Davis, 1978). However, these $R_{0}$ values were measured on the coal samples after several years of storage. Mean $R_{0}$ max values of 1.22 to 1.83 percent were measured soon after the samples were collected by Brian Cardott in 2014. Using the mean $\mathrm{R}_{0}$ max values measured by Brian Cardott, the samples would still be considered low- to medium-volatile bituminous rank.

The Oklahoma samples had pCSF values ranging from 48 to 63 (appendix 7).

\section{Kentucky Coking Coal Sample}

One sample of coking coal from the Middle Pennsylvanian (Atokan) Upper Elkhorn No. 1 coal bed in the Pikeville Formation at the Frasier Branch Mine near the town of Grethel in Floyd County, Kentucky, was provided by Cortland Eble and James Hower (appendix 2).

The Upper Elkhorn No. 1 sample was a high-volatile A bituminous coal (based on VM [dmmf] and CV [mmmf]) (appendix 3). Ash yield in the Kentucky sample was 4.30 percent (dry), and sulfur content was 0.81 percent (appendix 3).

Major element analyses for the Upper Elkhorn No. 1 sample are presented in appendix 4 . The major element oxide percentages generally fall within the normal ranges for typical bituminous ash yields in the United States (appendix 4) (Riley, 2007). $\mathrm{P}_{2} \mathrm{O}_{5}$ content in the ash of the Upper Elkhorn No. 1 sample was 0.12 percent (appendix 4). 
The Upper Elkhorn No. 1 coal sample had a pCSR value of 47.51 (appendix 4).

The FSI value for the Upper Elkhorn No. 1 sample was 5 (appendix 6), indicating poor coking potential (Zimmerman, 1979). The Upper Elkhorn No. 1 sample had a Gieseler maximum fluidity of $515 \mathrm{ddpm}$ and a plastic range of $65^{\circ} \mathrm{C}$ (appendix 6). The Upper Elkhorn No. 1 sample's dilatation was 41 percent (appendix 6).

Mean $\mathrm{R}_{\mathrm{o}} \max$ for the Upper Elkhorn No. 1 sample was 0.79 percent (appendix 7), which places it in the high-volatile B bituminous rank (Davis, 1978).

The Upper Elkhorn No. 1 sample had a pCSF value of 32 (appendix 7).

\section{Pennsylvania data from an anonymous company}

Data representing 13 samples in Pennsylvania were provided by an anonymous mining company in Pennsylvania. At the request of the company we have only identified the sample locations by the coal bed and county from which they originated. All 13 samples came from the Middle Pennsylvanian (Desmoinesian) Allegheny Group. Five samples came from Indiana County, Pennsylvania, from the Upper Freeport, Upper Kittanning, Middle Kittanning, Lower Kittanning, and Brookville coal beds (appendix 2). Three samples came from Somerset County, Pennsylvania, from the Upper Freeport, Upper Kittanning, and Lower Kittanning coal beds. One sample was from Elk County, Pennsylvania, from the Lower Kittanning coal bed. Three samples came from Cambria County, Pennsylvania, from the Upper Freeport, Lower Freeport, and Upper Kittanning coal beds. The final sample came from Clearfield County, Pennsylvania, from the Upper Kittanning coal bed. Twelve of the samples were composed of washed 1.40 specific gravity float material, and the remaining sample, from the Upper Kittanning coal bed in Indiana County, was clean coal.

Coal rank of the Pennsylvania samples ranged from high-volatile A bituminous (the Upper Freeport and Upper Kittanning samples in Indiana and Elk Counties) through medium-volatile bituminous (the Middle and Lower Kittanning and Brookville samples from Indiana County, the Lower Freeport sample in Cambria County, and the Upper Kittanning sample in Clearfield County) to low-volatile bituminous (all three Somerset County samples, and the Upper Freeport and Upper Kittanning samples from Cambria County) (ranks based on VM [dmmf] and CV [mmmf] values) (appendix 3). Ash yield in the Pennsylvania samples ranged from 4.91 percent (dry) to 9.62 percent (dry) (appendix 3). No ash yield was provided for the Upper Kittanning sample from Somerset County. Sulfur content ranged from 0.6 percent (daf) to 1.62 percent (daf) (appendix 3). No sulfur content was provided for the Upper Kittanning sample from Somerset County.

Major element oxide percentages for the Pennsylvania samples were mostly within the normal ranges for typical bituminous ash samples in the United States (appendix
4) (Riley, 2007), except for the $\mathrm{Fe}_{2} \mathrm{O}_{3}$ percentages from the Upper Freeport, Middle Kittanning, and Brookville samples from Indiana County, which all fell below the normal range (less than 5 percent) (appendix 4). $\mathrm{P}_{2} \mathrm{O}_{5}$ contents in the ash of the Pennsylvania samples ranged from 0.16 percent to 1.19 percent (appendix 4).

We were able to calculate pCSR values for 12 of the 13 Pennsylvania samples and they ranged from 25.4 to 74.7 (appendix 4).

FSI values for the Pennsylvania samples ranged from 6 (poor coking ability [Zimmerman, 1979]) through 9 (excellent coking ability) (appendix 6). The Pennsylvania samples had Gieseler maximum fluidity values ranging from 2 to 29,689 ddpm, Gieseler plastic range values from 30 to $114{ }^{\circ} \mathrm{C}$, and dilatation values from -24 to 300 (appendix 6).

Mean $\mathrm{R}_{\mathrm{o}}$ max values for the Pennsylvania samples ranged from 0.95 to 1.76 (appendix 7), placing these samples into the low-, medium-, and high-volatile A bituminous ranks (based on mean $\mathrm{R}_{\mathrm{o}} \max$ [Davis, 1978]).

Oxidation, HGI, and ash fusion (in a reducing environment) initial deformation temperature (Ash Fusion IT), softening temperature (Ash Fusion ST), hemispherical temperature (Ash Fusion HT), and fluid temperature (Ash Fusion FT) test data were also provided for the Pennsylvania samples (appendix 8).

Values for $\mathrm{pCSF}$ for the Pennsylvania samples ranged from 34 to 65 (appendix 7).

\section{West Virginia data from ArcelorMittal}

Data representing 40 samples in West Virginia were provided by Richard Kruse of ArcelorMittal USA (appendix 2 ). At the request of ArcelorMittal, we have only identified the sample locations by the county from which they originated. All 40 samples came from the Lower Pennsylvanian (Morrowan) New River Formation at an unspecified coal mine in McDowell County, West Virginia. Eight coal beds were sampled, each with five samples collected on different dates in 2014 or 2015. The following coal beds were sampled (in ascending stratigraphic order): Pocahontas No. 9, Lower Horsepen, Fire Creek(?), Beckley(?) lower split, Beckley(?) upper split, Little Raleigh(?) lower split, Little Raleigh(?) upper split, and Welch(?). As per Richard Kruse, the identification of most of these beds (those marked with question marks) was not entirely certain because the miners used the names Bed 10, Bed 11A, Bed 11B, Bed 12A, Bed 12B, and Bed $12 \mathrm{C}$ for the beds above the Lower Horsepen. Only the Pocahontas No. 9 (Bed 9) and Lower Horsepen (LHP) beds can be positively identified.

The ArcelorMittal samples were all low-volatile bituminous rank (based on VM [dmmf] values) (appendix 3). Sample Bed 11A-3 from the Beckley(?) upper split had a CV of only $13,655 \mathrm{Btu} / \mathrm{lb}(\mathrm{mmmf})$, which is in the range expected for high-volatile B bituminous coals (appendix 3). Despite the low CV (which may have been due to an unusually high ash yield), 
we classified this sample as a low-volatile bituminous coal like the other samples from this bed, and the other beds in this mine. Ash yield in the ArcelorMittal samples ranged from 1.65 to 11.4 percent (dry) (appendix 3). Sulfur content ranged from 0.51 to 1.63 percent (daf) (appendix 3).

Major element oxide percentages for the ArcelorMittal samples were for the most part within the normal ranges for typical bituminous ash samples in the United States (appendix 4) (Riley, 2007) except for low $\mathrm{CaO}$ values (less than 1 percent) in 15 samples, low $\mathrm{Fe}_{2} \mathrm{O}_{3}$ values (less than 5 percent) in four samples, high $\mathrm{K}_{2} \mathrm{O}+\mathrm{Na}_{2} \mathrm{O}$ values (greater than 4 percent) in 10 samples, and high $\mathrm{SiO}_{2}$ values (greater than 60 percent) in 2 samples (appendix 4). The percentages of $\mathrm{P}_{2} \mathrm{O}_{5}$ in the ash in the ArcelorMittal samples ranged from 0.00 to 1.14 percent (appendix 4).

FSI values for the ArcelorMittal samples ranged from 5 to 9 , with only 3 samples having values less than 7 (poor coking ability [Zimmerman, 1979]), and 32 samples having values greater than or equal to 8 (good to excellent coking ability) (appendix 6). The ArcelorMittal samples had Gieseler maximum fluidity values ranging from 2 to $1,694 \mathrm{ddpm}$ (appendix 6). Gieseler plastic range values ranged from 40 to $93{ }^{\circ} \mathrm{C}$ (appendix 6). Dilatation values ranged from 7 to 170 percent (appendix 6).

Mean $\mathrm{R}_{0}$ max values for the ArcelorMittal samples ranged from 1.42 to 1.6, placing the samples in the low- to mediumvolatile bituminous ranks (based on mean $\mathrm{R}_{0} \max$ [Davis, 1978]) (appendix 7).

The ArcelorMittal samples had pCSR values ranging from 26.3 to 69 (appendix 4).

Oxidation, HGI, and ash fusion (in a reducing environment) initial deformation temperature (Ash Fusion IT), softening temperature (Ash Fusion ST), hemispherical temperature (Ash Fusion HT), and fluid temperature (Ash Fusion FT) test data were also provided for the ArcelorMittal samples (appendix 8).

\section{West Virginia, Virginia, and Kentucky data from Corky's Carbon Consultancy}

Data representing 15 samples from West Virginia, five from Virginia, and two from Kentucky were provided by David Cork of Corky's Carbon Consultancy (appendix 2). At the request of Corky's Carbon Consultancy, we have only identified the sample locations by the county from which they originated. These samples were collected in 2010 from multiple mines.

Seven of the West Virginia samples came from the Middle Pennsylvanian (Atokan) Kanawha Formation at unspecified coal mines in Boone, Logan, Mingo, Nicholas, and Raleigh Counties, West Virginia. Six coal beds were sampled in these five counties including the Peerless bed (in Boone and Raleigh Counties), the Powellton bed (in Boone County), the Alma and Cedar Grove beds (in Logan County), the No. 2
Gas bed (in Mingo County), and the Eagle bed (in Nicholas County). Another West Virginia sample (WVRaleigh1) came from the Lower Pennsylvanian (Morrowan) Beckley coal bed in the New River Formation at an unspecified coal mine in Raleigh County, West Virginia. The Beckley coal bed sample was listed as a blend of several coals. The seven remaining West Virginia samples had unspecified formation and bed names; two came from Boone County, and one each came from Kanawha, Logan, Nicholas, Raleigh, and Wyoming Counties. The Kanawha County sample was listed as a blend of several coals, and the Boone County sample was listed as a high-ash metallurgical coal.

Data from five more Corky's Carbon Consultancy samples (hereafter shortened to Corky's samples) came from unspecified mines in Virginia, one from Tazewell County, and the other four from Wise County. The Tazewell County sample came from the Lower Pennsylvanian (Morrowan) Tiller coal bed in the New River Formation. One of the Wise County samples came from the Lower Pennsylvanian (Morrowan) Kennedy coal bed in the New River Formation. The other three Wise County samples had unspecified formation and bed names. One of these three samples was listed as a blend of coals.

Finally, data from two more Corky's samples came from unspecified mines in Owsley and Pike Counties, Kentucky. The Pike County sample was from the Middle Pennsylvanian (Atokan) Alma coal bed in the Pikeville Formation. The Owsley sample had unspecified bed and formation names.

Most of the Corky's samples were high-volatile A bituminous coals (based on VM [dmmf] and CV [mmmf]), with the exception of three, which were low-volatile bituminous (WVWyoming) and medium-volatile bituminous (WVNicholas1 and VAWise3) (appendix 3). Ash yield in the Corky's samples ranged from 5.00 to 13.33 percent (dry) (appendix 3). Sulfur content in the Corky's samples ranged from 0.51 to 2.27 percent (daf) (appendix 3).

Major element oxide percentages for the Corky's samples are for the most part within the normal ranges for typical bituminous ash samples in the United States (appendix 4) (Riley, 2007), except for low $\mathrm{CaO}$ values (less than 1 percent) in three samples, low $\mathrm{Fe}_{2} \mathrm{O}_{3}$ values (less than 5 percent) in five samples, high $\mathrm{K}_{2} \mathrm{O}+\mathrm{Na}_{2} \mathrm{O}$ values (greater than 4 percent) in one sample, and high $\mathrm{SiO}_{2}$ values (greater than 60 percent) in one sample (appendix 4). Acid to base ratios in the Corky's samples ranged from 2.8 to 21.8 (appendix 4). The percentages of $\mathrm{P}_{2} \mathrm{O}_{5}$ in the ash in the Corky's samples ranged from 0.03 to 1.18 percent (appendix 4 ).

We calculated pCSR values for all but one of the Corky's West Virginia coal samples (appendix 4). The pCSR values ranged from 43.9 to 71.3 .

FSI values for the Corky's samples ranged from 6 to 8.5 , with only two samples having values less than seven (poor to marginal coking ability; Zimmerman, 1979), and eight having values greater than or equal to eight (good to excellent coking ability) (appendix 6). The Corky's samples had Gieseler 
maximum fluidity values ranging from 67 to 30,000 ddpm (appendix 6). Gieseler plastic range values ranged from 61 to $114{ }^{\circ} \mathrm{C}$ (appendix 6). Dilatation values ranged from 34 to 300 (appendix 6).

Mean $\mathrm{R}_{\mathrm{o}}$ max values for the Corky's samples ranged from 0.89 to 1.59 (appendix 7) placing these samples in the high-volatile B, medium- and low-volatile bituminous ranks (Davis, 1978).

Oxidation, HGI, and ash fusion (in a reducing environment) initial deformation temperature (Ash Fusion IT), softening temperature (Ash Fusion ST), hemispherical temperature (Ash Fusion HT), and fluid temperature (Ash Fusion FT) test data were also provided for some of the Corky's samples (appendix 8).

We calculated pCSF values for all but two of the Corky's coal samples (appendix 7). The pCSF values ranged from 30 to 62.1 .

\section{Conclusions}

Coking coal, or metallurgical coal, is primarily used in the production of coke for use in the steel industry. Coke is made by heating metallurgical coal to temperatures of 1,000 to $1,100{ }^{\circ} \mathrm{C}$ in a low-oxygen environment for 12 to 36 hours (Holway, 1975; World Coal Association, 2018). The coal liquefies and its volatile matter (VM) is released before it hardens into a hard, porous solid that is high in carbon and low in ash, sulfur, and phosphorus. Coke provides heat to melt iron ore, carbon to make carbon monoxide that reduces iron ore to metallic iron, and structural support for the "charge" (iron ore, limestone, and coal) in a blast furnace (Holway, 1975). Porosity in the coke allows hot air and carbon monoxide to pass evenly through the blast furnace (Holway, 1975). Limestone removes sulfur from the steel. (Holway, 1975). Today, most coke is made in large by-product coke ovens or modern heat-recovery (or non-recovery) ovens, but in the early days of the industry it was made in smaller beehive ovens.

Numerous chemical, rheological, petrographic, and other analyses are performed on coals to determine if they are satisfactory for making coke. Percentages of VM, ash, sulfur, $\mathrm{P}_{2} \mathrm{O}_{5}$ in the ash, and the acid-to-base ratio in ash are useful chemical properties for evaluating the coking potential of coals. In general, "low" values for $\mathrm{VM}$, ash, sulfur, and $\mathrm{P}_{2} \mathrm{O}_{5}$ in the ash, and "high" acid-to-base ratio values in washed U.S. bituminous coals are considered beneficial for coke-making potential, but the ranges of acceptable "low" and "high" values vary for different ranks of coal (tables 1 to 3). "High" values for Free Swelling Index (FSI), maximum fluidity and plastic range (from the Gieseler Plastometer test), and dilatation (from the ASTM dilatation test) in washed U.S. bituminous coals indicate good coking potential. Among the petrographic tests, "high" $\mathrm{R}_{\mathrm{o}}$ max values and "medium" percentages of total inert components in washed U.S. bituminous coals are considered desirable for good coking potential. And finally, "high" light transmittance percentages (from the alkali-extraction [oxidation] test), Hardgrove Grindability Index (HGI) values, and ash-fusion (in a reducing environment) softening temperatures (ST) in washed U.S. bituminous coals are considered beneficial for coking potential. Often a coal may have an acceptable value for one test, and an unacceptable value for another test. For this reason, different coals are blended to create an endproduct that has acceptable values for coking potential using multiple tests. It is rare for a single coal to meet all criteria for a satisfactory coking coal by itself.

New coking coal samples from Alabama, Kentucky, Oklahoma, and Arkansas were collected and analyzed for chemical, rheological, petrographic, and other properties. Results of these new analyses are included in the report. Additional data for samples from Pennsylvania, West Virginia, Virginia, and Kentucky provided by three companies are also included in the report.

Coals from western U.S. States (Arkansas, Oklahoma, New Mexico, Colorado, Utah, Wyoming, Montana, Washington, and Alaska) have had mining for coking coal in the past, but only Arkansas coking coals are currently mined. Production of Illinois coking coal is currently declining, and Indiana coals are only used for pulverized coal injection (PCI) in steel mills (Valia and Mastalerz, 2004). Today, most U.S. coking coal is produced in the Appalachian basin in Alabama, Pennsylvania, West Virginia, and Virginia. Kentucky, Georgia, Maryland, Ohio, and Tennessee also produced coking coal in the past, but do not today.

GIS files representing the locations of coking coal deposits and mines of historical importance in the western United States are available for download. These GIS data and the analytical data included in this report may be useful to researchers who wish to make maps displaying the coking coal resources of the United States. Data in appendixes 2 to 8, 20, and 21 can also be downloaded from https://doi.org/10.5066/ P9KFQOKM.

\section{References Cited}

Alabama Department of Labor Office of Mine Safety and Inspection, 2017, Quarterly fiscal year 2017 coal reports: 7 p. [first quarter, fiscal year 2016; Oct., Nov., Dec., 2016], accessed June 10, 2019, at https://labor.alabama.gov/ inspections/mining/docs/MR_1st_QTR_2017.pdf; 7 p. [second quarter, fiscal year 2017; Jan., Feb., Mar., 2017], accessed June 10, 2019, at https://labor.alabama.gov/ inspections/mining/docs/MR_2nd_QTR_2017.pdf; 7 p. [third quarter, fiscal year 2017; Apr., May, June, 2017], accessed June 10, 2019, at https://labor.alabama.gov/ inspections/mining/docs/MR_3rd_QTR_2017.pdf; 7 p. [fourth quarter, fiscal year 2017; July, Aug., Sept., 2017], accessed June 10, 2019, at https://labor.alabama.gov/ inspections/mining/docs/MR_4th_QTR_2017.pdf. 
Alaska Division of Geological \& Geophysical Surveys (ADGGS), 1990, Alaska's high-rank coals: Information Circular 33, 36 p., accessed March 9, 2018, at http://www.dggs.dnr.state.ak.us/pubs/id/480.

Allen, J.H., 1888, Western Kentucky coals and cokes: Transactions of the American Institute of Mining Engineers, v. 16, p. 581-593.

Alpha Natural Resources, 2016, Company Overview, November 2016: 28 p., accessed October 25, 2017, at http://www.alphanr.com/Documents/Alpha\%20Natural\%20 Resources\%20Company\%20Overview\%20Old.pdf.

American Coke and Coal Chemicals Institute, 2018, [Operating U.S. coke plants list] U.S. and Canadian coke plants: 1 p., accessed December 21, 2018, at http://www.accci.org/industry.html.

Andrews, R.D., Cardott, B.J., and Storm, T., 1998, The Hartshorne play in southeastern Oklahoma-Regional and detailed sandstone reservoir analysis and coalbed-methane resources: Oklahoma Geological Survey Special Publication 98-7, 90 p. [Also available at http://ogs.ou.edu/docs/ specialpublications/SP98-7.pdf.]

Andrews, R.J., Rantell, T., Jacques, D., Hower, J.C., Gardner, J.S., and Amick, M., 2010, Mild coal extraction for the production of anode coke from Blue Gem coal: Fuel, v. 89, no. 9, p. 2640-2647. [Also available at https://doi.org/ 10.1016/j.fuel.2010.04.027.]

Arch Coal, 2019, West Elk Mine: Arch Coal Inc. web page, accessed April 22, 2019, at http://www.archcoal.com/ aboutus/westelk.aspx.

Author unknown, 1932, Stratigraphical measure thru portion of Roslyn coal measures: Washington State Coal Mine Map Collection, Publication KT1-I1, publisher unknown, accessed on March 21, 2014, at https://fortress.wa.gov/dnr/ geology/?Theme=coalmine.

Averitt, P., 1966, Coking-coal deposits of the western United States: U.S. Geological Survey Bulletin 1222-G, 48 p., accessed October 26, 2016, at https://pubs.usgs.gov/bul/ $1222 \mathrm{~g} /$ report.pdf.

Barlow, J.A., 1974, Coal and coal mining in West Virginia: West Virginia Geological and Economic Survey, CoalGeology Bulletin No. 2, 63 p.

Barnes, F.F., 1951, A review of the geology and coal resources of the Bering River coal field, Alaska: U.S. Geological Survey Circular 146, 11 p., accessed October 26, 2016, at https://pubs.usgs.gov/circ/1951/0146/report.pdf.
Barnes, F.F., and Ford, D.M., 1952, Coal prospects and coal exploration and development in the Lower Matanuska Valley, Alaska: U.S. Geological Survey Circular 154, 5 p., 1 pl., accessed October 26, 2016, at https://pubs.usgs.gov/ circ/1952/0154/report.pdf.

Beaumont, E.C., 1979, Geology of the Cerrillos coal field, Santa Fe County, New Mexico, in Ingersoll, R.V., Woodward, L.A., and James, H.L., eds., Santa Fe country: New Mexico Geological Society 30th Annual Fall Field Conference Guidebook, 310 p., accessed November 4, 2016, at https://nmgs.nmt.edu/publications/ guidebooks/downloads/30/30_p0269_p0274.pdf.

Beikman, H.M., Gower, H.D., and Dana, T.A.M., 1961, Coal reserves of Washington: Washington Department of Conservation, Division of Mines and Geology, Bulletin 47, 115 p., accessed July 25, 2019, at ftp://ww4.dnr.wa.gov/ geology/data_downloads/bulletins/ger_b47_coal_ reserves_wa.pdf.

Berryhill, L.R., Brown, D.M., Brown, A., and Taylor, D.A., 1950, Coal resources of Wyoming: U.S. Geological Survey Circular 81, 78 p. [Also available at https://doi.org/ 10.3133/cir81.]

Berryhill, L.R., and Averitt, P., 1951, Coking-coal deposits of the western United States: U.S. Geological Survey Circular 90, 20 p., accessed August 19, 2019, at https://pubs.usgs.gov/circ/1951/0090/report.pdf.

Black Range Minerals, 2015, Jonesville Coal Project: accessed October 26, 2016, at http://www.blackrangeminerals.com/ content/projects/jonesville-coal-project/.

Blake, B.M., 1992, Stratigraphy of the Lower and Middle Pennsylvanian Series in West Virginia, in Cecil, C.B., and Eble, C.F., eds., Paleoclimate controls on Carboniferous sedimentation and cyclic stratigraphy in the Appalachian basin: U.S. Geological Survey Open-File Report 92-546, p. 102-114. [Also available at https://pubs.er.usgs.gov/publication/ofr92546.]

Blake, B.M., Jr., 1998, Regional stratigraphy and coal geology of the middle part of the Kanawha Formation in southern West Virginia, in Martino, R.L., Blake, B.M., Jr., Grady, W.C., and Eble, C.F., ed., Coal geology, paleobotany, and regional stratigraphy of the middle part of the Kanawha Formation, southern West Virginia: Southeast Section, Geological Society of America, Coal Division Field Trip, Charleston, W. Va., March 28-29, 1998, p. 1-15. 
Blake, B.M., Jr., Keiser, A.F., and Rice, C.L., 1994, Revised stratigraphy and nomenclature for the Middle Pennsylvanian Kanawha Formation in southwestern West Virginia, in Rice, C.L., ed., Elements of Pennsylvanian stratigraphy, central Appalachian basin: Boulder, Colo., Geological Society of America Special Paper 204, p. 41-54.

Blaylock, D.W., Dowd, J.J., Abernethy, R.F., and Reynolds, D.A., 1955, Estimate of known recoverable reserves of coking coal in Clearfield County, Pa.: U.S. Bureau of Mines Report of Investigations 5166, 36 p.

Blaylock, D.W., Dowd, J.J., Abernethy, R.F., and Reynolds, D.A., 1956, Estimate of known recoverable reserves of coking coal in Clarion County, Pa.: U.S. Bureau of Mines Report of Investigations 5231, 27 p.

Bownocker, J.A., and Dean, E.S., 1929, Analyses of the coals of Ohio: Geological Survey of Ohio Bulletin 34, Fourth Series, 360 p. [Also available at https://kb.osu.edu/handle/ 1811/78507.]

Bownocker, J.A., Lord, N.W., and Somermeier, E.E., 1908, Coal-Part one, coals of the Monongahela Formation or upper productive coal measures; Part two-Chemical analyses and calorific tests of the Clarion, Lower Kittanning, Middle Kittanning and Upper Freeport coals: Geological Survey of Ohio Bulletin 9, Fourth Series, 388 p.

Bradbury, T., 2014, Independent technical and geological summary report-Assets of Texas and Oklahoma Coal Company Metals Finance Limited: GEOS Mining Minerals Consultants, [Report for] Job No. 2600-01, 173 p., accessed November 7, 2016, at http:/www.pamcoal.com/ Assets/Documents/2600-01_TOCC $\% 20$ Assets $\% 20$ Independent $\% 20$ Review.pdf.

Brooks, A.H., 1905, Report on progress of investigations of mineral resources of Alaska in 1904: U.S. Geological Survey Bulletin 259, Series A, Economic Geology, no. 52, 196 p., accessed October 26, 2016, at https://pubs.er.usgs.gov/publication/b259.

Buch, J.W., De Carlo, J.A., and Otero, M.M., 1943, Coke and byproducts - Chapter preprint from Minerals Yearbook 1942: U.S. Bureau of Mines, 53 p.

Calvert, W.R., 1909, Geology of the Lewistown coal field, Montana: U.S. Geological Survey Bulletin 390, 83 p., accessed October 26, 2016, at https://pubs.usgs.gov/bul/ 0390/report.pdf.

Calvert, W.R., 1912a, The Electric coal field, Park County, Montana, in Campbell, M.R. ed., Contributions to economic geology 1910 (short papers and preliminary reports)_Part II, mineral fuels: U.S. Geological Survey Bulletin 471, p. 406-422, accessed October 26, 2016, at https://pubs.usgs.gov/bul/0471e/report.pdf.
Calvert, W.R., 1912b, The Livingston and Trail Creek coal fields, Park, Gallatin, and Sweetgrass Counties, Montana, in Campbell, M.R. ed., Contributions to economic geology 1910 (short papers and preliminary reports)_Part II, mineral fuels: U.S. Geological Survey Bulletin 471, p. 384-405, accessed October 26, 2016, at https://pubs.usgs.gov/bul/ 0471e/report.pdf.

Carbon Hill Coal Company, 1916, Map of the WilkesonCarbonado coal field: Washington State Coal Mine Map Collection, Publication P21-C, 1 sheet, scale 1:4,800, accessed March 21, 2014, at https://fortress.wa.gov/dnr/ geology/?Theme $=$ coalmine.

Cardott, B.J., 2013, Hartshorne coal rank applied to Arkoma Basin coalbed methane activity, Oklahoma, USA: International Journal of Coal Geology, v. 108, p. 35-46. [Also available at https://doi.org/10.1016/j.coal.2011.07.002.]

Carroll, C.J., 2006, Coal resource maps of Colorado: Colorado Geological Survey, MS-43, 3 pls., scale 1:500,000, accessed August 21, 2019, at https://store.coloradogeologicalsurvey.org/ product/coal-resource-maps-colorado/.

Carroll, C.J., 2011, 2011 Colorado coal fact sheet: Colorado Geological Survey, 2 p. [Also available at http://coloradogeologicalsurvey.org/wp-content/uploads/ 2013/08/2011-Coal-fact-sheet-combined.pdf.]

Chandler, A., 2013, Mining, minerals and more in the western Ouachita Mountains: Educational Workshop Series 06, Arkansas Geological Survey, 23 p., accessed November 7, 2016, at https://www.geology.arkansas.gov/docs/pdf/ publication/educational-workshops/EWS-06.pdf.

Cokedale Coal Company, [publication date unknown], Cokedale Coal Company plan and profile of Klondyke seams: Washington State Coal Mine Map Collection, Publication S1_A, accessed March 21, 2014, at https://fortress.wa.gov/dnr/geology/?Theme=coalmine.

Coleman, S.L., Crawford, T.J., and Medlin, J.H., 1985, Quality of coal resources underlying Sand and Lookout Mountains, Georgia and Alabama: Georgia Geologic Survey Bulletin 102,75 p.

Combo, J.X., Brown, D.M., Pulver, H.F., and Taylor, D.A., 1949, Coal resources of Montana: U.S. Geological Survey Circular 53, 30 p., accessed October 26, 2016, at https://pubs.usgs.gov/circ/1949/0053/report.pdf.

Cooper, F.D., 1975, Coke and coal chemicals, in Metals, minerals, and fuels-Minerals Yearbook 1974: U.S. Bureau of Mines, v. 1, p. 441-478.

Cooper, F.D., 1976, Coke and coal chemicals, in Metals, minerals, and fuels-Minerals Yearbook 1975: U.S. Bureau of Mines, v. 1, p. 497-544. 
Coppock, M., 2015, Coal industry muted, but still alive in Oklahoma: GateHouse Media web page [online article published March 4, 2015], accessed November 4, 2016, at http://newsok.com/article/5398246.

Coulter, D.M., 1947, Coking coal deposits on Lookout Mountain, Dekalb and Cherokee Counties, Alabama: U.S. Bureau of Mines, Report of Investigations 4030, 89 p.

Craddock, J.D., Rantell, T.D., Hower, J.C., Whitlow, D.T., Wiseman, J., and Weisenberger, M.C., 2017, Anode coke from coal-A low cost approach: Fuel, v. 187, p. 229-241. [Also available at https://doi.org/10.1016/ j.fuel.2016.09.045.]

Culbertson, W.C., 1964, Geology and coal resources of the coal-bearing rocks of Alabama: U.S. Geological Survey Bulletin 1182-B, 79 p., 4 pls. [Also available at https://doi.org/10.3133/b1182B.]

Daniels, J., 1979, Mining history of Pierce County, Washington coal fields, 1860-1962: Washington Division of Geology and Earth Resources, Open-File Report OF 79-1, 161 p. [Also available at https://www.dnr.wa.gov/ Publications/ger_ofr79-1_mining_history_pierce_co.pdf.]

Darton, N.H., 1905, The Coal of the Black Hills, Wyoming, in Emmons, S.F., and Eckel, E.C., eds., Contributions to economic geology, 2004: U.S. Geological Survey Bulletin 260, Series A, Economic Geology, 53 p.

Davis, A., 1978, The reflectance of coal, chap. 2 of Karr, C., Jr., ed., Analytical methods for coal and coal products: New York, Academy Press, v. 1, p. 27-81. [Also available at https://doi.org/10.1016/B978-0-12-399901-6.50008-6.]

Davis, J.D., and Reynolds, D.A., 1941, Carbonizing properties of Henryetta bed coal from Atlas No. 2 Mine, Henryetta, Okmulgee County, Oklahoma: Oklahoma Geological Survey Mineral Report 12, 12 p.

Davis, J.D., and Reynolds, D.A., 1942, Carbonizing properties of McAlester bed coal from Dow No. 10 Mine, Dow, Pittsburg County, Oklahoma (preliminary report): Oklahoma Geological Survey Mineral Report 15, 15 p.

De Carlo, J.A., Otero, M.M., and Buch, J.W., 1945, Coke and byproducts, in Needham, C.E., ed., Minerals yearbook 1943: U.S. Bureau of Mines, p. 982-1039. [Also available at https://www.usgs.gov/centers/nmic/bureau-minesminerals-yearbook-1932-1993.]

De Carlo, J.A., Corgan, J.A., and Otero, M.M., 1946, Coke and byproducts, in Needham, C.E., ed., Minerals Yearbook 1944: U.S. Bureau of Mines, p. 946-1002. [Also available at https://www.usgs.gov/centers/nmic/bureau-minesminerals-yearbook-1932-1993.]
De Carlo, J.A., Corgan, J.A., and Otero, M.M., 1947, Coke and byproducts, in Keiser, H.D., ed., Minerals yearbook 1945: U.S. Bureau of Mines, p. 958-1016. [Also available at https://www.usgs.gov/centers/nmic/bureau-minesminerals-yearbook-1932-1993.]

De Carlo, J.A., Corgan, J.A., and Otero, M.M., 1948, Coke and coal chemicals, in Mathews, A.F., ed., Minerals Yearbook 1946: U.S. Bureau of Mines, p. 400-456. [Also available at https://www.usgs.gov/centers/nmic/bureaumines-minerals-yearbook-1932-1993.]

De Carlo, J.A., Corgan, J.A., and Otero, M.M., 1949, Coke and coal chemicals, in Mathews, A.F., ed., Minerals Yearbook 1947: U.S. Bureau of Mines, p. 389-448. [Also available at https://www.usgs.gov/centers/nmic/bureaumines-minerals-yearbook-1932-1993.]

De Carlo, J.A., Corgan, J.A., and Otero, M.M., 1950, Coke and coal chemicals, in Mathews, A.F., ed., Minerals Yearbook 1948: U.S. Bureau of Mines, p. 409-472. [Also available at https://www.usgs.gov/centers/nmic/bureaumines-minerals-yearbook-1932-1993.]

De Carlo, J.A., Corgan, J.A., and Otero, M.M., 1951, Coke and coal chemicals, in Mathews, A.F., ed., Minerals yearbook 1949: U.S. Bureau of Mines, p. 399-458. [Also available at https://www.usgs.gov/centers/nmic/bureau-minesminerals-yearbook-1932-1993.]

De Carlo, J.A., Corgan, J.A., and Otero, M.M., 1953, Coke and coal chemicals, in Leonard, L., ed., Minerals yearbook 1950: U.S. Bureau of Mines, p. 403-464. [Also available at https://www.usgs.gov/centers/nmic/bureau-mines-mineralsyearbook-1932-1993.]

De Carlo, J.A., Corgan, J.A., and Otero, M.M., 1954, Coke and coal chemicals, in McGann, P.W., ed., Minerals yearbook 1951: U.S. Bureau of Mines, p. 459-520. [Also available at https://www.usgs.gov/centers/nmic/bureau-minesminerals-yearbook-1932-1993.]

De Carlo, J.A., Corgan, J.A., and Otero, M.M., 1955, Coke and coal chemicals, in Minerals yearbookFuels 1952: U.S. Bureau of Mines, p. 181-244. [Also available at http://digital.library.wisc.edu/1711.dl/ EcoNatRes.MinYB1952v2.]

De Carlo, J.A., Corgan, J.A., and Otero, M.M., 1956, Coke and coal chemicals, in Minerals yearbook-Fuels 1953: U.S. Bureau of Mines, v. 2, p. 213-274. [Also available at http://digital.library.wisc.edu/1711.dl/ EcoNatRes.MinYB1953v2.] 
De Carlo, J.A., Hunter, T.W., and Otero, M.M., 1958a, Coke and coal chemicals, in Minerals yearbook 1954Fuels: U.S. Bureau of Mines, v. 2, p. 181-243. [Also available at http://digital.library.wisc.edu/1711.dl/ EcoNatRes.MinYB1954v2.]

De Carlo, J.A., Hunter, T.W., and Otero, M.M., 1958b, Coke and coal chemicals, in Minerals yearbook 1955Fuels: U.S. Bureau of Mines, v. 2, p. 167-233. [Also available at http://digital.library.wisc.edu/1711.dl/ EcoNatRes.MinYB1955v2.]

De Carlo, J.A., Hunter, T.W., and Otero, M.M., 1958c, Coke and coal chemicals, in Minerals yearbook 1956Fuels: U.S. Bureau of Mines, v. 2, p. 167-227. [Also available at http://digital.library.wisc.edu/1711.dl/ EcoNatRes.MinYB1956v2.]

De Carlo, J.A., Hunter, T.W., and Otero, M.M., 1959a, Coke and coal chemicals, in Minerals yearbook 1957Fuels: U.S. Bureau of Mines, v. 2, p. 191-251. [Also available at http://digital.library.wisc.edu/1711.dl/ EcoNatRes.MinYB1957v2.]

De Carlo, J.A., Hunter, T.W., and Otero, M.M., 1959b, Coke and coal chemicals, in Minerals yearbook 1958Fuels: U.S. Bureau of Mines, v. 2, p. 197-262. [Also available at http://digital.library.wisc.edu/1711.dl/ EcoNatRes.MinYB1958v2.]

De Carlo, J.A., Hunter, T.W., and Otero, M.M., 1960, Coke and coal chemicals, in Minerals yearbook 1959Fuels: U.S. Bureau of Mines, v. 2, p. 187-247. [Also available at http://digital.library.wisc.edu/1711.dl/ EcoNatRes.MinYB1959v2.]

De Carlo, J.A., Hunter, T.W., and Otero, M.M., 1961, Coke and coal chemicals, in Minerals yearbook 1960Fuels: U.S. Bureau of Mines, v. 2, p. 205-268. [Also available at http://digital.library.wisc.edu/1711.dl/ EcoNatRes.MinYB1960v2.]

De Carlo, J.A., Hunter, T.W., and Otero, M.M., 1962, Coke and coal chemicals, in Minerals yearbook 1961Fuels: U.S. Bureau of Mines, v. 2, p. 203-263. [Also available at http://digital.library.wisc.edu/1711.dl/ EcoNatRes.MinYB1961v2.]

De Carlo, J.A., Sheridan, E.T., and Otero, M.M., 1963, Coke and coal chemicals, in Minerals yearbook 1962Fuels: U.S. Bureau of Mines, v. 2, p. 211-271. [Also available at http://digital.library.wisc.edu/1711.dl/ EcoNatRes.MinYB1962v2.]

De Carlo, J.A., and Sheridan, E.T., 1964, Coke and coal chemicals, in Minerals yearbook 1963-Mineral fuels: U.S. Bureau of Mines, v. 2, p. 225-287. [Also available at http://digital.library.wisc.edu/1711.dl/ EcoNatRes.MinYB1963v2.]
De Carlo, J.A., and Sheridan, E.T., 1965, Coke and coal chemicals, in Minerals yearbook 1964-Mineral fuels: U.S. Bureau of Mines, v. 2, p. 209-270. [Also available at http://digital.library.wisc.edu/1711.dl/ EcoNatRes.MinYB1964v2.]

De Carlo, J.A., and Sheridan, E.T., 1967, Coke and coal chemicals, in Minerals Yearbook 1965-Mineral fuels: U.S. Bureau of Mines, v. 2, p. 199-250. [Also available at http://digital.library.wisc.edu/1711.dl/ EcoNatRes.MinYB1965v2.]

De Carlo, J.A., and Watson, B.D., 1968, Coke and coal chemicals, in Minerals Yearbook 1967-Metals, minerals, and fuels: U.S. Bureau of Mines, v. 1-2, p. 387-430. [Also available at http://digital.library.wisc.edu/1711.dl/ EcoNatRes.MinYB1967v1and2.]

DeVanney, K.F., and Mitchell, G.D., 2015, Metallurgical Coal and Coke Seminar; 2-Day Course Class Book: Murrysville, Pa., Coal Tech Petrographic Associates, Inc., 55 p.

Deurbrouck, A.S., 1963a, Preparation characteristics of coal from Russell County, Virginia: U.S. Bureau of Mines Report of Investigations 6342, 29 p. [Also available at https://catalog.hathitrust.org/Record/005981100.]

Deurbrouck, A.S., 1963b, Preparation characteristics of coal from Tazewell County, Virginia: U.S. Bureau of Mines Report of Investigations 6297, 29 p. [Also available at https://catalog.hathitrust.org/Record/005981004.]

Deurbrouck, A.S., 1966, Preparation characteristics of coal from Buchanan County, Virginia: U.S. Bureau of Mines Report of Investigations 6740, 49 p. [Also available at https://catalog.hathitrust.org/Record/005980781.]

Diez, M.A., Alvaraez, R., and Barriocanal, C., 2002, Coal for metallurgical coke production-Predictions of coke quality and future requirements for cokemaking: International Journal of Coal Geology, v. 50, nos. 1-4, p. 389-412. [Also available at https://doi.org/10.1016/S01665162(02)00123-4.]

Dobbin, C.E., Owings, C.W., Tryon, F.G., Young, W.H., Snyder, N.H., Plein, L.N., and Osgood, F.D., 1932, Analyses of Montana coals: U.S. Bureau of Mines Technical Paper 529, 129 p., accessed June 1, 2014, at http://babel.hathitrust.org/cgi/pt?id=mdp.39015077559030; view $=1$ up;seq=1.

Donan, J.G., Jr., 1969, Commercial coals and marketing data of the western Kentucky coal field, in Smith, G.E., Williamson, A.D., Ponsetto, L.R., Franklin, G.J., and Palmer, J.E., eds., Middle and Upper Pennsylvanian strata in Hopkins and Webster Counties, Kentucky: Lexington, Ky., Geological Society of Kentucky with Kentucky Geological Survey, Annual Spring Field Conference Guidebook, p. 66-70. 
Dowd, J.J., Turnbull, L.A., Toenges, A.L., Cooper, H.M., Abernethy, R.F., Reynolds, D.A., and Crentz, W.L., 1950a, Estimate of known recoverable reserves of coking coal in Indiana County, Pa.: U.S. Bureau of Mines Report of Investigations 4757, 22 p. [Also available at https://digital.library.unt.edu/ark:/67531/ metadc $38554 / \mathrm{m} 1 / 1 /$.

Dowd, J.J., Turnbull, L.A., Toenges, A.L., Cooper, H.M., Abernethy, R.F., Reynolds, D.A., and Fraser, T., 1950b, Estimate of known recoverable reserves of coking coal in Cambria County, Pa.: U.S. Bureau of Mines Report of Investigations 4734, 25 p. [Also available at https://digital.library.unt.edu/search/?q= Estimate + of + known + recoverable + reserves + of + coking/ + coal + in + Cambria + County $\% 2 \mathrm{C}+$ Pa\&t=fulltext\&sort=.]

Dowd, J.J., Turnbull, L.A., Toenges, A.L., Abernethy, R.F., and Reynolds, D.A., 1951a, Estimate of known recoverable reserves of coking coal in Armstrong County, Pa.: U.S. Bureau of Mines Report of Investigations 4801, 16 p. [Also available at https://digital.library.unt.edu/ark:/67531/ metadc38562/.]

Dowd, J.J., Turnbull, L.A., Toenges, A.L., Abernethy, R.F., and Reynolds, D.A., 1951b, Estimate of known recoverable reserves of coking coal in Fayette County, Pa.: U.S. Bureau of Mines Report of Investigations 4807, 19 p. [Also available at https://digital.library.unt.edu/ark:/67531/ metadc38566/.]

Dowd, J.J., Turnbull, L.A., Toenges, A.L., Abernethy, R.F., and Reynolds, D.A., 1951c, Estimate of known recoverable reserves of coking coal in Floyd County, Ky.: U.S. Bureau of Mines Report of Investigations 4813, 16 p. [Also available at https://digital.library.unt.edu/ark:/67531/ metadc38569/.]

Dowd, J.J., Turnbull, L.A., Toenges, A.L., Abernethy, R.F., and Reynolds, D.A., 1951d, Estimate of known recoverable reserves of coking coal in Pike County, Ky.: U.S. Bureau of Mines Report of Investigations 4792, 34 p. [Also available at https://digital.library.unt.edu/search/? $\mathrm{q}=$ Estimate + of + known + recoverable + reserves + of + coking/ + coal + in + Pike + County $\% 2 \mathrm{C}+$ Ky\&t=fulltext\&sort=.]

Dowd, J.J., Turnbull, L.A., Toenges, A.L., Abernethy, R.F., and Reynolds, D.A., 1951e, Estimate of known recoverable reserves of coking coal in Westmoreland County, Pa.: U.S. Bureau of Mines Report of Investigations 4803, 16 p. [Also available at https://digital.library.unt.edu/ark:/67531/ metadc38563/.]
Dowd, J.J., Toenges, A.L., Abernethy, R.F., and Reynolds, D.A., 1952a, Estimate of known recoverable reserves of coking coal in Jefferson County, Pa.: U.S. Bureau of Mines Report of Investigations 4840, 18 p. [Also available at https://digital.library.unt.edu/search/?q= Estimate + of + Known + Recoverable + Reserves + of + Coking/ + Coal + in + Jefferson + County $\% 2 \mathrm{C}+$ Pa. \&t=fulltext\&sort=.]

Dowd, J.J., Toenges, A.L., Abernethy, R.F., and Reynolds, D.A., 1952b, Estimate of known recoverable reserves of coking coal in Knott County, Ky.: U.S. Bureau of Mines Report of Investigations 4897, 20 p. [Also available at https://digital.library.unt.edu/ark:/67531/metadc38584/.]

Dowd, J.J., Toenges, A.L., Abernethy, R.F., and Reynolds, D.A., 1952c, Estimate of known recoverable reserves of coking coal in Raleigh County, W. Va.: U.S. Bureau of Mines Report of Investigations 4893, 37 p. [Also available at https://digital.library.unt.edu/ark:/67531/metadc38583/.]

Dowd, J.J., Provost, J.M., Travis, R.G., Abernethy, R.F., and Reynolds, D.A., 1955a, Estimate of known recoverable reserves of coking coal in Brooke County, W. Va.: U.S. Bureau of Mines Report of Investigations 5160, 17 p. [Also available at https://digital.library.unt.edu/ark:/67531/ metadc38631/.]

Dowd, J.J., Provost, J.M., Abernethy, R.F., and Reynolds, D.A., 1955b, Estimate of known recoverable reserves of coking coal in Ohio County, W. Va.: U.S. Bureau of Mines Report of Investigations 5171, 14 p. [Also available at https://digital.library.unt.edu/ark:/67531/metadc38632/.]

Dowd, J.J., Provost, J.M., Abernethy, R.F., and Reynolds, D.A., 1956, Estimate of known recoverable reserves of coking coal in Marshall County, W. Va.: U.S. Bureau of Mines Report of Investigations 5207, 21 p. [Also available at https://digital.library.unt.edu/ark:/67531/metadc38636/.]

Dunham, R.J., and Trumbull, J.V.A., 1955, Geology and coal resources of the Henryetta mining district, Okmulgee County, Oklahoma: U.S. Geological Survey Bulletin 1015-F, p. 183-225, accessed October 26, 2016, at https://pubs.usgs.gov/bul/1015f/report.pdf.

Dutcher, L.A.F., and Crelling, J.C., 2000, History of applied coal petrology in the United States; I-Early history of the application of coal petrology in the steel industry: International Journal of Coal Geology, v. 42, nos. 2-3, p. 93-101. [Also available at https://doi.org/10.1016/S01665162(99)00034-8.] 
East, J., 2012, Coal fields of the conterminous United StatesNational Coal Resource Assessment updated version: U.S. Geological Survey Open-File Report 2012-1205, 1 sheet, scale 1:5,000,000, accessed May 17, 2018, at https://doi.org/ $10.3133 /$ ofr20121205.

Eble, C.F., and Weisenfluh, G.A., 2013, Metallurgical coal resources in eastern Kentucky: Kentucky Geological Survey, contract report 57, series 12, 76 p., accessed January 1, 2018, at https://kgs.uky.edu/kgsweb/olops/pub/ kgs/CNR57_12.pdf.

Elston, W.E., 1967, Summary of the mineral resources of Bernalillo, Sandoval, and Santa Fe Counties, New Mexico (exclusive of oil and gas): New Mexico Bureau of Mines and Mineral Resources Bulletin 81, 81 p., 2 pls. [Also available at https:/geoinfo.nmt.edu/publications/monographs/ bulletins/downloads/81/B81.pdf.]

Eveleth, R.W., and Bieberman, R.A., 1983, Mineral and mineral-fuel production activities in New Mexico during 1981: New Mexico Bureau of Mines and Mineral Resources Annual Report, v. 1981-1982, p. 56-64.

ExplorePAHistory.com, 2017a, Coke ovens [steel] historical marker: ExplorePAHistory.com web page, accessed March 29, 2017, at http://explorepahistory.com/ hmarker.php?markerId=1-A-233.

ExplorePAHistory.com, 2017b, Henry Clay Frick [bituminous coal] historical marker: ExplorePAHistory.com web page, accessed March 28, 2017, at http://explorepahistory.com/ hmarker.php? markerId=1-A-2C6.

Fisher, C.A., 1909, Geology of the Great Falls coal field, Montana: U.S. Geological Survey Bulletin 356, 85 p., accessed October 26, 2016, at https://pubs.usgs.gov/bul/ 0356/report.pdf.

Fisher, C.A., and Calvert, W.R., 1914, Geology of the Bering River field and its relations to coal mining conditions, in Report on coal in Alaska for use in United States Navy: House of Representatives Document, no. 876 [63d Congress, 2d session], p. 29-50.

Flint, N.K., 1965, Geology and mineral resources of southern Somerset County, Pennsylvania: Pennsylvania Bureau of Topographic and Geologic Survey, County Report 56A, 267 p., 13 pls., map scale 1:62,500. [Also available at https://ngmdb.usgs.gov/Prodesc/proddesc_32675.htm.]

Fort Smith Times Record, 2014, Heavener coking coal mining project still on hold: Gannett Co. Inc. web page, accessed November 4, 2016, at https:/www.swtimes.com/business/ heavener-coking-coal-mining-project-still-hold.
Gilbride, L., and Ross, T., 2012, Technical Report NI 43-101-New Elk Mine Project, Las Animas County, Colorado U.S.A.: Agapito Associates, Inc., 157 p., accessed February 6, 2014, at http://www.clinemining.com/projects/ coal/new-elk.html.

Gildersleeve, B., 1948, Mineral resources of the Paleozoic area in northwest Georgia, in Butts, C., and Gildersleeve, B., eds., Geology and mineral resources of the Paleozoic area in northwest Georgia: Georgia Department of Mines, Mining, and Geology, Bulletin 54, p. 81-170.

Glenn, L.C., 1912, A geological reconnaissance of the Tradewater River region with special reference to the coal beds (embracing parts of Union, Webster, Hopkins, Crittenden, Caldwell and Christian Counties): Kentucky Geological Survey Bulletin 17, no. 1, 75 p., 2 pls. [Also available at https://kgs.uky.edu/kygeode/services/pubs.]

Goolsby, S.M., Reade, N.S., and Murray, D.K., 1979, Evaluation of coking coals in Colorado: Colorado Geological Survey, Denver, Colo., resource series 7, 72 p., 3 pls., accessed August 21, 2019, at https://store.coloradogeologicalsurvey.org/product/ evaluation-coking-coals-colorado/.

Gloyn, R.W., Tabet, D.E., Tripp, B.T., Bishop, C.E., Morgan, C.D., Gwynn, J.W., and Blackett, R.E., 2003, Energy, mineral, and ground-water resources of Carbon and Emery Counties, Utah: Utah Geological Survey Bulletin 132, 176 p. [Also available at https://catalog.data.gov/dataset/ energy-mineral-and-ground-water-resources-of-carbon-andemery-counties-utah.]

Grandsen, J.F., Jorgensen, J.G., Manery, N., Price, J.T., and Ramey, N.J., 1991, Applications of microscopy to coke making: International Journal of Coal Geology, v. 19, nos. 1-4, p. 77-107. [Also available at https://doi.org/ 10.1016/0166-5162(91)90015-B.]

Gray, T.E., and Boley, C.C., 1958a, Preparation characteristics of coal from Dickenson County, Virginia: U.S. Bureau of Mines Report of Investigations 5405, 28 p.

Gray, T.E., and Boley, C.C., 1958b, Preparation characteristics of coal from Wise County, Virginia: U.S. Bureau of Mines Report of Investigations 5391, 50 p.

Greb, S.F., Eble, C.F., and Hower, J.C., 1999, Depositional history of the Fire Clay coal bed (Late Duckmantian), eastern Kentucky, USA: International Journal of Coal Geology, v. 40, no. 4, p. 255-280. [Also available at https://doi.org/ 10.1016/S0166-5162(99)00004-X.] 
Haley, B.R., 1954, Coal resources of Arkansas: U.S. Geological Survey Bulletin 1072-P, p. 795-831, accessed October 26, 2016, at https://pubs.usgs.gov/bul/1072p/ report.pdf.

Hankinson, F.C., 1965, Petrographic evaluation of coking potential of selected Alaskan coals and blends: The Mineral Industry Research Laboratory of the University of Alaska, Report No. 3, 35 p.

Hendricks, T.A., Knechtel, M.M., Dane, C.H., Rothrock, H.E., and Williams, J.S., 1937, Geology and fuel resources of the southern part of the Oklahoma coal field: U.S. Geological Survey Bulletin 874, 298 p. [Also available at https://pubs.er.usgs.gov/publication/b874.]

Hennen, R.V., and Reger, P.B., 1914, Logan and Mingo Counties: West Virginia Geological and Economic Survey [County Report], 776 p.

Hershey, R.E., Williams, L., and Gandrud, B.W., 1955, Estimate of known recoverable reserves of coking coal in Grundy County, Tenn.: U.S. Bureau of Mines Report of Investigations 5148, 16 p. [Also available at https://digital.library.unt.edu/ark:/67531/metadc38629/.]

Hershey, R.E., Williams, L., Crentz, W.L., and Miller, J.W., 1956a, Estimate of known recoverable reserves and the preparation characteristics of coking coal in Hamilton County, Tenn.: U.S. Bureau of Mines Report of Investigations 5263, 27 p. [Also available at https://digital.library.unt.edu/ark:/67531/metadc38650/.]

Hershey, R.E., Williams, L., Crentz, W.L., and Miller, J.W., 1956b, Estimate of known recoverable reserves and the preparation characteristics of coking coal in Van Buren County, Tenn.: U.S. Bureau of Mines Report of Investigations 5208, 25 p. [Also available at https://digital.library.unt.edu/ark:/67531/metadc38637/.]

Hershey, R.E., Williams, L., Crentz, W.L., Miller, J.W., and Reynolds, D.A., 1956c, Estimate of known recoverable reserves and preparation and carbonizing properties of coking coal in Claiborne County, Tenn.: U.S. Bureau of Mines Report of Investigations 5229, 44 p. [Also available at https:/digital.library.unt.edu/ark:/67531/metadc38641/.]

Hickok, W.O., IV, and Moyer, F.T., 1940, Geology and mineral resources of Fayette County, Pennsylvania: Pennsylvania Topographic and Geologic Survey, County Report 26, 530 p., 3 pls., map scale 1:62,500.

Historic American Engineering Record, 1994, Connellsville coal and coke region, Connellsville vicinity, Fayette [County], Pennsy1vania: National Park Service report, Historic American Engineering Record No. PA-283, 181 p., 13 pls., accessed March 29, 2017, at http://www.loc.gov/ pictures/collection/hh/item/pa2870/.
Hoffman, G.K., 1991, Geology and quality of Menefee Formation coals, Monero coal field, Rio Arriba County, New Mexico: New Mexico Bureau of Mines and Mineral Resources: New Mexico Geology, v. 13, no. 1, 21 p. [Also available at https://nanopdf.com/download/quality-fieldgeology-and_pdf.]

Hoffman, G.K., 1993, Dawson, a town dependent on coal: New Mexico Bureau of Mines and Mineral Resources, v. 5, Lite Geology, 4 p.

Hoffman, G.K., 2017, Energy and mineral resources of New Mexico coal resources: New Mexico Bureau of Geology and Mineral Resources and New Mexico Geological Society, Memoir 50B and Special Publication 138, 80 p. [Also available at https://geoinfo.nmt.edu/publications/ monographs/memoirs/50/B/.]

Hoffman, G.K., and Brister, B.S., 2003, New Mexico's Raton basin coalbed methane play: New Mexico Bureau of Geology and Mineral Resources, New Mexico Geology, v. 25, no. 4, p. 95-110. [Also available at https://www.researchgate.net/publication/242446311_New_ Mexico's_Raton_Basin_coalbed_methane_play.]

Hoffman, G.K., and Hereford, J.P., 2009, Mining history of the Carthage coal field, Socorro County, New Mexico, in Lueth, V., Lucas, S.G., and Chamberlin, R.M., eds., Geology of the Chupadera Mesa: New Mexico Geological Society 60th Fall Field Conference Guidebook, 438 p., accessed November 3, 2016, at https://nmgs.nmt.edu/publications/guidebooks/60.

Hoffman, G.K., and Jones, G.E., 2005, Availability of coal resources in the Vermejo and Raton Formations, Raton coalfield, Raton basin, northeast New Mexico: New Mexico Bureau of Geology and Mineral Resources, OpenFile Report 490, 57 p., accessed December 15, 2017, at https://geoinfo.nmt.edu/publications/openfile/details.cfml? Volume $=490$.

Holway, F., 1975, Getting the handle on metallurgical coal: Coal Age, v. 80 , no. 12 , p. $80-83$.

Hower, J.C., and Pollock, J.D., 1988, Petrology of the Pond Creek coal bed, Eastern Kentucky coalfield: International Journal of Coal Geology, v. 11, nos. 3-4, p. 225-226. [Also available at https://doi.org/10.1016/0166-5162(89)90115-8.]

Hower, J.C., and Pollock, J.D., 1989, Geochemistry of the Pond Creek coal bed in Eastern Kentucky: Organic Geochemistry, v. 12, no. 4, p. 297-302. [Also available at https://doi.org/10.1016/0146-6380(88)90003-4.] 
Hower, J.C., Pollock, J.D., and Griswold, T.B., 1991, Structural controls on the petrology and geochemistry of the Pond Creek coal seam, Pike and Martin Counties, Eastern Kentucky, in Peters, D.C., ed., Geology in coal resource utilization: American Association of Petroleum Geologists, Energy Minerals Division, p. 413-425.

Hower, J.C., Wild, G.D., and Eble, C.F., 1994, Coal quality considerations in the future production of metallurgical coal in eastern Kentucky: Journal of Coal Quality, v. 13, no. 1, p. 1-6.

Hower, J.C., Ruppert, L.F., Eble, C.F., and Clark, W.L., 2005, Geochemistry, petrology, and palynology of the Pond Creek coal bed, northern Pike and southern Martin Counties, Kentucky: International Journal of Coal Geology, v. 62, no. 3, p. 167-181. [Also available at https://doi.org/10.1016/ j.coal.2004.10.003.]

Hower, J.C., Hoffman, G.K., and Garrison, T.M., 2013, Macrinite and funginite forms in Cretaceous Menefee Formation anthracite, Cerrillos coalfield, New Mexico: International Journal of Coal Geology, v. 114, p. 54-59. [Also available at https://doi.org/10.1016/ j.coal.2013.03.007.]

Hutchinson, F.M., 1912, Report on the geology and coals of the Central City, Madisonville, Calhoun, and Newberg quadrangles - In Muhlenberg, Hopkins, Ohio, McLean, Webster, Daviess and Henderson Counties: Kentucky Geological Survey Bulletin 19, serial no. 26, 127 p., 10 pls. [Also available at https://catalog.hathitrust.org/Record/ 011812189.]

Iannacchione, A.T., and Puglio, D.G., 1979, Geology of the lower Kittanning coalbed and related mining and methane emission problems in Cambria County, Pa.: U.S. Bureau of Mines Report of Investigations 8354, 31 p., accessed November 13, 2018, at https://stacks.cdc.gov/view/cdc/ 9273/cdc_9273_DS1.pdf.

International Energy Agency, 2017, Coal information: Overview, 8 p., accessed April 6, 2018, at https:/www.iea.org/publications/freepublications/ publication/CoalInformation2017Overview.pdf.

Jackman, H.W., Eissler, R.L., and Reed, F.H., 1956, Coking coals of Illinois - Their use in blends for metallurgical coke: Illinois State Geological Survey Circular 278, 30 p.

Jackman, H.W., Eissler, R.L., and Helfinstine, R.J., 1959, Coke from medium-volatile and Illinois coals: Illinois State Geological Survey Circular 278, 24 p. [Also available at http://library.isgs.illinois.edu/Pubs/pdfs/circulars/c278.pdf.]

Jackman, H.W., and Helfinstine, R.J., 1967, A survey of the coking properties of Illinois coals: Illinois State Geological Survey Circular 412, 27 p. [Also available at http://library.isgs.illinois.edu/Pubs/pdfs/circulars/c412.pdf.]
Jahanbani, F.R., 1991, 1990 Annual review and forecast of Utah coal production and distribution: State of Utah Natural Resources Division of Energy, $22 \mathrm{p}$.

Jahanbani, F.R., 1994, 1993 Annual review and forecast of Utah coal production and distribution: State of Utah Natural Resources Office of Energy and Resource Planning, 28 p.

Jahanbani, F.R., 1995, 1994 Annual review and forecast of Utah coal production and distribution: State of Utah Natural Resources Office of Energy and Resource Planning, 29 p.

Jahanbani, F.R., 1996, 1995 Annual review and forecast of Utah coal production and distribution: State of Utah Natural Resources Office of Energy and Resource Planning, 43 p.

Jahanbani, F.R., 1997, 1996 Annual review and forecast of Utah coal production and distribution: State of Utah Natural Resources Office of Energy and Resource Planning, 48 p.

Jahanbani, F.R., 1998, 1997 Annual review and forecast of Utah coal production and distribution: State of Utah Natural Resources Office of Energy and Resource Planning, 48 p.

Jahanbani, F.R., 1999, 1998 Annual review and forecast of Utah coal production and distribution: State of Utah Natural Resources Office of Energy and Resource Planning, 38 p.

Jahanbani, F.R., 2000, 1999 Annual review and forecast of Utah coal production and distribution: State of Utah Natural Resources Office of Energy and Resource Planning, 40 p.

Jenkins, O.P., 1924, Geological investigation of the coal fields of Skagit County, Washington: Washington Department of Conservation and Development Bulletin 29, 63 p., 11 pls., accessed July 25, 2019, at https://www.dnr.wa.gov/ publications/ger_b29_geol_coal_fields_skagit_county.pdf.

Johnston, M.N., Hower, J.C., and Rich, R.J., 2014, Notes on the origin of the resinite-rich "pine needle" lithotype of the Cretaceous Cambria coal, Weston County, Wyoming: International Journal of Coal Geology, v. 130, p. 66-69. [Also available at https://doi.org/10.1016/ j.coal.2014.05.008.]

Johnston, M.N., Hower, J.C., Dai, S., Wang, P., Xie, P., and Liu, J., 2015, Petrology and geochemistry of the Harlan, Kellioka, and Darby coals from the Louellen 7.5-minute quadrangle, Harlan County, Kentucky: Minerals (Basel), v. 5, no. 4, p. 894-918, accessed January 7, 2020, at https://doi.org/10.3390/min5040532.

Jones, F.A., 1915, The mineral resources of New Mexico: State School of Mines Mineral Resources Survey of New Mexico, Bulletin 1, 78 p. [Also available at https://geoinfo.nmt.edu/publications/monographs/bulletins/ downloads/1/Bulletin001.pdf.] 
Jones, N.R., Jones, R.W., and Lucke, D.W., 2011, Coal map of Wyoming with energy production and transportation: Wyoming State Geological Survey Map Series 93, 1 sheet, scale 1:500,000, accessed August 1, 2019, at https://www.wsgs.wyo.gov/products/wsgs-2011-ms-93.pdf.

Jordan, P., 2006, Characterising coals for coke production and assessing coke-Predicting coke quality based on coal petrography, rheology and coke petrography: University of the Witwatersrand, Johannesburg, South Africa, M.S. thesis, 111 p. [Also available at http://hdl.handle.net/10539/4761.]

Kaegi, D., and Osterman, C., 1980, The use of Illinois coal for the production of high quality coke: ProceedingsIronmaking Conference, Iron and Steel Society of the American Institute of Mining, Metallurgical and Petroleum Engineering, Inc. [AIME], p. 239-247.

Kelly, C.W., 1970, Coke and coal chemicals-Chapter preprint from minerals yearbook 1969: U.S. Bureau of Mines, $38 \mathrm{p}$.

Kentucky Coal Association and Kentucky Geological Survey, 2011, Kentucky coal facts (11th ed.): Kentucky Coal Association and Kentucky Geological Survey, 42 p., accessed April 26, 2019, at https://eec.ky.gov/Energy/ Coal $\% 20$ Facts $\% 20 \% 20$ Annual\%20Editions/Kentucky $\% 20$ Coal\%20Facts\%20-\%2011th\%20Edition\%20(20092010).pdf.

Kentucky Energy and Environment Cabinet, 2019, Kentucky Q4/2018 coal report-October to December: Kentucky Energy and Environment Cabinet web page, accessed June 3, 2019, at https://eec.ky.gov/Energy/NewsPublications/Quarterly Coal Reports/2018-Q4.pdf.

Kertis, C.A., 1985, Reducing hazards in underground coal mines through the recognition and delineation of coalbed discontinuities caused by ancient channel processes: U.S. Bureau of Mines Report of Investigations 8987, 23 p. [Also available at https://www.cdc.gov/niosh/mining/userfiles/ works/pdfs/ri8987.pdf.]

Knechtel, M.M., 1949, Geology and coal and natural gas resources of north Le Flore County, Oklahoma: Oklahoma Geological Survey Bulletin 68, 76 p. [Also available at http://ogs.ou.edu/docs/bulletins/B68.pdf.]

Kombol, W., 2007, Coal mining in an east Pierce County area known as Pittsburg (1889-1909), Spiketon (1910-1916), and finally Morristown (1917-1927): HistoryLink.org web page accessed January 8, 2020, at https://www.historylink.org/File/8262.
Kramer, R., Pelter, L., Abramowitz, H., Zhou, C., Valia, H., and Hirschi, J., 2008, Suitability of Illinois coal for a multipurpose facility - October 1, 2007, through September 30, 2008: Illinois State Geological Survey, Illinois Clean Coal Institute, Final Technical Report, Project Number 07-1/ER5, 23 p., accessed May 13, 2019, at https://isgs.illinois.edu/icci/reports/07-1KramerER5.pdf.

Kramer, R., Pelter, L., Valia, H., and Ellis, A., 2011, Enhancing coke production energy efficiency while reducing emissions: AISTech 2011 Conference Proceedings, Warrendale, Pa., Association for Iron and Steel Technology, report no. PR-360-135, 12 p., accessed May 13, 2019, at http://digital.library.aist.org/categories/ 2011aistechconferenceproceedings-pr.htm.

Krebs, C.E., and Teets, D.D., Jr., 1914, Kanawha County: West Virginia Geological and Economic Survey [County Report CGR-11], 679 p., 33 pls.

Layden, L., 2014, Eastern Oklahoma coal mining comeback stalls as demand from China Falls: StateImpact Oklahoma web page, accessed November 4, 2016, at https://stateimpact.npr.org/oklahoma/2014/10/23/easternoklahoma-coal-mining-comeback-stalls-along-withdemand-from-china/. [Article date October 23, 2014.]

Lego, B., and Deskins, J., 2017, Coal production in West Virginia; 2017-2040: Morgantown, W. Va., Bureau of Business and Economic Research, West Virginia University College of Business and Economics, 27 p., accessed August 17, 2018, at http://busecon.wvu.edu/bber/pdfs/ BBER-2017-08.pdf.

Lord, N.W., Holmes, J.A., Stanton, F.M., Fieldner, A.C., and Sanford, S., 1913, Analyses of coals in the United States with descriptions of mine and field samples collected between July 1, 1904, and June 30, 1910: U.S. Bureau of Mines Bulletin, v. 22, p. 323-1200. [Also available at https://digital.library.unt.edu/ark:/67531/metadc12240/.]

Lotz, C.W., 1970, Probable original minable extent of the bituminous coal seams of West Virginia: West Virginia Geological and Economic Survey Map 19, 1 pl., scale $1: 4,000,000$.

Lowe, R.W., Crentz, W.L., and Miller, J.W., 1956, Estimate of known recoverable reserves and preparation characteristics of coking coal in Fentress County, Tenn.: U.S. Bureau of Mines Report of Investigations 5235, 34 p. [Also available at https://digital.library.unt.edu/ark:/67531/metadc38646/.] 
Lowenhaupt, D.E., and Gray, R.J., 1980, The alkali-extraction test as a reliable method of detecting oxidized metallurgical coal: International Journal of Coal Geology, v. 1, no. 1, p. 63-73, accessed March 12, 2018, https://doi.org/10.1016/ 0166-5162(80)90006-3.

Luther, E.T., 1959, The coal reserves of Tennessee: Tennessee Department of Conservation and Commerce, Division of Geology, Bulletin 63, 294 p.

Mackowsky, M.-Th., 1977, Prediction methods in coal and coke microscopy: Journal of Microscopy, v. 109, no. 1, p. 119-137. [Also available at https://doi.org/10.1111/ j.1365-2818.1977.tb01121.x.]

Mardirosian, C.A., 1979, Principal mining districts of New Mexico: New Mexico Bureau of Mines and Mineral Resources, New Mexico Geology 1, 3 p. [Also available at https://onlinelibrary.wiley.com/doi/abs/10.1111/j.13652818.1977.tb01121.x.]

Martin, G.C., 1908, Geology and mineral resources of the Controller Bay region, Alaska: U.S. Geological Survey Bulletin 335, 141 p., 8 pls. [Also available at https://pubs.er.usgs.gov/publication/b335.]

Maryland Bureau of Mines, 2017, Ninety-fifth annual report of the Maryland Bureau of Mines-2016: 27 p., accessed May 22, 2019, at https://mde.maryland.gov/programs/LAND/ mining/Pages/BureauofMinesAnnualReports.aspx.

Merritt, R.D., and Hawley, C.C., 1986, Map of Alaska's coal resources: State of Alaska, Department of Natural Resources, Division of Geological and Geophysical Surveys, Special Report 37, 1 sheet, scale 1:2,500,000, accessed February 11, 2014, at http://www.dggs.dnr.state.ak.us/pubs/id/480.

Miller, L.V., 1967, An investigative study of six Indiana coals: Proceedings of the Indiana Academy of Sciences, v. 77, p. 299-304.

Milici, R.C., Freeman, P.A., and Bragg, L.J., 2001a, A digital resource model of the Lower Pennsylvanian Pocahontas no. 3 coal bed, Pottsville Group, central Appalachian basin coal region, chap. $\mathrm{H}$ in Northern and Central Appalachian Basin Coal Regions Assessment Team, eds., 2000 resource assessment of selected coal beds and zones in the northern and central Appalachian basin coal regions: U.S. Geological Survey Professional Paper 1625-C, accessed August 3, 2017, at https://pubs.usgs.gov/pp/p1625c/.
Milici, R.C., Freeman, P.A., Carlton, R.W., Bragg, L.J., Butler, D.T., and Tewalt, S.J., 2001b, Geology and geochemistry of the Middle Pennsylvanian Lower Kittanning coal bed, Allegheny Group, northern Appalachian basin coal region, chap. E in Northern and Central Appalachian Basin Coal Regions Assessment Team, eds., 2000 resource assessment of selected coal beds and zones in the northern and central Appalachian basin coal regions: U.S. Geological Survey Professional Paper 1625-C, accessed August, 3, 2017, at https://pubs.usgs.gov/pp/p1625c/.

Mountjoy, E., 2017, The history of coke: Indiana University of Pennsylvania web page, accessed April 5 2017, at https://www.iup.edu/archives/coal/mining-history/historyof-coke/.

Myers, A.R., and Chenoweth, C., 2008, Directory of coal mines in Illinois 7.5-minute quadrangle series, Sesser quadrangle - Franklin, Jefferson and Perry Counties: Illinois State Geological Survey, 19 p., 1 pl., accessed July 12, 2019, at https://www.isgs.illinois.edu/sites/isgs/files/maps/ coal-maps/topo-mines/sesser.pdf.

Nag, D., Haldar, S.K., Choudhary, P.K., and Banerjee, P.K., 2009, Prediction of coke CSR from ash chemistry of coal blend: International Journal of Coal Preparation and Utilization, v. 29 , no. 5, p. 243-250. [Also available at https://doi.org/10.1080/19392690903218117.]

Newberry, J.S., 1878, Geology of Columbiana County, in Newberry, J.S., Stevenson, J.J., Read, M.C., Wheat, A.W., Orton, E., Hussey, J., Hill, F.C., Lindenmuth, A.C., Hodge, J.T., Andrews, E.B., and Herzer, H., chap. 57 of Report of the Geological Survey of Ohio-Volume III, Geology and palaeontology; Part I, Geology: Ohio Geological Survey, p. 90-132, accessed February 11, 2019, at https://archive.org/details/ReportOfTheGeological SurveyOfOhioVolume3Part1/page/n3.

Northwestern Improvement Company, 1914, [untitled maps of coal mines in the Carbonado-Wilkeson coal field]: Washington State Coal Mine Map Collection, Publications P1-C and P1-D, accessed March 21, 2014, at https://fortress.wa.gov/dnr/geology/?Theme=coalmine.

Oklahoma Department of Mines, 2018, Coal ProgramCoal division mission; and Coal production: Oklahoma Department of Mines web page, accessed March 1, 2018, at http://mines.ok.gov/coal-and-coal-combustion\#production. 
Oklahoma Mining Commission Department of Mines, 2016, Annual Report 2016 - 100th Annual Report calendar year 2016: Oklahoma Mining Commission Department of Mines, 41 p. [Also available at https://mines.ok.gov/annualreports.]

Orton, E., Roy, A., Lord, N.W., Newton, H., McMillan, E., Wright, G.F., Wright, A.A., and Brown, C.N., 1884, Report of the Geological Survey of Ohio-Economic geology: Ohio Geological Survey, v. 5, 1123 p., 8 pl., accessed March 15, 2018, at https://archive.org/stream/ ReportOfTheGeologicalSurveyOfOhioVolume5Part1/ ReportOfGeologicalSurveyOfOhio_v5\#page/n15/mode/ 2up/search/coking.

Ouro Mining, Inc., 2016, Heavener Project: Ouro Mining Inc. web page, accessed November 4, 2016, at http://www.ouromininginc.com/Projects_Heavener.htm.

Palmer, J.E., 1969, Second day of field conference, in Smith, G.E., Williamson, A.D., Ponsetto, L.R., Franklin, G.J., and Palmer, J.E., eds., Middle and Upper Pennsylvanian strata in Hopkins and Webster Counties, Kentucky: Lexington, Ky., Geological Society of Kentucky with Kentucky Geological Survey, Annual Spring Field Conference Guidebook, p. $51-65$.

Pashin, J.C., Carroll, R.E., Barnett, R.L., and Beg, M.A., 1995, Geology and coal resources of the Cahaba coal field: Geological Survey of Alabama Bulletin 163, 49 p., 2 pls.

Patterson, E.D., 1963, Coal resources of Beaver County Pennsylvania, chap. A in Patterson, E.D., ed., Coal resources of western Pennsylvania: U.S. Geological Survey Bulletin 1143, 37 p., 5 pls. [Also available at https://pubs.er.usgs.gov/publication/b1143A.]

Pennsylvania Department of Environmental Protection, 2018, 2017 coal and industrial minerals mining activities; Bituminous coal mining reports - 2017: accessed May 16, 2019, at https://www.dep.pa.gov/Business/Land/Mining/ BureauofMiningPrograms/Reports/Pages/2017-Coal-andIndustrial-Minerals-Mining-Activities.aspx.

Pillmore, C.L., 1991, Geology and coal resources of the Raton coalfield, in Molina, C.L., Jobin, D.A., O’Conner, J.T., and Kottlowski, F.E., eds., Coalfields of New Mexico-Geology and resources: U.S. Geological Survey Bulletin 1972, p. 45-68. [Also available at https://doi.org/10.3133/b1972.]

Pillmore, C.L., Nichols, D.J., and Fleming, R.F., 1999, Field guide to the continental Cretaceous-Tertiary boundary in the Raton basin, Colorado and New Mexico, in Lageson, D.R., Lester, A.P., and Trudgill, B.D., eds., Colorado and adjacent areas: Geological Society of America Field Guide 1, p. 135-155, accessed July 1, 2017, at https://pubs.geoscienceworld.org/books/book/777/ Colorado-and-Adjacent-Areas.
Provost, J.M., Dowd, J.J., Abernethy, R.F., and Reynolds, D.A., 1956, Estimate of known recoverable reserves of coking coal in Marion County, W. Va.: U.S. Bureau of Mines Report of Investigations 5267, 30 p., 9 figs. [Also available at https://digital.library.unt.edu/ark:/67531/metadc38652/.]

Ranger Alaska LLC and Alaska Earth Science, Inc., 2013, Coal exploration permit application for coal leases ADL324600 and ADL229336 Jonesville Coal Mine Project: Ranger Alaska LLC and Alaska Earth Science, Inc., 99 p., accessed May 17, 2018, at http://nr.alaska.gov/ $\mathrm{mlw} / \mathrm{mining} / \mathrm{coal} /$ jonesville/pdf/Jonesville_Exploration $\% 20$ Permit_Application.pdf.

Rao, P.D., 1974, Characterization of Alaska's coals: University of Alaska Mineral Industry Research Laboratory, AR-5, 16 p., accessed March 9, 2018, at https://dggs.alaska.gov/ pubs/series/mirl/ar-report.

Reed, F.H., Jackman, H.W., Rees, O.W., and Henline, P.W., 1952, Some observations on the blending of coals for metallurgical coke: Illinois State Geological Survey, Circular No. 178,8 p. [Also available at https://core.ac.uk/download/pdf/ 10209327.pdf.]

Repine, T.E., Jr., Blake, B.M., Ashton, K.C., Fedorko, N., III, Keiser, A.F., Loud, E.I., Smith, C.J., McClelland, S.W., and McColloch, G.H., 1993, Regional and economic geology of Pennsylvanian age coal beds of West Virginia: International Journal of Coal Geology, v. 23, nos. 1-4, p. 75-101. [Also available at https://doi.org/10.1016/01665162(93)90044-B.]

Rich, F.J., Pish, T.A., and Knell, G.W., 1988, Sedimentology, petrography, and paleoecology of the Cambria coal, Weston County, Wyoming, in Diedrich, R.P., Dyka, M.A.K., and Miller, W.R., eds., Wyoming Geological Association 39th Annual Field Conference Guidebook, Eastern Powder River Basin, Black Hills: Casper, Wyo., Sept. 9-11, 1988, p. 249-261, accessed January 4, 2016, at http://archives.datapages.com/data/wga/data/046/046001/ 249 _wga0460249.htm.

Richards, M., 2013, Exploring history-Youghiogheny River Valley, coke industry intertwined: Trib Total Media [TribLive] web page, accessed March 28, 2017, at https://riblive.com/neighborhoods/yourscottdale/395377574/coke-frick-steel.

Riley, J.T., 2007, Routine coal and coke analysisCollection, interpretation, and use of analytical data: West Conshohocken, Pa., ASTM International, ASTM Manual Series MNL-57, 104 p.

Rothrock, H.E., 1949, Geology and coal resources of the northeast part of the Coosa coal field, St. Clair County, Alabama: Geological Survey of Alabama Bulletin 61, part 1, 163 p., 12 pls. 
Ruppert, L.F., Tewalt, S.J., Wallack, R.N., Bragg, L.J., Brezinski, D.K., Carlton, R.W., Butler, D.T., and Calef, F.J., III, 2001, A digital resource model of the Middle Pennsylvanian Upper Freeport coal bed, Allegheny Group, northern Appalachian basin coal region, chap. D of Northern and Central Appalachian Basin Coal Regions Assessment Team, eds., 2000 resource assessment of selected coal beds and zones in the northern and central Appalachian basin coal regions: U.S. Geological Survey Professional Paper 1625-C, accessed July, 3, 2017, at https://pubs.usgs.gov/ $\mathrm{pp} / \mathrm{p} 1625 \mathrm{c} /$.

Ruppert, L.F., Trippi, M.H., and Slucher, E.R., 2014, Correlation chart of Pennsylvanian rocks in Alabama, Tennessee, Kentucky, Virginia, West Virginia, Ohio, Maryland, and Pennsylvania showing approximate position of coal beds, coal zones, and key stratigraphic units, chap. D. 2 in Ruppert, L.F., and Ryder, R.T., eds., Coal and petroleum resources in the Appalachian basin-Distribution, geologic framework, and geochemical character: U.S. Geological Survey Professional Paper 1708, accessed May 17, 2018, at https://pubs.er.usgs.gov/publication/pp1708.

Schapiro, N., Gray, R.J., and Euser, G.R., 1961, Recent developments in coal petrography: Blast Furnace, Coke Oven and Raw Materials Proceedings, Committee of the Iron and Steel Division, Metallurgical Society of the American Institute of Mining, Metallurgical and Petroleum Engineering, Inc. [AIME], v. 20, p. 89-112.

Schapiro, N., and Gray, R.J., 1964, The use of coal petrography in coke making: Journal of the Institute of Fuel, v. 11, p. 234-242.

Schasse, H.W., Walsh, T.J., and Phillips, W.M., 1984, Addendum to the 1961 edition of Bulletin 47, in Beikman, H.M., Gower, H.D., and Dana, T.A.M., Coal reserves of Washington [Bulletin 47]: Washington Department of Natural Resources, Division of Geology and Earth Resources, 15 p. [Also available at https://www.dnr.wa.gov/ publications/ger_b47_coal_reserves_wa.pdf.]

Schultz, J.E., Eakins, W., Scott, D.C., and Teeters, D.D., 2000, Availability of coal resources in Colorado-Somerset coal field, west-central Colorado: Colorado Geological Survey, Resource Series 38, 84 p. [Also available at https://store.coloradogeologicalsurvey.org/product/coalresources-somerset-field-colorado/.]

Shaffer, B.N., 1992, A depositional model for the Upper Freeport coal bed in eastern Greene County Pennsylvania: M.S. thesis, Morgantown, W. Va., West Virginia University, 121 p., 20 pls.
Sheridan, E.T., 1972, Coke and coal chemicals, in Metals, minerals, and fuels-Minerals Yearbook 1970: U.S. Bureau of Mines, v. 1, p. 423-455. [Also available at http://digital.library.wisc.edu/1711.dl/ EcoNatRes.MinYB1970v1.]

Sheridan, E.T., 1973, Coke and coal chemicals, in Metals, minerals, and fuels-Minerals Yearbook 1971: U.S. Bureau of Mines, v. 1, p. 413-448. [Also available at http://digicoll.library.wisc.edu/cgi-bin/EcoNatRes/ EcoNatRes-idx?id=EcoNatRes.MinYB1971v1.]

Sheridan, E.T., 1974, Coke and coal chemicals, in Metals, minerals, and fuels-Minerals Yearbook 1972: U.S. Bureau of Mines, v. 1, p. 427-460. [Also available at http://digital.library.wisc.edu/1711.dl/ EcoNatRes.MinYB1972v1.]

Sheridan, E.T., 1975, Coke and coal chemicals, in Metals, minerals, and fuels-Minerals Yearbook 1973: U.S. Bureau of Mines, v. 1, p. 413-445. [Also available at http://digital.library.wisc.edu/1711.dl/ EcoNatRes.MinYB1973v1.]

Shotts, R.Q., 1971, Coal reserves of Bibb County, Alabama: Geological Survey of Alabama, Circular 72, 50 p., 4 pls.

Shotts, R.Q., and Riley, H.L., 1966, Coal resources of the Fabius-Flat Rock area, Jackson County, Ala.: U.S. Bureau of Mines, Information Circular 8295, 36 p.

Silverman, A.J., and Harris, W.L., 1967, Stratigraphy and economic geology of the Great Falls-Lewistown Coal Field, central Montana: Montana Bureau of Mines and Geology Bulletin 56, 24 p.

Smith, C.J., and King, H.M., 1982, Beckley coal, contour map, total sulfur [map WV16A]; Coalburg coal, contour map, total sulfur [map WV16B]; Lower Kittanning/5-block coal, contour map, total sulfur [map WV16C]; Pittsburgh coal, contour map, total sulfur [map WV16D]; Pocahontas no. 3 coal, contour map, total sulfur [map WV16E]; and Sewell coal, contour map, total sulfur [map WV16F]: West Virginia Geological and Economic Survey, 6 sheets, scale $1: 2,200,000$.

Southern Railway System, 1972, Coal reserves of Alabama: Washington, D.C., Southern Railway System, 75 p.

Spackman, W., 2000, History of applied coal petrology in the United States, II-A personalized history of the origin and development of applied coal petrology at the Pennsylvania State University: International Journal of Coal Geology, v. 42, nos. 2-3, p. 103-114. [Also available at https://doi.org/10.1016/S0166-5162(99)00035-X.] 
Storrs, A.H., 1910, Report on the Cunningham coal lands and Bering River coal field near Katalla, Kayak district, Alaska, November 1907, in Investigation of the Department of the Interior and of the Bureau of Forestry-Hearings held before the Joint Committee of Congress: Washington, D.C., Government Printing Office, v. 3, p. 2326-2345, accessed at, https://pubs.usgs.gov/bul/0341a/report.pdf.

Stout, W.E., and Lamborn, R.E., 1924, Geology of Columbiana County: Ohio Geological Survey Bulletin 28, 4th series, 408 p., 3 pls. [Also available at https://kb.osu.edu/handle/1811/78502.]

Sundholm, J., Valia, H., Kiessling, F., Richardson, J., Buss, W., Worberg, R., Schwarz, U., Baer, H., Calderon, A., and DiNitto, R., 1999, Manufacture of metallurgical coke and recovery of coal chemicals, chap. 7 in Wakelin, D., ed., The making, shaping and treating of steel, IIronmaking volume: Pittsburgh, Pa., Association for Iron and Steel Technology, p. 381-545, accessed May 14, 2019, at https://cokemaking.wordpress.com/2017/02/24/ manufacture-of-metallurgical-coke-and-recovery-of-coalchemicals/.

Sweet, P.C., 1969, Coking industry in Virginia: Virginia Division of Mineral Resources, Virginia Minerals, v. 15, no. 1, 15 p. [Also available at https://www.dmme.virginia.gov/commercedocs/VAMIN_ VOL15_NO01.pdf.]

Tabet, D., and Wakefield, S., 2006, Coal resource map of Utah: Utah Geological Survey Map 226 DM, 1 pl., scale 1:750,000, accessed August 21, 2019, at https://ugspub.nr.utah.gov/publications/maps/m-226.pdf.

Tavenner, W.H., Dowd, J.J., Abernethy, F.F., and Reynolds, D.A., 1956, Estimate of known recoverable reserves of coking coal in Logan County, W. Va.: U.S. Bureau of Mines Report of Investigations 5259, 50 p., 16 figs. [Also available at https://digital.library.unt.edu/ark:/67531/metadc38649/.]

Tewalt, S.J., Ruppert, L.F., Bragg, L.J., Carlton, R.W., Brezinski, D.K., Wallack, R.N., and Butler, D.T., 2001, A digital resource model of the Upper Pennsylvanian Pittsburgh coal bed, Monongahela Group, northern Appalachian basin coal region, chap. C in Northern and Central Appalachian Basin Coal Regions Assessment Team, eds., 2000 resource assessment of selected coal beds and zones in the northern and central Appalachian Basin coal regions: U.S. Geological Survey Professional Paper 1625-C, accessed April, 7, 2017, at https://pubs.usgs.gov/ $\mathrm{pp} / \mathrm{p} 1625 \mathrm{c}$.

Texas and Oklahoma Coal Company, 2016, [Untitled article]: Texas and Oklahoma Coal Company home page, accessed November 4, 2016, at http://www.texascoal.com/.
Thompson, R.R., 2000, History of applied coal petrology in the United States; III-Contributions to applied coal and coke petrology at the Bethlehem Steel Corporation: International Journal of Coal Geology, v. 42, nos. 2-3, p. 115-128. [Also available at https://doi.org/10.1016/ S0166-5162(99)00036-1.]

Toenges, A.L., Davis, J.D., Turnbull, L.A., and Schopf, J.M., 1945, Reserves, bed characteristics, and coking properties of the Willow Creek coal bed, Kemmerer District, Lincoln County, Wyo.: U.S. Bureau of Mines Technical Paper 673, 48 p., 5 pls. [Also available at https://digital.library.unt.edu/ ark:/67531/metadc66464/.]

Toenges, A.L., and Jolley, T.R., 1949, Investigation of coal deposits in south central Alaska and the Kenai Peninsula: U.S. Bureau of Mines Report of Investigations 4520, 37 p. [Also available at https://dggs.alaska.gov/webpubs/usbm/ri/ text/ri4520.pdf.]

Towsey, P.S., Cameron, I., and Gordon, Y., 2011, Comparison of byproduct and heat-recovery cokemaking technologies: American Coke and Coal Chemicals Institute, 9 p., accessed December 21, 2018, at https://cokemaking.wordpress.com/ 2015/05/06/comparison-of-byproduct-and-heat-recoverycokemaking-technologies/.

Travis, R.G., Dowd, J.J, Abernethy, R.F., and Reynolds, D.A., 1956, Estimate of known recoverable reserves of coking coal in Monongalia County, W. Va.: U.S. Bureau of Mines Report of Investigations 5233, 30 p., 9 figs. [Also available at https://digital.library.unt.edu/ark:/67531/metadc38644/.]

Tremain, C.M., Hornbaker, A.L., Holt, R.D., Murray, D.K., and Ladwig, L.R., 1996, 1995 summary of coal resources in Colorado: Colorado Geological Survey Special Publication 41, 19 p. [Also available at https://store.coloradogeologicalsurvey.org/product/ summary-coal-resources-colorado-1995/.]

Treworgy, C.G., Prussen, E.I., Justice, M.A., Chenoweth, C.A., Bargh, M.H., Jacobson, R.J., and Damberger, H.H., 1997, Illinois coal reserve assessment and database development-Final report: Illinois State Geological Survey, Open File Series 1997-4, 105 p. [Also available at https://doi.org/10.2172/544747.]

Trippi, M.H., Ruppert, L.F., Milici, R.C., and Kinney, S.A., 2014a, Coal and coalbed-methane resources in the Appalachian and Black Warrior basins-Maps showing the distribution of coal fields, coal beds, and coalbed methane fields, chap. D.1 in Ruppert, L.F., and Ryder, R.T., eds., Coal and petroleum resources in the Appalachian basinDistribution, geologic framework, and geochemical character: U.S. Geological Survey Professional Paper 1708, 21 p., accessed May 17, 2018, at https://pubs.usgs.gov/pp/1708/ d1/pdf/pp1708_d1.pdf. 
Trippi, M.H., Kinney, S.A., Gunther, G., Ryder, R.T., and Ruppert, L.F., 2014b, Digital data in support of studies and assessments of coal and petroleum resources in the Appalachian basin, chap. I.1 in Ruppert, L.F., and Ryder, R.T., eds., Coal and petroleum resources in the Appalachian basin-Distribution, geologic framework, and geochemical character: U.S. Geological Survey Professional Paper 1708, 11 p., database files, accessed May 17, 2018, at https://doi.org/10.3133/pp1708I.1.

Trippi, M.H., Ruppert, L.F., Eble, C.F., and Hower, J.C., 2020, Coking coal of the United States-Modern and historical locations of coking coal mining locations and chemical, rheological, petrographic, and other data from modern samples: U.S. Geological Survey data release, accessed October 21, 2020, at https://doi.org/10.5066/P9KFQOKM.

Trumbull, J.V.A., 1957, Coal resources of Oklahoma: U.S. Geological Survey Bulletin 1042-J, p. 307-382. [Also available at https://doi.org/10.3133/b1042J.]

Tuck, R., and Boyd, G., 1966, Plate X-Stratigraphic sections of drill holes A, B, C, D, E, and F, Roslyn-Cle Elum coal field: Washington State Coal Mine Map Collection, Publication KT1_P, 1 sheet, accessed March 21, 2014, at https://fortress.wa.gov/dnr/geology/?Theme=coalmine.

U.S. Bureau of Mines, 1942, Analyses of Illinois coals: U.S. Bureau of Mines Technical Paper 641, 245 p.

U.S. Bureau of Mines, 1967, Coke and coal chemicals: in Metals, minerals, and fuels-Minerals Yearbook 1966: v. 1-2, p. 731-764. [Also available at http://digital.library.wisc.edu/1711.dl/ EcoNatRes.MinYB1966v1and2.]

U.S. Bureau of Mines, 1978, Coke and coal chemicals, in Metals, minerals, and fuels-Minerals Yearbook 1976: v. 1, p. 415-461. [Also available at http://digital.library.wisc.edu/ 1711.dl/EcoNatRes.MinYB1976v1.]

U.S. Energy Information Administration, 2018b, Annual coal report 2017: Washington, D.C., U.S. Energy Information Administration, 64 p., accessed June 5, 2019, at https://www.eia.gov/coal/annual/.

U.S. Energy Information Administration, 2018a, Coal data browser - Quantity \& price of coal imports \& exports data set: U.S. Energy Information Administration web page, accessed April 6, 2018, at https://www.eia.gov/coal/ data/browser/\#/topic/41?agg=2,1,0\&rank=ok\&linechart= COAL.EXPORT_QTY.TOT-TOT-TOT.A\&columnchart= COAL.EXPORT_QTY.TOT-TOT-TOT.A\&map= COAL.EXPORT_QTY.TOT-TOT-TOT.A\&freq=A\&start= $2010 \&$ end $=2017 \&$ ctype $=$ map $\&$ ltype $=$ pin $\&$ rtype $=$ s\&maptype $=0 \&$ rse $=0 \&$ pin $=$.
Utah Geological Survey, Utah Energy Office, 2003, 2001 annual review and forecast of Utah coal-Production and distribution: Utah Geological Survey, Utah Energy Office, 33 p. [includes 6 appendixes, 2 maps]. [Also available at http://geology.utah.gov/utahgeo/energy/coal/pdf/ coalrpt2001.pdf.]

Utah Energy Office, 2003, Annual review and forecast of Utah coal-Production and distribution 2002: Salt Lake City, Utah, Utah Energy Office, 37 p. [Department of Natural Resources].

Utah Energy Office, 2004, Annual review and forecast of Utah coal-Production and distribution 2003: Salt Lake City, Utah, Utah Energy Office, 35 p. [Department of Natural Resources].

Utah Division of Oil, Gas, and Mining, 2015, Public recordsState of Utah, coal mine locations: Salt Lake City, Utah, 1 map sheet, scale 1:195,313, accessed August 20, 2019, at https://fs.ogm.utah.gov/PUB/MINES/Coal_Related/MAPS/ pubrecmap.pdf.

UtahRails.net, 2015, Castle Gate coal mines; Columbia coal mine; Geneva coal mine; Kaiser Coal Company; Kenilworth coal mines and railroads; Kenilworth and Helper railway; and Sunnyside coal mines: accessed June 23, 2015, at https:/utahrails.net/utahcoal/utahcoal-castlegate.php, https://utahrails.net/utahcoal/utahcoal-columbiageneva.php, https://utahrails.net/utahcoal/kaiser-coal.php, https://utahrails.net/utahcoal/utahcoal-kennilworth.php, https://utahrails.net/utahrails/kenilworth-helper.php, and https://utahrails.net/utahcoal/utahcoal-sunnyside.php.

Valentine, G.M., and Huntting, M.T., 1960, Inventory of Washington minerals - Part 1, nonmetallic minerals ( $2 \mathrm{~d}$ ed.): Washington Department of Conservation, Division of Mines and Geology, Bulletin 37, 2 vols., v. 1, 175 p.; v. 2, 1 p., 39 pls., accessed July 25, 2019, at ftp://ww4.dnr.wa.gov/geology/data_downloads/ bulletins/ger_b37_part1_nonmetallic_v1_text.pdf and https://www.dnr.wa.gov/Publications/ger_b37_part1_ nonmetallic_v2_maps.pdf.

Valia, H.S., 1987, Predicting coke strength after reaction with $\mathrm{CO}_{2}$ from coal analysis: Proceedings of the 46th Ironmaking Conference, Iron and Steel Society-American Institute of Mining, Metallurgical and Petroleum Engineers (ISSAIME), Pittsburg, Pa., March 30, 1987, Warrendale, Pa., Iron and Steel Society-American Institute of Mining, p. 78.

Valia, H.S., 1989, Prediction of coke strength after reaction with $\mathrm{CO}_{2}$ from coal analysis at Inland Steel Company: Transactions of the Iron and Steel Society, v. 11, no. 190, p. 55-65. 
Valia, H.S., 1990, Predicting coke strength after reaction with $\mathrm{CO}_{2}$ from coal analysis, in Gray, R.J., and Goscinski, J., eds., Coke reactivity and its effect on blast furnace operation: Iron and Steel Society Publication, p. 109-119.

Valia, H.S., and Mastalerz, M., 2004, Indiana coals and the steel industry: Indiana Geological Survey Special Report $64,28 \mathrm{p}$.

Valia, H.S., 2019, Nonrecovery and heat recovery cokemaking technology, chap. 10 in Suárez-Ruiz, I., Diez, M.A., and Rubiera, F., eds., New trends in coal conversionCombustion, gasification, emissions, and coking:

Cambridge, Mass., Woodhead Publishing, p. 263-292, accessed May 14, 2019, at https://doi.org/10.1016/B978-008-102201-6.00010-8.

Virginia Department of Mines, Minerals, and Energy, 2014, 2014 Virginia Energy Plan, section 6-Coal: Virginia Department of Mines, Minerals, and Energy, 9 p., accessed October 26, 2017, at https://www.dmme.virginia.gov/DE/ 2014_VirginiaEnergyPlan2.shtml.

Virginia Department of Mines, Minerals, and Energy, Division of Geology and Mineral Resources, 2018, Coal production in Virginia: Virginia Department of Mines, Minerals, and Energy web page, accessed July 26, 2018, at https://dmme.virginia.gov/dgmr/coal.shtml.

Walker, C.W., 1980, Geology and energy resources of the Roslyn-Cle Elem area, Kittitas County, Washington: Washington State Department of Natural Resources, Division of Geology and Earth Resources, Open-File Report OF-80-1, 59-p. text, 18 map sheets, scale 1:24,000, plus 1 sheet [ 5 cross sections] and 1 sheet [composite section], accessed July 6, 2020, at https://www.dnr.wa.gov/ publications/ger_ofr80-1_roslyn_cle_elum_coal 24k_pt1.pdf, https://www.dnr.wa.gov/publications/ ger_ofr80-1_roslyn_cle_elum_coal_24k_pt2.pdf, https://www.dnr.wa.gov/publications/ger_ofr80-1_roslyn_ cle_elum_coal_24k_pt3.pdf, https://www.dnr.wa.gov/ publications/ger_ofr80-1_roslyn_cle_elum_coal_ 24k_pt4.pdf, https://www.dnr.wa.gov/publications/ ger_ofr80-1_roslyn_cle_elum_coal_24k_pt5.pdf, https://www.dnr.wa.gov/publications/ger_ofr80-1_roslyn cle_elum_coal_24k_pt6.pdf, and https://www.dnr.wa.gov/ publications/ger_ofr80-1_roslyn_cle_elum_coal_ 24k_pt7.pdf.

Wallace, J.J., Dowd, J.J., Tavenner, W.H., Provost, J.M., Abernethy, R.F., and Reynolds, D.A., 1952, Estimate of known recoverable reserves of coking coal in McDowell County, W.Va.: U.S. Bureau of Mines Report of Investigations 4924, 26 p. [Also available at https://digital.library.unt.edu/ark:/67531/metadc38590/.]
Wallace, J.J., Dowd, J.J., Bowsher, J.A., Abernethy, R.F., and Reynolds, D.A., 1953a, Estimate of known recoverable reserves of coking coal in Somerset County, Pa.: U.S. Bureau of Mines Report of Investigations 4998, 20 p. [Also available at https://digital.library.unt.edu/ark:/67531/ metadc38602/.]

Wallace, J.J., Dowd, J.J., Provost, J.M., Abernethy, R.F., and Reynolds, D.A., 1953b, Estimate of known recoverable reserves of coking coal in Allegheny County, $\mathrm{Pa}$.: U.S. Bureau of Mines Report of Investigations 5003, 16 p. [Also available at https://digital.library.unt.edu/ark:/67531/ metadc38605/.]

Wallace, J.J., Dowd, J.J., Tavenner, W.H., Provost, J.M., Abernethy, R.F., and Reynolds, D.A., 1953c, Estimate of known recoverable reserves of coking coal in Wyoming County, W. Va.: U.S. Bureau of Mines Report of Investigations 4966, 39 p. [Also available at https://digital.library.unt.edu/ark:/67531/metadc38597/.]

Wallace, J.J., Dowd, J.J., Travis, R.G., Abernethy, R.F., and Reynolds, D.A., 1953d, Estimate of known recoverable reserves of coking coal in Letcher County, Ky.: U.S. Bureau of Mines Report of Investigations 5016, 26 p. [Also available at https://digital.library.unt.edu/ark:/67531/ metadc38607/.]

Wallace, J.J., Dowd, J.J., Williams, L., Abernethy, R.F., and Reynolds, D.A., 1953e, Estimate of known recoverable reserves of coking coal in Allegany County, Md.: U.S. Bureau of Mines Report of Investigations 4970, 18 p. [Also available at https://digital.library.unt.edu/ark:/67531/ metadc38598/.]

Wallace, J.J., Dowd, J.J., Tavenner, W.H., Provost, J.M., Abernethy, R.F., and Reynolds, D.A., 1954a, Estimate of known recoverable reserves of coking coal in Mercer County, W. Va.: U.S. Bureau of Mines Report of Investigations 5077, 20 p. [Also available at https://digital.library.unt.edu/ark:/67531/metadc38616/.]

Wallace, J.J., Dowd, J.J., Tavenner, W.H., Provost, J.M., Abernethy, R.F., and Reynolds, D.A., 1954b, Estimate of known recoverable reserves of coking coal in Mingo County, W. Va.: U.S. Bureau of Mines Report of Investigations 5068, 57 p. [Also available at https://digital.library.unt.edu/ark:/67531/metadc38615/.]

Wallace, J.J., Dowd, J.J., Travis, R.G., Abernethy, R.F., and Reynolds, D.A., 1954c, Estimate of known recoverable reserves of coking coal in Harlan County, Ky.: U.S. Bureau of Mines Report of Investigations 5037, 26 p. [Also available at https://digital.library.unt.edu/ark:/67531/ metadc38611/.] 
Wallace, J.J., Dowd, J.J., Travis, R.G., Abernethy, R.F., and Reynolds, D.A., 1954d, Estimate of known recoverable reserves of coking coal in Perry County, Ky.: U.S. Bureau of Mines Report of Investigations 5083, 26 p. [Also available at https://digital.library.unt.edu/ark:/67531/ metadc38617/.]

Wallace, J.J., Dowd, J.J., Provost, J.M., Abernethy, R.F., and Reynolds, D.A., 1955a, Estimate of known recoverable reserves of coking coal in Greene County, Pa.: U.S. Bureau of Mines Report of Investigations 5143, 22 p. [Also available at https://digital.library.unt.edu/ark:/67531/ metadc38626/.]

Wallace, J.J., Dowd, J.J., Provost, J.M., Abernethy, R.F., and Reynolds, D.A., 1955b, Estimate of known recoverable reserves of coking coal in Washington County, Pa.: U.S. Bureau of Mines Report of Investigations 5109, 23 p. [Also available at https://digital.library.unt.edu/ark:/67531/ metadc38620/.]

Walsh, T.J., 1983, Map of coal mine workings in part of King County, Washington: Washington Department of Natural Resources, Division of Geology and Earth Resources, Open-File Report 83-17, 4 p., 1 map sheet, scale 1:24,000, accessed March 9, 2018, at https://www.dnr.wa.gov/ publications/ger_ofr83-17_king_co_coal_mines_24k.pdf.

Ward, W.E., II, 1984, Reserve base of bituminous coal and lignite in Alabama: Geological Survey of Alabama Circular $118,102 \mathrm{p}$.

Warfield, R.S., Landers, W.S., and Boley, C.C., 1966, Sampling and coking studies of coal from the Kukpowruk River area, arctic northwestern Alaska: Bureau of Mines Report of Investigations 6767,58 p. [Also available at https://catalog.hathitrust.org/Record/005950189.]

Warfield, R.S., and Boley, C.C., 1969, Sampling and coking studies of several coalbeds in the Kokolik River, Kukpowruk River, and Cape Beaufort areas of Arctic northwestern Alaska: U.S. Bureau of Mines Report of Investigations 7321, 58 p. [Also available at https://catalog.hathitrust.org/Record/005950189.]

Wells, E.H., 1930, An outline of the mineral resources of New Mexico: New Mexico School of Mines, State Bureau of Mines and Mineral Resources, Circular 1, revised, 15 p. [Also available at https://geoinfo.nmt.edu/publications/ monographs/circulars/1/.]

Westerstrom, L., 1969, Coke and coal chemicals, in Minerals Yearbook 1968-Metals, minerals, and fuels: U.S. Bureau of Mines, v. 1-2, p. 411-448. [Also available at http://digital.library.wisc.edu/1711.dl/ EcoNatRes.MinYB1968v1and2.]
West Virginia Geological and Economic Survey, 1980a, Generalized sulfur content of the bituminous coals of West Virginia: West Virginia Geological and Economic Survey Map WV1, 1 sheet, scale 1:2,000,000. [Also available at https://statesurveys.americangeosciences.org/vufind/Record/ 1987049936/Details.]

West Virginia Geological and Economic Survey, 1980b, Generalized BTU heating value of the bituminous coals of West Virginia: West Virginia Geological and Economic Survey Map WV-3, 1 sheet, scale 1:2,000,000. [Also available at https://statesurveys.americangeosciences.org/vufind/ Record/1987049932.]

West Virginia Geological and Economic Survey, 1980c, Generalized ash content of the bituminous coals of West Virginia: West Virginia Geological and Economic Survey Map WV-4, 1 sheet, scale 1:2,000,000. [Also available at https://statesurveys.americangeosciences.org/vufind/Record/ 1987049935.]

West Virginia Geological and Economic Survey, 1980d, Coal rank of the bituminous coals of West Virginia: West Virginia Geological and Economic Survey Map WV-8, 1 sheet, scale 1:2,000,000. [Also available at https://statesurveys.americangeosciences.org/vufind/Record/ 1987049933.]

West Virginia Office of Miners' Health, Safety and Training, 2018, Statistical report and directory of mines: Charleston, W. Va., West Virginia Office of Miners' Health, Safety and Training, 217 p., accessed May 20, 2019, at http://www.wvminesafety.org/PDFs/FY\%202017\%20 Annual\%20Report.pdf.

White, I.C., 1891, Stratigraphy of the bituminous coal field of Pennsylvania, Ohio, and West Virginia: U.S. Geological Survey Bulletin 65, 212 p., 11 pls. [Also available at https://doi.org/10.3133/b65.]

Williams, L., and Hershey, R.E., 1956, Estimate of known recoverable reserves of coking coal in Bledsoe County, Tenn.: U.S. Bureau of Mines Report of Investigations 5234, 18 p. [Also available at https://digital.library.unt.edu/ark:/ 67531/metadc38645/.]

Williams, L., Lowe, L.A., Turnbull, L.A., Carman, E.P., Crentz, W.L., Reynolds, D.A., and Abernethy, R.G., 1954, Estimate of known recoverable reserves and the preparation and carbonizing properties of coking coal in Putnam County, Tenn.: U.S. Bureau of Mines Report of Investigations 5029, 21 p. [Also available at https://catalog.hathitrust.org/Record/005949902.] 
Williams, L., Abernethy, R.F., Gandrud, B.W., Reynolds, D.A., and Wolfson, D.E., 1955a, Estimate of known recoverable reserves and the preparation and carbonizing properties of coking coal in Overton County, Tenn.: U.S. Bureau of Mines Report of Investigations 5131, 27 p. [Also available at https://digital.library.unt.edu/ark:/67531/metadc38623/.]

Williams, L., Hershey, R.E., Abernethy, R.F., Gandrud, B.W., and Reynolds, D.A., 1955b, Estimate of known recoverable reserves and the preparation and carbonizing properties of coking coal in Sequatchie County, Tenn.: U.S. Bureau of Mines Report of Investigations 5136, 28 p. [Also available at https://digital.library.unt.edu/ark:/67531/metadc38625/.]

Williams, L., Hershey, R.E., and Gandrud, B.W., 1955c, Estimate of known recoverable reserves and the preparation and carbonizing properties of coking coal in Marion County, Tenn.: U.S. Bureau of Mines Report of Investigations 5159, 30 p. [Also available at https://digital.library.unt.edu/ark:/ 67531/metadc38630/m2/1/high_res_d/metadc38630.pdf.]

Williams, L., James, C., Gandrud, B.W., and Reynolds, D.A., 1955d, Estimate of known recoverable reserves and the preparation characteristics of coking coal in Anderson County, Tenn.: U.S. Bureau of Mines Report of Investigations 5185, 52 p. [Also available at https://digital.library.unt.edu/ark:/67531/metadc38634/.]

Williams, L., Gibbs, H.K., Crentz, W.L., and Miller, J.W., 1956a, Estimate of known recoverable reserves and preparation characteristics of coking coal in Scott County, Tenn.: U.S. Bureau of Mines Report of Investigations 5232, 36 p. [Also available at https://digital.library.unt.edu/ark:/67531/ metadc38643/.]

Williams, L., Gibbs, H.K., Crentz, W.L., Miller, J.W., and Reynolds, D.A., 1956b, Estimate of known recoverable reserves and preparation and carbonizing properties of coking coal in Campbell County, Tenn.: U.S. Bureau of Mines Report of Investigations 5258, 78 p. [Also available at https://digital.library.unt.edu/ark:/67531/metadc38648/.]
Williams, L., James, C., Crentz, W.L., and Miller, J.W., 1956c, Estimate of known recoverable reserves and the preparation characteristics of coking coal in Morgan County, Tenn.: U.S. Bureau of Mines Report of Investigations 5266, 43 p. [Also available at https://digital.library.unt.edu/ark:/67531/ metadc38651/.]

Williams, R.Y., 1914, Mining conditions in the Bering River field, Alaska, as a result of the field examination of the United States Navy Alaskan coal investigating expedition, in Report on coal in Alaska for use in United States Navy: House of Representatives Document 876, 63d Congress, 2d Session, Washington, D.C., p. 12-28.

Winston, R.B., 1990, Preliminary report on coal quality trends in Upper Pottsville Formation coal groups and their relationships to coal resource development, coalbed methane occurrence, and geologic history in the Warrior coal basin, Alabama: Geological Survey of Alabama Circular $152,53 \mathrm{p}$.

World Coal Association, 2018, How is steel produced?: World Coal Association web page, accessed April 18, 2018, at https://www.worldcoal.org/coal/uses-coal/how-steelproduced.

Wright, C.E., and Stucker, J.D., comps., 2018, 2017 report on Ohio mineral industries - An annual summary of the State's economic geology: Columbus, Ohio, Ohio Department of Natural Resources, Division of Geological Survey, 23 p., 1 pl., accessed May 23, 2019, at http://geosurvey.ohiodnr.gov/economic-geology/previousreports-on-mineral-industries.

Zimmerman, R.E., 1979, Evaluating and testing the coking properties of coal-A world coal book: San Francisco, Calif., Miller Freeman Publications, Inc., 144 p. 


\section{Appendix 1. Information About Coking Coal Deposits in the United States}

Table 1.1 contains data and information about coking coal deposits in the United States. Data and information provided in table 1.1 include: location number; State; county; coal basin; coal field; coal region, district, or area; coal beds or coal zones; formations; groups; ages; coking characteristics; ranks; mines; company; location description; nearby towns, rivers, mountains, township and range, and section; current activity; years of past activity; and references. The Excel workbook file containing table 1.1 is available at https://doi.org/10.3133/ ofr20201113. 


\section{Appendix 2. Location Data for Coal Samples Analyzed for this Report and Coal Sample Data Shared by Mining Companies}

Table 2.1 contains location data for coal samples analyzed for this report and coal sample data shared by mining companies. Coal sample location data provided in table 2.1 include: State; field identification of the sample (FieldID); county; sampling date (SampDate); decimal longitude and latitude (DecLong and DecLat, respectively); group or formation (GpFm); coal bed, split, and (or) part of bed (BedSplit); mine name and (or) company name (MineComp); mine type (MineType; surface or underground); method of collection
(CollMeth, channel or grab); thickness of bed, in inches (ThickInch); coal field or coal region name (CoalFldReg); system or series name (SystSer); stage or age name (StageAge); and Comments. The Excel workbook file containing table 2.1 is available at https://doi.org/10.3133/ofr20201113. Trippi and others (2020) (USGS data release) is the official record of this data, which has been reproduced here for reader convenience. The data release can be accessed at https://doi.org/10.5066/ P9KFQOKM. 


\section{Appendix 3. Proximate and Ultimate Analysis Data for Coal Samples Analyzed for This Report and Coal Sample Data Shared by Coal Mining Companies}

Table 3.1 contains the proximate and ultimate analysis data for coal samples analyzed for this report and coal sample data shared by coal mining companies. Coal sample data provided in table 3.1 include: State, field identification of the sample, basis on which data are reported (Basis), percentages mass ratios of air-dry loss (ADL\%), residual moisture (RM\%), moisture (Moist\%), ash (Ash\%), volatile matter (VM\%), fixed carbon $(\mathrm{FC} \%)$, hydrogen $(\mathrm{H} \%)$, carbon $(\mathrm{C} \%)$, nitrogen $(\mathrm{N} \%)$, sulfur $(\mathrm{S} \%)$, oxygen $(\mathrm{O} \%)$, calorific value (CVBtuPerLb), sulfate sulfur (SulfS\%), pyritic sulfur (PyrS\%), organic sulfur (OrgS\%), equilibrium moisture (EQM\%), true specific gravity (TSG; unitless), and Rank (calculated using volatile matter [VM] and calorific value [CV] as described in ASTM method D388). The Excel workbook file containing table 3.1 is available at https://doi.org/10.3133/ofr20201113. Trippi and others (2020) (USGS data release) is the official record of this data, which has been reproduced here for reader convenience. The data release can be accessed at https://doi.org/10.5066/ P9KFQOKM.

\section{Pennsylvania data}

Twelve of the 13 Pennsylvania samples included ash, VM, FC, and sulfur data on a dry basis, but the Upper Kittanning sample from Somerset County, Pennsylvania, only had a VM value. Only one of the Pennsylvania samples (Upper Kittanning from Indiana County) had a moisture content (4.56 percent); the remaining 12 samples came from cores that were never tested for moisture. The company's anonymous representative (written commun., 2016) suggested that we assume a moisture value of 6 percent, which he considered average for these coals. Using 6 percent moisture, we calculated ash, VM, FC, and sulfur values on an as-received (ar) basis; VM, FC, and sulfur on a dry-ash-free (daf) basis; and VM and FC on a dry-mineral-matter-free (dmmf) basis. Seven of the 12 Pennsylvania samples had CVs reported on a dry basis; for these seven samples we calculated CVs on ar, daf, and mmmf bases. For the remaining five samples (not counting the "Upper Kittanning Somerset County" sample) we assumed CVs greater than $14,000 \mathrm{Btu} / \mathrm{lb}$ because $\mathrm{CVs}$ for the other seven samples were greater than 14,000 Btu/lb, and because three of the five samples had VM percentages less than 31 percent, putting them into the medium- to low-volatile bituminous ranges where $\mathrm{CVs}$ are supposed to be greater than $14,000 \mathrm{Btu} / \mathrm{lb}$. It is possible that the two samples with VM percentages greater than 31 percent (the Upper Freeport Indiana County and Lower Kittanning Elk County samples) could have CVs less than $13,000 \mathrm{Btu} / \mathrm{lb}$ and greater than or equal to $11,500 \mathrm{Btu} / \mathrm{lb}$, making them high-volatile $\mathrm{B}$ or $\mathrm{C}$ bituminous instead of high-volatile A bituminous (as shown in table 3.1). Without CVs, we were unable to determine the true rank of these samples. Only one Pennsylvania sample (Upper Kittanning, Indiana County) had values for hydrogen $(\mathrm{H})$, carbon $(\mathrm{C})$, nitrogen $(\mathrm{N})$, and oxygen $(\mathrm{O})$ (on a dry basis); we calculated the ar and daf bases values for these elements shown in table 3.1 .

\section{ArcelorMittal data}

Moisture, ash, VM, FC, H, C, N, S, O, pyritic S, organic $\mathrm{S}$, sulfate $\mathrm{S}, \mathrm{EQM}$, and $\mathrm{CV}$ data (all reported on a dry basis except moisture and EQM) were provided for all 40 ArcelorMittal samples that are included in table 3.1. We calculated the data shown on ar, daf, dmmf, and mmmf bases. The sample for Bed 11A-3 had an unusually low CV $(13,655$, a mmmf), which is in the range for high-volatile $\mathrm{B}$ bituminous coal, but the VM value was only 21.67 percent (dmmf), which is in the range for low-volatile bituminous coal. We classified the sample as a low-volatile coal despite the low CV because all other ArcelorMittal coals from the same mine were also lowvolatile bituminous coals.

\section{Corky's Carbon Consultancy data}

Moisture, ash, sulfur, VM, and CV data (all reported on a dry basis except moisture) were provided for all 22 Corky's Carbon Consultancy samples included in table 3.1. Fourteen of the 22 samples (excluding WVBoone2, WVKanawha, WVLogan2, WVNicholas1, WVRaleigh1, VATazewell, VAWise 3, and VAWise4) had data for H, C, N, and O (dry basis). We calculated FC (dry), and values for all parameters listed above (where possible) on ar and daf bases. We also calculated (where possible) VM and FC on a dmmf basis, and $\mathrm{CV}$ on a mmmf basis. 


\section{Appendix 4. Major Element Data for Ash Samples Analyzed for This Report and Ash Sample Data Shared by Mining Companies}

Table 4.1 contains major element data from ash samples that were analyzed for this report and ash sample data that were shared by mining companies. Ash sample data provided in table 4.1 include: State; field identification of the sample (FieldID); percentage mass ratios of $\mathrm{Al}, \mathrm{Ca}, \mathrm{Fe}, \mathrm{K}, \mathrm{Mg}, \mathrm{Na}$, $\mathrm{P}, \mathrm{S}, \mathrm{Si}, \mathrm{Ti}, \mathrm{Sr}, \mathrm{Ba}$, and $\mathrm{Mn}$ in the ash; percentages of $\mathrm{Al}_{2} \mathrm{O}_{3}$, $\mathrm{CaO}, \mathrm{Fe}_{2} \mathrm{O}_{3}, \mathrm{~K}_{2} \mathrm{O}, \mathrm{MgO}, \mathrm{Na}_{2} \mathrm{O}, \mathrm{P}_{2} \mathrm{O}_{5}, \mathrm{SO}_{3}, \mathrm{SiO}_{2}, \mathrm{TiO}_{2}, \mathrm{SrO}$, $\mathrm{BaO}$, and $\mathrm{Mn}_{3} \mathrm{O}_{4}$ in the ash; acid/base ratio (ABRatio, unitless); alkali index (AlkIndex, unitless); and predicted (or calculated) coke strength after reaction with $\mathrm{CO}_{2}$ (pCSR). Major element oxide percentages in the ash for $\mathrm{Al}_{2} \mathrm{O}_{3}, \mathrm{CaO}$, $\mathrm{Fe}_{2} \mathrm{O}_{3}, \mathrm{~K}_{2} \mathrm{O}, \mathrm{MgO}, \mathrm{Na}_{2} \mathrm{O}, \mathrm{P}_{2} \mathrm{O}_{5}, \mathrm{SO}_{3}, \mathrm{SiO}_{2}$, and $\mathrm{TiO}_{2}$ were provided for 13 Pennsylvania samples, 40 ArcelorMittal samples, and 22 Corky's samples. We converted these reported major oxide percentages into elemental percentages which are also included in table 4.1. Major element oxide percentages in the ash for $\mathrm{SrO}, \mathrm{BaO}$, and $\mathrm{Mn}_{3} \mathrm{O}_{4}$ were provided for all 40 ArcelorMittal samples and these were also converted into elemental percentages and reported in table 4.1. The Excel workbook file containing table 4.1 is available at https://doi.org/ 10.3133/ofr20201113. Trippi and others (2020) (USGS data release) is the official record of this data, which has been reproduced here for reader convenience. The data release can be accessed at https://doi.org/10.5066/P9KFQOKM. 


\section{Appendix 5. Minor and Trace Element Data for Coal Samples Analyzed for This Report and Coal Sample Data Shared by Mining Companies}

Table 5.1 contains minor and trace element data from coal samples analyzed for this report and coal sample data shared by mining companies. Sample data provided in table 5.1 include: State; field identification of the sample (FieldID); percentage mass ratios of $\mathrm{Cl}$ and $\mathrm{F}$; parts per million (ppm) mass ratios of $\mathrm{As}, \mathrm{B}, \mathrm{Ba}, \mathrm{Be}, \mathrm{Bi}, \mathrm{Cd}, \mathrm{Ce}, \mathrm{Co}, \mathrm{Cr}$, Cs, Cu, Dy, Er, Eu, Ga, Gd, Ge, Hg, Hf, Ho, In, La, Li, Mn,
Mo, Nb, Nd, Ni, Pb, Pr, Rb, Sb, Se, Sm, Sn, Sr, Ta, Tb, Te, Th, Tl, Tm, U, V, W, Y, Yb, and Zn. The Excel workbook file containing table 5.1 is available at https://doi.org/10.3133/ ofr20201113. Trippi and others (2020) (USGS data release) is the official record of this data, which has been reproduced here for reader convenience. The data release can be accessed at https://doi.org/10.5066/P9KFQOKM. 


\section{Appendix 6. Rheological Data for Coal Samples Analyzed for This Report and Coal Sample Data Shared by Mining Companies}

Table 6.1 contains rheological data for coal samples analyzed for this report and coal sample data shared by mining companies. Coal sample data provided in table 6.1 include: State, field identification of the sample (FieldID), Free-Swelling Index (FSI), maximum fluidity in dial divisions per minute (MxFldDdpm), maximum fluidity temperature (MxFldTmpC), softening temperature (SftTmpC), solidification temperature (SolTmpC), plastic range (PlstRngC), maximum percentage of contraction (MaxCont\%), maximum percentage of dilatation (MaxDil\%), initial softening temperature $\mathrm{T} 1$ (T1 InSoftC), initial dilatation temperature T2 (T2InDilatC), dilatation temperature T3 (T3DilatC), and percentage of dilatation (Dilatatn\%). The Excel workbook file containing table 6.1 available at https://doi.org/10.3133/ ofr20201113. Trippi and others (2020) (USGS data release) is the official record of this data, which has been reproduced here for reader convenience. The data release can be accessed at https://doi.org/10.5066/P9KFQOKM. 


\section{Appendix 7. Petrography Data for Coal Samples Analyzed for This Report and Coal Sample Data Shared by Mining Companies}

Table 7.1 contains petrography data for coal samples analyzed for this report and coal sample data shared by mining companies. Petrography data provided in table 7.1 include: State; field identification of the sample (FieldID); coal rank based on VM\% and CV\% per ASTM D388 (Rank); mean maximum percentage of vitrinite reflectance in oil (Mean $\mathrm{R}_{\mathrm{o}}$ max); coal rank based on mean $\mathrm{R}_{\mathrm{o}} \max$ per Davis (1978) ( $\mathrm{R}_{\mathrm{o}}$ maxRank); percentage volume ratios of totals of vitrinite (TotVitrin \%), semifusinite (TotSemfus\%), inertinite (TotInert \%), liptinite (TotLiptin $\%$ ), mineral matter (TotMinMat $\%$ ), and inerts (TotInerts\%); Compositional Balance Index
(CBI); Stability Index (SI); and predicted (or calculated) Coke Stability Factor (pCSF). Note that coal rank based on mean $\mathrm{R}_{\mathrm{o}}$ max may not be the same as coal rank based on VM and $\mathrm{CV}$ as shown in tables 3.1 to 5.1. CBI, SI, and pCSF values were not provided for the ArcelorMittal samples. The Excel workbook file containing table 7.1 is available at https://doi.org/ 10.3133/ofr20201113. Trippi and others (2020) (USGS data release) is the official record of this data, which has been reproduced here for reader convenience. The data release can be accessed at https://doi.org/10.5066/P9KFQOKM. 


\section{Appendix 8. Miscellaneous Test Data for Coal Samples Shared by Mining Companies}

Table 8.1 contains miscellaneous test data for coal samples shared by mining companies. The data provided in table 8.1 include: State, field identification of the sample (FieldID), percentage of coal oxidation (Oxidatn $\%$ ), Hardgrove Grindability Index (HGI), ash-fusion (in a reducing environment) initial deformation temperature (AshFusIT-F), ash-fusion softening temperature (AshFusST-F), ash-fusion hemispherical temperature (AshFusHT-F), and ash-fusion fluid temperature (AshFusFT-F). The Excel workbook file containing table 8.1 is available at https://doi.org/10.3133/ ofr20201113. Trippi and others (2020) (USGS data release) is the official record of this data, which has been reproduced here for reader convenience. The data release can be accessed at https://doi.org/10.5066/P9KFQOKM. 


\section{Appendix 9A. Thermal and (or) Coking Coal Production and the Number of Coal Mines by State, County, and Mine Type in 2017}

Table 9A.1 contains the thermal and (or) coking coal production and the number of coal mines by State, county, and mine type in 2017. Data in table 9A.1 are from U.S.

Energy Information Administration (2018b): “Annual Coal
Report 2017" (table 2, at https://www.eia.gov/coal/annual/pdf/ table2.pdf). The Excel workbook file containing table 9A.1 is available at https://doi.org/10.3133/ofr20201113. 


\section{Appendix 9B. Disposition of Thermal and (or) Coking Coal Beds by} State in 2017

Table 9B. 1 contains the disposition of thermal and (or) coking coal beds by State and metallurgical or nonmetallurgical use in 2017. Data in table 9B.1 are from U.S. Energy Information Administration (2018b): “Annual Coal
Report 2017" (table 8, at https:/www.eia.gov/coal/annual/pdf/ table2.pdf). The Excel workbook file containing table $9 \mathrm{~B} .1$ is available at https://doi.org/10.3133/ofr20201113. 


\section{Appendix 9C. Production and Bed Thickness of Several Major Thermal and (or) Coking Coal Beds by Mine Type in 2017}

Table 9C.1 contains the production and bed thickness of several major thermal and (or) coking coal beds by mine type in 2017. Data in table 9C.1 are from U.S. Energy Information Administration (2018b): “Annual Coal Report 2017” (table 5, at https://www.eia.gov/coal/annual/pdf/table2.pdf). The Excel workbook file containing table $9 \mathrm{C} .1$ is available at https://doi.org/10.3133/ofr20201113. 


\section{Appendix 10A. Production of Thermal and (or) Coking Coal in Western} Kentucky by County in 2018

Table 10A.1 contains the production of thermal and (or) coking coal in Western Kentucky by county in 2018. Data in table 10A.1 are from Kentucky Energy and Environment Cabinet (2019): "Kentucky Q4/2018 Coal Report"
(https://eec.ky.gov/Energy/News-Publications/Quarterly Coal Reports/2018-Q4.pdf). The Excel workbook file containing table 10A.1 is available at https://doi.org/10.3133/ ofr20201113. 


\section{Appendix 10B. Production of Thermal and (or) Coking Coal in Western Kentucky by Mine Type in 2018}

Table 10B.1 contains the production of thermal and (or) coking coal in Western Kentucky by mine type in 2018. Data in table 10B.1 are from Kentucky Energy and Environment Cabinet (2019): "Kentucky Q4/2018 Coal Report"
(https://eec.ky.gov/Energy/News-Publications/Quarterly Coal Reports/2018-Q4.pdf). The Excel workbook file containing table 10B.1 is available at https://doi.org/10.3133/ ofr20201113. 


\section{Appendix 11A. Production of Bituminous Thermal and (or) Coking Coal in Pennsylvania by Coal Bed and County in 2017}

Table 11A.1 contains the production of bituminous thermal and (or) coking coal in Pennsylvania by coal bed and county in 2017. Data and information in table 11A.1 are from Pennsylvania Department of Environmental Protection (2018): "2017 Coal and Industrial Minerals Mining Activities; Bituminous Coal Mining Reports
- 2017' (https://www.dep.pa.gov/Business/Land/Mining/ BureauofMiningPrograms/Reports/Pages/2017-Coal-andIndustrial-Minerals-Mining-Activities.aspx). The Excel workbook file containing table 11A.1 is available at https://doi.org/ $10.3133 /$ ofr20201113. 


\section{Appendix 11B. Number of Bituminous Thermal and (or) Coking Coal Mines in Pennsylvania by Coal Bed and County in 2017}

Table 11B.1 contains the number of bituminous thermal and (or) coking coal mines in Pennsylvania by coal bed and county in 2017. Data and information in table 11B.1 are from the Pennsylvania Department of Environmental Protection (2018): "2017 Coal and Industrial Minerals Mining Activities; Bituminous Coal Mining Reports
- 2017' (https://www.dep.pa.gov/Business/Land/Mining/ BureauofMiningPrograms/Reports/Pages/2017-Coal-andIndustrial-Minerals-Mining-Activities.aspx). The Excel workbook file containing table 11B.1 is available at https://doi.org/ 10.3133/ofr20201113. 


\section{Appendix 11C. Underground Production of Bituminous Thermal and (or) Coking Coal in Pennsylvania by Coal Bed and County in 2017}

Table 11C.1 contains the underground production of bituminous thermal and (or) coking coal in Pennsylvania by coal bed and county in 2017. Data and information in table 11C.1 are from the Pennsylvania Department of Environmental Protection (2018): “2017 Coal and Industrial Minerals Mining Activities; Bituminous Coal Mining Reports
- 2017" (https://www.dep.pa.gov/Business/Land/Mining/ BureauofMiningPrograms/Reports/Pages/2017-Coal-andIndustrial-Minerals-Mining-Activities.aspx). The Excel workbook file containing table 11C.1 is available at https://doi.org/ $10.3133 /$ ofr20201113. 


\section{Appendix 11D. Number of Underground Bituminous Thermal and (or) Coking Coal Mines in Pennsylvania by Coal Bed and County in 2017}

Table 11D.1 contains the number of underground bituminous thermal and (or) coking coal mines in Pennsylvania by coal bed and county in 2017. Data and information in table 11D.1 are from the Pennsylvania Department of Environmental Protection (2018): "2017 Coal and Industrial Minerals Mining Activities; Bituminous Coal Mining Reports
- 2017" (https://www.dep.pa.gov/Business/Land/Mining/ BureauofMiningPrograms/Reports/Pages/2017-Coal-andIndustrial-Minerals-Mining-Activities.aspx). The Excel workbook file containing table 11D.1 is available at https://doi.org/ 10.3133/ofr20201113. 


\section{Appendix 11E. Surface Production of Bituminous Thermal and (or) Coking Coal in Pennsylvania by Coal Bed and County in 2017}

Table 11E. 1 contains the surface production of bituminous thermal and (or) coking coal in Pennsylvania by coal bed and county in 2017. Data and information in table 11E.1 are from Pennsylvania Department of Environmental Protection (2018): “2017 Coal and Industrial Minerals Mining Activities; Bituminous Coal Mining Reports
- 2017' (https://www.dep.pa.gov/Business/Land/Mining/ BureauofMiningPrograms/Reports/Pages/2017-Coal-andIndustrial-Minerals-Mining-Activities.aspx). The Excel workbook file containing table 11E.1 is available at https://doi.org/ 10.3133/ofr20201113. 


\section{Appendix 11F. Number of Surface Bituminous Thermal and (or) Coking Coal Mines in Pennsylvania by Coal Bed and County in 2017}

Table 11F.1 contains the number of surface bituminous thermal and (or) coking coal mines in Pennsylvania by coal bed and county in 2017. Data and information in table 11F.1 are from the Pennsylvania Department of Environmental Protection (2018): "2017 Coal and Industrial Minerals Mining Activities; Bituminous Coal Mining Reports
- 2017' (https://www.dep.pa.gov/Business/Land/Mining/ BureauofMiningPrograms/Reports/Pages/2017-Coal-andIndustrial-Minerals-Mining-Activities.aspx). The Excel workbook file containing table 11F.1 is available at https://doi.org/ 10.3133/ofr20201113. 


\section{Appendix 12. Production of Thermal and (or) Coking Coal in Ohio by County} and Coal Bed in 2017

Table 12.1 contains the production of thermal and (or) coking coal in Ohio by county and coal bed in 2017. Data in table 12.1 are from Wright and Stucker (2018): "2017 Report on Ohio Mineral Industries: An Annual Summary of the
State's Economic Geology" (http://geosurvey.ohiodnr.gov/ economic-geology/previous-reports-on-mineral-industries). The Excel workbook file containing table 12.1 is available at https://doi.org/10.3133/ofr20201113. 


\section{Appendix 13A. Production of Thermal and (or) Coking Coal in Maryland by Coal Bed and County in 2016}

Table 13A.1 contains the production of thermal and (or) coking coal in Maryland by coal bed and county in 2016. Data in table 13A.1 are from Maryland Bureau of Mines (2017):

"Ninety-Fifth Annual Report of the Maryland Bureau of Mines
2016" (https://mde.maryland.gov/programs/LAND/mining/ Pages/BureauofMinesAnnualReports.aspx). The Excel workbook file containing table 13A.1 is available at https://doi.org/ 10.3133/ofr20201113. 


\section{Appendix 13B. Number of Thermal and (or) Coking Coal Mines in Maryland by Coal Bed and County in 2016}

Table 13B. 1 contains the number of thermal and (or) coking coal mines in Maryland by coal bed and county in 2016. Data in table 13B.1 are from Maryland Bureau of Mines (2017): "Ninety-Fifth Annual Report of the Maryland
Bureau of Mines 2016" (https://mde.maryland.gov/programs/ LAND/mining/Pages/BureauofMinesAnnualReports.aspx). The Excel workbook file containing table 13B.1 is available at https://doi.org/10.3133/ofr20201113. 


\section{Appendix 13C. Production from Underground and Surface Coal Mines in Maryland by County, Coal Bed, Operator, and Mine Permit Number in 2016}

Table 13C.1 contains the production from underground and surface coal mines in Maryland by county, coal bed, operator, and mine permit number in 2016. Data in table 13C.1 are from Maryland Bureau of Mines (2017): "Ninety-Fifth Annual Report of the Maryland Bureau of Mines 2016"
(https://mde.maryland.gov/programs/LAND/mining/Pages/ BureauofMinesAnnualReports.aspx). The Excel workbook file containing table 13C.1 is available at https://doi.org/10.3133/ ofr20201113. 


\section{Appendix 14A. Production of Thermal and (or) Coking Coal in West Virginia by Coal Bed and County in 2017}

Table 14A.1 contains the production of thermal and (or) coking coal in West Virginia by coal bed and county in 2017. Data in table 14A.1 are from West Virginia Office of Miners' Health, Safety and Training (2018): "2017 Statistical Report and Directory of Mines" (https://minesafety.wv.gov/PDFs/ CY\%202017\%20Annual\%20Report.pdf). The Excel workbook file containing table 14A.1 is available at https://doi.org/ 10.3133/ofr20201113. 


\section{Appendix 14B. Number of Thermal and (or) Coking Coal Mines in West Virginia by Coal Bed and County in 2017}

Table 14B.1 contains the number of thermal and (or) coking coal mines in West Virginia by coal bed and county in 2017. Data in table 14B.1 are from West Virginia Office of Miners' Health, Safety and Training (2018): “2017 Statistical
Report and Directory of Mines" (https://minesafety.wv.gov/ PDFs/CY\%202017\%20Annual\%20Report.pdf). The Excel workbook file containing table 14B.1 is available at https://doi.org/10.3133/ofr20201113. 


\section{Appendix 15A. Original Coal Resources in Eastern Kentucky, by Bed}

Table 15A.1 contains information on the original coal resources in eastern Kentucky, by bed. Data in table 15A.1 are from Eble and Weisenfluh (2013): "Metallurgical Coal Resources in Eastern Kentucky” (https://kgs.uky.edu/kgsweb/
olops/pub/kgs/CNR57_12.pdf). The Excel workbook file containing table 15A.1 is available at https://doi.org/10.3133/ ofr20201113. 


\section{Appendix 15B. Remaining Coal Resources in Eastern Kentucky in 2012, by Bed}

Table 15B.1 contains information on the remaining coal resources in eastern Kentucky in 2012, by bed. Data in table 15B.1 are from Eble and Weisenfluh (2013): "Metallurgical Coal Resources in Eastern Kentucky"
(https://kgs.uky.edu/kgsweb/olops/pub/kgs/CNR57_12.pdf). The Excel workbook file containing table 15B.1 is available at https://doi.org/10.3133/ofr20201113. 


\section{Appendix 15C. Percentage of Original Coal Resources Remaining in Eastern Kentucky in 2012}

Table 15C. 1 contains information on the percentage of original coal resources remaining in eastern Kentucky in 2012. Data in table 15C.1 are from Eble and Weisenfluh (2013): "Metallurgical Coal Resources in Eastern Kentucky"
(https://kgs.uky.edu/kgsweb/olops/pub/kgs/CNR57_12.pdf). The Excel workbook file containing table 15C.1 is available at https://doi.org/10.3133/ofr20201113. 


\section{Appendix 16A. Production of Thermal and (or) Coking Coal in Eastern Kentucky by County in 2018}

Table 16A.1 contains the production of thermal and (or) coking coal in eastern Kentucky by county in 2018. Data in table 16A.1 are from Kentucky Energy and Environment Cabinet (2019): "Kentucky Q4/2018 Coal Report"
(https://eec.ky.gov/Energy/News-Publications/Quarterly Coal Reports/2018-Q4.pdf). The Excel workbook file containing table 16A.1 is available at https://doi.org/10.3133/ ofr20201113. 


\section{Appendix 16B. Production of Thermal and (or) Coking Coal in Eastern Kentucky by Mine Type in 2018}

Table 16B.1 contains the production of thermal and (or) coking coal in Eastern Kentucky by mine type in 2018. Data in table 16B.1 are from Kentucky Energy and Environment Cabinet (2019): "Kentucky Q4/2018 Coal Report"
(https://eec.ky.gov/Energy/News-Publications/Quarterly Coal Reports/2018-Q4.pdf). The Excel workbook file containing table 16B.1 is available at https://doi.org/10.3133/ ofr20201113. 


\section{Appendix 17A. Production of Thermal and (or) Coking Coal in Alabama by County and Mine Type During Fiscal Year 2017 (October 2016 to September 2017)}

Table 17A.1 contains the production of thermal and (or) coking coal in Alabama by county and mine type during fiscal year 2017 (October 2016 to September 2017). Data in table 17A.1 are from Alabama Department of Labor Office of Mine Safety and Inspection (2017): "Quarterly Fiscal Year 2017 Coal Reports” (https://labor.alabama.gov/ inspections/mining/docs/MR_1st_QTR_2017.pdf,
https://labor.alabama.gov/inspections/mining/docs/MR_2nd QTR_2017.pdf, https://labor.alabama.gov/inspections/mining/ docs/MR_3rd_QTR_2017.pdf, and https://labor.alabama.gov/ inspections/mining/docs/MR_4th_QTR_2017.pdf). The Excel workbook file containing table 17A.1 is available at https://doi.org/10.3133/ofr20201113. 


\section{Appendix 17B. Number of Thermal and (or) Coking Coal Mines in Alabama by County and Mine Type During Fiscal Year 2017 (October 2016 to September 2017)}

Table 17B.1 contains the number of thermal and (or) coking coal mines in Alabama by county and mine type during fiscal year 2017 (October 2016 to September 2017). Data in table 17B.1 are from Alabama Department of Labor Office of Mine Safety and Inspection (2017): “Quarterly Fiscal Year 2017 Coal Reports" (https://labor.alabama.gov/ inspections/mining/docs/MR_1st_QTR_2017.pdf,
https://labor.alabama.gov/inspections/mining/docs/MR_2nd QTR_2017.pdf, https://labor.alabama.gov/inspections/mining/ docs/MR_3rd_QTR_2017.pdf, and https://labor.alabama.gov/ inspections/mining/docs/MR_4th_QTR_2017.pdf). The Excel workbook file containing table $17 \mathrm{~B} .1$ is available at https://doi.org/10.3133/ofr20201113. 


\section{Appendix 18. Historical Details of Pittsburgh Coal Bed Mining in the Connellsville and Klondike Coke Districts of Fayette County, Pennsylvania}

The Pittsburgh coal bed was extensively mined in the late 19th and early 20th centuries in the "Connellsville coke district" which is about 42-miles long and averages 3.5-miles wide between Smithfield and Latrobe, Pennsylvania (Historic American Engineering Record, 1994; Tewalt and others, 2001). The northeast-trending coal basin exists where the Uniontown and Latrobe synclines lie between the Chestnut Ridge anticline to the southeast and the Fayette anticline to the northwest (Historic American Engineering Record, 1994). Low ash yield, and low sulfur and phosphorus contents made the Pittsburgh coal in the Connellsville district very attractive for coking. Coal from the Pittsburgh bed in other locations (for example, along the Monongahela River in the city of Pittsburgh) was often higher in sulfur content and (or) yielded soft coke that was unable to support the weight of iron ore and limestone in a blast furnace (Historic American Engineering Record, 1994).

The Connellsville district was America's most important and productive coking coal area in the late 19th and early 20th centuries. Starting in 1841, beehive ovens in the Youghiogheny River valley in Fayette County, Pennsylvania, began converting bituminous coal from the Pittsburgh coal bed into coke for use in steel industry blast furnaces (Hickok and Moyer, 1940; Historic American Engineering Record, 1994; ExplorePAHistory.com, 2017a). However, Connellsville coke produced in the 1840s and 1850s was not used in Pittsburgh blast furnaces; instead it was shipped to blast furnaces in Cincinnati and other cities outside of western Pennsylvania (Hickok and Moyer, 1940; Historic American Engineering Record, 1994). By 1855, there were 26 coke ovens in the Connellsville district, and about 80 more in Pittsburgh, but the Pittsburgh ovens only produced fuel for forges and foundries, not for blast furnaces. In 1856, there were 21 blast furnaces in Pennsylvania and 3 in Maryland using coke, but none were in the Connellsville district and none used Connellsville coal.

The Graff, Bennett \& Company blast furnace, the first in Pittsburgh, began using coke from the Connellsville district in 1859 (Historic American Engineering Record, 1994). Soon, Connellsville coke was being used in many locations in western Pennsylvania. By 1870, there were 550 to 790 beehive ovens in the Connellsville district (sources vary), and 7 blast furnaces in Pittsburgh that consumed about one-third of the coke produced by the Connellsville ovens.

In 1871, Henry Clay Frick started the H.C. Frick Coke Company which soon dominated the coke industry in the Connellsville district, becoming the major supplier of coke to the Carnegie Steel Company in Pittsburgh (Historic American Engineering Record, 1994; Richards, 2013; ExplorePAHistory. com, 2017b). During the mid-1870s, many coke makers in the Connellsville district failed due to a rapid drop in coke prices during the "Panic of 1873." Frick purchased a large number of these failing companies at bargain prices. In 1883, Andrew Carnegie and his associates became majority stockholders of the H.C. Frick Coke Company, and Frick joined the management of Carnegie Steel. However, Frick and Carnegie disagreed over the rough treatment of striking miners in 1887 and 1892, and eventually Frick was forced out in 1900 (Historic American Engineering Record, 1994; ExplorePAHistory. com, 2017b). One year later Carnegie Steel and H.C. Frick Coke were purchased by John Pierpont Morgan and merged into U.S. Steel (Historic American Engineering Record, 1994; Richards, 2013).

In 1880, the U.S. Census listed three major steel manufacturing companies with more than 1000 employees in western Pennsylvania: the Cambria Iron Company of Johnstown, Pennsylvania; and Carnegie Steel and Jones \& Laughlin, both in Pittsburgh. There were 7,211 ovens in the Connellsville district in 1880, with another 731 ovens under construction (Hickok and Moyer, 1940; Historic American Engineering Record, 1994). Over three million short tons (mst) of Connellsville coal was mined, from which $2.2 \mathrm{mst}$ of coke was produced. That same year, in the United States, there were about 13,500 coke ovens that used 5.2 mst of coal to produce about 3.3 mst of coke (Historic American Engineering Record, 1994). Coking businesses existed in 13 States and territories in 1880, Pennsylvania having the most, with 124 . The State of Pennsylvania produced $2.8 \mathrm{mst}$ of coke, with the Connellsville region producing 79 percent of the State's total and 67 percent of the Nation's total.

During the 1880s and 1890s, about 75 percent of Pennsylvania coke was made in the Connellsville district, with a peak of 87.6 percent in 1895 (Historic American Engineering Record, 1994). In 1890, there were 15,865 ovens in the Connellsville district producing 6,464,156 short tons of coke (Hickok and Moyer, 1940). During the 19th century, Pennsylvania produced over half of all coke produced in the United States, but in 1900 Pennsylvania produced only 49.5 percent of U.S. coke (Historic American Engineering Record, 1994). There were 20,981 ovens producing $10,021,000$ tons of coke in the Connellsville district in 1900 (Hickok and Moyer, 1940).

In the 1880s and 1890s, supplies of the Pittsburgh coal in the Connellsville district began to be exhausted (Historic American Engineering Record, 1994). In addition, there was very little property available for purchase because most had already been purchased by H.C. Frick Coke Company and other companies. As a result, in the late 1890s several companies began investigating deposits of Pittsburgh coking coal in an area just west of the Uniontown Syncline known as the Klondike (or Lower Connellsville) district. The American 
Coke Company, the Eureka Fuel Company (later called the South West Connellsville Coke Company), the Washington Coal and Coke Company, and the W.J. Rainey Company began mining in the Klondike district starting in 1899.

Klondike coke was denser than Connellsville coke, which was a desirable trait for new larger blast furnaces that needed dense coke to support greater weights of ore and limestone. In 1900 , there were 2,033 ovens in the Klondike district producing 385,909 short tons of coke (Hickok and Moyer, 1940). The number of ovens increased annually until 1917 when it peaked at 16,420 . Peak coke production from the Klondike district was 9,580,215 short tons in 1916. From that point, coke production decreased until 1932 when only 225,594 short tons were produced. The number of beehive ovens hit bottom in 1935 with only 2,576 ovens (Hickok and Moyer, 1940).

By the start of the 20th century, many smaller steel companies had been bought and merged into companies headed by Andrew Carnegie, J.P. Morgan, or W.H. Moore (Historic American Engineering Record, 1994).

Coke production in the Connellsville district peaked in 1907 at 13,089,427 short tons (Hickok and Moyer, 1940). The number of beehive ovens in the district peaked in 1910 with 24,481 . The number of beehive ovens then declined (except for a brief resurgence during World War I) as the by-product oven became the preferred method of coke making. The only by-product battery in the Connellsville district was the SemetSolvay plant at Dunbar, built in 1896 (Hickok and Moyer, 1940). In the early 1900s, H.C. Frick built a large by-product recovery coke plant at Clairton, Pennsylvania, to replace his beehive ovens in the Connellsville district (Richards, 2013). The Clairton Coke Works was still in operation in 2013, but at a much-reduced level after production declines in the 1980s and 1990s. Other by-product recovery batteries were also built in Pittsburgh, Aliquippa, and Midland, Pennsylvania, and Youngstown, Ohio (ExplorePAHistory.com, 2017a). The number of beehive ovens in the Connellsville district decreased to only 2,983 in 1937 (Hickok and Moyer, 1940). Production of coke bottomed out in 1932 with only 90,900 short tons of coke produced.

Between 1942 and 1965 the U.S. Bureau of Mines (USBM) published records of the amount of coal received for manufacturing oven-coke in the United States by fields of origin including the Central Pennsylvania, Connellsville, Freeport, Pittsburgh, Somerset, Washington, and Westmoreland districts in Pennsylvania (Buch and others, 1943; De Carlo and others, 1945, 1946, 1947, 1948, 1949, 1950, 1951, 1953, 1954, 1955, 1956, 1958a, 1958b, 1958c, 1959a, 1959b, 1960, 1961, 1962, 1963; De Carlo and Sheridan, 1964, 1965, 1967). During that time, the Connellsville district went from being the highest producing field in Pennsylvania with $17 \mathrm{mst}$ in 1942 to the second highest producing field at $6 \mathrm{mst}$ in 1965 (appendix 20 and fig. 18.1). The Pittsburgh district rose from $13 \mathrm{mst}$ in 1942 to 16 mst in 1965, passing the Connellsville district in 1956.

From 1966 through 1976 the USBM published the amount of coal received at oven-coke plants in the United States by producing counties (U.S. Bureau of Mines, 1967, 1978; De Carlo and Watson, 1968; Westerstrom, 1969; Kelly, 1970; Sheridan, 1972, 1973, 1974, 1975; Cooper, 1975, 1976). Washington and Greene Counties remained the first and second most productive counties, respectively, throughout this 11-year period (appendix 21 and fig. 18.2). Allegheny

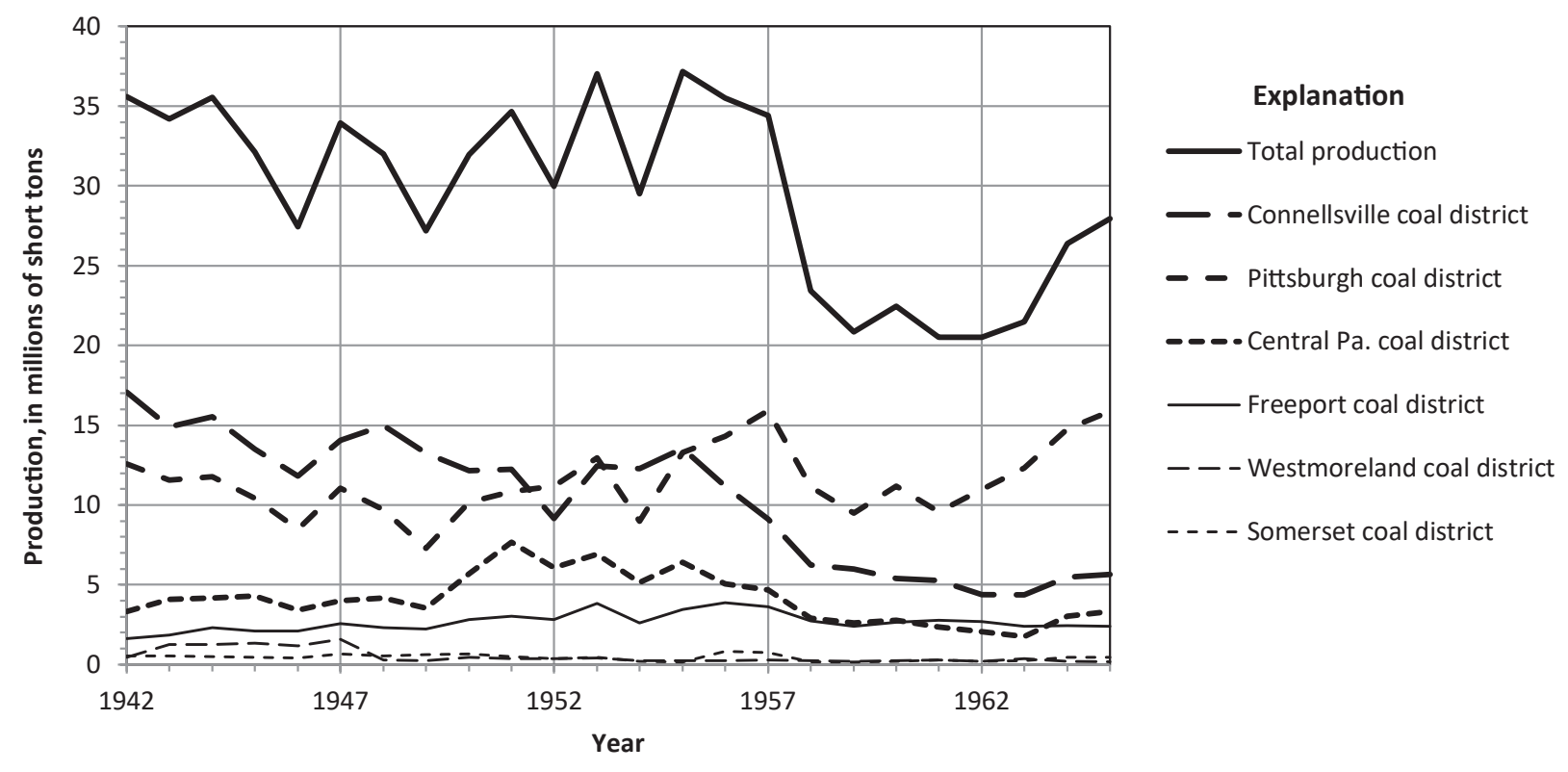

Figure 18.1. Chart showing the coal purchased for manufacturing oven-coke in Pennsylvania by fields of origin from 1942 to 1965. Abbreviation: Pa., Pennsylvania. 


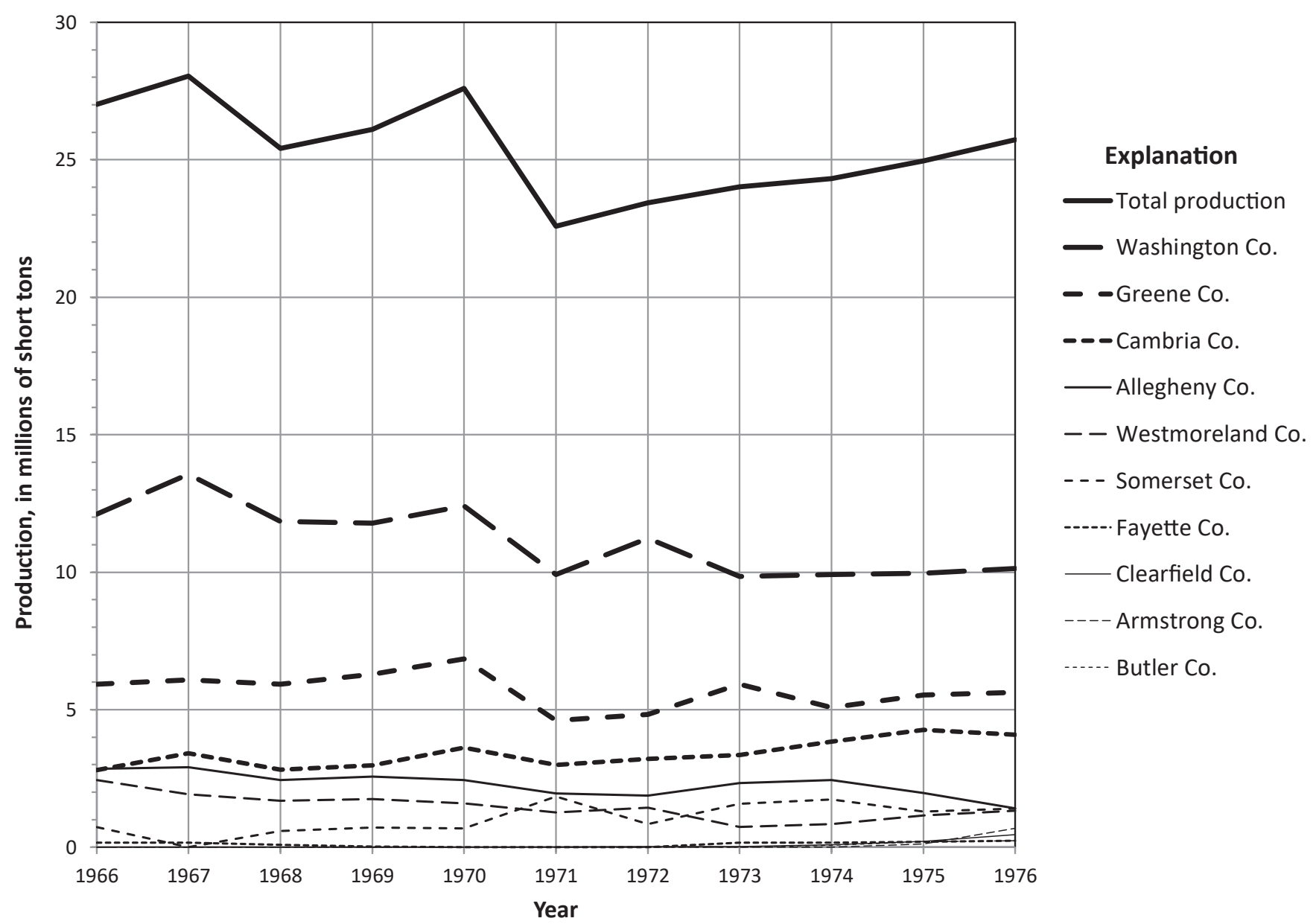

Figure 18.2. Chart showing the origin of coal received by oven-coke plants in Pennsylvania by producing county from 1966 to 1976. Abbreviation: Co., County.

and Cambria Counties started off as the third and fourth most productive counties, respectively, but within the first year they swapped positions, and remained fourth and third, respectively, from 1967 through 1976. Westmoreland was the fifth most productive county from 1966 through 1970, and again in 1972. Somerset County was sixth in 1966, and from
1968 to 1970, but in 1971 and from 1973 to 1976 Somerset County surpassed Westmoreland County to become the fifth most productive county. Fayette County, long past its boom years, remained in last place every year, except in 1967 when Somerset produced only 1,000 short tons. 


\section{Appendix 19. Historical Details of Lower Freeport Coal-Bed Mining in Indiana, Jefferson, and Fayette Counties, Pennsylvania}

In 1884, the Rochester and Pittsburgh Coal and Iron Company built 356 beehive ovens to coke Lower Freeport coal in the newly created company town of Walston in Jefferson County, Pennsylvania, near Punxsutawney (Mountjoy, 2017). By 1887 , they had increased the number of ovens to 500 , and then added another 550 ovens and a second new company town called Adrian a few miles northeast of Walston. Finally, in 1889 they built even more ovens and a third company town called Eleanora a few miles north of Adrian. Coke from these three towns was sold mostly to foundries in cities along the Mississippi River and the Great Lakes, including Chicago. In the 1890s and 1900s, Rochester and Pittsburgh Coal and Iron Company built two blast furnaces at Punxsutawney and DuBois, Pennsylvania, that used local coke to make pig iron. The furnaces remained profitable for many years, but during the early 20th century Rochester and Pittsburgh began moving their operations out of Jefferson County, and by 1935 the blast furnaces had become obsolete and were scrapped.

Other companies also began coking Jefferson County coal including Bell, Lewis and Yates Mining Company, which operated the Big Soldier mine with 100 beehive ovens in the town of Soldier just south of Reynoldsville, Pennsylvania, and Cascade Coal and Coke Company with another 100 ovens in Sykesville, Pennsylvania (Mountjoy, 2017). The Big Soldier mine was taken over by Rochester and Pittsburgh in 1904. Cascade Coal and Coke's business boomed in the 1900s, and they added another 300 ovens in Sykesville, Pennsylvania, but in the 1910s their business went into decline and they ceased operations before the end of World War I. No commercial coking has occurred in Jefferson County since then.

In Indiana County, Pennsylvania, nine miles west of the town of Indiana, George Mikesell began a small coking operation with 12 beehive ovens in 1887 (Mountjoy, 2017). After several ownership changes, the operation was increased to 202 ovens and a new company town, Graceton, was built. Because of the large number of partings, the coal had to be cleaned to improve coke quality. In 1900, Youngstown Steel Company bought the mine and ovens and used the coke for their steel-making operation as well as selling it to customers in New Jersey, New England, and local foundries. In 1920, the plant was sold again to New York businessman Warren Delano. Coke prices fluctuated in the 1920s and early 1930s, and the plant went bankrupt in 1936. It was purchased by local businessman Abe Light of Punxsutawney. Business did not improve until World War II when the demand for coke increased, but after the war the business went into a slump again, and in 1953 the company shut its doors for good.

A second coking operation in Indiana County run by the Indiana Coal and Coke Company was begun in 1890 a short distance south of Graceton (Mountjoy, 2017). The company town, originally named Oklahoma, later changed to Coral, ramped up to 300 beehive ovens in 1903.

In 1904, Rochester and Pittsburgh Coal and Iron Company started a new plant with (eventually) 278 beehive ovens in the town of Ernest, about six miles north of Indiana, Pennsylvania (Mountjoy, 2017). Between 1921 and 1924 the ovens were shut down as orders dropped, but in the late 1920s demand rose, reaching a peak in 1929. Demand dropped once again during early 1930s and the ovens were shut down in 1936 until World War II when demand for coke increased and the ovens were restarted again. Coke production reached a peak in 1945, but by the early 1960s the ovens were shut down again for good.

In 1952, Rochester and Pittsburgh Coal and Iron Company built another battery of beehive ovens in Lucerne, Pennsylvania, about five miles south of Indiana, Pennsylvania, to help supply the steel industry with coke at a time when the supply of coke to furnaces was often insufficient (Mountjoy, 2017). In 1957, the operation was sold to Shenango, Inc., who ran the ovens until 1972 when they were shut down permanently, ending the coking industry in Indiana County. 


\section{Appendix 20. Coal Purchased for Manufacturing of Coke in Pennsylvania by Coal Districts of Origin, From 1942 to 1965}

Table 20.1 contains information on the coal purchased for manufacturing oven-coke in Pennsylvania by coal districts of origin from 1942 to 1965. Data in table 20.1 are from U.S. Bureau of Mines Mineral Yearbooks for 1942 to 1965 (Buch and others, 1943; De Carlo and others, 1945, 1946, 1947, 1948, 1949, 1950, 1951, 1953, 1954, 1955, 1956, 1958a, 1958b, 1958c, 1959a, 1959b, 1960, 1961, 1962, 1963;
De Carlo and Sheridan, 1964, 1965, 1967). The Excel workbook file containing table 20.1 is available at https://doi.org/ 10.3133/ofr20201113. Trippi and others (2020) (USGS data release) is the official record of this data, which has been reproduced here for reader convenience. The data release can be accessed at https://doi.org/10.5066/P9KFQOKM. 


\section{Appendix 21. Origin of Coal Received by Oven-Coke Plants in Pennsylvania by Producing County, From 1966 to 1976}

Table 21.1 contains the origin of coal received by ovencoke plants in Pennsylvania by producing county from 1966 to 1976. Data in table 21.1 are from U.S. Bureau of Mines Mineral Yearbooks for 1966 to 1976 (U.S. Bureau of Mines, 1967, 1978; De Carlo and Watson, 1968; Westerstrom, 1969; Kelly, 1970; Sheridan, 1972, 1973, 1974, 1975; Cooper,
1975, 1976). The Excel workbook file containing table 21.1 is available at https://doi.org/10.3133/ofr20201113. Trippi and others (2020) (USGS data release) is the official record of this data, which has been reproduced here for reader convenience. The data release can be accessed at https://doi.org/10.5066/ P9KFQOKM. 

